\title{
Laís Fajersztajn
}

Relações entre meio ambiente urbano e qualidade de vida:

Um estudo a partir do caso da poluição do ar

Tese apresentada à Faculdade de Medicina da

Universidade de São Paulo, para obtenção do

título de Doutor em Ciências

Programa de Fisiopatologia Experimental

Orientador: Prof. Dr. Paulo Hilário Nascimento Saldiva

São Paulo 
Dados Internacionais de Catalogação na Publicação (CIP)

Preparada pela Biblioteca da

Faculdade de Medicina da Universidade de São Paulo

Creprodução autorizada pelo autor

Fajersztajn, Laís

Relações entre meio ambiente urbano e qualidade de vida : um estudo a partir do caso da poluição do ar / Laís Fajersztajn. -- São Paulo, 2016.

Tese(doutorado)--Faculdade de Medicina da Universidade de São Paulo. Programa de Fisiopatologia Experimental.

Orientador: Paulo Hilário Nascimento Saldiva.

Descritores: 1.Cidades 2.Cidade saudável 3.Metrópoles 4.Saúde da população urbana 5.Qualidade de vida 6.Poluição do ar 7.Monitoramento ambiental 8.Neoplasias pulmonares 9.Saúde Pública 
Aos meus país sempre,

e também à minha querida cidade natal que aprendi a amar profundamente. 



\section{AGRADECIMENTOS}

Agradeço em primeiro àquele que me abriu as portas deste vasto campo de pesquisa e me mostrou como o humor pode instigar a ciência e como a ciência pode instigar a vida. Prof. Paulo Saldiva, obrigada pelo acolhimento, oportunidades, ensinamentos, exemplo inspirador e por tantas descobertas difíceis de serem expressas em palavras.

Agradeço sinceramente à casa que me recebeu. Ser aluna da Faculdade de Medicina da Universidade de São Paulo, foi um cartão de visitas que me propiciou orgulho e oportunidades maravilhosas. À esta escola minha eterna gratidão.

Agradeço também ao Instituto Saúde e Sustentabilidade e à sua diretora, Evangelina Vormittag, pois foi lá que o sonho e as oportunidades para realizar este estudo surgiram.

Agradeço aos professores e colegas de disciplina que participaram da minha formação e aos professores que fizeram parte da Banca Julgadora do Exame de Qualificação pelas valiosas contribuições. Em especial, agradeço aos professores Francisco Chiaravalloti e Tatiana Toporcov, ambos da Faculdade de Saúde Pública, por terem me convidado para ser monitora de suas disciplinas, uma experiência valiosa para minha formação em epidemiologia.

Agradeço especialmente aos colegas que contribuíram para a árdua e prazerosa tarefa de publicar os artigos desenvolvidos ao longo desta pós-graduação. Assim, agradeço novamente ao Prof. Paulo e também à Micheline de S. Z. S. Coelho, Nilmara de O. Alves e à Natália de S. X. Costa. Agradeço especialmente à Ligia Vizeu Barrozo, pela contribuição com a visão da geografia, pelo auxílio na execução dos mapas, pelas intermináveis discussões teóricas sobre a ciência e a vida. À Mariana Veras, também 
dirijo um agradecimento especial pela parceria nas publicações, oportunidades e por instigar o exercício contínuo de conectar toxicologia e epidemiologia. Agradeço também ao Yuming Guo e ao Gary Adamkiewicz pelas contribuições para uma visão internacionalizada de diversos aspectos deste trabalho. Por fim, agradeço à Anna Maria Buheler e ao Victor Pereira Leite, colegas fundamentais em todas as etapas da revisão sistemática e metanálise. Em especial, agradeço ao Luiz Alberto Amador Pereira, colega de revisão, de sala e de discussões metodológicas.

Agradeço ainda às Fátimas e a Rosana por todo auxílio administrativo durante este processo, e às bibliotecárias Mabel Fernandes Figueiredo e Rosa Fischi. Agradeço à equipe do Instituto de Estudos Avançados da Universidade de São Paulo pelo ambiente acolhedor durante a finalização desta tese e à Fernanda pelo auxílio com algumas imagens.

Agradeço a FAPESP pelo apoio financeiro no primeiro ano desta pós-graduação e a ao Programa de Fisiopatologia Experimental e à Capes, pela Bolsa de apoio social recebida no restante da pós-graduação. Agradeço também ao Departamento de Patologia pela oportunidade de realizar o Curso de Especialização em Revisão Sistemática e Metanálise da Faculdade de Medicina da Universidade de São Paulo.

Por fim, mas acima de tudo, agradeço aos meus pais pela vida, pelo apoio, amor e estrutura recebidos durante este processo e pelos valores com os quais me criaram, fundamentais para a minha formação. Pelo mesmo motivo, obrigada Jairo, Bruno, Daniela e Marilena. À Marilena, agradeço também o apoio para formatar algumas figuras deste trabalho. 
"As melhores respostas guardam perguntas"

(Frase proferida durante aula da pós-graduação, ministrada pela Profa Teresinha Rios). 



\section{NORMATIZAÇÃO ADOTADA}

Esta tese está de acordo com as seguintes normas, em vigor no momento desta publicação:

Referências: adaptado de International Committe of Medical Journals Editors (Vancouver).

Universidade de São Paulo. Faculdade de Medicina. Divisão de Biblioteca e Documentação. Guia de apresentação de dissertações, teses e monografias. Elaborado por Anneliese Carneiro da Cunha, Maria Julia de A. L. Freddi, Maria F. Crestana, Marinalva de Souza Aragão, Suely Campos Cardoso, Valéria Vilhena. $3^{\text {a }}$ Ed. São Paulo: Divisão de Biblioteca e Documentação; 2011.

Abreviaturas dos títulos dos periódicos de acordo com List of Journals Indexed in Index Medicus. 



\section{SUMARIO}

Lista de abreviaturas e siglas

Resumo

Abstract

1. INTRODUÇÃO

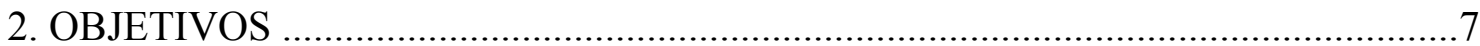

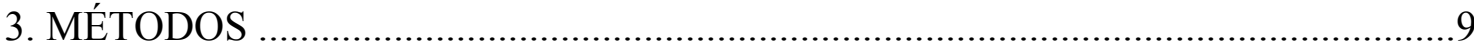

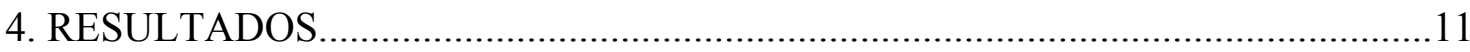

4.1. Estudos a partir da análise de dados secundários.................................................13

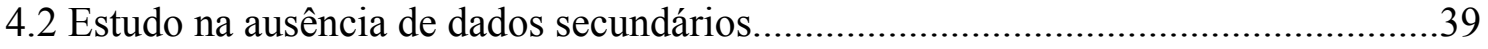

4.3. Estudos a partir da revisão sistemática e metanálise...............................................45

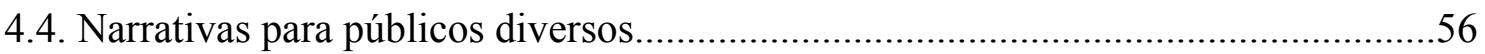

5. DISCUSSÃO

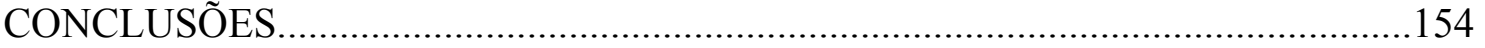

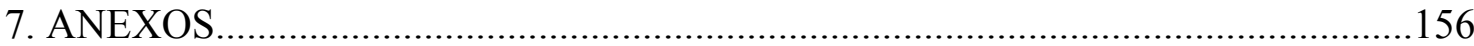

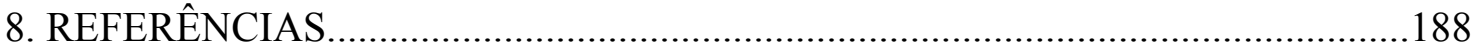





\section{LISTA DE ABREVIATURAS E SIGLAS}

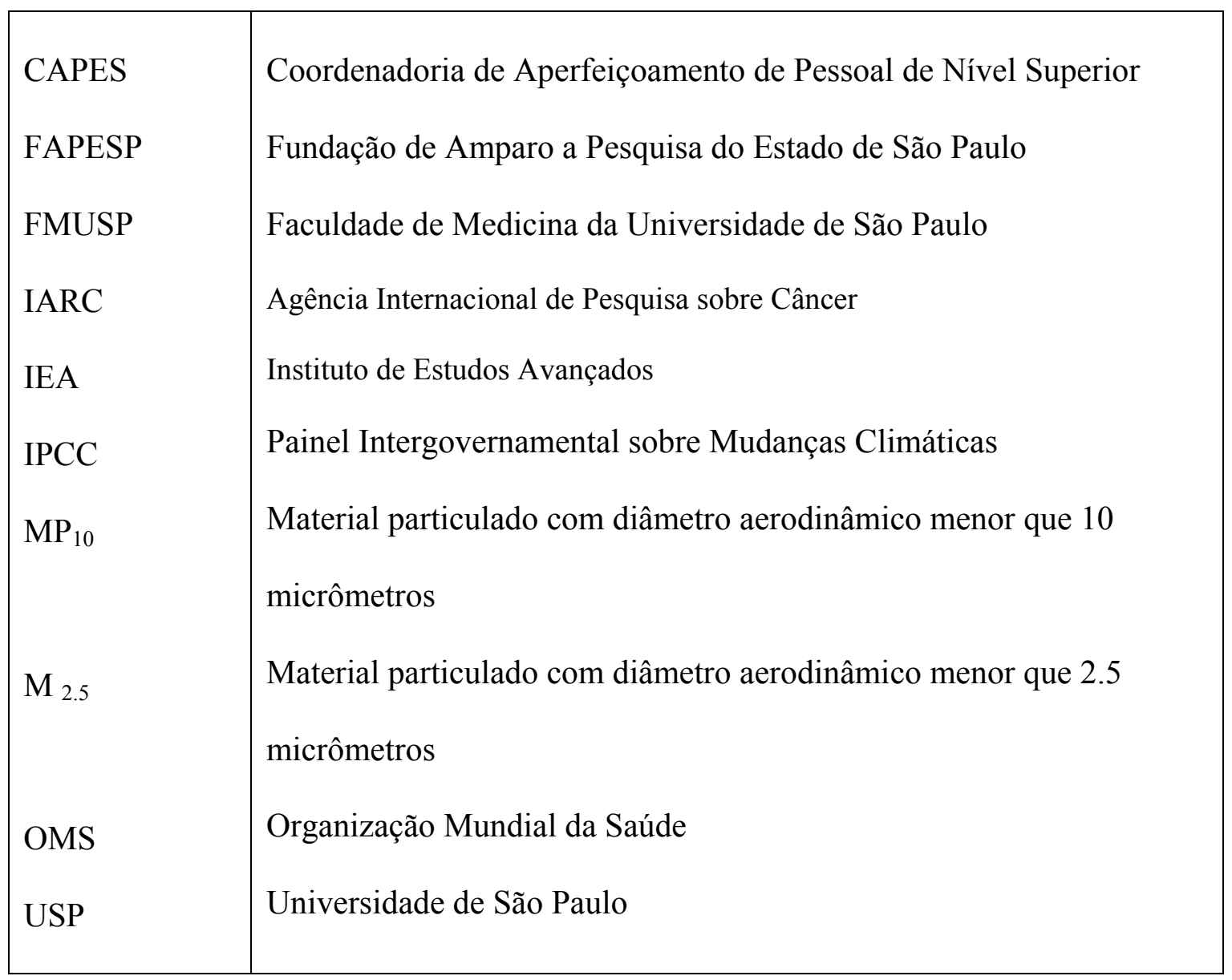





\section{RESUMO}

Fajersztajn L. Relações entre meio ambiente urbano e qualidade de vida: um estudo a partir do caso da poluição do ar. [tese]. São Paulo: Faculdade de Medicina, Universidade de São Paulo; 2016.

As cidades são hoje o habitat natural da espécie humana. Grande parte dos fatores de risco que mais contribuem para o adoecimento são altamente prevalentes nas cidades e são modificados pelo meio ambiente e estilo de vida urbanos, como poluição do ar, falta de saneamento básico, baixos níveis de atividade física, entre outros. Modificações no uso e ocupação do solo, ciclos geoquímicos, clima, sistemas hídricos e biodiversidade, em curso nas cidades, já as caracterizam como um ecossistema particular. Ecossistemas urbanos são complexos. Cada intervenção urbana acarreta uma série de efeitos na cidade, nem sempre previsíveis ou desejáveis, de modo que a governança urbana é um dos principais desafios de desenvolvimento do século XXI. Neste estudo procuramos entender algumas relações entre cidade e qualidade de vida, partindo do caso da poluição do ar. Postulamos que seria possível produzir artigos científicos de bom nível que permitissem integrar diferentes áreas de conhecimento numa linguagem adequada a um publico mais amplo, a fim de orientar formadores de opinião, gestores públicos e órgãos legislativos desejosos de estimular políticas voltadas para a promoção da qualidade de vida. Nesta tese apresentamos na íntegra oito artigos científicos produzidos sobre cidades e qualidade de vida que conduzimos ao longo deste estudo, divididos em quatro tipologias: 1) Estudos a partir da análise de dados secundários; 2) Estudo na ausência de dados secundários sistematizados, 3) Estudo a partir de revisão sistemática e metanálise e 4) Narrativas para públicos diversos. Sete estudos já foram, de alguma forma, publicados. Para fins desta tese, concluímos que é possível produzir artigos científicos de bom nível que integrem conhecimentos científicos de diferentes áreas do conhecimento numa linguagem compreensível para gestores e demais interessados em políticas voltadas para a promoção da qualidade de vida urbana.

Descritores: cidades; cidades saudáveis; metrópoles; saúde da população urbana; qualidade de vida; poluição do ar; monitoramento ambiental; neoplasias pulmonares; saúde pública. 



\section{ABSTRACT}

Fajersztajn L. Links between urban environment and quality of life: the case of air pollution. [Thesis]. São Paulo: "Faculdade de Medicina, Universidade de São Paulo"; 2016.

Cities are today the natural habitat of human beings. Most of the leading risk factors for the global burden of disease are highly prevalent in cities and are partially shaped by urban life style and the built environment (e.g. ambient air pollution, unsafe sanitation, low physical activity levels, among others). Changes in land use and cover, geochemical cycles, climate, hydrosystems and biodiversity are current in course in cities, thus cities can be considered a particular ecosystem. Urban ecosystems are complex, each urban intervention results in a wide range of effects, not all predicable or desired at fist. Urban governance is a major development challenge of the XXI century. In this study, we looked for selected links between cities and quality of life, focusing at first on air pollution-related issues. In this thesis we investigated if it was feasible to produce high quality scientific papers that integrate different scientific topics through a narrative suitable for a broader public: decision-makers and other actors interested in evidencebased urban polices for better quality of life. In this thesis, we depict the full text of eight scientific papers on urban health related issues produced during this postgraduation, seven of which already published. Papers are presented according to the following typologies: 1) Studies that used secondary data analysis, 2) Dealing with scarcity of secondary data, 3) Systematic Reviews and Meta-analysis and 4) Narratives for a wider public. We concluded that producing high quality scientific papers that integrate different scientific topics throughout a comprehensive language for a broader public interested in evidence-based urban polices for better quality of life in urban settlements is feasible.

Descriptors: cities; health city; metropolis; urban health; quality of life; air pollution; environmental monitoring; lung neoplasms; public health. 



\section{INTRODUÇÃO}

O domínio das técnicas de produção de alimentos foi determinante para que a maior parte dos seres humanos deixasse a vida nômade. A passagem do extrativismo para a agricultura mais sistematizada e a mudança da caça para a domesticação de animais, foram os elementos centrais para a nucleação de grupos de seres humanos, primeiramente em vilas com dúzias ou talvez centenas de pessoas que se conheciam e, posteriormente, em cidades com milhares de pessoas. A partir do progressivo exercício criativo do espírito humano, que produziu ofícios, corporações, guildas, comércio, arte e conhecimento, as cidades, por sua vez, foram os núcleos formativos das metrópoles, caracterizando a criação de um ecossistema muito particular. Com milhares/milhões de habitantes, as metrópoles impõem um desafio de convívio que, durante a maior parte da existência humana como espécie, era resolvido através da separação e formação de grupamentos humanos distintos ${ }^{(1)}$. No ecossistema das metrópoles, o adensamento populacional e a ausência de saneamento se acentuaram, criando condições propícias para o adoecimento, o qual, de certa forma, nublou o encantamento da urbanidade. A malária, a febre amarela, o tifo, e, atualmente, as novas doenças infecciosas, tem parte de suas biografias impressas no alfabeto esculpido pelos tijolos urbanos. Mais recentemente, temas como a violência do tráfego ou da criminalidade organizada e a formação de periferias desprovidas de infraestrutura onde as condições sanitárias retrocedem o viver para séculos anteriores, nublam ainda mais o encantamento da urbanidade. Ademais, a exclusão social, a imobilidade das artérias congestionadas das metrópoles, as ilhas de calor, a poluição "à moda dos fuzileiros navais (pelo ar, pelas águas, pelo solo)" e o rejuvenescimento de doenças infecciosas (também conhecidas por reemergentes), acrescentaram um pouco mais de Pathos (no sentido da caixa de 
Pandora) às cidades e subtraem delas um pouco mais do Logos. Em resumo, a saúde escapa da caixa da saúde, como se um Prometeu moderno fosse punido em um penhasco de concreto de um arranha-céu urbano, de forma a indicar que a gestão deste novo ecossistema depende de interações complexas.

As cidades são hoje o habitat natural da espécie humana e vieram para ficar. Mais da metade da população mundial vive em cidades e as projeções são de aumento contínuo $^{(2,3)}$. O ecossistema urbano já é a realidade do habitat de $80 \%$ da população latino-americana ${ }^{(3)}$ e $84 \%$ da população brasileira $^{(4)}$. O crescimento das cidades altera a paisagem, os ciclos geoquímicos, o clima, os sistemas hídricos e a biodiversidade ${ }^{(5-7)}$. Alimentar e fornecer energia e bens de consumo para tantos habitantes urbanos já é a principal causa das mudanças climáticas globais ${ }^{(2,8,9)}$. Vejamos alguns exemplos específicos das conexões do meio ambiente urbano e qualidade de vida dos seus habitantes. Morar próximo a um parque pode reduzir o risco de infarto do miocárdio, ao passo que a exposição à poluição do ar ambiente aumenta o risco ${ }^{(2,10-13)}$. Trocar a cobertura verde da cidade por asfalto e construir arranha-céus, interfere no microclima urbano, o que por sua vez, aumenta eventos extremos de temperatura e altera o regime de chuvas $^{(14,15)}$. Se outrora São Paulo foi a terra da garoa, hoje enfrenta períodos alternados de enchente e seca. Os extensos congestionamentos de veículos aumentam a concentração de poluentes atmosféricos, o que também interfere no microclima da cidade $^{(14)}$, além de prejudicar diretamente a saúde humana com efeitos negativos que vão desde ardor nos olhos e crises de asma até câncer de pulmão e morte ${ }^{(13,16-25)}$. A imobilidade do tráfego em São Paulo subtrai o tempo que os habitantes urbanos dispõem para outras atividades como sono, lazer, educação e autocuidado, a um custo anual estimado em mais de 40 bilhões de reais ${ }^{(24)}$. A opção pelo carro como meio de transporte, em detrimento ao transporte ativo (caminhar ou andar de bicicleta como 
parte ou na completude da jornada ao destino final), de um lado contribui para a poluição do ar local e para uma maior emissão de gases de efeito estufa, e de outro contribuem para o aumento do sobrepeso e obesidade na população ${ }^{(25,26)}$. Soma-se a isso, o crescente número de evidências científicas associando a exposição crônica ao ruído do tráfego a alterações cardíacas, distúrbios do sono, entre outros prejuízos à saúde $^{(27-29)}$. Em 2014, mais de mil pessoas morreram no trânsito de São Paulo ${ }^{(30)}$. No entanto, recomendar que as pessoas fiquem em casa com as janelas fechadas é inviável $^{(10)}$. A adoção de hábitos saudáveis pode ser favorecida ou dificultada pelo ambiente construído e pelo modo como a cidade está organizada ${ }^{(31-33)}$. Além disso, alguns fatores de risco para doenças, independem ou dependem muito pouco de escolhas individuais, mas sim de ações governamentais ${ }^{(10,11)}$.

No ecossistema urbano quem determina se um local vai abrigar um parque ou um prédio, ou se um rio vai dar lugar a uma avenida, não são as regras clássicas da natureza, são regras ditadas pelo sistema de gestão das cidades ${ }^{(34)}$, que sofrem influência de valores culturais e econômicos que mudam muito rapidamente. Sendo assim, as Nações Unidas ${ }^{(3)}$ tem destacado a governança urbana como o desafio de desenvolvimento central no século XXI.

Recentemente, a Science dedicou uma edição inteira mostrando que cidades são sistemas complexos, que o mundo já está urbanizado e que a governança das cidades afetará de forma determinante as gerações futuras ${ }^{(2)}$. No campo específico da Saúde, a comunidade científica tem mostrado que políticas de baixo carbono, advogadas internacionalmente como fundamentais para enfrentar as mudanças climáticas, também reduzem a poluição do ar local e trazem benefícios para a saúde populacional ${ }^{(35-44)}$. Tais políticas, tem sido advogadas como a principal oportunidade para promover a saúde global no século XXI ${ }^{(39,40)}$. Desde 1987 a Rede Europeia de Cidades Saudáveis, 
hospedada na Organização Mundial de Saúde (OMS), de certa forma reconhece esta oportunidade e reúne cidades comprometidas com a saúde e com o desenvolvimento sustentável. A cada cinco anos, a rede seleciona temas específicos para discussão e ação. Na primeira fase a iniciativa contava com 35 cidades com o objetivo comum de introduzir novas formas de pensar e promover cidades saudáveis. Hoje com cerca de 100 cidades, a rede está na fase VI, cujas metas são: 1) melhorar a saúde de todos os cidadãos e reduzir as inequidades de saúde e 2) aprimorar a liderança e a participação na governança de saúde ${ }^{(45)}$.

Iniciativas semelhantes são raras na América Latina e no Brasil. Tomemos como exemplo a poluição do ar. A despeito do aumento exponencial das evidências sobre os impactos negativos dos poluentes atmosféricos na saúde humana ${ }^{(13,17,18,21-23)}$, a poluição do ar persiste em muitas regiões do mundo e aumenta em algumas regiões do Brasil e América do $\mathrm{Sul}^{(46)}$. Nos últimos anos o Brasil presenciou avanços importantes na melhoria da qualidade do ar, como a eliminação do uso do fogo durante o processo de colheita de cana de açúcar em áreas mecanizáveis no Estado de São Paulo . No entanto, também testemunhou retrocessos, como a suspensão, em 2014, da inspeção veicular ambiental iniciada em 2009 no município de São Paulo e o projeto de lei em tramitação que libera a fabricação e comercialização de carros a diesel ${ }^{\dagger}$.

Formada em Fisioterapia, fui treinada a olhar de frente problemas (deficiências, incapacidades e dores dos pacientes) muitas vezes negligenciados pela sociedade. Fui também treinada a identificar as potencialidades remanescentes dos pacientes, como

\footnotetext{
* O Protocolo Agroambiental do Setor Sucroenergético, é um acordo voluntário assinado em 2007 pelo Governador de São Paulo, pelos Secretários de Estado do Meio Ambiente e de Agricultura e Abastecimento e pelo presidente da União da Indústria Sucroalcooleira que antecipou o fim da desespalha da cana por meio do uso de fogo para 2014 (nas áreas mecanizáveis, para todas as unidades industriais signatárias) e 2017 (áreas não mecanizáveis), além da recuperação de matas em nascentes e a proteção das áreas de preservação de outros cursos d'água.

${ }^{\dagger}$ Projeto de Lei no 1.013/2011.
} 
suas condições musculares, e trabalha-las para obtenção de um melhor desempenho funcional. Com o tempo fui percebendo que o modo de vida urbano e a cidade construída influenciavam a qualidade dos resultados de tratamento para níveis muito além daqueles que aprendi na graduação. Um exemplo clássico é a frequência semanal do tratamento, sempre desafiada pela difícil mobilidade na cidade de São Paulo, ou ainda, o agravamento dos sintomas respiratórios durante os dias mais poluídos. Esses desafios me levaram a procurar respostas sobre as relações entre saúde e cidade no terceiro setor, onde, à semelhança do meu treinamento em Fisioterapia, comecei a olhar para para alguns problemas da cidade, de certa forma também neglicenciados, e a tentar identificar potencialidades que pudessem auxiliar na resolução dos mesmos. No terceiro setor desenvolvi trabalhos em conjunto com o Laboratório de Poluição Atmosférica Ambiental da Faculdade de Medicina da Universidade de São Paulo. Reconhecido internacionalmente pelos seus estudos toxicológicos, clínicos e epidemiológicos em escala local e regional, o laboratório tem contribuição determinante para a liderança global da Universidade de São Paulo entre as 15 que mais publicam sobre poluição do ar e saúde no mundo ${ }^{*}$. Frente a tanto conhecimento produzido, percebi que, embora o papel da ciência nas sociedades democráticas da atualidade seja guiar os debates e informar a tomada de decisão sobre assuntos relevantes de interesse público ${ }^{(47)}$, a transformação do conhecimento científico em melhores decisões políticas não ocorre de forma natural ${ }^{(48)}$. Em concordância com Lorente e Álvarez-Herranz ${ }^{(49)}$ e outros autores $^{(50-52)}$, me convenci que a poluição ambiental não vai desaparecer sozinha, conforme o crescimento econômico e, que a qualidade ambiental, depende de políticas públicas. O mesmo vale para outras exposições urbanas que influenciam a saúde humana.

\footnotetext{
* Pesquisa realizada em 03 de maio de 2016 na plataforma on-line Scopus. Termos de busca: "air pollution" e "health", filtro "Affiliation".
} 
Dado a complexidade da relação entre urbanidade e qualidade de vida, entrei na pós-graduação a fim de adquirir habilidades que me permitissem integrar os diferentes saberes inerentes ao entendimento dos sistemas urbanos, seguindo os objetivos expostos a seguir. 


\section{OBJETIVOS}

A hipótese do presente estudo foi que seria possível produzir artigos científicos de bom nível* que, ao mesmo tempo, permitissem integrar diferentes áreas de conhecimento e orientar formadores de opinião, gestores públicos e órgãos legislativos desejosos de estimular políticas voltadas para a promoção da saúde e qualidade de vida. Como o tema em si é por demais amplo, utilizei como plataforma central o tema da poluição atmosférica, problema notório de saúde pública e, cuja resolução demanda o entendimento de várias áreas do conhecimento e, portanto, um típico exemplo de integração de saberes e políticas de cunho multi e transdisciplinar.

Os objetivos específicos deste doutoramento foram sendo construídos no decorrer do estudo, na medida do progressivo desenvolvimento das minhas habilidades, como também as de meu orientador. Neste período, o objeto de estudo em si - a poluição do ar - também se alterou. Por exemplo, muitos dos desfechos adversos de saúde associados à poluição, como o câncer do pulmão, passaram do nível de incerteza para o de certeza e se deslocaram para o ambiente urbano. Os objetivos específicos do presente estudo serão definidos no corpo de cada uma das publicações, as quais são, de fato, o corpo desta tese, e estão descritas na seção de Resultados.

\footnotetext{
${ }^{*}$ Definidos para fins deste estudo como aqueles publicados em periódicos que utilizam análise por pares.
} 


\section{MÉTODOS}

Para testar a hipótese deste estudo, eu e meu orientador, entendemos que era necessário não só produzir ciência, como também suas correspondentes narrativas. Para fins deste estudo, definimos narrativa como uma interpretação de achados científicos construída de forma que um público geral tenha a possibilidade de compreendê-las.

Testamos a hipótese deste estudo a partir de um conjunto de publicações, por vezes diferentes em suas metodologias científicas formais, mas conectadas pelo mesmo tema - urbanidade e qualidade de vida - e também pelo foco na construção de suas respectivas narrativas voltadas para um público mais abrangente, como definido no primeiro parágrafo desta seção. Deste modo, os estudos foram sendo desenvolvidos a partir dos desdobramentos de uma primeira pergunta: "países com maior produção científica sobre poluição do ar e saúde respiram ar de melhor qualidade?”. Em concordância com os objetivos, os métodos foram sendo construídos no decorrer do estudo, na medida do progressivo desenvolvimento das minhas habilidades, como também de meu orientador. Por exemplo, quando passei minha pós-graduação do mestrado para o doutorado direto, acordei com meu orientador que eu aprenderia técnicas de revisão sistemática e metanálise, fundamentais para aprimorar a sumarização e interpretação de evidências científicas. Deste modo, descreveremos a seguir as principais interações e capacitações que viabilizaram as publicações resultantes deste estudo.

Como capacitação, eu realizei disciplinas não só na Faculdade de Medicina da Universidade de São Paulo (FMUSP), mas também em diferentes unidades da Universidade de São Paulo (USP) como, Faculdade de Saúde Pública, Faculdade de Filosofia Letras e Ciências Humanas e Faculdade de Direito. A fim de aprofundar meus 
conhecimentos em epidemiologia, fui monitora de disciplinas introdutórias da área nos níveis de graduação e de pós-graduação e hoje integro a direção da rede de Estudantes e Novos Pesquisadores da Sociedade Internacional de Epidemiologia Ambiental*. Destaco que conclui uma especialização de um ano em Revisão Sistemática e Metanálise, oferecida pelo Departamento de Patologia da FMUSP e um curso de curto período de introdução ao geoprocessamento com o programa Terra View Política Social.

Como meios de interação em nível institucional, destaco a articulação com a estrutura do Instituto de Estudos Avançados (IEA) da Universidade de São Paulo e minha experiência prévia no terceiro setor. Em nível pessoal, interagi com toxicologistas, geógrafos, epidemiologistas, médicos, climatologistas, estatísticos e biólogos, especializados em poluição do ar, desigualdades sociais, entre outros. Destaco ainda interações internacionais com pesquisadores das universidades de Harvard e Queensland. Muitos desses contatos foram cruciais para a minha formação e resultaram em parcerias de estudo, como evidenciado pela coautoria dos manuscritos apresentados na seção de Resultados.

A descrição específica dos métodos utilizados em cada um dos estudos que compõe esta tese está no corpo dos mesmos (vide seção de Resultados). Quando ausentes, pode-se considerar revisão critica de literatura como metodologia.

Por fim destaco que este estudo foi aprovado pelo Comitê de Ética em Pesquisa da Faculdade de Medicina da Universidade de São Paulo, em sessão de 06/06/2012, Protocolo de Pesquisa nº 162/12 (vide seção de Anexos, Anexo A).

\footnotetext{
* Dirigida por 13 jovens pesquisadores do mundo inteiro, rede é conhecida pelo seu nome em inglês: The Students and New Researchers Network (SNRN). Para mais informações vide o site da Sociedade Interncaional de Epidemiologia Ambiental: http://www.iseepi.org/About/snrn.htm
} 


\section{RESULTADOS}

Durante a pós-graduação, eu produzi conhecimento científico e suas correspondentes narrativas a partir de pesquisa original, da avaliação e sumarização do conhecimento científico já produzido e também utilizando e analisando dados secundários para a construção das narrativas. Para fins desta tese, eu e meu orientador dividimos os estudos em quatro tipologias:

4.1. Estudos a partir da análise de dados secundários

4.2. Estudo na ausência de dados secundários sistematizados

4.3. Estudo a partir de revisão sistemática e metanálise

4.4. Narrativas para públicos diversos

A seguir, descrevemos as quatro tipologias e apresentamos os manuscritos correspondentes na forma em que foram publicados, ou na forma em que foram preparados para publicação. Uso a primeira pessoa para descrever os manuscritos. No entanto meu orientador foi fundamental para elaboração de todos os estudos e correspondentes narrativas. Também contei com a colaboração fundamental de outros pesquisadores durante a condução do estudo, como mostrado na autoria dos manuscritos, e fui coautora de um dos manuscritos. 
4.1. Estudos a partir da análise de dados secundários

Nesta tipologia analisei dados secundários públicos para construir narrativas sobre dois assuntos relacionados à urbanização e saúde: a) poluição do ar e câncer e b) co-benefícios para a saúde advindos de politicas de baixo carbono no setor de transportes.

\subsubsection{Poluição do ar e câncer}

No artigo sobre poluição do ar e câncer ${ }^{(53)}$ realizei uma revisão dos principais estudos longitudinais relacionando exposição à poluição do ar e câncer. $\mathrm{O}$ câncer foi escolhido como a doença de interesse porque no momento em que estava conduzindo o estudo, o IARC* discutia se a poluição do ar era carcinogênica para humanos, o que de fato se confirmou poucos meses depois ${ }^{(54,55)}$. A revisão demonstrou que os principais estudos foram realizados na Europa e América do Norte. A Ásia também contribuía com alguns estudos relevantes, mas os demais continentes, onde se concentram a maioria dos países em desenvolvimento, não tinham estudos com essas características. A revisão ainda mostrou que, no geral, o risco era significativamente aumentado, porém pequeno, comparado a outros agentes potencialmente modificáveis, como a fumaça do tabaco. A fim de construir uma narrativa mostrando que apesar de relativamente baixo, a poluição do ar era um fator de risco importante para o câncer, usei dados secundários para mostrar a exposição global à poluição do ar por densidade populacional e apresentei a informação visualmente, num mapa global. Para a construção da narrativa, também mostrei visualmente que os países com maior produção científica sobre poluição do ar e saúde, no geral, apresentavam melhor qualidade do ar. Comparei a produção de ciência sobre poluição do ar e saúde com a produção de ciência sobre

\footnotetext{
* IARC corresponde à sigla em inglês que designa a Agência Internacional de Pesquisa sobre Câncer, vinculada à Organização Mundial da Saúde.
} 
outros fatores de risco ambientais importantes para saúde, cujas projeções para as próximas décadas são de declínio: malária e qualidade da água. O mapeamento dessa informação foi fundamental na construção da narrativa. $\mathrm{O}$ artigo foi publicado numa revista de alto impacto $\left(\mathrm{JCR}^{*} 37,912\right.$ em 2013$)$, mostrando que a uma narrativa bem construída usando revisão da literatura e dados secundários no momento certo é uma estratégia eficiente de publicação. Até julho de 2016 o artigo contava com 32 citações na plataforma Web of Science (mantida pela Thompson Reuters). A publicação na Nature Reviews Cancer demonstra que consegui construir uma narrativa sobre poluição e câncer para um público mais geral, notadamente oncologistas. O estudo recebeu o prêmio "2013 DOW Sustainability Innovation Student Challenge Award”, concedido pela Universidade de São Paulo, em parceria com a companhia química Dow. A publicação deste artigo foi o meu principal argumento para pleitear a mudança do projeto de mestrado para doutorado direto, o que foi concedido pelo Programa de PósGraduação em Fisiopatologia Experimental, considerando a recomendação da Banca Julgadora do Exame de Qualificação do Mestrado em 2013 e de meu orientador. A seguir apresento o artigo na íntegra.

\footnotetext{
* JCR é a sigla em inglês para Journal Citation Report, uma avaliação anual do impacto e desempenho das revistas internacionais realizada pela Thompson Reuters.
} 
Artigo publicado

PERSPECTIVES

SCIENCE AND SOCIETY

\section{Air pollution: a potentially modifiable risk factor for lung cancer}

\author{
Lais Fajersztajn, Mariana Veras, Ligia Vizeu Barrozo and Paulo Saldiva
}

Abstract| Economic growth and increased urbanization pose a new risk for cancer development: the exposure of high numbers of people to ambient air pollution. Epidemiological evidence that links air pollution to mortality from lung cancer is robust. An ability to produce high-quality scientific research that addresses these risks and the ability of local health authorities to understand and respond to these risks are basic requirements to solve the conflict between economic development and the preservation of human health. However, this is currently far from being achieved. Thus, this Science and Society article addresses the possibilities of expanding scientific networking to increase awareness of the risk of lung cancer that is promoted by air pollution.

Determining the contribution of potentially modifiable risk factors (also known as cause-specific analysis for cancer) is crucial to implement cancer-preventive health policies ${ }^{1}$. Air pollution - household air pollution from burning solid fuels (for heating and cooking) and ambient particulate matter - was listed as one of the ten leading risk factors for the global burden of disease in 2010 (REF. 1). Most of these diseases are due to respiratory and cardiovascular events $\mathrm{s}^{2-5}$, but cancer is also an important outcome $e^{1,35-11}$. Lung cancer has the most robust association with prolonged exposure to air pollution, particularly when pollution is expressed in terms of particulate matter or gaseous components of air pollution. In fact, as exposure to higher concentrations of particulate matter increases, lung cancer becomes proportionally more important than cardiovascular events to the burden of disease ${ }^{11}$. For lung cancer mortality, excess risks rose nearly linearly throughout the full range of exposure to particulate mat ter, with a median aerodynamic diameter of less than $2.5 \mu \mathrm{m}\left(\mathrm{PM}_{2}\right.$; fine particulate matter), whereas the slope of the curve for cardiovascular mortality was less steep. Currently, $8 \%$ of global lung cancer deaths can be attributed to exposure to fine particulate matter alone ${ }^{3}$, although this estimate can be much higher (12.8\%; confidence interval (CI) $95 \%=5.9-18.5$ ) if fine particles that are generated from human activity (as determined from satellite-derived assessments) are taken into account ${ }^{12}$. The doseresponse relationship relating lung cancer and ambient particulate matter might be higher then previously estimated, particularly if only adenocarcinomas of the lung are considered. A recent European report that combined 17 long-term cohort studies in nine European countries identified a risk of 1.55 per $5 \mu \mathrm{g}$ per $\mathrm{m}^{3}$ of $\mathrm{PM}_{2.5}$ (hazard ratio $1.55 ; 95 \% \mathrm{CI}=1.05-2.29)^{51}$. There is also a growing body of evidence that associates air pollution exposure to an increased risk of cancer in other tissues, such as the breast $^{13-16}$, haematopoietic tissues ${ }^{17,18}$ and the urinary tract ${ }^{7,19-22}$.

Air pollution and global burden of disease Exposure to outdoor air pollution is expected to become the top environmental cause of premature mortality globally by 2050 , overtaking malaria and water quality, which are traditional environmental risks for premature deaths, and the numbers of deaths from both of these are expected to fall over the same period ${ }^{23}$. The effect will be greater in developing countries that are not members of the Organization for Economic Cooperation and Development (OECD): these countries include Brazil, Russia, India, Indonesia, China and South Africa (BRIICS), as well as developing countries in the rest of the world ${ }^{23}$. There are densely populated regions in the world that have high air pollution concentrations (FIG. 1), especially megacities of developing nations. Fast urban and industrial development in these countries has resulted in growing demands for energy and rising expectations of material goods ${ }^{24}$. Therefore, megacities combine both concentrated emissions of air pollutants and large numbers of exposed people ${ }^{25}$.
On a minor scale, hot spots of vulnerability can even occur in developed urban settings ${ }^{26}$. It is important to note that most of the epidemiological evidence relating air pollution to lung cancer has reported a linear dose-response effect ${ }^{3,9,10,27-35,51}$ (TABLE 1). However, these studies were carried out in the United States ${ }^{3,9,10,31,32}$ or Europe $e^{27-30,51}$, which are areas with substantially lower levels of air pollution than those of developing countries. Studies in areas with higher pollution levels and high population levels are scarce ${ }^{33-35}$ (TABLE 1) and are badly needed. Thus, this Science and Society article addresses the possibility of expanding scientific networking to increase awareness of the risk of lung cancer that is promoted by air pollution, especially in areas of the world where pollution is likely to be a substantial risk factor for lung cancer development and death.

\section{Air pollution and cancer risk}

Although the relative risk of developing cancer as a result of exposure to air pollu tion is generally small, the attributable risk (relative risk multiplied by the number of exposed people) is high, transforming ambient air pollution into the most significant environmental risk factor for lung cancer ${ }^{1}$. Indeed, lung cancer burden from air pollution is probably underestimated. Most of the long-term exposure studies for this pollutant have been carried out in areas where annual average concentrations range between $5 \mu \mathrm{g}$ and $35 \mu \mathrm{g}$ per $\mathrm{m}^{3}$; however, the average con centrations of particulate matter in the major population centres of China, India and other developing countries are often much higher, and can exceed $100 \mu \mathrm{g}$ per $\mathrm{m}^{3}$ according to recent estimates ${ }^{25}$.

Specific pollutants or complex mixtures? Particulate matter can be considered as a mixture of air pollution sources that are present in the urban atmosphere rather than as a single pollutant. Particulate matter represents a complex mixture of solid and liquid components, which can vary substantially in composition and size depending on the emission source and prevailing weather conditions ${ }^{36}$. The composition and size of these particles determine the potential for deposition in the respiratory tract and the health effects that are associated with exposure ${ }^{37}$. Particles are classified according to their size, which can range from $0.005 \mu \mathrm{m}$ to $100 \mu \mathrm{m}$ in diameter. The smaller the size of the particle the greater its potential to penetrate deep into the respiratory tract ${ }^{36}$. 
PERSPECTIVES

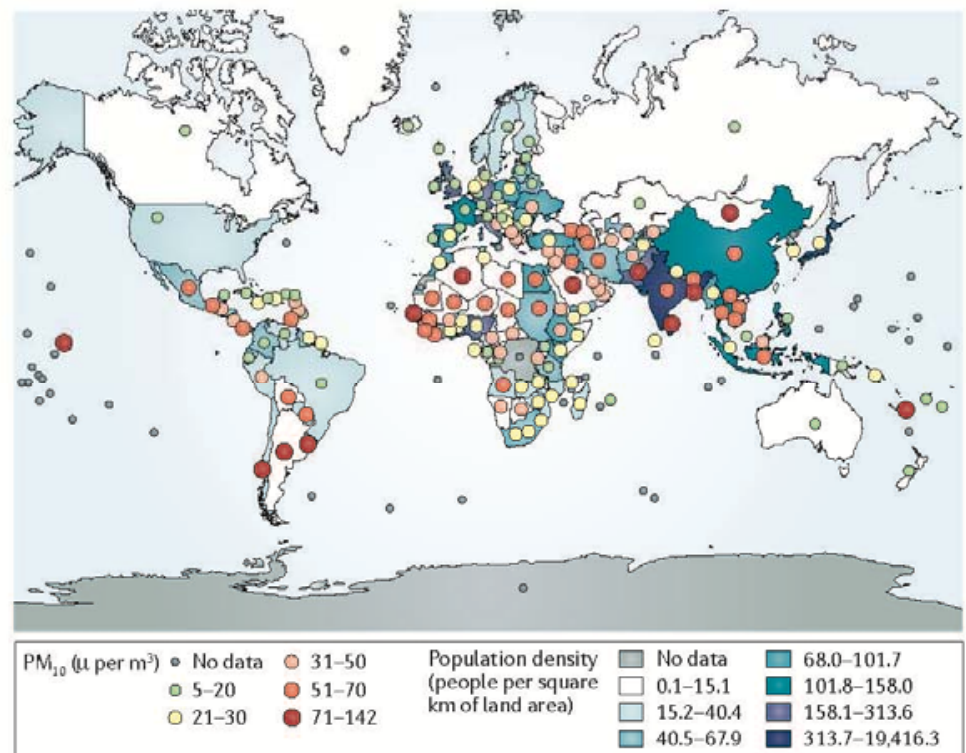

Figure 1 Global annual mean $\mathrm{PM}_{10}$ concentrations in 2009 by population density. The map com pares the population density in 2009 (data from the World Bank ${ }^{\text {i9 }}$ ) with the annual mean concentration of particulate matter of $100 \mu$ m or less $\left(\mathrm{PM}_{10}\right)$ in 2009 (data from the World Bank ${ }^{30}$ ).

The composition of these particles includes different classes of organic and inorganic chemicals, such as heavy and transition metals, organic compounds, hydrocarbons, ions, condensed reactive gas products and microorganisms. At higher concentrations the particles can also include microorganismal products (such as endotoxins), nitrates, sulphates and elemental carbon. Some of these particulates, such as polycyclic aromatic hydrocarbons, are known carcinogen $s^{3738}$. Recently, diesel emissions, a substantial contributor to urban particles, were considered to be class I carcinogens by the International Agency of Research on Cancer ${ }^{38}$, meaning that there is scientific evidence of carcinogenicity in humans.

In European and some Asian studies, significant associations were obtained relating lung cancer risk to gaseous compo nents of air pollution, such as $\mathrm{NO}_{2}$ and $\mathrm{SO}_{2}$ (REFS 28-30,34,35). $\mathrm{NO}_{2}$ has been shown to be a good indicator of traffic-related pollution ${ }^{39}$, and $\mathrm{SO}_{2}$ can be used to estimate diesel and industrial emissions. It is important to note that large cohort studies on lung cancer and air pollution rely on measures of specific pollutants. However, the atmosphere contains many compounds with known carcinogenic potential, such as polycyclic aromatic hydrocarbons and heavy metals, levels of which are not plex mixture, it is difficult to ascribe the responsibility of causing lung cancer to a single component. Until a clear pathogenetic mechanism is defined, it would be prudent to consider the pollutants mentioned above as possible substitute markers of sources of air pollution, such as traffic or industrial pollution.

\section{Air pollution control}

The National Ambient Air Quality Standards (NAAQS), set up in the United States as part of the Clean Air Act, has been effective in controlling air quality ${ }^{40}$, and it is a policy that has been recommended by the World Health Organization since 1987 (REF. 41). The stringency of air pollution control procedures varies substantially world wide $\mathrm{e}^{42}$. Indeed, a comprehensive global analysis that reviewed the 24-hour NAAQS for $\mathrm{PM}_{10}$ (particulate matter with a median aerodynamic diameter of less than $10 \mu \mathrm{m}$ ) revealed a positive correlation between the stringency of the NAAQS and the average annual exposure to $\mathrm{PM}_{10}$, meaning that less stringent air quality standards lead to higher air pollution concentrations ${ }^{42}$. Efforts to control the sources of ambient air pollution should be considered a public health strategy to reduce lung cancer incidence, similar to the strategies that apply to tobacco and asbestos. routinely measured. Thus, in such a com-
The process of reducing the use of asbestos and tobacco raised considerable public health controversies, which were driven by political, economic and individual liberty arguments. In the case of air pollution, the adoption of effective policies to control emission levels will be conceivably more challenging, as these policies will call into question our present use of energy and our apparently unbreakable dependence on personal motorized vehicles. Energy production - including oil and thermoelectric power - and the automobile industry represent enormous economic interests, and 'modern life' is based on increased energy use, which has become incorporated into our culture. Thus, a reduction in particulate matter levels will demand a considerable behavioural change. Traffic is one of the major sources of particulate matter ${ }^{39}$. Substantial technological advances have improved the efficiency of the nineteenth century internal combustion engine, leading to a reduction of air pollution concentrations. However, although air pollution from motorized vehicles has decreased in cities in Europe and North America as a result of more efficient petrol and diesel engines, it has not decreased as much as was hoped ${ }^{25}$ This is because the increase in road traffic and the resulting decrease in vehicle velocity are offsetting the gains that have been made by better car technology. In São Paulo, Brazil, particulate matter concentrations were decreasing progressively from 1996 to 2004 , but they have remained unchanged since 2004 (REF. 43), indicating that technology alone will not be a solution if the numbers of vehicles and their intensity of use continue to increase. The same is true for the generation of electricity based on fossil fuels (coal, petroleum and gas); $40 \%$ of the electricity produced worldwide is currently generated from the combustion of coal, and this percentage is expected to rise in the next few decades as worldwide energy demands increase ${ }^{44}$. Thus, this will offset any improvements to levels of particular matter that have been gained through the use of modern thermoelectric power plants ${ }^{45,46}$. Moreover, the technological benefits of more advanced combustion engines and energy generation processes are not evenly distributed across the globe. One particularly difficult challenge is to tackle the lack of access to clean energy and the dependence of many people in low-income settings on inefficient and inadequately ventilated burning of biomass for household energy needs ${ }^{44,47,48}$. In this scenario, there are links between indoor and outdoor sources 


\section{PERSPECTIVES}

\begin{tabular}{|c|c|c|c|c|c|}
\hline Study & Setting & $N$ (follow-up period) & $\begin{array}{l}\text { Pollutant } \\
\text { considered }\end{array}$ & Estimated risk & Adjustments \\
\hline \multicolumn{6}{|l|}{ Europe } \\
\hline \multirow[t]{5}{*}{$\begin{array}{l}\text { Beelen } \\
\text { et } a l^{27}\end{array}$} & \multirow[t]{5}{*}{ Netherlands } & \multirow[t]{5}{*}{$111,378(1986-1997)$} & $\begin{array}{l}\text { Blacksmoke } \\
\text { concentration }\end{array}$ & $\begin{array}{l}\mathrm{RR}(95 \% \mathrm{Cl})=1.47(1.01-2.16) \text { for } \\
\text { never smokers; } 0.91(0.68-1.23) \\
\text { for ex-smokers; and } 0.85 \\
(0.70-1.03) \text { for current smokers }\end{array}$ & \multirow[t]{5}{*}{ Age, sex, smoking status and SES } \\
\hline & & & $\begin{array}{l}\text { Blacksmoke }(10 \mu \mathrm{g} \\
\left.\text { per } \mathrm{m}^{3}\right)\end{array}$ & $\operatorname{RR}(95 \% \mathrm{Cl})=1.03(0.78-1.34)$ & \\
\hline & & & $\mathrm{NO}_{2}\left(30 \mu \mathrm{g}\right.$ per $\left.\mathrm{m}^{3}\right)$ & $R R(95 \% C l)=0.86(0.57-1.29)$ & \\
\hline & & & $\mathrm{PM}_{2.5}\left(10 \mu \mathrm{g}\right.$ per $\left.\mathrm{m}^{3}\right)$ & $\operatorname{RR}(95 \% \mathrm{Cl})=0.65(0.41-1.04)$ & \\
\hline & & & $\mathrm{SO}_{2}\left(20 \mu \mathrm{g}\right.$ per $\left.\mathrm{m}^{3}\right)$ & $\operatorname{RR}(95 \% \mathrm{Cl})=1.01(0.67-1.54)$ & \\
\hline \multirow[t]{4}{*}{$\begin{array}{l}\text { Brunekreef } \\
\text { et al. } .^{28}\end{array}$} & \multirow[t]{4}{*}{ Netherlands } & \multirow[t]{4}{*}{$120,000(1987-1996)$} & $\begin{array}{l}\text { Blacksmoke }(10 \mu \mathrm{g} \\
\left.\text { per } \mathrm{m}^{3}\right)\end{array}$ & $\operatorname{RR}(95 \% \mathrm{Cl})=1.03(0.88-1.20)$ & \multirow[t]{4}{*}{ Age, sex, smoking status and SES } \\
\hline & & & $\left.\mathrm{NO}_{2}(30 \mu g \text { per m})^{3}\right)$ & $\operatorname{RR}(95 \% \mathrm{Cl})=0.91(0.72-1.15)$ & \\
\hline & & & $\mathrm{PM}_{2.5}\left(10 \mu \mathrm{g}\right.$ per $\left.\mathrm{m}^{3}\right)$ & $R R(95 \% C l)=1.06(0.82-1.38)$ & \\
\hline & & & $\mathrm{SO}_{2}\left(20 \mu \mathrm{g}\right.$ per $\left.\mathrm{m}^{3}\right)$ & $\operatorname{RR}(95 \% \mathrm{Cl})=1.00(0.79-1.26)$ & \\
\hline $\begin{array}{l}\text { Cesaroni } \\
\text { et al. }{ }^{29}\end{array}$ & Italy & $1,265,058(2001-2010)$ & $\mathrm{NO}_{2}\left(10 \mu \mathrm{g}\right.$ per $\left.\mathrm{m}^{3}\right)$ & $\mathrm{HR}(95 \% \mathrm{Cl})=1.04(1.02-1.07)$ & $\begin{array}{l}\text { Age, sex, maritalstatus, place of } \\
\text { birth, education, occupation and } \\
\text { area-based socioeconomic position }\end{array}$ \\
\hline \multirow{2}{*}{$\begin{array}{l}\text { Heinrich } \\
\text { et al. }{ }^{30}\end{array}$} & \multirow[t]{2}{*}{ Germany } & \multirow[t]{2}{*}{$4,800(1980-2008)$} & $\mathrm{NO}_{2}\left(16 \mu\right.$ ger $\left.\mathrm{m}^{3}\right)$ & $\operatorname{HR}(95 \% \mathrm{Cl})=1.25(0.72-2.17)$ & \multirow[t]{2}{*}{ Age, smoking status and education } \\
\hline & & & $\mathrm{PM}_{10}\left(7 \mu \mathrm{g}\right.$ per $\left.\mathrm{m}^{3}\right)$ & $\operatorname{HR}(95 \% \mathrm{Cl})=1.97(0.59-6.57)$ & \\
\hline \multirow[t]{2}{*}{$\begin{array}{l}\text { Raaschou- } \\
\text { Nielsen } \\
\text { et al. }{ }^{51}\end{array}$} & \multirow[t]{2}{*}{$\begin{array}{l}\text { Nine } \\
\text { European } \\
\text { countries }\end{array}$} & \multirow[t]{2}{*}{$\begin{array}{l}312.944 \text { (mean of } 12.8 \\
\text { years) }\end{array}$} & $\mathrm{PM}_{10}\left(10 \mu \mathrm{g}\right.$ per $\left.\mathrm{m}^{3}\right)$ & $\begin{array}{l}\mathrm{HR}(95 \% \mathrm{Cl})=1.22(1.03-1.45) \text { for } \\
\text { all lung cancers; } 1.51(1.10-2.08) \\
\text { for adenocarcinomas of the lung }\end{array}$ & \multirow[t]{2}{*}{ Age, sex, smoking status and SES } \\
\hline & & & $\mathrm{PM}_{2.5}\left(5 \mu \mathrm{g}\right.$ per $\left.\mathrm{m}^{3}\right)$ & $\begin{array}{l}\mathrm{HR}(95 \% \mathrm{Cl})=1.18(0.96-1.46) \text { for } \\
\text { all lung cancers; } 1.55(1.05-2.29) \\
\text { for adenocarcinomas of the lung }\end{array}$ & \\
\hline \multicolumn{6}{|c|}{ North America } \\
\hline $\begin{array}{l}\text { Dockery } \\
\text { et } a .^{31}\end{array}$ & $\begin{array}{l}\text { United } \\
\text { States }\end{array}$ & $8,111(1974-1991)$ & $\mathrm{PM}_{2.5}\left(18.6 \mu \mathrm{g}\right.$ per $\left.\mathrm{m}^{3}\right)$ & $\operatorname{AMR}(95 \% \mathrm{CI})=1.37(0.81-2.31)$ & $\begin{array}{l}\text { Age, sex, smoking status, education, } \\
\text { occupational exposure and medical } \\
\text { history }\end{array}$ \\
\hline $\begin{array}{l}\text { Jerrett } \\
\text { et } \text { al. }^{32}\end{array}$ & $\begin{array}{l}\text { United } \\
\text { States }\end{array}$ & $22,905(1982-2000)$ & $\mathrm{PM}_{2.5}\left(10 \mu g\right.$ per $\left.\mathrm{m}^{3}\right)$ & $\mathrm{HR}(95 \% \mathrm{Cl})=1.44(0.98-2.11)$ & $\begin{array}{l}\text { Forty-four individual level covariates, } \\
\text { including income, race and SES }\end{array}$ \\
\hline $\begin{array}{l}\text { Krewski } \\
\text { et al. }\end{array}$ & $\begin{array}{l}\text { United } \\
\text { States }\end{array}$ & $1,200,000(1999-2000)$ & $\mathrm{PM}_{2.5}\left(10 \mu \mathrm{g}\right.$ per $\left.\mathrm{m}^{3}\right)$ & $\mathrm{HR}(95 \% \mathrm{Cl})=1.142(1.057-1.234)$ & $\begin{array}{l}\text { Forty-four individual level covariates, } \\
\text { including income, race and social } \\
\text { factors }\end{array}$ \\
\hline \multirow[t]{3}{*}{ Pope et $a l^{3}{ }^{3}$} & \multirow{3}{*}{$\begin{array}{l}\text { United } \\
\text { States }\end{array}$} & $1,200,000(1979-1983)$ & $\mathrm{PM}_{2.5}\left(10 \mu \mathrm{g}\right.$ per $\left.\mathrm{m}^{3}\right)$ & $\operatorname{RR}(95 \% \mathrm{Cl})=1.08(1.01-1.16)$ & \multirow{3}{*}{$\begin{array}{l}\text { Age, sex, smoking status, marital } \\
\text { status, education, occupational } \\
\text { exposure, race, BMI, alcohol } \\
\text { consumption and diet }\end{array}$} \\
\hline & & $1,200,000(1999-2000)$ & $\mathrm{PM}_{2.5}\left(10 \mu \mathrm{g}\right.$ per $\left.\mathrm{m}^{3}\right)$ & $\operatorname{RR}(95 \% \mathrm{Cl})=1.13(1.04-1.22)$ & \\
\hline & & $1,200,000(1982-1998)$ & $\mathrm{PM}_{2.5}\left(10 \mu g\right.$ per $\left.\mathrm{m}^{3}\right)$ & $\operatorname{RR}(95 \% \mathrm{Cl})=1.14(1.04-1.23)$ & \\
\hline \multirow{3}{*}{$\begin{array}{l}\text { Turner } \\
\text { et al.10 }\end{array}$} & \multirow{3}{*}{$\begin{array}{l}\text { United } \\
\text { States }\end{array}$} & $188,699(1979-1983)$ & $\mathrm{PM}_{2.5}\left(10 \mu \mathrm{g}\right.$ per $\left.\mathrm{m}^{3}\right)$ & $\mathrm{HR}(95 \% \mathrm{Cl})=1.15(0.99-1.35)$ & \multirow{3}{*}{$\begin{array}{l}\text { Age, sex, passive smoking, marital } \\
\text { status, education, occupational } \\
\text { exposure, race, BMI, diet, prevalent } \\
\text { lung disease and radon exposure }\end{array}$} \\
\hline & & $188,699(1999-2000)$ & $\mathrm{PM}_{2.5}\left(10 \mu \mathrm{g}\right.$ per $\left.\mathrm{m}^{3}\right)$ & $\operatorname{HR}(95 \% \mathrm{Cl})=1.27(1.03-1.56)$ & \\
\hline & & $188,699(1982-2008)$ & $\left.\mathrm{PM}_{2.5}(10 \mu g \text { per m })^{3}\right)$ & $\operatorname{HR}(95 \% \mathrm{Cl})=1.19(0.97-1.47)$ & \\
\hline \multicolumn{6}{|l|}{ Asia } \\
\hline Caoet al. ${ }^{33}$ & China & $70,947(1991-2000)$ & $\mathrm{SO}_{2}\left(10 \mu g\right.$ per $\left.\mathrm{m}^{3}\right)$ & $\Delta M(95 \% C l)=4.2(2.3-6.2)$ & $\begin{array}{l}\text { Age, sex, smoking status, education, } \\
\text { BMI, alcohol consumption, physical } \\
\text { activity and hypertension }\end{array}$ \\
\hline \multirow{3}{*}{$\begin{array}{l}\text { Kantanoda } \\
\text { et al. }{ }^{34}\end{array}$} & \multirow[t]{3}{*}{ Japan } & \multirow[t]{3}{*}{$63,520(1974-1983)$} & $\mathrm{PM}_{2.5}\left(10 \mu \mathrm{g}\right.$ per $\left.\mathrm{m}^{3}\right)$ & $\operatorname{HR}(95 \% \mathrm{Cl})=1.23(1.09-1.38)$ & \multirow{3}{*}{$\begin{array}{l}\text { Age, sex, smoking status, diet and } \\
\text { indoor charcoal or briquette braziers } \\
\text { used for heating }\end{array}$} \\
\hline & & & $\mathrm{SO}_{2}\left(10 \mu g\right.$ per $\left.\mathrm{m}^{3}\right)$ & $\operatorname{HR}(95 \% \mathrm{Cl})=1.19(0.97-1.45)$ & \\
\hline & & & $\mathrm{NO}_{2}\left(10 \mu\right.$ ger $\left.\mathrm{m}^{3}\right)$ & $\operatorname{HR}(95 \% \mathrm{Cl})=1.15(1.06-1.24)$ & \\
\hline $\begin{array}{l}\text { Yorifuji } \\
\text { et al. }\end{array}$ & Japan & $14,001(1999-2009)$ & $\mathrm{NO}_{2}\left(10 \mu g\right.$ per $\left.m^{3}\right)$ & $\mathrm{HR}(95 \% \mathrm{Cl})=1.20(1.03-1.40)$ & $\begin{array}{l}\text { Age, sex, smoking status, BMI, } \\
\text { hypertension, diabetes, financial } \\
\text { capability and area mean income }\end{array}$ \\
\hline
\end{tabular}



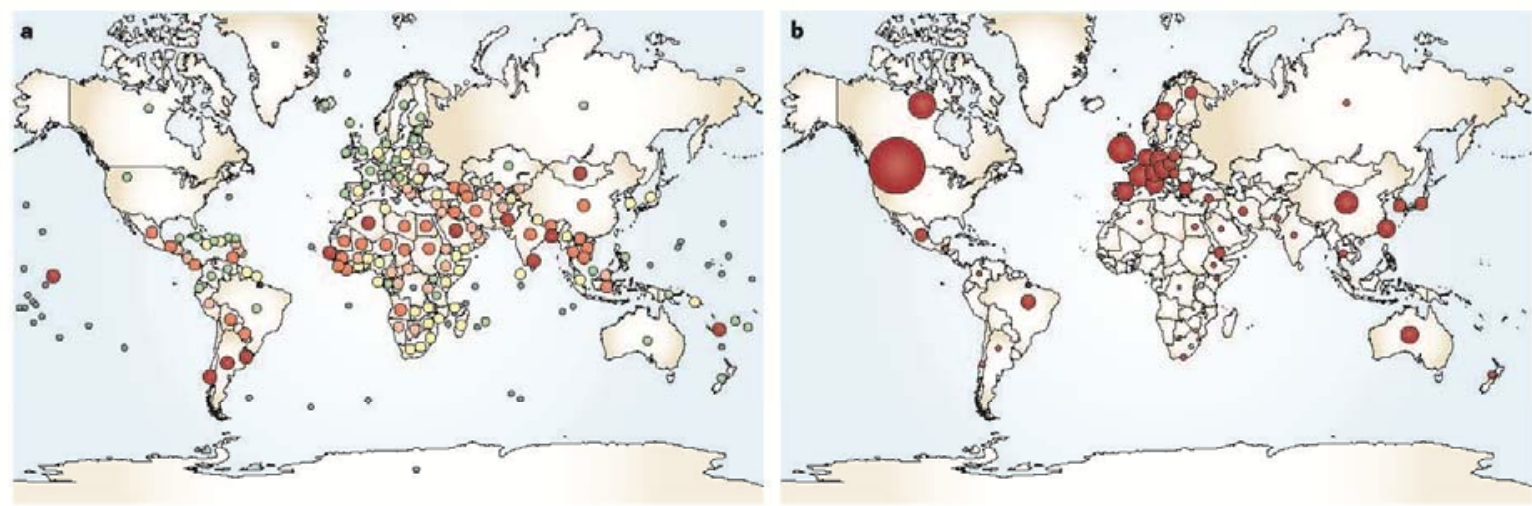

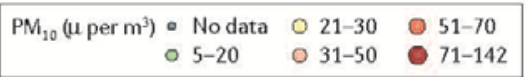

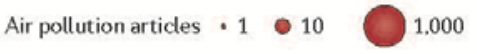

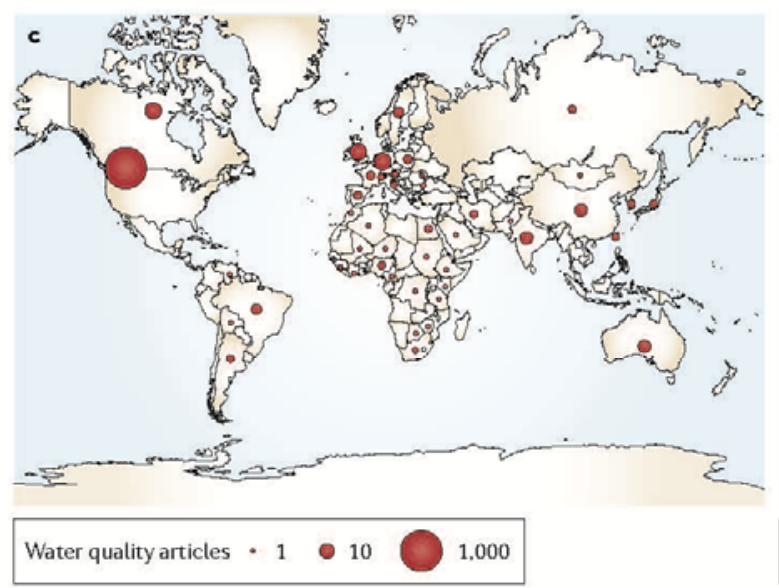

Figure 2 | A comparison of scientific research output on various global health issues. Global annual mean $\mathrm{PM}_{10}$ (particulate matter with a median aerodynamic diameter of less than $10 \mu \mathrm{m}$ ) concentration ( $\mu$ g per $\mathrm{m}^{3}$ ) in 2009 (part a) ${ }^{49}$. Number of articles in environmental public health published between March 1983 and March 2013 on ai

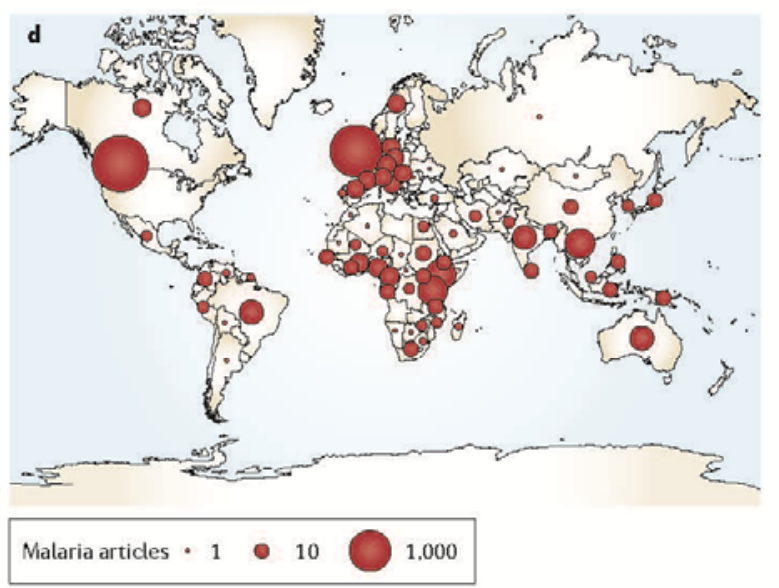

pollution (part b), water quality (part c) and malaria (part d), according to data from the Web of Science database. Search terms used were air pollution (part b), water quality (part c) and malaria (part d). The public environmental and occupational health filter was used for all searches. of pollution, as a substantial proportion of outdoor air pollution may derive from poor household fuel combustion, particularly in $\mathrm{Asia}^{44}$.

\section{Science-based control of air pollution?}

Theoretically, good scientific research is necessary to provide the basis for the implementation of policies that aim to control harmful environmental agents, helping society to decide a course of action once the apparent dilemma between preservation of human health and economic growth becomes more widely appreciated. In fact, governments that have a greater expenditure on health care have more stringent air quality standards, probably because of greater governmental awareness of the adverse health effects of air pollution and the consequent establishment of air pollution control measures to avoid increased health $\cos \mathrm{s}^{42}$. In this context, it would be interesting to know whether there is enough scientific research in air pollution hot spots to drive public policies that aim to reduce the problem. FICURE 2 depicts a comparative panel of the number of papers produced from 1983 to date on malaria, water quality and air pollution, using the Web of Science database. There is a marked imbalance between levels of air pollution and local scientific production: a more balanced scenario emerges when waterborne diseases and malaria are considered. Developing res of the world countries contribute to almost
$20 \%$ of all the research on water quality and to approximately $70 \%$ of the research on malaria, but to only $5 \%$ of all air pollu tion papers. A 2012 report from the World Meteorological Organization ${ }^{25}$ about the effects of megacities on air pollution and climate identified 11 international collaborative research projects, but only $50 \%$ focused on developing regions.

\section{Conclusions and future directions}

Sources of air pollution are unequivocally linked to economic activities; therefore, it is important to devise strategies to increase the collaboration between developed and developing nations to address the health effects of air pollution. Gains in scientific 


\section{PERSPECTIVES}

knowledge and global partnerships were effective in reducing the cancer risks associated with other environmental health issues, such as tobacco smoke and asbestos. Is now the time to do the same for air pollution?

Lais Fajersztajn. Mariana Veras and Paulo Saldiva are at the Laboratory of Experimental Air Polfution (LMO5), Department of Pathology. School of Medicine, University of Sào Pauto, Sao Pauto 01246-903. Sào Paulo State, Brazit.

Ligia Vizeu Barrozo is at the Department of Geography. Schoot of Philosophy, Literature and Human Sciences, University of Sào Pauio. Sào Pauto 05508-009 Sào Pauto State, Brazit. Correspondence to P.S. email: pepino@usp.br do: 10.1038/nrz3572 Published online 8 August 2013

1. Lim, S. S. et al. A comparative risk assessment of actors and risk factor clusters in 21 regions. 990-2010: a systematic analysis for the Clobal 2224-2260 (2012)

2. Clancy, L, Goodman, P. Sinclair, H. $\bar{Q}$ Dockery, D. W. Effect of airpollution contmol on death rates in Dublin. reland: an intervention study. Lancet 360 . $1210-1214(2002)$.

3. Pope, C. A . et al. Lung cancer, cardiopulmonary mortality and long term exposure to fine particulate air pollution. JAMA. 287, 1132-1141 (2002).

4. Pope, C.A., Ezzati, M. \& Dockery, D.W. Fine particulate air pollution and life expectancy in the United States.
New Engl. J. Med. 360. 376-386 [2009).

5. Lepeule, J., Laden, F., Dockery, D. \& Schwartz, J. Chronic exposure to fine particles and mortality: an extended follow-up of the Harvand six cities study from
1974 to 200 . Environ. Health Persp. 120, 965-970 1974 to
$[2012]$.

6. Vineis, P. et af. Lung cancers attributable to environmental tobacco smoke and air pollution in nonenvironmental tobacco smoke and air pollution in nonstudy. Environ. Health 6, 1-7 (2007). 7. Vineis, P. et al. Genetic susceptibility accond ing to bladder and in myeloid leukemias in nonsmokers Ann Oncel. $18,1230-1242(2007)$

8. Fang, Y., Naik, V., Horowitz, L. W. \& Mauzerall, D. L. Air pollution and associated human mortality: the role of air pollutant emissions, climate change and methane concentration increases from th preindustrial period to present. Atmos Chem. Phys. $13,1377-1394(2013)$

9. Krewski, D. et al. Extended follow-up and spatial analysis of the American Cancer Society study linkin particulate air pollution and mortality. Res Resp. Health Eff. Inst. 5-114 2009$]$

10. Tumer, M. C. et al. Long term ambient fine particulate matter air pollution and lung cancer in a lange cohor of neversmokers. Am. J. Respir. Crit Core Mod. 184,

11. Pope. C. A et al. Lung cancer and cardiovascular disease mortality associated with ambient air polsponos relationships. Environ. Health Perspect 119 1616-1621 (2011).

12. Evans, J. et al. Estimates of global mortality attributable to particulate air pollution using catellite imagery. Environ. Res. 120, 33-42 (2013).

13. Crouse, D. L.. Goldbere. M. S. Ross, N. A. Chen, H. Q Labreches, F. Postmenopausal breast cancer is associated with exposure to traffic-related air pollution in Montreal, Canada: a case-control study. Environ. Health Persp. 118, 1578-1583 (2010).
14. Chen, F. Q Bina, W. F. Cornelation of white female breast cancer incidence trends with nitrogen dickide Breast Cancer Res Treat. 132, 327-333 (2012].

15. Nie, J. et al. Exposure to traffic emissions throughout life and risk of breast cancer: the Western New York Exposures and Breast Cancer (WEB) study. Cancer

16. Wei, Y., Davis, J. \& Bina, W. F. Ambient air pollution is associated with the increased incidence of breast (2012).

17 Whitworth, K. W. Symanski, E. Coker, A. L Childhood lymphohematopoietic cancer incidence and hazardous air pollutants in southeast Texace 1995-2004. Environ.

18. Weng, H. H. Tsai, S. S. Chiu, H. F. Wu, T.N. \& Yang. C. Y. Childhood leukemia and traffic air pollution in Taiwan: petnol station density as an indicator. Toxicol Environ. Health A 72,83-87 (2009).

19. Liu, C. C., et al. Ambient exposure criteria pollutants risk death from bladder cancer Taiwan. Inhal. Toxicol 21. 48-54 (2009)

20. Castaño Virnyals, $G$. et al. Air pollution and risk of uninary bladder cancer in a casecontrol study in

Spain. Occup. Environ Med 65, $56-60(2008)$

21. Tsai, S. S., Tiao, M. M., Kuo, H. W., Wu, T. N. ॄ. Yang, C. Y. Association of bladder cancer with residential exposure to petrochemical air pollutan emissions in Taiwan. J. Toxical. Environ. Health $A 72$

22 Colli, J Lee, B. R. \& Thomas, R. Population densities in relation to bladder cancer mortality rates in America from 1950 to 1994. Int Urol. Nephrol. 44 443-449 (201)

23. OECD Environmental outlook to 2050; the consequences of inaction. The Onganisation for Economic Cooperation and Development lonlinel. Economic cooperation and Development lonline, ourlookto 205 otheconseguencessfinaction htm (2012).

24. Wilkinson, P., Smith, K. R., Beevers, S., Tonne, C. \& Oreszczyn, T. Energy and Health $4:$ Energy, energy efficiency, and the buit environment Lancet. 370 $1175-1187(2007)$

25. WMONICAC. Impacts of Megacities on Air Pollution and Climate [online], hetto:/lwoww.wmo int/pages/pmat

26. James, W., Jia, C. Q Kedia, S. Uneven magnitude of disparities in cancer risks from air toxics. Int J. Environ. Res. Publ. Health. 9, 4365-4385

Bellen, R. et al. Long-term exposure to traffic-related air pollution and lung cancer risk. Epidemiology. 19,

28 Brunekreef, B. trufficrelated air pollution on respiratory and
cardiovascular mortality in the Netherlands: the cardiovascular mortality in the Netherlands: the (2009).

29. Cesaroni, G. et al. Longterm exposure to urban air pollution and mortality in a cohort of more than a million adults in Rome. Environ. Health Persp. 121 324-331 (2013)

30. Heinrich, J. et al. Long.term exposure to NO2 and PM10 and all-cause and cause-specfip mortality in prospective cohort of women. Occup. Environ. Med.

31. Dockery, D. W. et al. An association between air pollution and mortality in six US cities. New Eng

32. Jerret, M. et al. Spatial analysis of air pollution and $16,727-736$ (2005)

33. Cao, J. et al. Association between long term china 1594-1600 (2011).

34. Kantanoda. K. et al. An association between long-tern exposure to ambient air pollution and mortality from lung cancer and nespiratory diseases in Japan
J. Epidemiol. 21, 132-143 [2011).
35. Yorifuji, T. et al. Long-term expousure to trafficreelated air pollution and the risk of death from hemorrhagic stroke and lung cancer in Shizuoka, Japan. Sci. Tot Environ. 443, 397-4,02 (2013)

36. Health Effects Institute. Understanding the Healt th fffects of Components of the Particulate Matter Mix Progress and Next Steps. (HEl, 2002)

37. Pope, C. A. \& Dockery, D. W. Health effects of fine particulate air pollution: lines that connect. S. Air Waste. Manag. Assoc. 56, 709-742 (2006).

38. Benbrahim-Tallaa, L. et al. Carcinogenicity of dieselengine and gasoline-engine exhausts and some

39. Beckerman, B. et al. Correlation of nitrogen dioxide with other traffic pollutants neara major expressway. Atmospher Environ. 42, 275-290 (2008).

40. Van Erp, A. M., O'Keefe, R., Cohen, A. J., Warren, J. Evaluating the effectiveness of air quality
interventions. J. Toxicol. Environ. Health A 71 . 583-587 (2008)

41. World Health Organization. Air quality ouidelines: global update 2005. (WHO, 2006)

42. Vahising, C. \& Smith, K. R. Clobal review of nationa ambient air quality standards tor $\mathrm{PM} T \mathrm{~T}$ and $\mathrm{SO} 2$ (24 hi). Air Qual. Atmos. Health 5, 393-399 (2012)

43. Companhia Ambiental do Estado do Sä Paulo. Qualidade do ar no estado de Såo Paulo 2012.

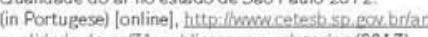
Suatidadedo-ar 31 - publicacoesserelatorios (2013). Smith, K. R. et al. Energy and Human He
Rev. Publ. Health 34, 159-188 (2013).

45. Coal Industry Advisory Board. Power generation from coal measuring and reporting efficiency performance

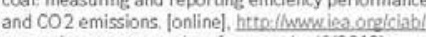
papers/ocower peneration from coal. Ddf $(2010)$.

46. EURACOAL. Coal Industry across Europe. Ionline].

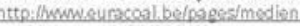
php? idnage - 917 (2013)

47. Wilkinson, P., Smith, K. R. Beevers, S., Tonne, C. \& Oreszczyn, T. Energy and Health 4: Energy, energy efficiency, and the bu

48. Markandya, A. $\bar{Q}$ Wilkinson, P. Energy and Health 2 Electricity generation and health. Lancet 370 . 979-990 (2007)

49. World Bank. Population density (people per sq. km of land areal. Ionline]. hitto: illdato worldbank orel value 2010 + wbapi data value + wbapi data value

50. World Bank. PM10, country level (micrograms per cubic meter). Ionlinel, hetroild data worldbankengl idicatoriEN. ATM. PM 10.MC.M3? onder - wbabi data astisoct-desc (2012).

51. Raaschou-Nielsen, $O$. et af. Air pollution and lung cancer incidence in 17 Eumpean analyses from the European Study of Cohors for Air Pollution Effects (ESCAPE, hitrolldx doi orol10 1016 51470-2045113170279-1 (2013)

\section{Acknowledgements}

This work was partly supported by grants inumber 573813/2008-6) from CNPq [Consetho Nacional de Desenvorvimento Clentificoe Tecnologicol and by grant (number 12/19266-8) from FA.PESP (Fundaçăo de Amparo Pesquisa do Estado de Săo Paulol. P.S.. L.V.B. and L.F. devel. oped the ideas in the article. L.F. and L.V.B. designed the maps. L.F. and M.V. carned out the literature revien, and L.F. M.V.L.V.B. and P.S. wrote the article. The authors collected the relevant literature on cancer effects and air pollution by seanching the Web of Science database for papers published from 1981 to date using the terms air pollution and cancer. and by applying the public environmental and occupational

Competing interests statement

The authors declare no competing financial interests.

DATABASES

Web of Seience: http://thomsanre sutern com/web-ofacience/ ALL UINKS ARE ACTIVE IN THE ONLINE PDF 
4.1.2. Co-benefícios para a saúde advindos de politicas de baixo carbono no setor de transportes

Este manuscrito combina propriedades de um estudo e de uma narrativa e pretendeu apontar as desigualdades dos efeitos dos poluentes sobre a saúde sob a ótica da defasagem tecnológica entre países em desenvolvimento e países desenvolvidos. Usei dados secundários para mostrar visualmente a razão entre consumo de energia per capita (expresso pelas emissões per capita de $\mathrm{CO}_{2}$ ) e concentração média de poluição local (expressa pela concentração média anual de $\mathrm{MP}_{10}{ }^{*}$ ) por país. Esse conceito foi apresentado no Congresso da Sociedade Internacional em Epidemiologia Ambiental realizado em São Paulo em 2015 e publicado na forma de resumo ${ }^{(56)}$. Para o manuscrito, construí uma narrativa focada na América Latina e nos potenciais co-benefícios para a saúde populacional da região resultantes da adoção de políticas de baixo carbono no setor de transportes, particularmente melhor eficiência energética nos processos de combustão do setor de transportes. O manuscrito está em fase final de submissão e é apresentado a seguir, logo após apresentação do resumo apresentado na Conferência da Sociedade Internacional de Epidemiologia Ambiental.

\footnotetext{
${ }^{*} \mathrm{MP}_{10}$ refere-se ao poluente atmosférico material particulado com diâmetro aerodinâmico menor que 10 micrômetros.
} 
Resumo apresentado em Conferência.

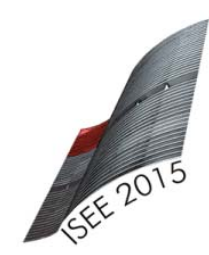

$27^{t}$ Conference of the International Society for Environmental Epidemiology:

Addressing Environmental Health Inequalities. São Paulo, Brazil.

Program Oral Session - 02/09/2015 - 16h00-17h30 Air pollution and environmental justice

\section{7 - IMPROVING ENERGETIC EFFICIENCY IN DEVELOPING ECONOMIES: OPPORTUNITIES TO REDUCE GLOBAL HEALTH DISPARITIES}

Laís Fajersztajn ${ }^{1}$, Ligia Vizeu Barrozo ${ }^{2}$, Mariana Matera Veras ${ }^{1}$, Yuming Guo ${ }^{3}$, Micheline De Sousa Zanotti Stagliorio Coelho ${ }^{1,4}$; Paulo Hilário Nascimento Saldiva ${ }^{1}$.

1.Laboratory of Experimental Air Pollution (LIM 05), Department Of Pathology, School of Medicine, University Of São Paulo, São Paulo, Brazil.

2. Department of Geography, School of Philosophy, Literature and Human Sciences, University of São Paulo, Brazil.

3. Division of Epidemiology and Biostatistics, School of Public Health, University of Queensland, Brisbane, Australia.

4. Centre for Air Quality and Health Research and Evaluation, Australia.

Decarbonitization policies seem to have different size-effect on local health benefits, according to the development stage of the nation. High technological efficiency contributes to improvements in fossil fuel combustion process, reducing both greenhouse gas (GHG) and local pollutants emissions. The health gains are likely to benefit more people living in developing countries, where inefficient combustion technologies and bad air quality preponderate. Despite evaluations from the economic perspectives, no study has examined the role of technological inefficiency in global health inequality. In this study, we developed a global index to verify the magnitude of the technology inefficiency of energy production processes in the inequality burden of air pollution exposure. Methods. The index is the ratio of local air pollution level to GHG emissions by country: PM10/CO2. (Indicators: annual mean concentration of particulate matter of $10 \mu \mathrm{m}$ or less in micrograms per cubic meter (PM10) and carbon dioxide (CO2) emission in metric tons per capita from manufacture of cement and burning of fossil fuel). We examined the 
Sperman correlations between the index and the development status of the country (indicators: Gross National Income per capita, Atlas method (GNI), Human Development Index (HDI)), and the life expectancy. We also addressed the index trends from 1991 to 2010. Data were collected from the World Bank and The United Nations Development Program. Results. The index correlated significantly $(\mathrm{p}=0.001)$ with life expectancy $(\mathrm{r}=-0.738)$, GNI $(\mathrm{r}=-0.883)$, and HDI $(\mathrm{r}=-0.868)$. The index trends indicate that developing economies decrease the ratio more rapidly than developed ones, but they are still far from the international standards for local pollutants. Conclusions. The index underlines that, improving technological efficiency in developing economies may be in an instrument to reduce global health inequalities from air pollution exposure. 
Artigo em processo de submissão.

\section{Combining low carbon transportation polices and human health: a global overview focused in Latin America.}

Laís Fajersztajn†, Mariana Veras†\#, Paulo Saldiva $\dagger^{*}$

$\uparrow$ Laboratory of Experimental Air Pollution (LIM05), Department of Pathology, School of Medicine, University of São Paulo

\#Surgery Department, School of Veterinary Medicine and Animal Science, University of Sao Paulo

*IEA- Institute for Advanced Studies of the University of Sao Paulo

\section{Abstract}

The transport sector leads $(37 \%)$ the dioxide carbon $\left(\mathrm{CO}_{2}\right)$ emissions from fossil fuel combustion in Latin America, and thus is an important focus of climate change mitigation. Low carbon polices in the transport sector yield large, immediate public health benefits due to their potential to reduce air and noise pollutants. Health net gains also emerge from the potential to reduce the risk of traffic-related injuries, to increase physical activity levels, among others. Despite the decrease in the growth of emissions rates, developed economies are still major $\mathrm{CO}_{2}$ emitters, compared to all Latin American countries. At the same time, the quality of the air is usually better in the developed major $\mathrm{CO}_{2}$ emitter countries, compared to most of Latin American countries. The mismatch might be a reflection of differences in technology of fossil combustion process. Improved technologies -highly prevalent in developed economies- release less particulates per $\mathrm{CO}_{2}$ emissions, benefiting health. We proposed a global index that underline the contribution of technological inefficiency for the bad air quality in developing countries (Latin America inclusive), despite relatively lower GHG emissions. Given the high burden for health of ambient pollutant, the index might reflect health inequalities from technological inefficiency in fossil fuel combustion processes. Compare to the world, air quality and $\mathrm{CO}_{2}$ emissions in Latin America figure in an intermediary scenario and there is room for improvements. Latin America is a highly urbanized continent, where many cities combine elevated levels of air pollutants, 
large numbers of exposed people and relatively less stringent emissions standards for the transport sector, enhancing the health benefits of low carbon transportation polices. Transportation polices should be considered an environmental and a health police.

Key words: climate change, global climate change, air pollution, air quality, health, Latin America, $\mathrm{CO}_{2}$ emissions, particulate matter, low carbon policy, environmental policy, health policy

\section{Low carbon transportation can tackle climate change and improve health}

Limiting climate change requires substantial and sustained reductions of greenhouse gas (GHG) emissions, particularly carbon dioxide $\left(\mathrm{CO}_{2}\right)$ emissions, $90 \%$ of the total anthropogenic GHG emissions in 20101. The transport sector leads (37\%) the $\mathrm{CO}_{2}$ emissions from fossil fuel combustion in Latin America ${ }^{2}$, and thus is an important focus of climate change mitigation in the region.

Low carbon polices in the transport sector yield large, immediate public health benefits.

In part because these polices reduce GHG emissions and local ambient air pollutants levels (responsible for 4.3 million deaths in 20123) at the same time. Health net benefits also emerge from potentially traffic-related reductions in noise levels, risks for injuries, physical inactivity levels, among others ${ }^{4}$.

Environmental, transportation and health policies are usually segregated by distinct sectors in urban administrations. However cities are complex and dynamic systems and all sectors influence each other. Decision-making for the best well-being of population and natural systems depends on overcoming segmentation. In this article we depict scientific evidence from several research areas to explain why transportation should also be considered an environmental and a public health police. Moreover, we propose a global index to highlight the higher burden of air pollution for developing and relatively low $\mathrm{CO}_{2}$ emitter economies, compare to developed relative high $\mathrm{CO}_{2}$ emitter ones.

\section{GHG emissions and local particulate pollution in the world and in Latin America.}

Cumulative emissions of $\mathrm{CO}_{2}$ largely determine global mean surface warming and are already impacting natural and human systems all over the world ${ }^{1}$.The energy sector contributed with $68 \%$ of the anthropogenic GHG emissions in 2010, most of each 
resulting from the oxidation of carbon in fuels during combustion. In 2013, the transport sector leaded the $\mathrm{CO}_{2}$ emission from fossil fuel combustion (37\%) in Latin America ${ }^{2}$.In other regions of the world, electricity and heat production were the major contributors sectors, but transportation also played a relevant role: $28 \%$ in developed countries, $23 \%$ in Middle East countries and 8\% in China $^{2}$.

According to climate scientists, tackling climate change safely will require near zero emissions of $\mathrm{CO}_{2}$ by the end of the century and substantial emissions reductions from all sectors -transport inclusively- over the next few decades ${ }^{1}$. However the world total $\mathrm{CO}_{2}$ emissions increased $56 \%$ between 1990 and $2013^{1}$. The rise of developed countries was far smaller, compared to developing nations (9\% against $112 \%)^{1}$. Fewer population growth, more stringent emission standards and improvements in combustion technology explain in part the decrease in emissions rates. Latin American increase (104\%) was slightly below developing countries mean, but smaller than Middle East and China rise $(208 \% \text { and } 307 \% \text { respectively })^{2}$. Low carbon policies for the transport sector are crucial to revert the risen trend and meet $\mathrm{CO}_{2}$ reductions targets, particularly in Latin America. Hence, some polices encompasses net benefits for health and for the economy.

Particulate matter is a complex mixture of solid and liquid components, usually classified according to their size as coarse $\mathrm{PM}_{10}$ (ranging from $10 \mu \mathrm{m}$ to $2.5 \mu \mathrm{m}$ in diameter) and fine $\mathrm{PM}_{2.5}$ (smaller than $2.5 \mu \mathrm{m}$ in diameter $)^{5}$. The composition and size of the particles are determined by the emission source and prevailing weather condition $^{5}$. The smaller the size of the particle, the greater its potential to penetrate deep into the respiratory tract and the more severe its impacts for health ${ }^{6}$. The composition of particulates includes different classes of organic and inorganic chemicals, with different known toxicological effects for health ${ }^{5}$, but have being widely used as an indicator of the real world exposure to air pollutants. Despite the variance in its composition, in 2013 the International Agency of Research on Cancer classified the particulate matter from outdoor air pollution carcinogenic for humans.

Long-term effects of air pollution for health also includes chronic pulmonary obstructive disease. Short-term exposure to particulates adversely affects mortality ${ }^{3-4,6-7}$ and morbidity ${ }^{4}$, notably from cardiovascular and respiratory causes in vulnerable populations (elderly, children, pregnant women, people with an existing chronic disease and low income populations). Endocrine, neurocognitive and other systems are also 
negatively affected by particulates.

Developing countries depict higher levels of particulate pollution, compared to developed countries ${ }^{9}$. The highest concentrations are in Asia ${ }^{9}$. Latin America figures in an intermediary scenario ${ }^{9}$. This picture reflects differences in the burden of disease due to air pollution exposure among different regions of the world ${ }^{3}$. In 2012, 3.7 million premature deaths were attributable to ambient air pollution globally, 936 thousands occurred in South-East Asia, 176 thousands in Africa, 58 thousands in Latin America and 14 thousands in high income countries of the Eastern Mediterranean ${ }^{3}$.

\section{Technological inefficiency as a driver of higher burden of air pollution-related diseases.}

Oxidation of carbon in fuels during combustion is a major contributor of the GHG emissions $^{2}$. However, the particulate matter released -which impairs health-, depends on the quality of the combustion process. Driven by more stringent emission standards, developed countries are progressively shifting to lower-emissions vehicles that yield less particulate pollution. Older more polluting vehicles are being exported to developing country markets, where regulatory controls on fuels and vehicle maintenance are usually less strict ${ }^{4}$. As a result, particulate matter concentrations, and the health burden from them, are usually higher in low and middle income economies, compared to developed ones. Moreover, developing regions are undergoing a rapid urbanization and population growth, exposing more people to the health burden of air pollution.

Some studies, have evaluated the economic effects of technological improvements in motor vehicles, but its impact on health and equity are barely mentioned. High local particulate levels per $\mathrm{CO}_{2}$ emission might reflect the technologic inefficiency of fossil fuel combustion processes in developing economies. We propose a global index to underline the contribution of technological inefficiency of fossil fuel combustion for the bad air quality, despite relatively low GHG emissions levels. Given the high burden for health of ambient pollutant ${ }^{3-5,6-7}$, the index might reflect health inequalities from inefficiency of fossil fuel combustion process. The index is the ratio of local air pollution level (indicator: national mean concentration of coarse particulates ${ }^{8}$ ) to $\mathrm{GHG}$ emissions (indicator: $\mathrm{CO}_{2}$ emissions per capita ${ }^{9}$ ) by country, or $\mathrm{PM}_{10} / \mathrm{CO}_{2}$. The human 
developing index was used to address developing stages of the countries ${ }^{10}$. For the same amount of energy consumption (expressed by $\mathrm{CO}_{2}$ emissions), low and middle income countries tended to emit more local particulate pollutants, compared to high income economies (Figure 1). In Latin America the index is higher compared to high income economies and lower compared to low and middle income ones (Figure 2). Given the high burden for health of ambient air pollution ${ }^{3,6}$, improving technological efficiency of fossil fuel combustion in developing economies may be in an instrument to reduce global health inequalities. Low carbon transportation polices would greatly benefit environment and human health in the Latin America Latin, where the transportation is the major emitter sector.

\section{Low carbon transportation polices and health}

Health benefits related to the reduction in air pollution levels

Lower levels of air pollution have positive impacts in mortality and morbidity rates and largely explain the mechanisms of the health co-benefits of low carbon transportation polices. A study conducted in nine Latin American cites found small but significant short-term effects of $\mathrm{PM}_{10}$ levels on mortality ${ }^{7}$, consistent with European and North American studies. Local evidence on fine particulate and long-term effects of air pollution is scarce in the region.

Stringent restrictions on motor vehicle use imposed during the Beijing Olympics, reduced fine and coarse particulate concentrations by $31 \%$ and $35 \%$ respectively ${ }^{11}$.Asthma outpatient visits dropped nearly $50 \%{ }^{11}$ and the birth weight of full-term babies increased significantly ${ }^{12}$. Low carbon transportation polices related to local air pollution reductions include active transportation, smart land use, rapid public transportation and fuels choices (sources and emissions standards) ${ }^{4,13}$.

Active transportation (travel by foot and/or bicycle on their one, or as part of a public transport journey) reduces air pollution because it reduces themiles travelled by private motorized vehicles ${ }^{4,13}$. In five Latin American cities (Cidad de México, Rio de Janeiro, São Paulo, Buenos Aires and Santiago), bike-shearing programs increased the number of cyclists ${ }^{15}$. Bike paths increased bicycle trips in Rio de Janeiro, Lima and Bogotá ${ }^{4,15}$. Land-use policies that reduce the distance of trips and restrict motor vehicle 
concentrations depicted similar effects ${ }^{4,13}$.An aesthetically pleasing walking environment can favour the adoption of active transportation, strength social support networks, and potentially mitigate heat waves from climate change, if combine with a densely green coverage $e^{4,13}$.

Air pollution concentrations differ by public transport mode. Levels are higher in diesel bus, followed by subways and tram. Within subways, closing the window of the trains reduce air pollution exposure. Time of the journey is as important as concentration to determine human exposure to air pollutants. In Latin America, Bus Rapid Transit systems (BRT) were implemented in six $\operatorname{cities}^{4,14}$ and also might be contributing to increase physical activity levels among those living close to BRT stations ${ }^{4,14}$.

Although diesel vehicles have potential to reduce transport-related $\mathrm{CO}_{2}$ emissions, diesel engines emit more particulates ${ }^{4}$. Diesel encompasses adverse health effects, not health co-benefits. Improvements in diesel engines in Europe resulted in stable, but not lower particulate level.

Health benefits related to a reduction in noise pollution

Physiological responses of traffic-related noise include rises in stress levels and blood pressure. High traffic-related noise levels are associated with cardiovascular diseases ${ }^{4,13}$ and sleep disturbance ${ }^{4,13}$, imposing increased risk for mental ilness ${ }^{4,13}$. Low carbon transportation polices linked to traffic-related noise reduction, include transport and land use polices that reduce traffic speed and volume. Specific road materials also play a role. Porous asphalt can reduce noise level, equivalent to almost halving the volume of traffic $^{15}$

Health benefits related to a reduction in road traffic injuries

Road traffic injuries is a largely predictable and preventable risk that lead the top risks factors for the burden of disease in Latin America ${ }^{16}$. Walkers, cyclists and motorcyclists are more vulnerable. In São Paulo and Valledupar, traffic-related injuries were more severe among motorcyclists.

Low carbon transportation polices that reduce the risk of traffic-related injuries include safe networks for active transport and reduced traffic speed, ${ }^{4,13,15}$. After two months, a $20 \mathrm{~km} / \mathrm{h}$ reduction in the limit speed for cars in a major road in São Paulo, reduced deaths and injuries in $36 \%$, with gains in traffic congestions. Rail systems also seems to 
pose lower risk for road traffic injuries ${ }^{4,15}$.

Health benefits related to an improvement in physical activity levels

Physical inactivity is the fourth leading cause of death worldwide ${ }^{16}$ and figures among the top ten risk factors for the burden of disease in Latin America and Caribbean ${ }^{17}$. Physical inactivity is one of the factors driving the global increases (in developing world inclusive) in cardiovascular disease, type 2 diabetes, overweight, obesity and some types of cancer (colon and breast) ${ }^{4,13,15-18}$. More physical activity is related to less depression, anxiety and osteoporosis ${ }^{4,13}$. In São Paulo, the proportion of children traveling to school by active transportation deceased nearly 10\% between 1997 and 2007, whereas the proportion of children traveling by private car increased in similar rates $^{19}$. While the time spent in trips to school nearly double in the period for those travelling by car, mean time duration of active transport trips to schools remained unchanged in the period ${ }^{19}$.

The major low carbon transportation police that increase physical activity levels is active transportation alone or as part of a journey ${ }^{4}$. Each additional kilometre walked per day reduces in $4.8 \%$ the risk of obesity ${ }^{18}$. Outdoor physical activity promoted by active transportation seems to encompass even more benefits for mental health ${ }^{4,13}$. Outdoor exertion promotes exposure to sunlight, increasing vitamin D levels ${ }^{4}$, but also the risk for skin cancer in tropical Latin American cities. Specific orientations for sunlight protection during the day might be necessary in Latin America. A recent review $^{20}$ concluded that the health gains of active transportation outweigh the risks imposed by traffic accidents and exposure to air pollution.

\section{Low carbon transportation polices encompasses economic and social gains}

Long journeys reduce the time for leisure, rest and work with health, social and economic consequences. Low income adolescents spent more time during journeys, because they usually live far from their jobs and have less access to public transportation. The consequent fewer time for study decrease their future job opportunities, reinforcing social inequalities. Improving mobility by public transport among groups with less access to private vehicles (women, children, elderly, people with disabilities and lower income groups) enhances access to economic and social 
opportunities, promoting equity ${ }^{4}$.

The cost of immobility in São Paulo was estimated in $1 \%$ of the Brazilian gross domestic product. A combination of BRT and active transportation infrastructure improvements in Latin America could reduce GHG emissions by $25 \%$, at a cost of US30 per tonne of $\mathrm{CO}_{2}$ reduction ${ }^{4}$. The potential reduction in local pollutant levels from a reduction in GHG emissions, already discussed, can be even greater if long-range transport of air pollutants, long demographic changes and the influence of climate change or air quality are taken in account.

\section{Latin America can widely benefit from low carbon transportation polices}

The links between transportation and health are wide and well documented ${ }^{4,13-15}$, butthere remains some distance between theory and practice ${ }^{14}$. Low carbon transportation polices reduces GHG emissions and local pollutants, while encompasses local and immediate health benefits. The international scenario of global climate chance agreements ${ }^{1,4}$ favour the adoption of more sustainable transportation modes, particularly in Latin America, where the transport sector leads $\mathrm{CO}_{2}$ emission from fossil fuel combustion ${ }^{2}$.Implementation might be cost effective. Latin America is a highly urbanized continent ( $80 \%$ of its population live in cities), where many cities combine elevated levels of air pollutants, large numbers of exposed people and relatively less stringent emissions standards for the transport sector, enhancing the health benefits of low carbon transportation polices. Transportation polices should be considered an environmental and a health police.

\section{Highlights}

\section{Latin America scenario}

- Compared to other continents, air quality and GHG emissions figure in an intermediary scenario in Latin America and there is room for improvements.

- The transport sector leads the $\mathrm{CO}_{2}$ emission from fossil fuel combustion in the region.

- Low carbon transportation polices encompasses local and immediate health benefits due to reductions in noise and air pollution levels, improvements in physical activity 
levels, among others.

- Inefficient fossil fuel combustion results in higher air pollution levels in developing economies (including Latin American cities), compared to developed economies.

- More efficient combustion technologies that release less particulate pollution per $\mathrm{CO}_{2}$ emission are already used in developed economies and could be adopted to reduce the burden of air pollution in developing economies (in Latin American cities inclusive).

- As a highly urbanized region, a large number of people are exposed to air pollutants in the continent and its related health risks.

- Better air quality would improve the health of Latin American populations.

- More than an urban planning instrument, transportation polices should also be consider an environmental and a health police. 
Figure 1.Global energetic inefficiency index. The index compares the ratio of $\mathrm{PM}_{10} / \mathrm{CO}_{2}$ among countries in 2010 to its correspondent development status. $\mathrm{PM}_{10}$ and $\mathrm{CO}_{2}$ data from the World Bank ${ }^{8,9}$. Human Development index data from the United Nations ${ }^{10}$

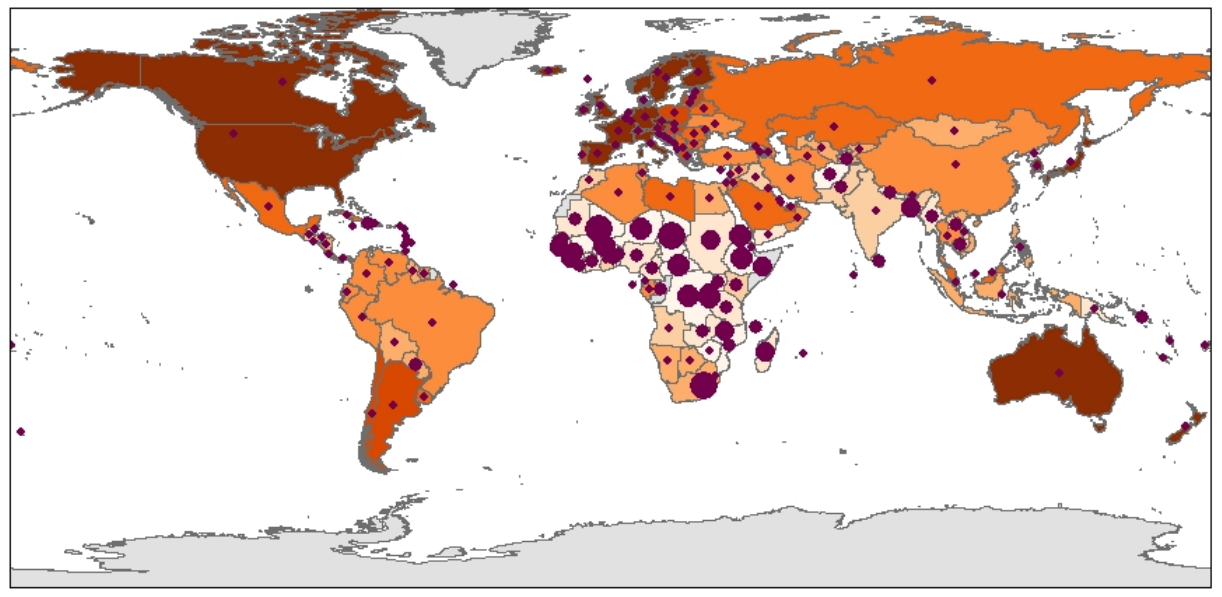

Energetic inefficiency index

(PM10/CO2)

- $0.0-66.4$

- $66.5-230.0$

- $230.1-482.6$

$482.7-1076.5$

$1076.6-4211.7$

Human Development Index

\begin{tabular}{|l|l|}
\hline$\square$ & $0.30-0.40$ \\
\hline$\square$ & $0.41-0.50$ \\
\hline$\square$ & $0.51-0.59$ \\
$\square$ & $0.60-0.68$ \\
\hline$\square$ & $0.69-0.75$ \\
& $0.76-0.81$ \\
& $0.82-0.86$ \\
& $0.87-0.96$
\end{tabular}


Figure 2. Energetic inefficiency index in selected Latin American and Caribbean countries. The graphic compares the energetic inefficiency index $\left(\mathrm{PM}_{10} / \mathrm{CO}_{2}\right)$ in 2010 in Latin American and Caribbean countries to selected high and low income countries and to the world mean. $\mathrm{PM}_{10}$ and $\mathrm{CO}_{2}$ data from the World Bank ${ }^{8,9}$. LAC represents the mean value of the index for Latin American and Caribbean countries.

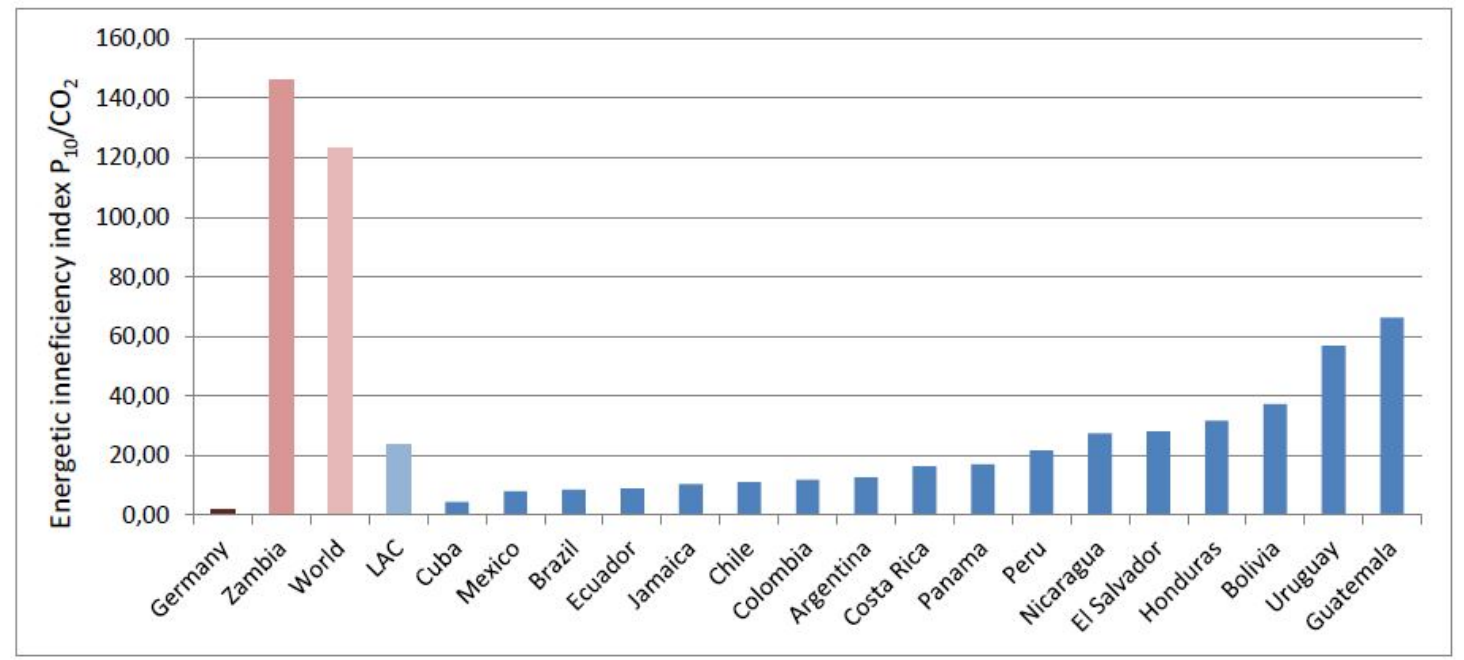

\section{Acknowledgment}

We thank Ligia Vizeu Barrozo, Micheline S.Z.S. Coelho and Yuming Guo for their comments and suggestions for the development of the global energetic inefficiency index. We thank Ligia Vizeu Barrozo for her help in developing the map used in this publication.

\section{References}

1. IPCC - INTERGOVERNAMENTAL PANEL ON CLIMATE CHANGE. 2013. Climate Change 2013: The Physical Science Basis. Contribution of Working Group I to the Fifth Assessment. Report of the Intergovernmental Panel on Climate Change Cambridge, United Kingdom and New York, NY, USA, 1535 pp. Available from:http://www.ipcc.ch/pdf/assessmentreport/ar5/wg1/WG1AR5_ALL_FINAL.pdf

2. IEA - INTERNATIONAL ENERGY AGENCY AUTONOMOUS AGENCY LINKED WITH THE ORGANISATION FOR ECONOMIC CO-OPERATION AND DEVELOPMENT. 2015. CO2 EMISSIONS FROM FUEL COMBUSTION IEA STATISTICS HIGHLIGHTS. Edition 2015. $13 \mathrm{p}$. https://www.iea.org/publications/freepublications/publication/CO2EmissionsFromF 
uelCombustionHighlights2015.pdf Accessed in march, 02nd 2016.

3. WHO - WORLD HEALTH ORGANIZATION. 2014. Burden of disease from Household and Ambient Air Pollution for 2012. Geneva, Switzerland. Available from:

http://www.who.int/phe/health topics/outdoorair/databases/FINAL HAP AAP Bo D 24March2014.pdf Accessed in Apli, $16^{\text {th }} 2014$.

4. WHO- WORLD HEALTH ORGANIZATION. 2011. Health in the green economy: health co-benefits of climate change mitigation - the transport sector. Available from:

$<$ http://www.who.int/hia/examples/trspt comms/hge transport lowresdurban $30 \quad 1$ 1 2011.pdf $>$. Acesso em 15 de janeiro de 2014

5. HEI - HEALTH EFFECTS INSTITUTE. 2002. Understanding the Health Effects of Components of the Particulate Matter Mix: Progress and Next Steps. Available from: http://pubs.healtheffects.org/getfile.php?u=244

6. POPE CA, EZZATI M, DOCKERY, DW. 2009. Fine-particulate air pollution and life expectancy in the United States. New Engl. J. Med. 360, 376-86.

7. ROMIEU I, GOUVEIA N, CIFUENTES L. 2012. Multicity Study of Air Pollution and Mortality in Latin America

(the ESCALA Study). Research Report 171. HEALTH EFFECTS INSTITUTE.

Boston, United States. Availablefrom:

http://pubs.healtheffects.org/view.php?id=389

8. World Bank. PM10, country level (micrograms per cubic meter). [online], http://data.worldbank.org/ indicator/EN.ATM.PM10.MC.M3?order=wbapi data value 2009 wbapi_data_value+wbapi_data_value-last\&sort=desc (2012).

9. World Bank. CO2, country level (metric tonnes per capita). [online], http://data.worldbank.org/indicator/EN.ATM.CO2E.PC

10. United Nations Development Programme (UNDP). Human Development Report 2010. 20th Anniversary Edition. The Real Wealth of Nations: Pathways to Human Development. New York, United States http://hdr.undp.org/sites/default/files/reports/270/hdr 2010 en complete reprint.pd $\underline{f}$

11. $\underline{\mathrm{Li}} \mathrm{Y}$, Wang W, Kan $\mathrm{H}, \mathrm{Xu} \mathrm{X}, \underline{\mathrm{Chen} \mathrm{B}}$. 2010. Air quality and outpatient visits for asthma in adults during the 2008 Summer Olympic Games in Beijing. Sci Total Environ. 408(5):1226-7.

12. HUANG C, NICHOL C, LIU Y, ZHANG Y, LIU X, GAO S, ZHIWEN L, REN A. 2015. Ambient air pollution and adverse birth outcomes: a natural experiment study. Population Health Metrics13(17):1-7.

13. GILES-CORTI B, FOSTER S, SHILTON T, FALCONER, R. 2010.The co-benefits for health of investing in active transportation. NSW Public Health Bulletin 21 (56): 112-127.

14. GOMEZ L F, SARMIENTO R, ORDOÑEZ MF, PARDO CF, DE SÁ, TH, MALLARINO $\mathrm{CH}$, MIRANDA JJ, MOSQUERA J, PARRA, DC, REIS, R, QUISTBERG DA. 2015.Urban environment interventions linked to the promotion of physical activity: a mixed methods study applied to the urban context of Latin America.SocSci Med. 131: 18-30.

15. COHEN JM, BONIFACE S, WATKINS S. 2014. Health implications of transport planning, development and operations. JournalofTransport\& Health 1: 63-72.

16. Global Burden of Disease Study 2013 Collaborators*. 2015. Global, regional, and national incidence, prevalence, and years lived with disability for 301 acute and 
chronic diseases and injuries in 188 countries, 1990-2013: a systematic analysis for the Global Burden of Disease Study 2013. Lancet 386: 743-800.

17. KOHL HW, CRAIG CL, LAMBERT EV, INOUE S, ALKANDARI JR, LEETONGIN G, KAHLMEIER S, LANCET PHYSICAL ACTIVITY SERIES WORKING GROUP. 2012. The pandemic of physical inactivity: global action for public health.Lancet 380(9838):294-305.

18. FRANK L, ANDERSEN M, SCHMID T. 2004.Obesity relationships with community design, physical activity, and time spent in cars. Am. J. Prev. Med. 27:87-96.

19. DESÁ TH, GARCIA LMT, MIELKE GI, RABACOW FM, DEREZENDE LFM. 2015. Changes in travel to school patterns among children andadolescents in the São Paulo Metropolitan Area, Brazil, 1997-2007. Journal of Transport \&Heatlh 2. 144150.

20. MUELLER N, ROJAS-RUEDA D, COLE-HUNTER T, NAZELLED A, DONSE E, GERIKEG R, GÖTSCHIH T, PANISE LI, KAHLMEIERH S, NIEUWENHUIJSENA M. 2015. Health impact assessment of active transportation: A systematic review. Prev Med. 18 (6): 103-114. 
4.2. Estudo na ausência de dados secundários sistematizados

Durante a condução do estudo sobre poluição e câncer, descrito anteriormente, notei que, de modo geral, os países em desenvolvimento tinham poucos ou não tinham estudos sobre poluição do ar e saúde. Uma das possíveis e frequentes explicações é a falta de dados locais de qualidade sobre a exposição, o que também indica ausência de condições básicas para o controle da qualidade do ar. De fato, ao contrário da maioria dos países desenvolvidos, muitos países em desenvolvimento não oferecem plataformas de livre acesso para os dados de exposição, ou não as disponibiliza de uma forma amigável, o que não necessariamente significa que não esses países dispõe de nenhum tipo de dado de monitoramento local. Como resultado, regiões em desenvolvimento são pouco representadas nas análises globais sobre poluição do ar e saúde. Sendo assim, buscamos informações sobre a cobertura do monitoramento local da poluição do ar na África, América do Sul e Oriente Médio em agências nacionais e internacionais e na literatura científica. Mesmo na escassez de dados públicos secundários sistematizados, construímos uma narrativa mostrando com números a cobertura do monitoramento da poluição do ar em países em desenvolvimento, diferenciando a completa ausência de dados da falta de dados sistematizados. Apesar de exclusivamente descritivo, o estudo recebeu o prêmio "New Voices in Global Health 2014", uma competição de resumos com o intuito de destacar pesquisas e inciativas de futuros líderes em saúde global e foi publicado no The Lancet ${ }^{(57)}$. Vide a seguir o resumo na íntegra. 
Meeting Abstracts

\section{Air monitoring coverage in low-income countries: an observational study}

Lais Fajersztajn, Mariana Veras, Ligia V Barrozo, Paulo Saldiva

\section{Abstract}

Publlshed Online Background Outdoor air pollution is among the top ten risk factors for disease and is carcinogenic for human beings.

October 19,2014 Monitoring air pollution is a fundamental requirement to implement policies to improve air quality and allow

school of Medicine scientists to more precisely quantify the risks of air pollution exposure. We assessed the coverage of air pollution monitoring in several regions.

Methods We did this observational study for Africa, Middle East and South America. We searched information about air quality monitoring coverage from international and national agencies (including WHO, World Bank, and national environmental protection agencies) and in previous scientific studies. We classified monitoring coverage as (1) campaigns (measurem ents reported in scientific publications with up to 1 year of temporal coverage or by WHO without temporal coverage reported), (2) one station (one fixed station with yearly coverage), or (3) network (more than one station with yearly coverage).

Findings In Africa, air pollution monitoring information was unavailable for $66 \%$ of countries, none was available from one station, $14 \%$ was from campaigns, and $20 \%$ from networks. In Middle East, $28 \%$ of countries had no monitoring information, $44 \%$ was from campaigns, and $28 \%$ was from networks, with none from one station. In South America, $31 \%$ of countries have no monitoring information and $69 \%$ had information from networks, with none from campaigns or one station.

Interpretation Information about air pollution concentrations is scarce in low-income countries. Air quality is unlikely to improve in countries where data are scarce. These data are paramount to manage air pollution and to estimate the risks to which populations are exposed.

Funding São Paulo Research Foundation.

Contributors

LF and PS designed the study. LF and MVeras collected data. LF, MV, and LVB analysed data. LF, MV, LVB, and PS interpreted data. LF, LVB, and PS wrote the abstract.

Declaration of interests

We declare no competing interests. 
4.3. Estudo a partir de revisão sistemática e metanálise

Conduzi uma revisão sistemática e metánalise sobre os efeitos de curto prazo do material particulado e construí a narrativa a partir da América Latina. Os resultados para $\mathrm{o} \mathrm{MP}_{2.5}{ }^{*}$ já foram finalizados e estão em processo de submissão (vide manuscrito a seguir). A coordenação do Capítulo Latino Americano da Sociedade Internacional de Epidemiologia Ambiental se interessou pelo estudo e solicitou-me que eu o apresentasse na reunião do capítulo que ocorrerá este ano (2016) durante a conferência anual da sociedade.

\footnotetext{
* $\mathrm{MP}_{2.5}$ refere-se ao material particulado com diâmetro menor que 2.5 micrometros
} 
Artigo em processo de submissão.

O material suplementar referente a este artigo está apresentado na seção de Anexos (Anexo B).

Short-term effects of $\mathbf{P M}_{2.5}$ on daily health events in Latin America: a systematic review and meta-analysis.

Laís Fajersztajn ${ }^{1,2}$, Paulo Saldiva ${ }^{1,2}$, Luiz Alberto Amador Pereira ${ }^{3}$, Victor Figueiredo Leite $^{4}$, Anna Maria Buehler ${ }^{5}$

${ }^{1}$ Laboratory of Experimental Air Pollution (LIM05), Department of Pathology, School of Medicine, University of São Paulo, São Paulo, SP, Brazil; ${ }^{2}$ Institute for Advanced Studies of the University of São Paulo-IEA, São Paulo, SP, Brazil; ${ }^{3}$ Collective Health Pos-Graduation Program, Catholic University of Santos, Santos, SP, Brazil; ${ }^{4}$ Institute of Physical Medicine \& Rehabilitation, University of São Paulo, São Paulo, SP, Brazil; ${ }^{5}$ Health Technology Assessment Unit, Institute of Health Education and Science, German Hospital Oswaldo Cruz, São Paulo, SP, Brazil.

Acknowledgments: we thank the librarian assistants Mabel Fernandes Figueiredo and Rosa Fischi for assisting with the search strategy and retrieving references. We did not receive specific financial support to conduct this systematic review.

\footnotetext{
Abstract

Background: Short-term exposure to $\mathrm{PM}_{2.5}$ is consistent associated with increased risk for morbidity and mortality, but evidence for Latin American population is scarce.

Objective: Summarize the effect of short-term exposure to $\mathrm{PM}_{2.5}$ on morbidity and mortality in Latin American and evaluate evidence coverage and quality in the continent, using systematic review and meta-analysis.
} 
Data sources and extraction: The comprehensive search (six online databases and the reference lists of relevant studies) identified time-series or case-cross over studies investigating the sort-term associations between $\mathrm{PM}_{2.5}$ and daily health events (mortality, hospitalizations and emergency room visits for all-natural, cardiovascular or respiratory causes) in Latin America. Two reviewers independently accessed the internal validity of the studies and used random-effect models in the meta-analysis.

Data synthesis: We retrieved 1628 studies and elected nine (seven for the quantitative analyses). Each $10 \mu \mathrm{g} / \mathrm{m}^{3}$ increments in daily $\mathrm{PM}_{2.5}$ concentrations was significant associated with increased risk for respiratory and cardiovascular mortality in all-ages (polled $\mathrm{RR}=1.02,95 \% \mathrm{CI}, 1.02-1.02$ and $\mathrm{RR}=1.01,95 \% \mathrm{CI}, 1.01-1.02$, respectively). Risks for total mortality in all-ages and elderly, and respiratory hospitalization in children were not significant. Evidence was concentrated in six cities and 33\% presented high risk of bias. None of the studies investigated emergency room visits.

Conclusion: Short-term exposure to $\mathrm{PM}_{2.5}$ in Latin America is significant associated with increased risk for respiratory and cardiovascular mortality. Evidence is scarce, concentrated in few cities and some presented high risk of bias. Internal validity of epidemiological time-series studies on Environmental Health needs further investigation.

\section{Introduction}

Epidemiological evidence of the effects of fine particulate matter [PM with aerodynamic diameter $\left.\leq 2.5 \mu \mathrm{m}\left(\mathrm{PM}_{2.5}\right)\right]$ on morbidity and mortality is consistent, particularly on cardiovascular and respiratory systems (Anderson et al. 2004; Pope et a. 2006). Biological evidence supporting plausible mechanisms is clear and includes pulmonary oxidative stress, inflammation and altered cardiac autonomic function (Pope 
et al. 2006). However, evidence in Latin American is scarce and Systematic Reviews and Meta-analysis (SRMA) on the effects of $\mathrm{PM}_{2.5}$ on daily health events rarely pool evidence from Latin America (Adar et al. 2014; Shah et al. 2015). The World Health Organization (WHO) is updating current ambient Air Quality Guidelines, which stablishes standards for pollutants at concentrations considered sufficiently safe for human health (World Health Organization 2015). Transferability of existing concentration response functions (CRF) developed for European and North American cities to other countries with significant differences in air pollution levels are been questioned. According to the experts consulted by WHO, re-evaluation of the existing CRFs for $\mathrm{PM}_{2.5}$ is necessary, given the observed changes in the risk at extreme concentrations (World Health Organization 2015). Experts also underscored that current evidence show association of short-term $\mathrm{PM}_{2.5}$ exposure with mortality at levels below the current guideline, among other new evidence that need to be evaluated (World Health Organization 2015).

When the WHO air quality guidelines were last updated in 2005 (World Health Organization 2006), monitoring systems were scarce in cities from developing nations, including Latin American cities. Most of the data available in developing regions were exclusively for total suspended particles (TSP) concentrations, an overcome measure of particulate air pollution that includes particulates of bigger size. After a decade, evidence in Latin America remains delayed compared to North America and Europe. While developed countries are concerned with the health effects of fine $\left(\mathrm{PM}_{2.5}\right)$, ultrafine and coarse [PM with aerodynamic diameter 10-2.5 $\left.\left(\mathrm{PM}_{10-2.5}\right)\right]$ particles, few cities in Latin America depict evidence for these pollutants. Only eight Latin American countries have set National Air Quality Standards for $\mathrm{PM}_{2.5}$ (Green and Sánchez 2012), 
all above the final target of $25 \mu \mathrm{g} / \mathrm{m}^{3}$ for 24-hour average, current suggested by WHO (World Health Organization 2006). In 2012, the ESCALA multi-city study has established methodologic foundation for future research in Latin America and provided high quality evidence from nine cities to support air pollution control policies in the region (Romieu et al. 2012). However, the evidence was limited to the effects of $\mathrm{PM}_{10}$ on mortality.

Given the very high levels of $\mathrm{PM}_{2.5}$ pollution in Africa, Asia and Middle East (Brauer et al. 2012), air pollution in Latin America receives less attention in global analysis. However, between 1990 and 2013, $\mathrm{PM}_{2.5}$ annual mean levels trends increased in parts of South America and decreased in parts of Southeast Asia (Brauer et al. 2012).

In this systematic review, we aimed to summarize the evidence of the short-term effects of $\mathrm{PM}_{2.5}$ on daily health events in Latin America populations. We also aimed to identify the Latin American cities covered with local evidence on short-term health effects of $\mathrm{PM}_{2.5}$ and to evaluate the quality of the evidence identified.

\section{Methods}

This study followed a protocol previously registered at PROSPERO (registration CRD42015029673) and is reported according to both: PRISMA Statement recommendations for transparent reporting of systematic reviews (Moher et al. 2009) and MOOSE Guidelines for Meta-Analyses and Systematic Reviews of Observational Studies (Stroup 2000).

\section{Search strategy and eligibility criteria}

We searched six online databases (PubMed, Embase, Scopus, Web of Science, Cochrane and Lilacs) up to September 2015 to identify studies conducted in Latin America that analysed the associations of short-term exposure to $\mathrm{PM}_{2.5}$ with daily health 
events (mortality, hospital admission and emergency room visits). Search combined terms for exposure (e.g. "air pollution", or "particulate matter”), outcome (e.g. "hospital admission") and population (e.g. "Latin America" or name of countries). Controlled vocabulary of databases was included in the search string. We did not impose language or date restrictions to the search. We searched the reference lists of relevant reviews and studies for additional manuscripts and used Mendeley software for uploading the references. For detailed search strategy, see the Supplemental Material, S1.

Eligibility criteria included:

a) Original published time-series or case-cross over studies with a minimum period evaluated of one uninterrupted year, conducted in Latin American,

c) Studies that reported quantitative measurements of daily short-term exposure (up to a lag of seven days) to ambient $\mathrm{PM}_{2.5}$,

d) Studies that reported daily emergency room visits, hospital admissions, and/or mortality for all natural causes and/or all or selected respiratory causes and or all or cardiovascular causes. Related International Code of Disease (ICD $9^{\text {th }}$ and $10^{\text {th }}$ revision) for the causes included were: ICD-9 001-799, ICD-10 A00-T98 and Z00-Z99 (all natural causes), ICD-9 460-519, ICD-10 J00-J99 (respiratory causes) and, ICD-9 390459, ICD-10 I00-I99 (cardiovascular cases).

e) Studies that calculated or provided enough information to estimate the relative risk of the daily health event associated with an increment of $10 \mu \mathrm{g} / \mathrm{m}^{3}$ in $\mathrm{PM}_{2.5}$ levels.

f) Studies that reported the risk exclusively by subgroups other than age, daily event or diseases groups of interest for this review (e.g. by season or chemical composition of the particle) were excluded.

Study selection 
First, two independent reviewers screened all abstracts and titles for studies that potentially met the inclusion criteria. Then, reviewers evaluated full studies for final inclusion in the SR (Systematic Review) and recorded reasons for exclusion (see the Supplemental Material, Part2). Similar to reviews on global (Atkinson et al. 2014) and European evidence (Anderson et al. 2004), we selected only one study by setting to avoid overlapping of populations (see protocol at PROSPERO, registration CRD42015029673). We solved disagreements between reviewers by consensus along the stages.

\section{Data collection process and items}

Data items included citation information (e.g. year of publication) and characteristics of the location (eg. main air pollution sources), population (e.g. age), exposure (e.g. $\mathrm{PM}_{2.5}$ levels) and outcomes (e.g. total number of events) (See Table 1). We also collected information necessary to conduct meta-analysis of the relative risks related with $10 \mu \mathrm{g} / \mathrm{m}^{3}$ increments in $\mathrm{PM}_{2.5}$ levels (e.g. association measurements and its $95 \%$ Confidence Interval (CI)) and methodological characteristics necessary to assess the quality of the included studies (see Table 2). One reviewer extracted the data into Microsoft Excel 2013 and a second reviewer confirmed the information. Disagreements were solved by discussion.

\section{Risk of bias in individual studies}

Since there is no specific tool to evaluate methodological quality of time-series and case cross-over studies, two independently reviewers conducted a qualitative assessment, which classified studies as high or low risk of bias, according to criteria previously registered at the protocol of this study. We also verified funding sources and the conflicts of interest reported, which are recently being considered potential source of 
bias (Lam et al. 2014).

Summary measures

We calculated summary effects associated with $\mathrm{PM}_{2.5}$ levels in the statistical software RevMan 5.1 by daily event type (emergency room visits, hospital admissions and mortality), cause (total non-external causes, respiratory and cardiovascular causes) and age group (all-ages, elderly and children), if at least two association measurements were available from two different studies. Given that we calculated a polled effect for an entire continent, variations regarding population, outcomes and exposure characteristics among the cities included in the quantitative analysis were expected. For this reason, we used random effects model to estimate the summary measures and present them as Relative Risk (RR) with a 95\% Confidence Interval (95\% CI) for each increment of $10 \mu \mathrm{g} / \mathrm{m}^{3}$ in $\mathrm{PM}_{2.5}$ 24-hour average levels.

The lag (number of days between the exposure and the health event) reported by studies varied greatly and it was not possible to group the studies by lag structure. The lag used to calculate the summary measure was the lag reported. We chose the lag with the highest effect, if more than one lag was reported.

We used Cochrane $\mathrm{Q}$ test (significance level: 0.1 ) and $\mathrm{I}^{2}$ statistic to test statistical heterogeneity. $\mathrm{I}^{2}$ statistic quantifies heterogeneity by calculating the proportion of variation occurred by heterogeneity rather than by chance (Higgins et al. 2003). For $\mathrm{I}^{2}$, we considered that values ranging from 0 to 30,30 to 50 and $>50$ indicated low, moderate and high heterogeneity, respectively. We also reduced potential heterogeneity due to populations and outcome cause differences by polling evidence grouped by cause/age pairs. We planned to performed sub-groups analysis by pollutant model (single vs multi-pollutant), pollution source (rural vs urban) and risk of bias between 
studies (combining low risk of bias studies only), if heterogeneity was statistically significant. Non-quantitative data was presented descriptively.

Publication bias assessment

If 10 or more studies are included in the review we accessed publication bias through funnel plot and Egger test (Egger et al. 1997).

\section{Results}

Study selection

Search retrieved 1628 studies, nine were elected for the qualitative analysis and seven for the quantitative analyses (Figure 1). Elected studies were conducted in three countries (Chile, Brazil and Mexico), distributed in six cities, mostly with less than a million inhabitants. None of the studies investigated the effects of $\mathrm{PM}_{2.5}$ on emergency room visits.

Automotive was the main source of air pollution reported, followed by biomass burning and industrial sources. $\mathrm{PM}_{2.5}$ daily mean varied from 7.5 to $81.0 \mu \mathrm{g} / \mathrm{m}^{3}$ among the included studies (Table 1).

The most studied decade was the 2000's (44\%), followed by the 1990's (35\%), 2010's (23\%) and 1980's (5\%). All elected studies were time-series studies published as articles. Only one was a multi-city study (evaluated the metropolitan area). Elected studies were mostly published in English (89\%), and 56\% of the included studies used single-pollutant models exclusively (see Supplemental Material, TableS1).

The quality assessment revealed that $33 \%$ of the included studies presented high risk of bias, $43 \%$ if we consider only studies elected for the quantitative analysis. Frailties in statistical adjustments (e.g. not using the Akaike criteria), in exposure characterization (not using monitoring networks) and controlling for confounders (not controlling for 
short trends such as for day of the week) were the main reasons why studies were classified as high risk of bias. When reported, conflict of interest was absent and financial sources were related to governmental agencies and University-related grants (Table 2).

Measurements combined for meta-analysis were derived from single-pollutant models, except for total mortality in elderly, where evidence was available for single and multipollutant models. All meta-analysis combined evidence from two different studies, except from hospital admissions where evidence from three were combined. Given the low number of studies combined and their characteristics, we did not perform subgroup analysis by pollution source (rural vs urban) and risk of bias (low vs high risk of bias).

\section{Mortality}

Meta-analysis of the risks for respiratory mortality in all-ages associated with $\mathrm{PM}_{2.5}$ levels showed a significant $2 \%$ increased risk (RR per $10 \mu \mathrm{g} / \mathrm{m}^{3}=1.02,95 \%$ CI, 1.02 $1.02 ; \mathrm{I}^{2}=0 \%$ ) (Figure 2). Meta-analysis of the risk for cardiovascular mortality associated with $\mathrm{PM}_{2.5}$ levels showed a significant $1 \%$ increased risk (RR per $10 \mu \mathrm{g} / \mathrm{m}^{3}=$ $1.01,95 \%$ CI, 1.01-1.02; $\mathrm{I}^{2}=0 \%$ ) (Figure 2). One of the studies combined presented high risk of bias.

Risk for total mortality was not significant neither for all-ages (RR per $10 \mu \mathrm{g} / \mathrm{m}^{3}=1.01$, $95 \% \mathrm{CI}, 1.00-1.01 ; \mathrm{I}^{2}=0 \%$ ) (Figure 2 ), nor for elderly $\left(\mathrm{RR}\right.$ per $10 \mu \mathrm{g} / \mathrm{m}^{3}=1.01,95 \% \mathrm{CI}$, $1.00-1.02 ; \mathrm{I}^{2}=55 \%$ ) The risk for total mortality in elderly remained not significant when we combined measures based on multi-pollutant models, all adjusted for $\mathrm{O}_{3}$ : $\mathrm{RR}$ per $10 \mu \mathrm{g} / \mathrm{m}^{3}=1.01,95 \%$ CI, 0.99-1.03; $\mathrm{I}^{2}=73 \%$ (see Supplemental Material, Figure S1). All studies combined presented low risk of bias.

For hospital admissions, meta-analysis showed no statistical association between $\mathrm{PM}_{2.5}$ 
levels and daily hospital admissions and presented significant high heterogeneity: RR per $10 \mu \mathrm{g} / \mathrm{m}^{3}=1.03,95 \% \mathrm{CI}, 0.99-1.08 ; \mathrm{I}^{2}=68 \%$ ) (Figure 3 ). The studies combined used satellite-derived measurements and two depicted high risk of bias.

\section{Discussion}

Our results showed significant associations between short-term exposure to $\mathrm{PM}_{2.5}$ in Latin America and increased risk for respiratory and cardiovascular mortality in allages. The risks for each $10 \mu \mathrm{g} / \mathrm{m}^{3}$ increment in $\mathrm{PM}_{2.5}$ levels ranged between 1 and $2 \%$ and heterogeneity between studies was low. On the other hand, risks associated with short-term exposure to $\mathrm{PM}_{2.5}$ for total mortality in all-ages and in elderly and respiratory hospitalization in children were not significant. Imprecision might explain why some meta-analysis were not statistically significant in our review, since CIs of the combined studies tended to be larger in the non-significant meta-analysis (particularly for hospitalizations meta-analysis), compared to significant meta-analysis (respiratory and cardiovascular mortality). Frequently, multi-city studies find larger effects when the analysis is restricted to elderly populations (Romieu et al. 2012), because elderly are more vulnerable to air pollution adverse health effects. However our meta-analysis for total mortality in elderly was not significant. Because populations are exposed to a complex mixture of air pollutants, not single pollutants, researchers (and policy makers) have being encouraged to move towards a multi-pollutant approach to air quality, rather than singlepollutant models (Dominici et al. 2012). In our review, most of the risks reported were based on single pollutant models. Meta-analysis for multi-pollutant models (adjusted for $\mathrm{O}_{3}$ ) were just feasible for total mortality in elderly, but the related risks were not significant in both pollutant models

Our results are partially in accordance with other meta-analysis on the short-term association of $\mathrm{PM}_{2.5}$ and daily health events in the world (Adar et al. 2014; Atkinson et 
al. 2014), pointing out that, while local evidence is scarce, extrapolating evidence from other regions to control particulate pollution in Latin America might be reasonable.

Compared to the present review, Atkinson et al. (2014) study identified fewer Latin American studies and did not evaluated all the outcomes considered in this review for Latin American region, possible due to differences in the search strategy adopted. We searched Lilacs, a specific database for scientific literature of Latin American, and other databases up to September 2015, while Atkinson's review searched global databases exclusively up to May 2011. While our results are mostly in accordance with Atkinson's global findings, our results contrast with Atkinson's findings for Latin America for total, respiratory and cardiovascular mortality in all-ages. Both reviews combined evidence from two studies to perform meta-analysis, but in our review CIs of the included studies were more precise.

Evidence on the short-term effects of $\mathrm{PM}_{2.5}$ in daily health events conducted in Latin America is scarce, concentrated in few locations and publication trend is not increasing. The scarcity of studies in the continent might be reflecting lack of exposure data, since only half of Latin American cities with monitoring stations for $\mathrm{PM}_{10}$, also monitors $\mathrm{PM}_{2.5}$ (Green and Sánchez 2012). Moreover, in some cities, $\mathrm{PM}_{2.5}$ measurements started in recent years and occur in a few percentage of the existing monitoring stations (MMA 2014). In our review, all Brazilians studies included estimated population exposure through satellite estimations. Sophisticated satellite-based estimates are a promising tool to overcome the scarcity of exposure data, given that correlation with ground-level $\mathrm{PM}_{2.5}$ mass might reach $81 \%$ (Van Donkelaar et al. 2016) and The Global Burden of Disease Study is already using satellite based $\mathrm{PM}_{2.5}$ estimates (Brauer et al. 2012).

One of the strengths of our review was to evaluate the internal validity of the included 
studies, which is not frequent in most SRMAs of epidemiological time-series studies, since, to our knowledge, no validated tool evaluates methodological quality of timeseries. Despite advances in methodology of SRMAs involving epidemiological observational studies in general (Stroup 2000) and of epidemiological studies of environmental health (EH) in particular (Sheehan and Lam 2015), it is still difficult to adapt the recommendations to assess the risk of bias in time-series studies. Cochrane Collaboration recommend tools for randomized controlled trials and non-randomized studies of intervention (Higgins and Green 2011), both not applicable to time-series design. Yet, time-series studies have being playing a relevant role in air pollution regulatory process, because they estimate the burden of disease attributable to air pollution exposure and the related CRF can be used in cost-benefit analysis (Bell et al. 2004). Time-series studies use regression models to assess the effects of short-term changes in $\mathrm{PM}_{2.5}$ levels on acute health effects by estimating associations between dayto-day variations in both air pollution and in mortality and morbidity counts. The study design uses aggregated level data for exposure and outcome. Confounding bias arise from factors that vary in short time scales and may be associated with particulate and health (e.g. temperature). Statistical specificities (e.g. accounting for serial correlation in the residuals) also play a role (Bell et al. 2004).

Our quality assessment followed an a priori criteria and two reviewers independently assessed key methodologically potential sources of bias in human epidemiological observational studies in $\mathrm{EH}$ in general (e.g. exposure characterization and controlling for confounders) (Sheehan and Lam 2015) and of time-series design in particular (e.g. statistical adjustments) (Bell et al. 2004). Frailties in at least one of the potential source of bias domains were frequent; underlining that internal validity of time-series study 
design on EH SRMAs needs further investigations.

Since we retrieved less than 10 studies for each health endpoints (outcome/cause/age), we did not evaluate publication bias, a limitation of this review.

Multi-city studies standardize statistical approach and therefore minimize potential risk of bias due differences in statistical methodology of time-series studies (Bell et al., 2004). To the extent that time-series design usually uses secondary dada relatively accessible from public sources, efforts to conduct high quality multi-city studies might be preferable than conducting meta-analysis based on individual studies data retrieved in a SR. However, $\mathrm{PM}_{2.5}$ monitoring stations are scarce in Latin America (Green and Sánchez 2012) and the multi-city study for Latin America region (Romieu et al. 2012) did not evaluate the effects of $\mathrm{PM}_{2.5}$ on health, making this review relevant.

\section{Conclusion}

Evidence in Latin America is scarce, concentrated and trend of publication is not increasing. Short-term exposure to $\mathrm{PM}_{2.5}$ in the continent is significant associated with increased risk for respiratory and cardiovascular mortality in all-ages in region. Our results are in accordance with evidence from other parts of the world, pointing out that, while local evidence is scarce, extrapolating evidence from other regions to control particulate pollution in Latin America might be reasonable. Quality assessment identified frailties in key methodological sources of bias in observational studies in EH in general (exposure characterization and controlling for confounders) and in time-series design in particular (statistical adjustments), thus assessing the internal validity of timeseries study design in SRMA on EH needs further investigations.

\section{References}

Adar SD, Filigrana PA, Clements N, Peel JL. 2014. Ambient Coarse Particulate Matter 
and Human Health: A Systematic Review and Meta-Analysis. Curr. Environ. Heal. reports 1:258-274; doi:10.1007/s40572-014-0022-z.

Anderson H, Atkinson R, Peacock J, Marston L, Konstantinou K. 2004. Meta-analysis of time-series studies and panel studies of particulate matter (PM) and ozone (O3). Rep. a WHO Task Gr. 1-68.

Atkinson RW, Kang S, Anderson HR, Mills IC, Walton HA. 2014. Epidemiological time series studies of PM2.5 and daily mortality and hospital admissions: a systematic review and meta-analysis. Thorax 69:660-5; doi:10.1136/thoraxjnl2013-204492.

Bell ML, Samet JM, Dominici F. 2004. Time-series studies of particulate matter. Annu. Rev. Public Health

25:247-280; doi:10.1146/annurev.publhealth.25.102802.124329.

Borja-Aburto VH, Castillejos M, Gold DR, Bierzwinski S, Loomis D. 1998. Mortality and ambient fine particles in southwest Mexico City, 1993-1995. Environ. Health Perspect. 106: 849-855.

Brauer M, Amann M, Burnett RT, Cohen A, Dentener F, Ezzati M, et al. 2012. Exposure Assessment for Estimation of the Global Burden of Disease Attributable to Outdoor Air Pollution. Environ. Sci. Technol. 46:652-660; doi:10.1021/es2025752.

Castillejos M, Borja-Aburto VH, Dockery DW, Gold DR, Loomis D. 2000. Airborne coarse particles and mortality. Inhal. Toxicol. 12: 61-72.

Cesar ACG, Nascimento LFC, De Carvalho JA, Gobbo Cesar AC, Nascimento LFC, de Carvalho Jr. JA. 2013. Association between exposure to particulate matter and hospital admissions for respiratory diseases in children. Rev. Saude Publica 47:1209-1212; doi:10.1590/S0034-8910.2013047004713.

Dales RE, Cakmak S, Vidal CB. 2010. Air pollution and hospitalization for venous thromboembolic disease in Chile. J. Thromb. Haemost. 8:669-674; doi:10.1111/j.1538-7836.2010.03760.x.

Dominici F, Peng RD, Barr CD, Bell ML. 2012. Single-Pollutant to a Multi-pollutant Approach. 21:187-194; doi:10.1097/EDE.0b013e3181cc86e8.Protecting.

Egger M, Davey Smith G, Schneider M, Minder C. 1997. Bias in meta-analysis detected by a simple, graphical test. BMJ 315:629-34; doi:10.1136/bmj.316.7129.469.

Green J, Sánchez S. 2012. Air Quality in Latin America: An Overview. Clean air Inst. 1-28; doi:10.1017/CBO9781107415324.004.

Higgins J, Green S. 2011. Cochrane Handbook for Systematic Reviews of Interventions Version 5.1.0 [updated March 2011]. The Cochrane Collaboration.

Higgins JPT, Thompson SG, Deeks JJ, Altman DG. 2003. Measuring inconsistency in meta-analyses. BMJ Br. Med. J. 327:557-560; doi:10.1136/bmj.327.7414.557.

Ignotti E, Hacon SS, Junger WL, Mourão D, Longo K, FreitasS, et a. 2010. Air pollution and hospital admissions for respiratory diseases in the subequatorial Amazon: a time series approach. Cad. Saúde Pública. 26(4):747-761; doi: doi.org/10.1590/S0102-311X2010000400017.

Lam J, Koustas E, Sutton P, Johnson PI, Atchley DS, Sen S, et al. 2014. The Navigation Guide - evidence-based medicine meets environmental health: integration of animal and human evidence for PFOA effects on fetal growth. Environ. Health Perspect. 122:1040-51; doi:10.1289/ehp.1307923.

Loomis D, Castillejos M, Gold DR, McDonnell W, Borja-Aburto VH. 1999. Air pollution and infant mortality in Mexico City. Epidemiology 10:118-123; doi:10.1097/00001648-199903000-00006. 
MMA. 2014. $1^{\circ}$ diagnóstico da rede de monitoramento da qualidade do ar no Brasil. 267.

Moher D, Liberati A, Tetzlaff J, Altman DG, Grp P. 2009. Preferred Reporting Items for Systematic Reviews and Meta-Analyses: The PRISMA Statement (Reprinted from Annals of Internal Medicine). Phys. Ther. 89:873-880; doi:10.1371/journal.pmed.1000097.

Pope CA, Dockery DW, Chow JC, Watson JG, Mauderly JL, Costa DL, et al. 2006. Health Effects of Fine Particulate Air Pollution: Lines that Connect. J. Air Waste Manage. Assoc. 56:1368-1380; doi:10.1080/10473289.2006.10464545.

Reyna MA, Bravo ME, López R, Nieblas EC, Nava ML. 2012. Relative risk of death from exposure to air pollutants: A short-term (2003-2007) study in Mexicali, Baja California, México. Int. J. Environ. Health Res. 22:370-386; doi:10.1080/09603123.2011.650153.

Romieu I, Gouveia N, Cifuentes LA, de Leon AP, Junger W, Vera J, et al. 2012. Multicity study of air pollution and mortality in Latin America (the ESCALA study). Res. Rep. Health. Eff. Inst. 5-86.

Sanhueza PH, Vargas CR, Jiménez J.P. Dauly mortality in Santiago and its relation with air pollution. 1998. Rev Méd Chile 127:235-242.

Shah AS V, Lee KK, McAllister DA, Hunter A, Nair H, Whiteley W, et al. 2015. Short term exposure to air pollution and stroke: systematic review and meta-analysis. BMJ 350:h1295; doi:10.1136/bmj.h1295.

Sheehan MC, Lam J. 2015. Use of Systematic Review and Meta-Analysis in Environmental Health Epidemiology: a Systematic Review and Comparison with Guidelines. Curr. Environ. Heal. Reports 2:272-283; doi:10.1007/s40572-0150062-z.

Silva AM da, Mattos IE, Ignotti E, Hacon S de S. 2013. Particulate matter originating from biomass burning and respiratory. Rev. Saude Publica 47:345-352; doi:10.1590/S0034-8910.2013047004410.

Stroup DF. 2000. Meta-analysis of Observational Studies in Epidemiology $<$ SUBTITLE $>$ A Proposal for Reporting $</$ SUBTITLE $>$. Jama 283:2008; doi:10.1001/jama.283.15.2008.

Valdes A, Zanobetti A, Halonen JI, Cifuentes L, Morata D, Schwartz J. 2012. Elemental concentrations of ambient particles and cause specific mortality in Santiago, Chile: a time series study. Environ. Health 11:82; doi:10.1186/1476-069X-11-82.

Van Donkelaar A, Martin R V., Brauer M, Hsu NC, Kahn RA, Levy RC, et al. 2016. Global Estimates of Fine Particulate Matter using a Combined GeophysicalStatistical Method with Information from Satellites, Models, and Monitors. Environ. Sci. Technol. 50:3762-3772; doi:10.1021/acs.est.5b05833.

Vargas C.R JJPSPH. 1998. Daily mortality in Santiago and its relationship with air pollution. Rev. Med. Chil. 127: 235-242.

World Health Organization. 2006. WHO Air quality guidelines for particulate matter, ozone, nitrogen dioxide and sulfur dioxide: global update 2005: summary of risk assessment. Geneva World Heal. Organ. 1-22; doi:10.1016/0004-6981(88)901096.

World Health Organization. 2015. WHO Expert Consultation: Available evidence for the future update of the WHO Global Air Quality Guidelines (AQGs). 10. 
Table 1. Characteristics of the studies included in the systematic review

\begin{tabular}{|c|c|c|c|c|c|c|c|c|c|c|}
\hline Reference & Study period & City (Country) & $\begin{array}{l}\text { Air pollution } \\
\text { sources }\end{array}$ & $\begin{array}{l}\text { Inhabitants } \\
\text { reported }\end{array}$ & $\begin{array}{l}\mathrm{PM}_{2.5} \text { mean }(\mathrm{SD}) \text { in } \\
\mu \mathrm{g} / \mathrm{m}^{3}\end{array}$ & $\begin{array}{l}\text { Population } \\
\text { in years }\end{array}$ & $\begin{array}{l}\text { Outcome } \\
\text { (cause) }\end{array}$ & $\begin{array}{l}\text { Number of } \\
\text { events }\end{array}$ & $\begin{array}{l}\text { Pollutant } \\
\text { model }\end{array}$ & $\begin{array}{l}\text { Risk of } \\
\text { bias }\end{array}$ \\
\hline $\begin{array}{l}\text { Dales et al. } \\
2010^{\ddagger}\end{array}$ & $1998-2005$ & $\begin{array}{l}\text { Santiago } \\
\text { metropolitan region } \\
\text { (Chile) }\end{array}$ & NI & 5.370 .000 & $32.9(20.2)$ & All-ages & $\mathrm{HA}\left(\mathrm{CV}^{0}\right)$ & 282.645 & both & low \\
\hline $\begin{array}{l}\text { Cesar et al. } \\
2013\end{array}$ & $2011-2012$ & Piracicaba (Brazil) & $\begin{array}{l}\text { biomass, } \\
\text { automotive }\end{array}$ & 350.000 & $26.8(16.7)$ & $<10$ & $\mathrm{HA}(\mathrm{R})$ & 437 & single & high \\
\hline $\begin{array}{l}\text { Ignotti et al. } \\
2010\end{array}$ & $2000-2004$ & $\begin{array}{ll}\text { Alta } & \text { Floresta } \\
\text { (Brazil) } & \end{array}$ & biomass & 101.278 & $20.4(32.6)$ & $<5$ & $\mathrm{HA}(\mathrm{R})$ & 481 & single & high \\
\hline $\begin{array}{l}\text { Silva et al. } \\
2013\end{array}$ & 2005 & Cuiabá (Brazil) & biomass & 550.562 & $7.5(10.4)$ & $<5$ & $\mathrm{HA}(\mathrm{R})$ & 1.152 & single & low \\
\hline $\begin{array}{l}\text { Loomis et } \\
\text { al. } 2009^{*}\end{array}$ & $1993-1995$ & $\begin{array}{l}\text { Ciudad de México } \\
\text { (Mexico) }\end{array}$ & $\begin{array}{l}\text { automotive, } \\
\text { industrial }\end{array}$ & 2.500 .000 & $27.4(10.5)$ & $<1$ & $\mathrm{M}(\mathrm{A})$ & 2.798 & both & low \\
\hline $\begin{array}{l}\text { Borja- } \\
\text { Aburto et al. } \\
1998\end{array}$ & $1993-1995$ & $\begin{array}{l}\text { Ciudad de México } \\
\text { (Mexico) }\end{array}$ & $\begin{array}{l}\text { automotive, } \\
\text { industrial }\end{array}$ & 2.500 .000 & $27.0(11.0)$ & $\begin{array}{l}\text { All-ages, } \\
>65\end{array}$ & $\mathrm{M}(\mathrm{A}, \mathrm{R}, \mathrm{CV})$ & 1.152 & both & low \\
\hline $\begin{array}{l}\text { Sanhueza, et } \\
\text { a. } 1998\end{array}$ & $1988-1993$ & Santiago (Chile) & NI & NI & $81.0(\mathrm{NI})$ & $\begin{array}{l}\text { All-ages, } \\
>65\end{array}$ & $\mathrm{M}(\mathrm{A})$ & $\begin{array}{l}76.442 \\
(A,>65)\end{array}$ & both & low \\
\hline $\begin{array}{l}\text { Valdes et al. } \\
2012\end{array}$ & $1998-2007$ & Santiago (Chile) & NI & NI & 34.0 (NI) & All-ages & $\mathrm{M}(\mathrm{R}, \mathrm{CV})$ & 92.891 & single & high \\
\hline $\begin{array}{l}\text { Reyna et al. } \\
2012\end{array}$ & $2003-2007$ & Mexicali (Mexico) & $\begin{array}{l}\text { automotive, } \\
\text { unpaved roads }\end{array}$ & 856.000 & $60.6(32.3)$ & All-ages & $\mathrm{M}\left(\mathrm{A}^{*}\right)$ & 872.350 & single & low \\
\hline
\end{tabular}

Abbreviations: SD, standard deviation; NI, not informed; PM, particulate matter; M, mortality; HA, hospital admissions; E, emergency room visits; A, all non-extemal causes; CV, cardiovascular disease; $R$, respiratory disease; Single, single-pollutant model; Multi, multi-pollutant model; Both, single and multi-pollutant model. "Not all studies evaluated the whole population of the city investigated, therefore some inhabitants reported reflect the population of the area covered by the hospitals included in the analysis, not all the city. * Reyna et al. (2012) also evaluated respiratory mortality, but did not present the associations with short-term exposure to PM 2.5 for this outcome. -Study evaluated specific cardiovascular disease: I26 an I80 according to the Intemational Classification of Disease, 10 ${ }^{\text {th }}$ Revision (ICD-10). ${ }^{\text {tnot }}$ included in the quantitative analysis. Dales et al. (2010) was the only study that evaluated cardiovascular hospitalizations and Loomis et al. (1999) the only study that evaluated mortality in children. 
Table 2. Quality assessment of the included studies in the systematic review

\begin{tabular}{|c|c|c|c|c|c|c|c|c|c|c|c|c|c|c|}
\hline \multirow[b]{2}{*}{ Reference } & \multicolumn{2}{|c|}{ Selection } & \multicolumn{3}{|c|}{ Exposure } & \multicolumn{4}{|c|}{ Confounders } & \multicolumn{5}{|c|}{ Statistical adjustments of the model } \\
\hline & ICD & Source & Source ${ }^{\infty}$ & Network & Daily & $\begin{array}{l}\text { Long } \\
\text { trends }\end{array}$ & $\begin{array}{l}\text { Short } \\
\text { trends }\end{array}$ & Temp & Hum & Autocorrelation & Akaike & $\begin{array}{l}\text { Risk of } \\
\text { bias }\end{array}$ & Founding source & $\begin{array}{l}\text { Conflict of } \\
\text { interest }\end{array}$ \\
\hline Borja- & & & & & & & & & & & & & NI & NI \\
\hline $\begin{array}{l}\text { Arbuto et } \\
\text { al., } 1998\end{array}$ & $\mathrm{Y}$ & $\mathrm{Y}$ & $\mathrm{Y}$ & $\mathrm{N}$ & $\mathrm{Y}$ & $\mathrm{Y}$ & $\mathrm{N}$ & $\mathrm{Y}$ & $\mathrm{Y}$ & $\mathrm{Y}$ & $\mathrm{Y}$ & Low & & \\
\hline Loomis et & & & & & & & & & & & & & NI & No conflict \\
\hline al. 1999 : & $\mathrm{Y}$ & $\mathrm{Y}$ & $\mathrm{Y}$ & $\mathrm{N}$ & $\mathrm{Y}$ & $\mathrm{Y}$ & $\mathrm{N}$ & $\mathrm{Y}$ & $\mathrm{N}$ & $\mathrm{Y}$ & $\mathrm{Y}$ & Low & & \\
\hline $\begin{array}{l}\text { Cesar et al., } \\
2013\end{array}$ & $\mathrm{Y}$ & $\mathrm{Y}$ & $\mathrm{Y}$ & $\mathrm{N}^{*}$ & $\mathrm{Y}$ & $\mathrm{N}$ & $\mathrm{N}$ & $\mathrm{Y}$ & $\mathrm{N}$ & $\mathrm{N}$ & $\mathrm{N}$ & High & $\begin{array}{l}\text { Govemmental research } \\
\text { agency }\end{array}$ & No conflict \\
\hline Dales et al., & & & & & & & & & & & & & NI & No conflict \\
\hline $2010^{*}$ & $\mathrm{Y}$ & $\mathrm{Y}$ & $\mathrm{N}$ & $\mathrm{Y}$ & $\mathrm{Y}$ & $\mathrm{N}$ & $\mathrm{N}$ & $\mathrm{Y}$ & $\mathrm{Y}$ & $\mathrm{Y}$ & $\mathrm{Y}$ & Low & & \\
\hline $\begin{array}{l}\text { Ignotti et al., } \\
2010\end{array}$ & $\mathrm{Y}$ & $\mathrm{Y}$ & $\mathrm{Y}$ & $\mathrm{N}^{*}$ & $\mathrm{Y}$ & $\mathrm{N}$ & $\mathrm{N}$ & $\mathrm{Y}$ & $\mathrm{Y}$ & $\mathrm{N}$ & $\mathrm{N}$ & High & $\begin{array}{l}\text { Govemmental research } \\
\text { agencies }\end{array}$ & NI \\
\hline $\begin{array}{l}\text { Reyna et al., } \\
2012\end{array}$ & $\mathrm{Y}$ & $\mathrm{Y}$ & $\mathrm{Y}$ & $\mathrm{Y}$ & $\mathrm{Y}$ & $\mathrm{Y}$ & $\mathrm{Y}$ & $\mathrm{Y}$ & $\mathrm{Y}$ & $\mathrm{Y}$ & $\mathrm{N}$ & Low & University-related grants & NI \\
\hline $\begin{array}{l}\text { Sanhueza, et } \\
\text { a. } 1998\end{array}$ & $\mathrm{Y}$ & $\mathrm{Y}$ & $\mathrm{Y}$ & $\mathrm{Y}$ & $\mathrm{Y}$ & $\mathrm{Y}$ & $\mathrm{Y}$ & $\mathrm{Y}$ & $\mathrm{Y}$ & $\mathrm{Y}$ & $\mathrm{N}$ & Low & $\begin{array}{l}\text { Govemmental research } \\
\text { agency and University- } \\
\text { related grants }\end{array}$ & NI \\
\hline $\begin{array}{l}\text { Silva et al. } \\
2013\end{array}$ & $\mathrm{Y}$ & $\mathrm{Y}$ & $\mathrm{Y}$ & $\mathrm{N}^{*}$ & $\mathrm{Y}$ & $\mathrm{Y}$ & $\mathrm{Y}$ & $\mathrm{Y}$ & $\mathrm{Y}$ & $\mathrm{N}$ & $\mathrm{N}$ & Low & NI & No conflict \\
\hline $\begin{array}{l}\text { Valdes et } \\
\text { al., } 2012\end{array}$ & $\mathrm{Y}$ & $\mathrm{Y}$ & $\mathrm{Y}$ & $\mathrm{N}$ & $\mathrm{N}$ & $\mathrm{Y}$ & $\mathrm{Y}$ & $\mathrm{Y}$ & $\mathrm{Y}$ & $\mathrm{N}$ & $\mathrm{N}$ & High & NI & No conflict \\
\hline
\end{tabular}

Abbreviations: ICD, Intemational Code of Disease informed; Y, yes; N, no; U, unclear; NI, not informed; Network, monitoring network; Daily, Daily Measurements; Akaike,

Akaike criteria; Temp, temperature; Hum, humidity

† Studies included in the quantitative analysis. $\mathrm{N}^{*}$, satellite; ${ }^{\circ}$ Source of the outcome data; "Source of the exposure data; ${ }^{*}$ not included in the quantitative analysis. Dales et al.

(2010) was the only study that evaluated cardiovascular hospitalizations and Loomis et al. (1999) the only study that evaluated mortality in children. 
Figure 1. Study selection flow diagram
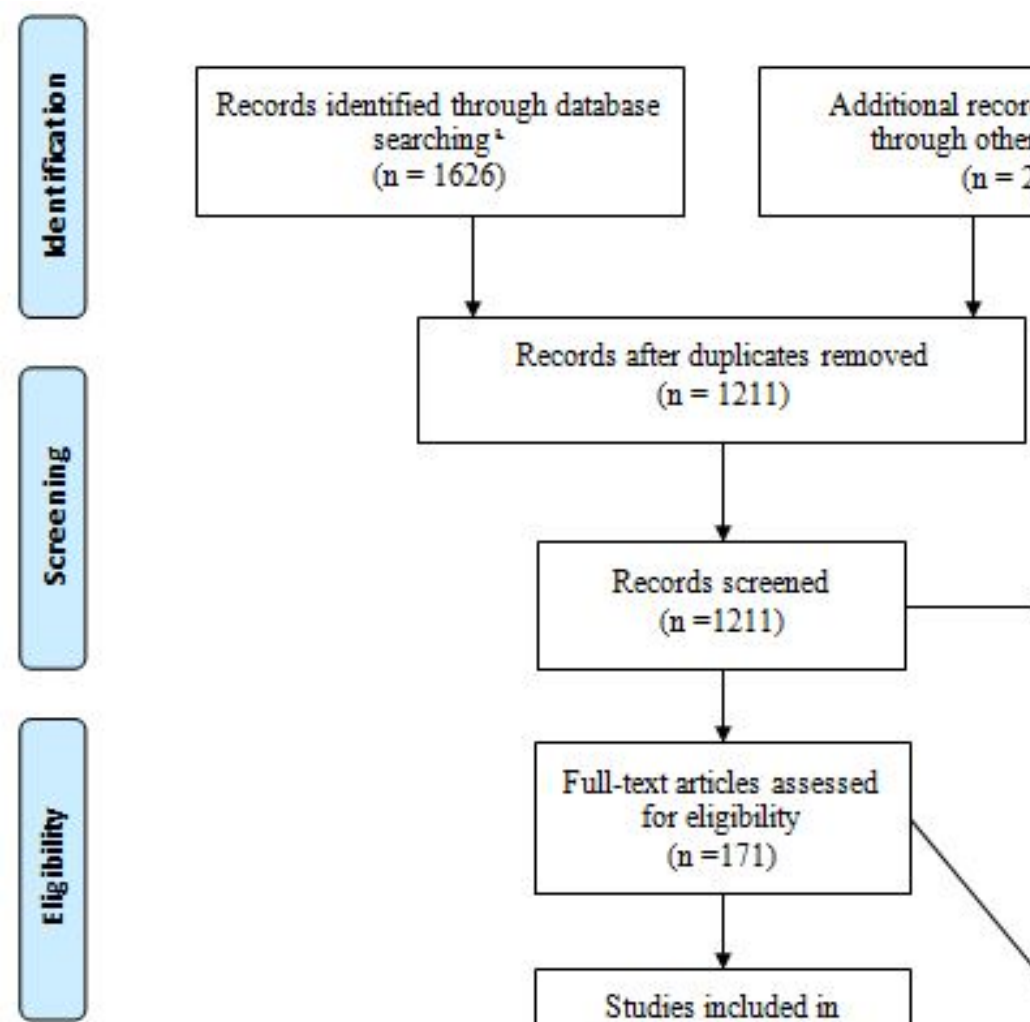

Additional records identified through other sources $(n=2)$
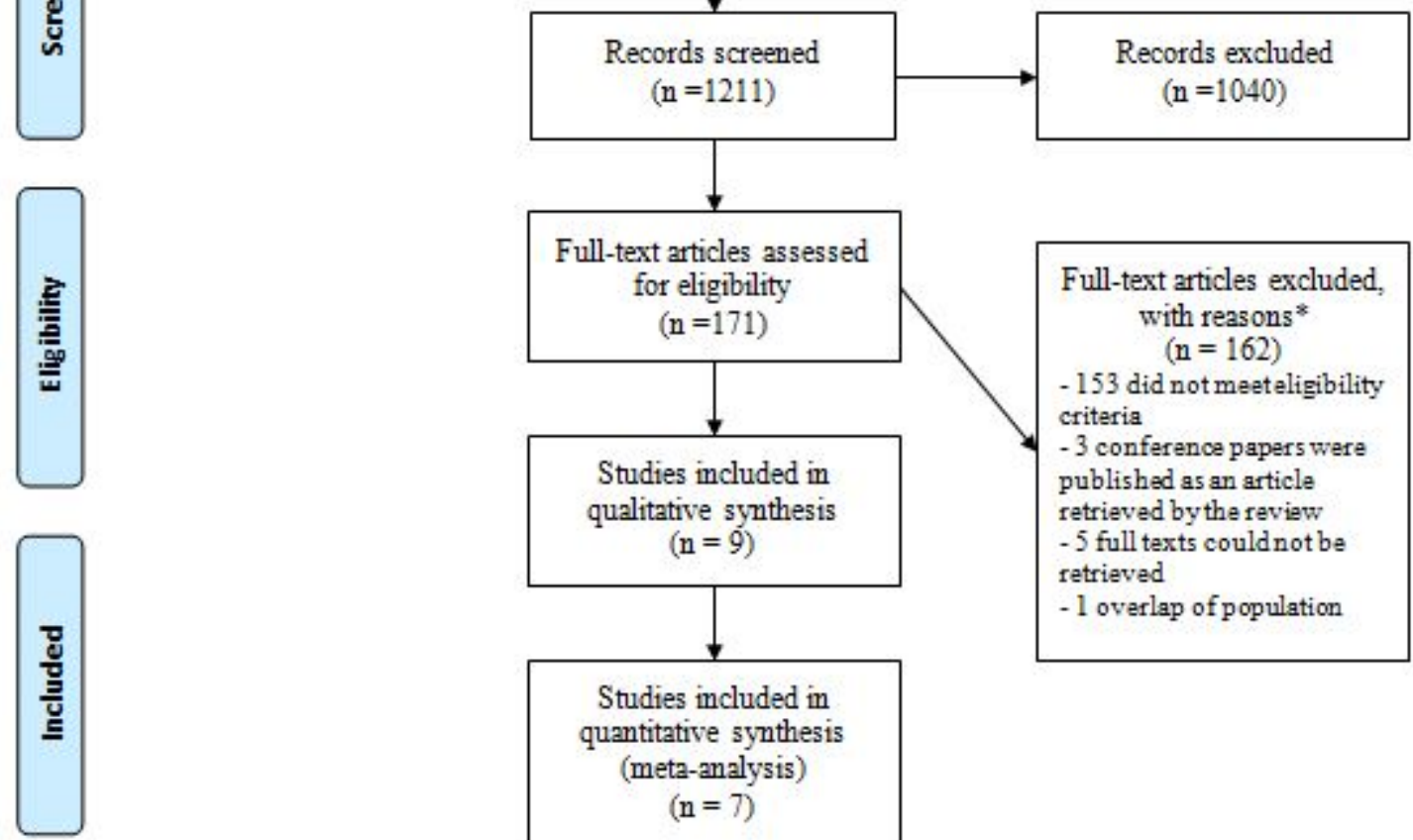

Studies included in quantitative synthesis (meta-analysis) $(n=7)$

* see the Supplemental Material, Part2 for the complete list of studies excluded by reason.

${ }^{ }$databases searched: PubMed, Embase, Scopus, Web of Science, Cochrane and Lilacs up to September 2015 
Figure 2. Forest plots for the risks for daily mortality by cause associated with shortterm exposure to $\mathrm{PM}_{2.5}$ levels.

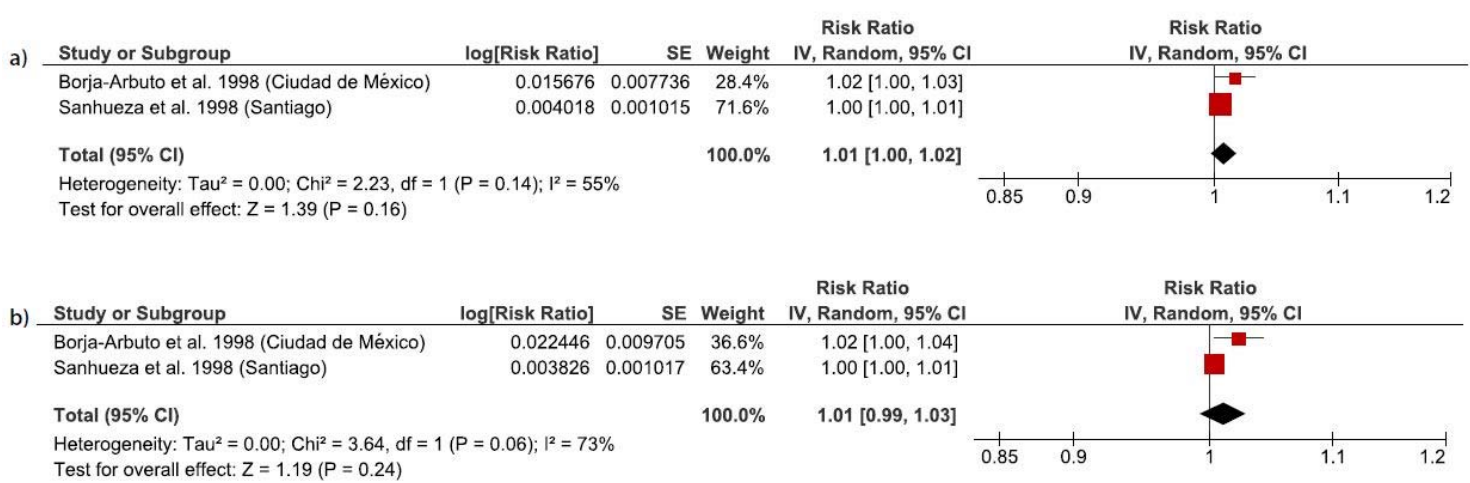

Risks are reported for increments of $10 \mu \mathrm{g} / \mathrm{m}^{3}$ in $\mathrm{PM}_{2.5}$ levels and were calculated for allages, based on single-pollutant models. (a) all-causes, (b) respiratory causes, and c) cardiovascular causes.

Figure 3. Forest plots for the risks for daily respiratory hospitalization in children associated with short-term exposure to $\mathrm{PM}_{2.5}$ levels by pollutant model.

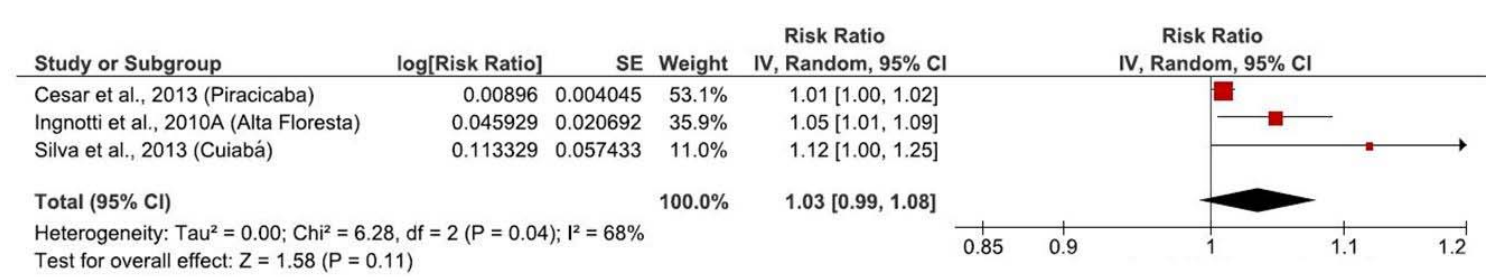

Risks are reported for increments of $10 \mu \mathrm{g} / \mathrm{m}^{3}$ in $\mathrm{PM}_{2.5}$ levels and were calculated based on single-pollutant models. 
4.4.Narrativas para públicos diversos

Nesta tipologia, incluo um trabalho sobre poluição do ar e três trabalhos sobre urbanização e qualidade de vida, entre artigos e capítulos de livros focados em públicos diversos. Ir além da poluição do ar e trabalhar com outros temas relativos à urbanização e qualidade de vida são um indicativo de que de fato consegui integrar diferentes áreas do conhecimento.

4.4.1. Capítulo de livro sobre poluição do ar e reprodução humana

Neste estudo ${ }^{(58)}$ contribui como coautora e auxiliei na construção da narrativa do tema, principalmente a partir da escolha e produção de uma imagem para a narrativa do capítulo. De modo similar as imagens selecionadas na tipologia 4.1. Estudos a partir da análise de dados secundários, utilizei dados secundários, neste caso dados globais de fertilidade e poluição do ar. Contribui ainda para a construção da estrutura da narrativa do capítulo, particularmente para as considerações finais. O livro foi publicado em 2015. A seguir apresento o capítulo na íntegra. 


\title{
Chapter 2 \\ Impacts of Air Pollution on Reproductive Health
}

\author{
Mariana Matera Veras, Natália de Souza Xavier Costa, \\ Laís Fajersztajn, and Paulo Hilário Nascimento Saldiva
}

\subsection{Introduction}

Humans are continuously exposed to mixtures of environmental contaminants and a vast body of evidence now link exposure to these chemicals with an increased incidence of reproductive and developmental disorders (Woodruff and Walker 2008; Sadeu et al. 2010).

Since the second half of the twentieth century, the harmful effects of air pollution on human health have been the subject of many studies. Episodes of high levels of air pollution experienced by cities in Europe and the United States have enlightened both government agencies and the global community public about the harmful effects of air pollution on human health. Infamous examples include both the London Fog of 1952 and Donora Smog of 1948 that were associated with significantly elevated rates of hospital admissions and mortality (Logan 1953; Helfand et al. 2001). Similarly the more recent Bophal gas disaster (India, 1984) should also be remembered. In this tragic example, a methyl isocyanate gas leak killed 2,500 people in 5 days and many more were condemned to long-term morbidity including serious reproductive dysfunctions (Sriramachari 2005). Subsequent to these episodes, clean air legislations and other regulatory actions have significantly

M.M. Veras, Ph.D. • P.H.N. Saldiva, M.D., Ph.D. (四)

Laboratory of Experimental Air Pollution (LIM05),

Department of Pathology, School of Medicine, University of São Paulo,

Av Dr Arnaldo 455, Room 1103 1st Floor, São Paulo, São Paulo State 01246-903, Brazil

National Institute for Integrated Analysis of Environmental Risk,

São Paulo, São Paulo State, Brazil

e-mail: pepino@usp.br

N. de S.X. Costa, M.S. • L. Fajersztajn, M.S.

Laboratory of Experimental Air Pollution (LIM05),

Department of Pathology, School of Medicine, University of São Paulo,

Av Dr Arnaldo 455, Room 1103 1st Floor, São Paulo, São Paulo State 01246-903, Brazil

(C) Springer-Verlag London 2015

S.S. Nadadur, J.W. Hollingsworth (eds.), Air Pollution and Health Effects,

Molecular and Integrative Toxicology, DOI 10.1007/978-1-4471-6669-6_2 
reduced ambient air pollution in many regions of the world, especially in both North America and Europe (Chen et al. 2007). Despite successful regulatory oversight, air pollution in urban centers remains a substantial risk factor to global human health.

The respiratory tract is the first system to be in contact with the air pollutants. Respiratory and cardiovascular diseases are the most commonly observed effects associated with exposure to low levels of air pollution followed by neoplasia (Schwartz 2006; Pope et al. 2009; Dockery 2009). Recent studies support that common environmental air pollutants that we contact in our daily life and to which exposures are unavoidable could also affect both reproductive health and fetal development. Exposure to ambient air pollution appears to adversely impact fertility, pregnancy outcomes, and fetal health and development (Maisonet et al. 2004; Parker and Woodruff 2008).

Epidemiological studies suggest the association between exposures to air pollution and impairment of reproductive health. However, these studies also recognize and acknowledge many uncertainties with regard to this association (Slama et al. 2008), such as few evidence of plausible biological mechanisms, limited information on personal exposures, difficulties in linking particulate matter (PM) composition or single constituent to the biological effects (Pope 2000; Chen et al. 2008; Valavanidis et al. 2008; Ren and Tong 2008). Despite the adoption of different study designs and statistical evaluations and the potential of confounding variables (e.g. maternal smoking, gestational age, and socioeconomic factors), and lack of consistency in findings, these epidemiological investigations suggest a causal association.

Epidemiological studies are important to help guide further investigation. However, many unanswered questions remain with regard to the association between air pollution and reproductive health including;

- What are the mechanisms involved in decreased fertility due to the exposure to increased PM concentration?

- Which trimester of pregnancy is most relevant to the impairment of fetal development?

- Which component of the PM presents a higher risk for reduced birth weight?

- Are the mechanisms involved in decreased male fertility the same as in females?

- Could multigenerational exposure to ambient PM concentration present cumulative effects?

Future studies utilizing animal models and carefully designed human clinical investigation will help address the current gap in knowledge. Toxicological and clinical studies are necessary to confirm associations elucidate mechanisms involved, identify most susceptible subgroups, and to create ways to reduce these impacts on human health.

In this chapter, we will focus on the major epidemiological findings, current experimental evidence, and possible molecular mechanisms involved in the impairment of the reproductive process associated with exposure to common urban air pollution. 


\subsection{Urban Air Pollution}

Air pollution is a widespread environmental contaminant. Expansion of industry and vehicular traffic has had a major impact on the overall air quality in urban areas over the last decades. This contributed to widespread contamination of the environment by thousands of harmful compounds derived from exhaust emissions. In a broad sense, air pollution can be defined as a mixture of gaseous, liquid, and solid substances containing many toxic components which include; $\mathrm{CO}, \mathrm{NO}_{2}, \mathrm{SO}_{2}$, $\mathrm{O}_{3}, \mathrm{~Pb}$, polycyclic aromatic hydrocarbons $(\mathrm{PAH})$ and particulate matter $(\mathrm{PM})$ (WHO 2005).

Because of the recognized health impacts, significant efforts have been placed on investigation and regulation of the particulate fraction of air pollution. As defined by Collbeck and Lazaridis (2010), particulate matter (PM) is a complex mixture of solid particles, liquid droplets, and liquid components contained in the solid particles constituted by many different chemical species originating from a wide variety of sources. Particles can be produced by combustion, suspension of soil material, and also from chemical reactions in the atmosphere. Nitrates, sulphates, elemental carbon, organic substances (VOC, PAH), metals (Cd, $\mathrm{Pb}$ ) and mineral material (Al, SI, Fe and Ca) are major constituents of airborne PM (Colbeck and Lazaridis 2010; Heal et al. 2012). Particle size ranges vary considerably from a few nanometers (nm) to several micrometers (um), which strongly determine particle lifetime in the atmosphere and deposition in the respiratory tract.

The particles are classified according to their aerodynamic diameter, as $\mathrm{PM}_{10}$ [particles with an aerodynamic diameter smaller than $10 \mu \mathrm{m}$ ], $\mathrm{PM}_{2.5}$ [aerodynamic diameter smaller than $2.5 \mu \mathrm{m}$ ] and $\mathrm{PM}_{0.1}$ [aerodynamic diameter smaller than $0.1 \mu \mathrm{m}$ ] (Colbeck and Lazaridis 2010). The size and its composition are directly linked to negative health effects. The observed high toxicity of the smaller size fractions is believed to be due to the fact that they may reach the deeper portion of the lungs and may translocate into the circulation. Further these fractions contain higher concentrations of polycyclic aromatic hydrocarbons (PAH), semiquinones, metals, transition metals, and have a higher radical generating capacity (Squadrito et al. 2001; Kok et al. 2006).

\subsection{Epidemiological Findings}

The evidence for harmful effects at realistic urban air concentrations of air pollutants predominantly come from epidemiological studies (Slama et al. 2008; Stillerman et al. 2008). In this section, we will present recent reports that indicate that exposures to ambient levels of air pollutants ( $\mathrm{PM}, \mathrm{NO}_{2} \mathrm{SO}_{2}$ and $\mathrm{O}_{3}$ ), in addition to the recognized adverse cardio respiratory effect are associated with negative impacts on reproductive health. 
Increased risks for low birth weight, prematurity, neonatal and post-neonatal mortality and congenital defects have been reported to be associated with exposures to ambient air pollution. Beyond the recognized adverse consequences on pregnancy outcomes, exposure to air pollution is associated with adverse impact on reproductive function including fertility. Furthermore, studies have shown that periods of elevated air pollution were significantly associated with changes in semen quality and damages in sperm DNA (Dejmek et al. 2000; Rubes et al. 2005).

\subsubsection{Fertility and Fecundability}

Very few studies have addressed the effects of ambient air pollution on human fertility. Available studies focus on the primarily impact on male fertility, probably due to readily accessible semen acquisition and analysis (Sokol et al. 2006). Detrimental changes in various semen parameters such as motility, sperm morphology, and DNA are reported, which may cause reduced fertility in males or miscarriage in females.

The positive association of the adverse effects of air pollution exposures on pregnancy outcomes has redirected the attention of the researchers to other important aspects of reproductive health including fertility. One of the first studies that investigated the effects of air pollution on fertility was conducted by Djemek et al. (2000). In this study, they have evaluated the impact of $\mathrm{SO}_{2}$ on fecundability (the probability of conceiving during the menstrual cycle) in the first unprotected menstrual cycle (FUMC) of 2,585 parental pair in a heavily polluted region of Northern Bohemia. They found that adjusted odds ratios of conception in the FUMC may be reduced in couples exposed to mean $\mathrm{SO}_{2}$ levels $>40 \mathrm{pg} / \mathrm{m}^{3}$ in the second month before conception. In a previous study with the same population, they have also found an association between $\mathrm{PM}_{10}$ and reduced conception rates (Dejmek et al. 1998). Slama et al. (2013) reanalyzed the data of the study by Dejmek et al. (2000) and defined the exposure window with respect of the start of the period of unprotected intercourse and considered the impact of $\mathrm{PM}_{2.5}$, carcinogenic polycyclic aromatic hydrocarbons (c-PAH), ozone $\left(\mathrm{O}_{3}\right)$, nitrogen dioxide $\left(\mathrm{NO}_{2}\right)$ levels, in addition to $\mathrm{SO}_{2}$ on fecundability. Their new results highlight that $\mathrm{PM}_{2.5}$ and $\mathrm{NO}_{2}$ levels in the 2 months before the end of the first month of unprotected intercourse were associated with decreased fecundability. This observation highlights the important concept of lag time between exposure and observed health consequences.

Selevan et al. (2000) showed that elevated period of air pollution were significantly correlated with changes in various semen parameters of young Czech men including; proportionately fewer motile sperm, less sperm with normal morphology or normal head shape, and proportionately more sperm with abnormal chromatin. Based on this preliminary findings, Rubes et al. (2005) monitored semen quality in a cohort of young Teplice residents over longer periods of time (periods of exposure to both low and high air pollution) and found a significant association between exposure to high levels of air pollution and decreased sperm chromatin integrity. 
In the United States (Salt Lake City), Hammoud et al. (2010) demonstrated that $\mathrm{PM}_{2.5}$ concentration was negatively correlated to sperm motility 2 months and 3 months after exposure, which coincides with the duration of spermatogenesis (72 days). However, a study of Hansen et al. (2010) did not support a consistent pattern of association between $\mathrm{O}_{3}$ and $\mathrm{PM}_{2.5}$. They performed analysis of several measures of semen quality and found only statistically significant adverse association between increased $\mathrm{PM}_{2.5}$ averaged over the 0 - to 90 -day period before semen sampling and an increase in the percentage of sperm with abnormally shaped heads and the percentage of sperm with cytoplasmic droplets. However, after controlling for season and temperature results failed to reach statistical significance.

In the study of Sokol et al. (2006), there was a significant negative correlation between $\mathrm{O}_{3}$ levels (70-90 days before collection) and average sperm concentration, which was maintained after correction for birth date, age at donation, temperature, and seasonality. These epidemiological results are in line with occupational exposures (De Rosa et al. 2003; Guven et al. 2008) and experimental studies of diesel exhaust inhalation and detrimental effects on sperm (Izawa et al. 2007).

There are very limited studies on the impact of air pollution on female fertility. We are aware of only two studies available in the literature on female fertility that were conducted by Perin et al. (2010a, b). These studies evaluated the impact of PM exposure during the follicular phase of the menstrual cycle or during the preconceptional period of women undergoing IVF/ET on early pregnancy loss and miscarriage. Both studies support an association between brief exposure to high levels of PM and the adverse gestational outcomes. This is an area that would likely benefit from additional studies.

Human fertility is declining in different parts of the world for unclear reasons. There are many hypothesis that have been used to explain this observation. Among the most supported causes of worldwide declining fertility are the delay of childbearing by modern women and other changes in social factors. However, there is also a growing incidence of impaired fecundity among young women and men, which cannot be easily explained by societal factors. Nutritional status, obesity, drugs, smoking habits, stress and increasing exposures to environmental pollutants, such as air pollution, are also plausible factors involved in human reduced fertility that deserve more attention.

\subsubsection{Low Vitamin D and Immune System Alterations}

Besides the "visible" effects of air pollution on fetal health, there is growing evidence of the impact of maternal exposure to urban air pollution on "non-visible" fetal outcomes. Serum vitamin D levels in the mother and fetus seems to be affected by air pollution. Vitamin D is scarce in natural food and the main source of vitamin D for humans is its synthesis from 7-dehydrocholesterol upon exposure to UVB solar radiation and conversion to circulating metabolite called 25-hydroxyvitamin D $[25(\mathrm{OH}) \mathrm{D}]$ in the liver. Deficiencies in vitamin D are associated with different 
bone diseases and more recently it has been involved in other diseases including cardiovascular (Kim et al. 2008) and autoimmune diseases (Lange et al. 2009).

In general, low intake of vitamin $\mathrm{D}$ and insufficient exposure to sunlight constitute the main causes of vitamin D deficiency. However, recent studies point out that exposure to air pollution may also contribute to low serum levels of vitamin D in women and in the unborn child as a consequence of maternal deficiency. In the study conducted by Baiz et al. (2012), maternal exposure to ambient urban levels of $\mathrm{NO}_{2}$ and $\mathrm{PM}_{10}$ during the whole pregnancy was a strong predictor of low vitamin $\mathrm{D}$ status in newborns. Moreover, Kelishadi et al. (2013) have also found that air quality had an inverse and independent association with $25(\mathrm{OH}) \mathrm{D}$ levels of mothers and their neonates and Hosseinpanah et al. (2010) have shown that deficiency in vitamin $\mathrm{D}$ to be prior to pregnancy. In their study, they found that women living in polluted areas present with lower levels of serum 25-OH-D which is comparable to vitamin $\mathrm{D}$ deficiency.

Potential mechanisms that could explain this relationship are based on the impact of smoking on vitamin D status (Brot et al. 1999). It has been suggested that changes in inflammatory profile and oxidative stress caused by smoking affects liver function and hence vitamin D synthesis or affecting maternal intestinal absorption of vital vitamins and minerals (Need et al. 2002). Exposure to air pollutants may have similar impact on vitamin D status. Beyond observed differences in vitamin D, exposure to air pollution could result in changes of the immune system including; NK, T lymphocytes, and IgE content of umbilical blood (Herr et al. 2010, 2011). Maternal exposure to air pollution could have lasting effects of either gestational or pre-gestational exposures on their offspring. The consequences for the future health of these individuals remains unknown, but these effects could have far reaching impacts.

\subsubsection{Gestational Outcomes}

Studies conducted in different continents (Europe, Asia and Americas) consistently report that expectant mothers exposed to air pollution have greater risks of having negative gestational outcomes (Gouveia et al. 2004; Ha et al. 2001; Wang et al. 1997). However, it is not clear from the studies whether the effects are due to a specific pollutant or to the interactions of different pollutants and in which trimester exposures are more detrimental to fetal development. Negative gestational outcomes are predominant reproductive effects associated with exposures to ambient air pollution and are discussed in detail in Chap. 3. In this section, we will briefly highlight the gestational outcomes and its association with criteria pollutants in order to compare with experimental evidence.

The causes of the negative pregnancy outcomes are not well understood but it is clear that these outcomes have multifactorial causes and there are scientific evidence that environmental factor, such as air pollution, can contribute or aggravate these outcomes. Furthermore, there are groups within population that may be more susceptible to air pollution exposure. These groups include individuals with 
preexisting circulatory and respiratory conditions and those socially and economically disadvantaged. In general people with low social and economic status live in more polluted areas, lack adequate health care, and spend more time near high traffic roads that may increase exposures to air pollutants and consequently increase the risks of adverse birth outcomes (Woodruff et al. 2003; O'Neill et al. 2003; Ponce et al. 2005; Gilbert et al. 2007; Ono et al. 2013).

\subsubsection{Low Birth Weight}

The prevalence of low birth weight (LBW), as defined by WHO as weight at birth of less than $2,500 \mathrm{~g}(5.5 \mathrm{lb})$ is estimated to be $15 \%$ worldwide with a range of 3.3-38\% (http://www.who.int/nutrition/topics/lbw_strategy_background.pdf) and occurs mostly in developing countries; coincidentally these countries has elevated levels of air pollution (http://www.who.int/gho/phe/outdoor_air_pollution/phe_012. jpg). This topic is covered in more detail in Chap. 3.

Birth weight is an important indicator of subsequent health issues; low-birthweight babies are more prone to develop hypertension, coronary heart disease, and non-insulin-dependent diabetes during adulthood (Osmond and Barker 2000). Evidence from studies conducted in developed and developing countries, China (Wang et al. 1997), Australia (Mannes et al. 2005), Chezec Republic (Dejmek et al. 1999); and USA (Ritz et al. 2000) point out that $\mathrm{PM}_{10}, \mathrm{PM}_{2.5}$ and $\mathrm{SO}_{2}$ are the major pollutants associated with increased risks of LBW. However, other studies verified that exposures during pregnancy to $\mathrm{CO}, \mathrm{O}_{3}$, and $\mathrm{NO}_{2}$ could also be associated with LBW (Morello-Frosch et al. 2010).

\subsubsection{Preterm Birth, Intrauterine and Neonatal Mortality}

Although less frequently reported, intrauterine and neonatal mortality and pre-term birth (PTB) (Glinianaia et al. 2004; Maisonet et al. 2001; Srám et al. 2005) are also outcomes associated with air pollution. Maternal first trimester exposure to ambient air pollutant exposure seems to be the critical period for PTB. However, Huynh et al. (2006) observed no association between PTB and ambient air $\mathrm{PM}_{2.5}$ levels near the maternal residence during early pregnancy and late gestation.

In Australia, Hansen et al. (2006) observed that increased levels of $\mathrm{O}_{3}, \mathrm{NO}_{2}$ and $\mathrm{SO}_{2}$ during 1st trimester increases the risk of PTB (OR $=1.26,95 \%$ CI 1.10-1.45). Another study from Korea (Leem et al. 2006) reported that increased levels of CO level during 1st trimester are responsible for the increased risk for PTB [OR $=1.26$, $95 \%$ CI 1.11-1.44, p-trend<.001]. Considering traffic proximity, the risk of PTB in Taiwan was elevated among women living close to a major freeway $[<0.5 \mathrm{vs.}$ $0.5-1.5 \mathrm{~km}, \mathrm{OR}=1.30,95 \% \mathrm{CI} 1.03-1.65$ ] (Yang et al. 2003). In Los Angeles, Wilhelm and Ritz (2003) found that there was a dose-response relationship between preterm birth and inverse-distance-weighted traffic density among women in their 3rd trimester [OR $=1.15,95 \% \mathrm{CI} 1.05-1.26]$. 


\subsubsection{Fetal Growth and Developmental Abnormalities}

Although evidence is less consistent, exposures accrued during gestation and sensitive periods of fetal organ development may be related to developmental abnormalities/congenital defects. Jedrychowski et al. (2004) observed that not only birth weight is affected; changes in other anthropometric measurements were observed, such as reduction in head circumference. Studies conducted by van den Hooven et al. (2012a) using ultrasound measurements observed that $\mathrm{NO}_{2}$ levels were inversely associated with fetal femur length in the second and third trimester, and both $\mathrm{PM}_{10}$ and $\mathrm{NO}_{2}$ levels both were associated with smaller fetal head circumference in the third trimester. Vrijheid et al. (2011) systematically reviewed epidemiologic studies on ambient air pollution and congenital anomalies and conducted a meta-analysis for a number of air pollutant-anomaly combinations. They conducted meta-analyses for 18 combinations of pollutants and cardiac anomaly groups and found that $\mathrm{NO}_{2}$ and $\mathrm{SO}_{2}$ exposures were related to increases in the risk of coarctation of the aorta and tetralogy of Fallot and $\mathrm{PM}_{10}$ exposure was related to an increased risk of atrial septal defects.

A large case-control study conducted in California reported a weak association between cleft lip/palate and ambient air $\mathrm{O}_{3}$ levels near the maternal residence during the second month of gestation. Few studies evaluated if there were associations between maternal exposure to air pollutants and stillbirths. Results from these studies remain inconclusive. Pereira et al. (1998) found an association between daily counts of intrauterine mortality and $\mathrm{NO}_{2}, \mathrm{SO}_{2}$, and $\mathrm{CO}$ concentrations before ( $\leq 5$ days) delivery. Similarly, Faiz et al. (2013) reported that increased stillbirth is associated with increases in $\mathrm{NO}_{2}, \mathrm{SO}_{2}, \mathrm{CO}$, and $\mathrm{PM}_{2.5}$ concentrations in the immediate few days before delivery. In a study by Bobak and Leon (1999) stillbirth rates were not significantly associated with any indicator of air pollution.

\subsubsection{Preeclampsia}

Emerging evidence from a large European study and from three previous studies (Woodruff et al. 2008; Wu et al. 2009; Rudra et al. 2011; Olsson et al. 2013) further indicates that that there is also a positive associations between exposure to air pollution and risks of preeclampsia. However, the studies diverge to in terms of the pollutant associated with preeclampsia. In the largest study conducted in Europe, Olsson et al. (2013) found that exposure to $\mathrm{O}_{3}$ in the first trimester of gestation are associated with increased risks of preeclampsia. Rudra et al. (2011) found a weak association between $\mathrm{CO}$ exposure during the first 7 months of pregnancy (per $0.1 \mathrm{ppm})$ and preeclampsia $(\mathrm{OR}=1.07,95 \%, \mathrm{CI}=1.02-1.13)$. In another study conducted in the USA, Wu et al. (2009) reported odds ratios of $1.33(95 \%, \mathrm{CI}=1.18$ $1.49)$ and $1.42(95 \% \mathrm{CI}=1.26-1.59)$ for preeclampsia in the highest exposure quartiles for $\mathrm{NO}_{\mathrm{x}}$ and $\mathrm{PM}_{2.5}$. Increased blood pressure throughout pregnancy has also been observed in mothers who are exposed to air pollution (van den Hooven et al. 2012b; Lee et al. 2013) and both available studies agree that $\mathrm{PM}_{10}$ and $\mathrm{O}_{3}$ are associated to this effect. 


\subsubsection{Secondary Sex Ratio}

In the literature, there are many examples of studies suggesting the impact of both environmental pollution and occupational exposure to certain substances and changes in secondary sex ratio (SSR) (Terrell et al. 2011; Tragaki and Lasaridi 2009; Schnorr et al. 2001). Previous studies have shown changes in sex ratios of populations living near incinerators [lower sex ratio] (Williams et al. 1992) as well as in areas exposed to polluted air from steel foundries (higher sex ratio) (Lloyd et al. 1985). In urban areas with high levels of particulate pollution derived from traffic, there is only one study that investigated if the secondary sex ratio could be affected by air pollution. In this study, Miraglia et al. (2013) have found a significant negative association between SSR and $\mathrm{PM}_{10}$ concentration in São Paulo city, Brazil. Although the causality between environmental exposures and declines in secondary sex ration are still controversial, some authors suggest that the SSR as a sentinel indicator of reproductive injury (Davis et al. 1998).

\subsubsection{Reproductive System Cancer}

Little is known about the role of air pollution in cancers of the reproductive system cancer (e.g. prostate, ovarian and breast cancer). However, an increased risk of lung cancer associated with exposures to outdoor air pollution was consistently observed in studies from Europe, North America, and Asia (Fajersztajn et al. 2013). Thus it is reasonable to suspect that other types of cancer could be caused by long term exposure to air pollutants. The latest IARC release on cancer incidence mortality and prevalence worldwide predict a substantive increase to total 19.3 million new cancer cases per year by 2025 , due to growth and ageing of the global population. However, environmental influences and lifestyle factors may also be implicated in this increase; and they highlight the fact that breast cancer incidence has increased by more than $20 \%$. Vehicular emission is the primary contributor to air pollution in urban areas, its composition include compounds that are recognized as carcinogens, such as diesel exhaust. Recently, the International Agency for Research on Cancer (IARC) of the World Health Organization has classified diesel and gasoline exhaust as carcinogenic to humans as possibly carcinogenic (Loomis et al. 2013).

Few studies have been conducted to evaluate if there is an association between reproductive system cancer and air pollution. These types of studies are limited by difficulties in the assessment of long term exposures, the presence of a myriad of confounding factors and co-exposures to other known carcinogens in food and water. Disinfection by products and even infections make it difficult the establishment strong associations between air pollution and cancer risk factors.

Prostate Cancer There are only two studies in the literature that found an association between prostate cancer and air pollution (Soll-Johanning and Bach 2004; Parent et al. 2013). Recently, a case-control study conducted in Montreal evaluated environmental risk factors for prostate cancer and found associations between 
exposures to traffic related air pollution, assessed by exposures to $\mathrm{NO}_{2}$, and increased risks of prostate cancer incidence. Limitations of the study include exposure assessment based on home address and time of exposure which was 25 years prior to the interview and thus which could misclassify an individual's exposure (Parent et al. 2013).

Breast Cancer In women, breast cancer has the highest incidence rate. Many risk factors have been pointed out such as genetic factors, lifestyle, reproductive history, smoking and alcohol consumption. Although many factors have been identified most of the cases remain with unknown etiology (Coyle 2004). The first evidence of a possible relationship between breast cancer and air pollution levels came from the observation that the incidence was higher in urban areas compared to rural areas (Bako et al. 1984; Hall et al. 2005; Reynolds et al. 2004). Human studies are limited, however there at least 30 substances present in urban air pollution that are known to be associated with increased mammary tumors in animals such as benzene (diesel exhaust) and polycyclic aromatic hydrocarbons (PAHs). Thus, it is plausible that traffic-related exposures may contribute to the incidence of breast cancer (reviewed by Rudel et al. 2007). In the USA, few studies assessed the relationship between air pollution exposure and breast cancer. Lewis-Michl et al. (1996) conducted a case-control interview study in New York (USA) and suggested a possible increased risk $[\mathrm{OR}=1.29 ; 95 \% \mathrm{CI}: 0.77-2.15]$ of breast cancer among postmenopausal women who live near areas with high traffic density. Bonner et al. (2005) found that early-life exposures to relatively high concentrations of air pollution (i.e., $>140 \mu \mathrm{g} / \mathrm{m}^{3}$ ) were associated with an increased risk of developing postmenopausal breast cancer $(\mathrm{OR}=2.42 ; 95 \% \mathrm{CI}, 0.97-6.09)$. In Canada, Crouse et al. ( 2010) found evidence of an association between the incidence of postmenopausal breast cancer and exposure to ambient concentrations of $\mathrm{NO}_{2}$. In China, Huo et al. (2013) have shown that long-term air pollution exposure may contribute to the development of breast cancer.

Ovary Cancer In the literature, there are only two studies that have found an association between air pollution and ovarian cancer. In the first study published in 2005, Iwai et al. (2005) conducted a cross-sectional epidemiological study using the annual vital statistics and air pollution throughout Japan and found that breast, endometrial, and ovarian cancer showed significant increases in mortality rates in relation to particulate pollution. More recently in Taiwan, Hung et al. (2012) showed that individuals who resided in municipalities with higher $\mathrm{PM}_{2.5}$ levels were at a significantly increased risk of death from ovarian cancer.

\subsection{Experimental Evidence}

All of the published studies acknowledged that there are many uncertainties on the association between adverse reproductive outcomes and air pollution (Pope 2000; Chen et al. 2008; Valavanidis et al. 2008; Ren and Tong 2008). Undoubtedly these 
aspects point out that there is a need for further toxicological and clinical studies to confirm, to strengthen and elucidate the mechanism involved in this association, to identify most susceptible subgroups and to create ways to reduce these impacts on human health. The scientific literature is extremely scarce with regard to experimental studies conducted to evaluate reproductive efficiency using laboratory animals exposed to real urban air pollution. Available studies conducted on experimental animals, mainly mice, have corroborated human epidemiological data and have provided data showing additional effects not yet investigated in humans.

Studies using a multigenerational mouse model of exposure to "real world" ambient concentrations of air pollution, (i.e. mice mates and their litters were continuously exposed inside chambers to either filtered-clean air or non-filtered airpolluted air), found that urban air pollution compromises reproductive health in different ways across generations. This series of studies has shown that in the first generation (G1) of mice exposed to air pollution there were significant reductions in the number of viable fetuses, increased numbers of implantation failures, and a decreased male/female secondary sex ratio (Mohallem et al. 2005; Lichtenfels et al. 2007). In the second generation of mice (G2), females exposed to air pollution during gestation gave birth to litters with reduced birth weights, but no differences in litter size and viable fetuses were observed. Birth weight was significantly lower with a mean reduction of $21 \%$ compared to fetuses from non-exposed females (Veras et al. 2009).

The negative effect of air pollution exposure during pregnancy and birth outcomes are increasingly recognized, but most epidemiological studies have focused only on exposure during the gestational period. Evidence from animal studies explored the effects of maternal exposure before pregnancy on fetal development and demonstrates that maternal exposure not only during pregnancy, but also before conception, adversely affected fetal birth weight (Veras et al. 2008; Rocha et al. 2008). In the same way, exposure to air pollutants during gestation and/or during the pre-gestational period was associated with increased post-implantation loss rates in exposed females (Veras et al. 2009). These results support the findings from Perin et al. (2010a, b) on the importance of the pre-gestational period on gestation establishment. Examination of the placenta from dams exposed to air pollution before and/or during pregnancy revealed that both pre-pregnancy and pregnancy periods of exposure to polluted air resulted in morphological changes in the placenta (Veras et al. 2008). Veras et al. (2008) found that decreases in fetal weight were accompanied by decreases in the volume of maternal blood spaces, in the mean diameter of maternal blood spaces, and in maternal:fetal surface ratio. These features were accompanied by increases in the surface area of fetal capillaries, the total diffusive conductance of the intervascular barrier, and the massspecific conductance of that barrier. None of the studies conducted in human has evaluated whether placental changes are associated with adverse pregnancy outcomes in humans. Recently, van den Hooven et al. (2012a) using ultrasound measurements and markers of placental growth and function have shown that in human the placenta development, as observed in animals, is impaired by maternal exposure to air pollution. 
Umbilical cords were also evaluated and exposures to air pollution were associated with thinner and less voluminous umbilical cords (loss of mucoid connective tissue and collagen content). Structural changes in umbilical arteries and veins and elevated immunoreactivity for $15-\mathrm{F} 2 \mathrm{t}$-IsoP (oxidative stress), ETAR and ETBR (vascular tone) in their walls were found. Together these findings indicate compromised fetal development evidenced by reduced birth weight might be mediated by alteration in placental and umbilical structure and function as well as by imbalances in the endogenous regulators of vascular tone and oxidative stress (Veras et al. 2012).

The reproductive capacity of G2 nulliparous female mice was also examined and results have shown changes to estrous cyclicity and in ovarian follicle counts (decreased numbers of antral follicles) (Veras et al. 2009). Antral follicles represent the last stage in follicle development prior to ovulation and are the only follicle type capable of releasing an oocyte for fertilization and synthesizing estrogen (Hoyer and Sipes 1996; Hirshfield 1997). Increases in the rate of follicle depletion can potentially raise the possibility of premature ovarian failure and early menopause in the case of humans (Rowe 2006). Observed changes in estrous cyclicity are indicative of persistent estrus, which may reflect an impairment of ovulation as well as changes in the levels of circulating ovarian hormones (EPA 1996).

Further, in the second generation it was observed changes in couple-based outcomes. Couples exposed to air pollution presented decreased fertility indices, decreased pregnancy success and delayed onset of reproductive maturity, as evidenced by extended times to mating (Veras et al. 2009). In humans, air pollution exposures seemed to decrease conception rates (Dejmek et al. 1998). However, we still do not know if the effects are associated with impairments on female or male health.

It is important to point out that the mean concentration of $\mathrm{PM}_{2.5}$ (24-h average concentration) used in some studies $\left(27.5 \mu \mathrm{g} / \mathrm{m}^{3}\right.$, Veras et al. 2008, 2009), is less than the $35 \mu \mathrm{g} / \mathrm{m}^{3}$ established by the U.S. National Ambient Air Quality Standards [US-NAAQS] (http://www.epa.gov/air/criteria.html) and, approximately equivalent to the World Health Organization (WHO) air quality guideline $\left(25 \mu \mathrm{g} / \mathrm{m}^{3}\right.$; WHO 2005 ) raising the question of whether these proposed values are safe for reproductive health.

Two recent mechanistic experimental studies (unpublished) addressed the associations between air pollution exposure during the initial stages of pregnancy in mice and uterine response to embryo implantation. Scoriza et al. (2009) observed that in early pregnancy ( 6 and $8 \mathrm{GD}$ ) that reductions in the number of uterine natural killer (uNKcells) and mast cells could contribute to the increased rates of post implantation losses observed in mice. uNK cells are a subpopulation of lymphocytes that in normal mice promote decidual angiogenesis, trophoblast and placental cell growth, provide immunomodulation at the maternal-fetal interface for a healthy pregnancy (Bilinski et al. 2008). The role of mast cells in pregnancy is less known. However, during normal early pregnancy, the number of mast cells and their activation change (Gibbons and Chang 1972; Marx et al. 1999). These data suggest that components present in air pollution may indirectly interfere with or impair 
embryonic development through changes to the maternal environment including maternal immune responses. In another study, nulliparous mice were exposed to two different doses of fine particulate air pollution $\left(\mathrm{PM}_{2.5}\right)$ for 45 days before pregnancy until gestational day 4 and expression of different uterine receptivity markers were evaluated (Lif, leukemia inhibitory factor; and $M u c 1$, mucin, pinopods) as well as uterine histopathology. Histopathology revealed a decrease in the volume and thickness of the endometrium as well as changes in the diameter and thickness of the glandular and luminal epithelia. No significant alteration was observed in the expression (qPCR/IHC) of $M u c 1$ but there was significant suppression of Lif during the window of implantation. These findings suggest that air pollutants may affect the fine regulation of proliferation and differentiation of uterine stromal cells during decidualization via reduced LIF expression (Castro et al. 2013).

Evidences from experimental studies linking and chronic exposure to air pollution are in line with the epidemiological findings (Knottnerus et al. 1990; Peters et al. 1997; Pekkanen et al. 2000). However, the mechanisms involved in this association are not clearly known. There are many suggested potential mechanisms which include induction of p450 enzymes, DNA damage, and systemic alterations in hematocrit, blood viscosity, blood coagulation, endothelial dysfunction, oxidative stress, and inflammation (Baskurt et al. 1990; Sørensen et al. 2003; Andrysík et al. 2011). The mechanisms proposed are described in more detail in the next section.

\subsection{Biological Mechanisms}

The mechanisms, by which, air pollution could cause adverse health effects are characterized by their ability to directly act as pro-oxidants of lipids and proteins or as free radical generators, promoting oxidative stress, inflammatory responses and damage to mitochondrial function (Menzel 1994; Rahman and MacNee 2000; Li et al. 2003).

The first system to in contact with air pollution is the respiratory tract. Epidemiologic and experimental data show that the air pollution can cause pulmonary inflammation, decrease of pulmonary function, and aggravation of pre-existing pulmonary diseases such as asthma and bronchitis (Laumbach 2010; Saldiva et al. 2002; Seaton et al. 1995).

The bigger fraction of the PM gets trapped on the superior respiratory tract, and the smaller fraction can reach the lungs and these particles can be deposited (Amdur and Corn 1963; Amdur and Creasia 1966). In an attempt to remove such particles, alveolar macrophages phagocytize the particles, penetrating into the cellular interstitium, but part of these fine particles can be translocate across the air-blood barrier into circulation and towards secondary target organs, suggesting that the smaller the particle diameter, the greater the possibility of translocation to other organs (Takenaka et al. 1986; Ferin et al. 1992; Oberdorster and Utell 2002; Chen et al. 2006). 
The majority of fine and ultrafine $\left(<\mathrm{PM}_{0.1}\right)$ particles found in the urban atmosphere derive from engine combustion. Ultrafine particles have very low mass typically with magnitudes higher particle numbers and therefore a high surface area relative to fine and coarse particles for adsorption of toxic species (Sioutas et al. 2005). Studies suggest that only a small fraction of PM can pass rapidly into systemic circulation, and that pulmonary inflammation seems to play a major role in enhancing the extra-pulmonary translocation of particles (Chen et al. 2006; Brown et al. 2002; Burch 2002; Mills et al. 2006; Wiebert et al. 2006a, b; Möller et al. 2008). Organic components of particles, which comprise a large proportion of freshly emitted exhaust and secondary aerosols, can induce a broad polyclonal expression of cytokines and chemokines in respiratory epithelium and this effect may be due to the action of PAHs, metals and related compounds that lead to the production of cytotoxic reactive oxygen species (ROS); and these inflammatory and oxidant stress responses are expected to occur at extra-pulmonary sites, as well (Sioutas et al. 2005; Ritz and Wilhelm 2008).

Several hypotheses have been proposed that air pollution can affect the reproductive system causing negative effects, such as impairment of male and female reproductive capacity, placental alterations and fetal health.

As we have previously described, exposure to air pollution is associated with detrimental pregnancy outcomes and these outcomes can be caused by a combination of maternal, fetal, and placental factors or a combination of them. . For example, air pollution can affect the utero-placental and umbilical cord flow and consequently the transport for glucose and oxygen though the placenta (Veras et al. 2008, 2012; Ritz and Wilhelm 2008; Vorherr 1982).

According to the review of Kannan and collaborators (Kannan et al. 2006, 2007), the particulate matter present on the air pollution can affect pregnancy outcomes due to:

- Increase in oxidative stress: an important mechanism of action PM can be the DNA damage induced by oxidative stress, also some metals in PM may inhibit the DNA repair enzymes.

- Inflammation: Inflammation could be associated with inadequate placental perfusion and impaired transplacental nutrient exchange, which may cause growth restriction in utero due to interference with some process or processes such as affecting nutrition of the fetus, reduced oxygenation of maternal blood, or both.

- Coagulation and blood pressure: PM exposures may increase any of the proteins of the clotting cascade, indicating a higher possibility for coagulation and may also lead to changes in hemoglobin, platelets, and white blood cells, which may potentially contribute to adverse fetal growth. PM exposure is also associated with elevations on the blood pressure in pregnant women and this could increase the risk of adverse outcomes, especially if there is preexisting hypertension (pregnancy-induced or not). Elevation of blood pressure in pregnant women has been associated with IUGR and preterm delivery.

- Hemodynamic responses: an impaired adaptation of maternal hemodynamic may lead to an impaired fetal growth. These changes may force the fetus to 
adapt, down-regulate growth, and prioritize the development of essential tissues.

- Endothelial function: PM exposure may cause endothelial dysfunctions leading to vasoconstriction and could be considered as an intervening pathway in subsequent impact on fetal growth.

These pathways may or may not act independently, but it is more likely that the outcomes of the exposure to air pollution are an association among these pathways and they are probably related to the composition of the particulate matter (Saldiva et al. 2002).

There are evidences that the air pollution can affect not only the pregnancy but also the male and female reproductive fertility (Somers and Cooper 2009).

Based on epidemiological studies it was observed that exposure to air pollution affects fertility rates (Dejmek et al. 2000; Selevan et al. 2000) at different seminal parameters, motility and morphology and the sperm DNA (Rubes et al. 2005; Hansen et al. 2010; Jafarabadi 2007).

In a study conducted by Somers et al. (2002), a significant elevation in mutation frequency was reported in the offspring of animals exposed to air pollution; primarily through expanded simple tandem repeat (ESTR) DNA loci mutation events in the paternal germline.

In other studies conducted by Somers et al. (2004) and Yauk et al. (2008), they noted that ESTR mutation frequencies were also elevated the paternal germline of mice exposed to whole ambient air at the polluted industrial site, indicating that mutations were induced in spermatogonial stem cells. Maternal ESTR mutation frequencies were similar in all groups, and therefore unaffected by air pollution exposure (Somers et al. 2004). Bulky DNA adducts were not significant, suggesting that DNA reactive chemicals do not reach the germ line and cause ESTR mutation. In contrast, DNA strand breaks were elevated after 3 weeks of exposure, possibly resulting from oxidative stress arising from exposure to air pollution and its particulate matter (Yauk et al. 2008).

Sperm DNA in mice exposed to whole ambient air was globally hypermethylated compared to those exposed to filtered air. These methylation changes appeared early in the environmental exposure and were still present after 6 weeks without the air pollution exposure. Persistent changes in the methylation status of genes may have health implications for the next generation through altered gene expression (Somers et al. 2004; Yauk et al. 2008).

Environmental toxicants can alter the female reproduction by direct mechanisms (hormone disruptors) or indirect (immunological toxicants). Direct effects typically occur if an environmental chemical is structurally similar to a molecule capable of interacting with endogenous reproductive organs. Indirect effects can occur if a chemical interferes with the hormonal action. Natural hormones are critical for development, behavior, puberty beginning, sexual function, and gametogenesis. Some environmental chemicals can mimic or block the action of the natural hormone, thus negatively altering reproductive processes (McLachlan and Arnold 1996). 
As steroid hormones, some environmental toxicants are lipo-soluble and cross the cell membrane by passive diffusion, thereby allowing access to any animal cell. Once these chemicals cross the cell membrane, which may interact with steroid receptors, access to the nucleus as a dimer hormone-receptor induces the activation or suppression of genes causing a biological response (McLachlan and Arnold 1996).

Several compounds present in air pollution (heavy metals, environmental oestrogens, diesel and PAHs) are able to suppress or interfere with the regulation of the hypothalamic-pituitary-gonadal axis; resulting in changes in growth and development of ovarian follicles and estrous cyclicity (Veras et al. 2009; Mamatsashvili 1970; Borgeest et al. 2004), affecting the whole process of pregnancy, including signaling pathways between the conceptus-mother or, the uterus preparation for implantation (Hoyer and Sipes 1996; Mattison and Thomford 1989; Tsukue et al. 2001; Takeda et al. 2004; Telisman et al. 2007). However, the specific contaminants that caused sperm damage and the potential impact on fertility or pregnancy outcomes were undetermined (Somers 2011).

PAHs in air pollution have the capacity to bind to steroid receptors, mimicking their action, and thus altering the production of these hormones, which can result in adverse consequences for the development and reproductive health (Kristensen et al. 1995; Wenger et al. 2009; Han et al. 2010). For example, Hood (2006) in his study suggests that exposure prior to conception, both female as male, can lead to a hormonal dysregulation causing direct damage to the reproductive organs and gametes.

Studies suggest that PAHs are able to cross the placenta and reach fetal organs causing adverse reproductive outcomes, including; stillbirths, reabsorptions, congenital abnormalities, and decreases in fetal weight. The exposure to PAHs may lead to increased DNA adducts, resulting to LBW and intrauterine growth restriction. Furthermore, the PM may bind receptors for placental growth factors leading to decreased fetal-placental exchange of oxygen and nutrients (Dejmek et al. 2000; Ritz and Wilhelm 2008).

\subsection{Prevention}

There are sufficient evidence of the harmful effects of exposures to environmental air pollution on reproductive health. Furthermore, it is clear that increased levels of air pollution are found in developing and underdeveloped countries in regions with high population density and higher fertility rates (Fig. 2.1). Although the risks associated with the negative reproductive outcomes tend to be small, the number of people that might be affected is significantly large. Furthermore, if we consider that negative influence on the initial stages of life (embryo/fetus) increases the risks of later life diseases, such as diabetes, metabolic syndromes and cardiovascular diseases (Osmond and Barker 2000; Gluckman and Hanson 2004) exposures to air pollution during pregnancy would have a profound impact in public health strategies to prevent most common health issues 


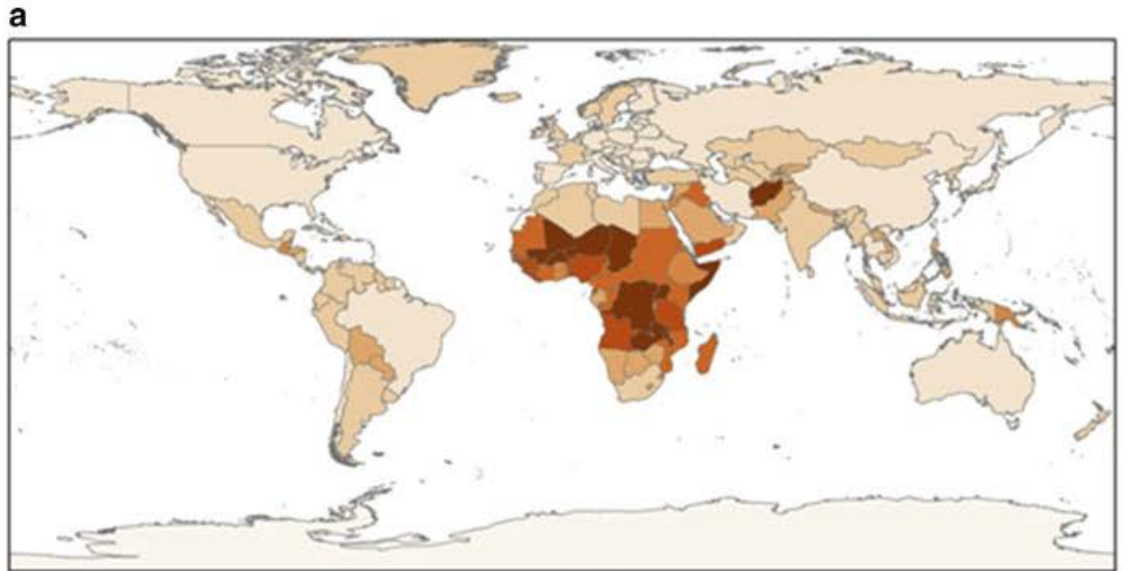

Fertility rate, total births (per woman)
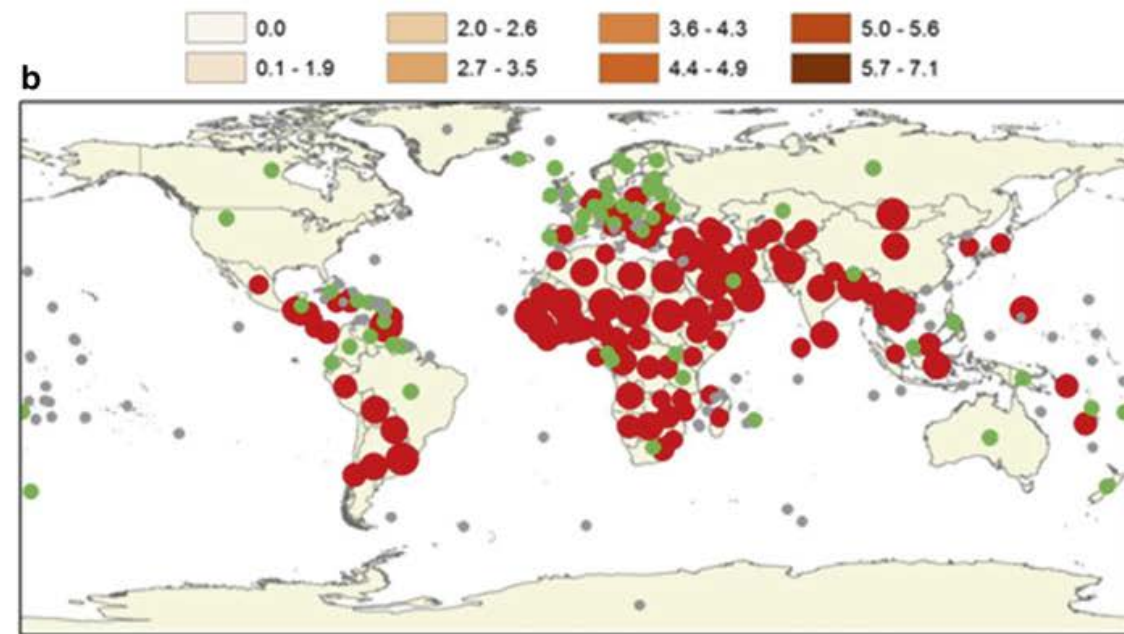

PM10 ( $\mu$ g per $\mathrm{m} 3$ )

$\begin{array}{llll}\text { no data } & 21.30 & 51.70 \\ -6.20 & 31.50 & 71.137\end{array}$

Fig. 2.1 Global scenario of gestational exposure to air pollution. The map compares the total births per women in 2009 (data from the World Bank) (a) (World Bank 2013a) with the annual mean concentration of particulate matter of $10 \mu \mathrm{m}$ or less (PM10) in the same year (data from the World Bank) (b) (World Bank 2013b), showing that reproductive health consequences from air pollution exposure is a major concem in the developing nations where a growing population is being exposed to levels of particulate air pollution above the $\mathrm{WHO}$ recommended limits 
The most effective way to reduce health risks associated with air pollution is to implement air quality management strategies and National Air Quality Standards (Thurston and Balmes 2012). The U.S. Environmental Protection Agency (EPA) projections that by 2020 adherence to the Clean Air Act standard for ozone alone will prevent 230 million premature deaths and 280 infant-mortalities (EPA 2011). Indeed, increasingly stringent (NAQS) already proved effectiveness in improving air quality in the United States and Western Europe in recent decades (Van Erp et al. 2008) and a global analysis concluded that flexible air quality standards lead to higher air pollution concentrations (Vahlsing and Smith 2012).

\subsection{Concluding Remarks}

Epidemiologic and experimental evidences converge to indicate that air pollution, at the current levels, play a deleterious role on reproductive function. In addition to the scientific questions raised from the aforementioned evidences presented in this chapter - which are the mechanisms, which are the most important pollutants or are the observed effects the result of a mixture of mixtures - some ethical considerations emerged at this moment. Indeed, the options of energy use, industrial production and mobility made by our and our preceding generations, may be affecting those that did not participate in the decision process. Moreover, there is a marked contrast in ambient air pollution concentrations, creating an uneven attributable risk across the globe. As a general rule, air pollution is the result of bad technologies, usually present in the less privileged countries. These points deserve serious consideration when translating knowledge into public policies aimed to protect children globally.

\section{References}

Amdur MO, Corn M (1963) The irritant potency of zinc ammonium sulfate of different particle sizes. Am Ind Hyg Assoc J 24:326-333

Amdur MO, Creasia DA (1966) The irritant potency of m-terphenyl of different particle sizes. Am Ind Hyg Assoc J 27(4):349-352

Andrysík Z, Vondráček J, Marvanová S, Ciganek M, Neča J, Pěnčíková K, Mahadevan B, Topinka J, Baird WM, Kozubík A, Machala M (2011) Activation of the aryl hydrocarbon receptor is the major toxic mode of action of an organic extract of a reference urban dust particulate matter mixture: the role of polycyclic aromatic hydrocarbons. Mutat Res 714(1-2):53-62

Baïz N, Dargent-Molina P, Wark JD, Souberbielle JC, Slama R, Annesi-Maesano I, EDEN MotherChild Cohort Study Group (2012) Gestational exposure to urban air pollution related to a decrease in cord blood vitamin D levels. J Clin Endocrinol Metab 97(11):4087-4095

Bako G, Dewar R, Hanson J, Hill G (1984) Population density as an indicator of urban-rural differences in cancer incidence, Alberta, Canada, 1969-73. Can J Public Health 75(2):152-156

Baskurt OK, Levi E, Caglayan S, Dikmenoglu N, Kutman MN (1990) Hematological and hemorheological effects of air pollution. Arch Environ Health 45:224-228 
Bilinski MJ, Thorne JG, Oh MJ, Leonard S, Murrant C, Tayade C, Croy BA (2008) Uterine NK cells in murine pregnancy. Reprod Biomed Online 16(2):218-226

Bobak M, Leon DA (1999) Pregnancy outcomes and outdoor air pollution: an ecological study in districts of the Czech Republic 1986-8. Occup Environ Med 56(8):539-543

Bonner MR, Han D, Nie J, Rogerson P, Vena JE, Muti P, Trevisan M, Edge SB, Freudenheim JL (2005) Breast cancer risk and exposure in early life to polycyclic aromatic hydrocarbons using total suspended particulates as a proxy measure. Cancer Epidemiol Biomarkers Prev 14(1):53-60

Borgeest C, Miller KP, Gupta R, Greenfeld C, Hruska KS, Hoyer P, Flaws JA (2004) Methoxychlorinduced atresia in the mouse involves Bcl-2 family members, but not gonadotropins or estradiol. Biol Reprod 70(6):1828-1835

Brot C, Jorgensen NR, Sorensen OH (1999) The influence of smoking on vitamin D status and calcium metabolism. Eur J Clin Nutr 53:920-926

Brown JS, Zeman KL, Bennett WD (2002) Ultrafine particle deposition and clearance in the healthy and obstructed lung. Am J Respir Crit Care Med 166(9):1240-1247

Burch WM (2002) Passage of inhaled particles into the blood circulation in humans. Circulation 106(20):141-142

Castro KR, Ribeiro R, Peres M, Saldiva P, Matsuda M, Veras M (2013) Murine uterine receptivity markers are affected by particulate air pollution in a dose response manner. Placenta 34(2):A10

Chen J, Tan M, Nemmar A, Song W, Dong M, Zhang G, Li Y (2006) Quantification of extrapulmonary translocation of intratracheal-instilled particles in vivo in rats: effect of lipopolysaccharide. Toxicology 222:195-201

Chen TM, Shofer S, Gokhale J, Kuschner WG (2007) Outdoor air pollution: overview and historical perspective. Am J Med Sci 333(4):230-234

Chen H, Goldberg MS, Villeneuve PJ (2008) A systematic review of the relation between long-term exposure to ambient air pollution and chronic diseases. Rev Environ Health 23(4):243-297

Colbeck I, Lazaridis M (2010) Aerosols and environmental pollution. Naturwissenschaften 97(2): 117-131

Coyle YM (2004) The effect of environment on breast cancer risk. Breast Cancer Res Treat 84(3): $273-288$

Crouse DL, Goldberg MS, Ross NA, Chen H, Labrèche F (2010) Postmenopausal breast cancer is associated with exposure to traffic-related air pollution in Montreal, Canada: a case-control study. Environ Health Perspect 118(11):1578-1583

Davis DL, Gottlieb MB, Stampnitzky JR (1998) Reduced ratio of male to female births in several industrial countries: a sentinel health indicator? JAMA 279(13): 1018-1023

De Rosa M, Zarrilli S, Paesano L, Carbone U, Boggia B, Petretta M et al (2003) Traffic pollutants affect fertility in men. Hum Reprod 18(5):1055-1061

Dejmek J, Jelinek R, Benes I, Sram RJ (1998) Impact of air pollution on human fertility: acute effects of SO2, NOx and PM. Epidemiology 9(4):148

Dejmek J, Selevan SG, Benes I, Solanský I, Srám RJ (1999) Fetal growth and maternal exposure to particulate matter during pregnancy. Environ Health Perspect 107(6):475-480

Dejmek J, Jelínek R, Solansky' I, Benes I, Srám RJ (2000) Fecundability and parental exposure to ambient sulfur dioxide. Environ Health Perspect 108(7):647-654

Dockery DW (2009) Health effects of particulate air pollution. Ann Epidemiol 19(4):257-263

EPA (1996) Guidelines for reproductive toxicity risk assessment. http://www.epa.gov/raf/publications/pdfs/REPRO51.PDF. Accessed 15 June 2013

EPA (2011) Report to congress: the benefits and costs of the Clean Air Act 1990 to 2020. U.S. http://www.epa.gov/oar/sect812/feb11/fullreport_rev_a.pdf. Accessed 2 Aug 2013

Faiz AS, Rhoads GG, Demissie K, Lin Y, Kruse L, Rich DQ (2013) Does ambient air pollution trigger stillbirth? Epidemiol 24(4):538-544

Fajersztajn L, Veras M, Barrozo LV, Saldiva P (2013) Air pollution: a potentially modifiable risk factor for lung cancer. Nat Rev Cancer 13(9):674-678

Ferin J, Oberdörster G, Penney DP (1992) Pulmonary retention of ultrafine and fine particles in rats. Am J Respir Cell Mol Biol 6(5):535-542 
Gibbons AF, Chang MC (1972) Number of mast cells in the rat uterus with special reference to its relation to hormonal treatment and decidual response. Biol Reprod 6:193-203

Gilbert WM, Young AL, Danielsen B (2007) Pregnancy outcomes in women with chronic hypertension: a population-based study. J Reprod Med 52(11):1046-1051

Glinianaia SV, Rankin J, Bell R, Pless-Mulloli T, Howel D (2004) Particulate air pollution and fetal health: a systematic review of the epidemiologic evidence. Epidemiol 15:36-45

Gluckman PD, Hanson MA (2004) Maternal constraint of fetal growth and its consequences. Semin Fetal Neonatal Med 9(5):419-425

Gouveia N, Bremner SA, Novaes HM (2004) Association between ambient air pollution and birth weight in São Paulo, Brazil. J Epidemiol Community Health 58(1):11-17

Guven A, Kayikci A, Cam K, Arbak P, Balbay O, Cam M (2008) Alterations in semen parameters of toll collectors working at motorways: does diesel exposure induce detrimental effects on semen? Andrologia 40(6):346-351

$\mathrm{Ha}$ EH, Hong YC, Lee BE, Woo BH, Schwartz J, Christiani DC (2001) Is air pollution a risk factor for low birth weight in Seoul? Epidemiol 12(6):643-648

Hall SA, Kaufman JS, Millikan RC, Ricketts TC, Herman D, Savitz DA (2005) Urbanization and breast cancer incidence in North Carolina, 1995-1999. Ann Epidemiol 15(10):796-803

Hammoud A, Carrell DT, Gibson M, Sanderson M, Parker-Jones K, Peterson CM (2010) Decreased sperm motility is associated with air pollution in Salt Lake City. Fertil Steril 93(6): 1875-1879

Han Y, Xia Y, Zhu P, Qiao S, Zhao R, Jin N, Wang S, Song L, Fu G, Wang X (2010) Reproductive hormones in relation to polycyclic aromatic hydrocarbon (PAH) metabolites among nonoccupational exposure of males. Sci Total Environ 408(4):768-773

Hansen C, Neller A, Williams G, Simpson R (2006) Maternal exposure to low levels of ambient air pollution and preterm birth in Brisbane, Australia. BJOG 113(8):935-941

Hansen C, Luben TJ, Sacks JD, O1shan A, Jeffay S, Strader L, Perreault SD (2010) The effect of ambient air pollution on sperm quality. Environ Health Perspect 118(2):203-209

Heal MR, Kumar P, Harrison RM (2012) Particles, air quality, policy and health. Chem Soc Rev 41:6606-6630

Helfand WH, Lazarus J, Theerman P (2001) Donora, Pennsylvania: an environmental disaster of the 20th century. Am J Public Health 91:553

Herr CE, Dostal M, Ghosh R, Ashwood P, Lipsett M, Pinkerton KE, Sram R, Hertz-Picciotto I (2010) Air pollution exposure during critical time periods in gestation and alterations in cord blood lymphocyte distribution: a cohort of livebirths. Environ Health 9:46

Herr CE, Ghosh R, Dostal M, Skokanova V, Ashwood P, Lipsett M, Joad JP, Pinkerton KE, Yap PS, Frost JD, Sram R, Hertz-Picciotto I (2011) Exposure to air pollution in critical prenatal time windows and IgE levels in newborns. Pediatr Allergy Immunol 22(1):75-84

Hirshfield AN (1997) Overview of ovarian follicular development: considerations for the toxicologist. Environ Mol Mutagen 29(1):10-15

Hood RD (2006) Developmental and reproductive toxicology: a practical approach, 2nd edn. CRC Press, Boca Raton

Hosseinpanah F, Pour SH, Heibatollahi M, Moghbel N, Asefzade S, Azizi F (2010) The effects of air pollution on vitamin D status in healthy women: a cross sectional study. BMC Public Health $10: 519$

Hoyer PB, Sipes IG (1996) Assessment of follicle destruction in chemical-induced ovarian toxicity. Annu Rev Pharmacol Toxicol 36:307-331

Hung LJ, Chan TF, Wu CH, Chiu HF, Yang CY (2012) Traffic air pollution and risk of death from ovarian cancer in Taiwan: fine particulate matter (PM2.5) as a proxy marker. J Toxicol Environ Health A 75(3): 174-182

Huo Q, Zhang N, Wang X, Jiang L, Ma T, Yang Q (2013) Effects of ambient particulate matter on human breast cancer: is xenogenesis responsible? PLoS One 8(10):e76609. doi:10.1371/journal.pone.0076609. eCollection 2013

Huynh M, Woodruff TJ, Parker JD, Schoendorf KC (2006) Relationships between air pollution and preterm birth in California. Paediatr Perinat Epidemiol 20(6):454-461 
Iwai K, Mizuno S, Miyasaka Y, Mori T (2005) Correlation between suspended particles in the environmental air and causes of disease among inhabitants: cross-sectional studies using the vital statistics and air pollution data in Japan. Environ Res 99(1):106-117

Izawa H, Kohara M, Watanabe G, Taya K, Sagai M (2007) Diesel exhaust particle toxicity on spermatogenesis in the mouse is aryl hydrocarbon receptor dependent. J Reprod Dev 53(5): 1069-1078

Jafarabadi M (2007) Episodic air pollution is associated with increased DNA fragmentation in human sperm without other changes in semen quality. Hum Reprod 22(12):3263

Jedrychowski W, Bendkowska I, Flak E, Penar A, Jacek R, Kaim I, Spengler JD, Camann D, Perera FP (2004) Estimated risk for altered fetal growth resulting from exposure to fine particles during pregnancy: an epidemiologic prospective cohort study in Poland. Environ Health Perspect 112(14):1398-1402

Kannan S, Misra DP, Dvonch T, Krishnakumar A (2006) Exposures to airborne particulate matter and adverse perinatal outcomes: a biologically plausible mechanistic framework for exploring potential effect modification by nutrition. Environ Health Perspect 114(11): 1636-1642

Kannan S, Misra DP, Dvonch JT, Krishnakumar A (2007) Exposures to airborne particulate matter and adverse perinatal outcomes: a biologically plausible mechanistic framework for exploring potential. Cien Saude Colet 12(6):1591-1602

Kelishadi R, Sharifi-Ghazvini F, Poursafa P, Mehrabian F, Farajian S, Yousefy H, Movahedian M, Sharifi-Ghazvini S (2013) Determinants of hypovitaminosis D in pregnant women and their newborns in a sunny region. Int J Endocrinol 2013:1-6

Kim DH, Sabour S, Sagar UN, Adams S, Whellan DJ (2008) Prevalence of hypovitaminosis D in cardiovascular diseases (from the National Health and Nutrition Examination Survey 2001 to 2004). Am J Cardiol 102:1540-1544

Knottnerus JA, Delgado LR, Knipschild PG, Essed GG, Smits F (1990) Haematologic parameters and pregnancy outcome: a prospective cohortstudy in the third trimester. J Clin Epidemiol 43:461-466

Kok TM, Driece HA, Hogervorst JG, Briedé JJ (2006) Toxicological assessment of ambient and traffic-related particulate matter: a review of recent studies. Mutat Res 613(2-3):103-122

Kristensen P, Eilertsen E, Einarsdóttir E, Haugen A, Skaug V, Ovrebø S (1995) Fertility in mice after prenatal exposure to benzo[a]pyrene and inorganic lead. Environ Health Perspect 103(6):588-590

Lange NE, Litonjua A, Hawrylowicz CM, Weiss S (2009) Vitamin D, the immune system and asthma. Expert Rev Clin Immunol 5:693-702

Laumbach RJ (2010) Outdoor air pollutants and patient health. Am Fam Physician 81(2): $175-180$

Lee PC, Roberts JM, Catov JM, Talbott EO, Ritz B (2013) First trimester exposure to ambient air pollution, pregnancy complications and adverse birth outcomes in Allegheny County, PA. Matern Child Health J 17(3):545-555

Leem JH, Kaplan BM, Shim YK, Pohl HR, Gotway CA, Bullard SM, Rogers JF, Smith MM, Tylenda CA (2006) Exposures to air pollutants during pregnancy and preterm delivery. Environ Health Perspect 114(6):905-910

Lewis-Michl EL, Melius JM, Kallenbach LR, Ju CL, Talbot TO, Orr MF, Lauridsen PE (1996) Breast cancer risk and residence near industry or traffic in Nassau and Suffolk Counties, Long Island, New York. Arch Environ Health 51(4):255-265

Li N, Sioutas C, Cho A, Schmitz D, Misra C, Sempf J, Wang M, Oberley T, Froines J, Nel A (2003) U1trafine particulate pollutants induce oxidative stress and mitochondrial damage. Environ Health Perspect 111(4):455-460

Lichtenfels AJ, Gomes JB, Pieri PC, E1 Khouri Miraglia SG, Hallak J, Saldiva PH (2007) Increased levels of air pollution and a decrease in the human and mouse male-to-female ratio in São Paulo, Brazil. Fertil Steril 87(1):230-232

Lloyd OL, Smith G, Lloyd MM et al (1985) Raised mortality from lung cancer and high sex ratios of births associated with industrial pollution. $\mathrm{Br} \mathrm{J}$ Ind Med 42(7):475-480

Logan WP (1953) Mortality in the London fog incident, 1952. Lancet 1:336-338 
Loomis D, Grosse Y, Lauby-Secretan B, El Ghissassi F, Bouvard V, Benbrahim-Tallaa L, Guha N, Baan R, Mattock H, Straif K, on behalf of the International Agency for Research on Cancer Monograph Working Group IARC, Lyon, France, on behalf of the International Agency for Research on Cancer Monograph Working Group IARC, Lyon, France (2013) The carcinogenicity of outdoor air pollution. Lancet Oncol 14(13):1262-1263

Maisonet M, Bush TJ, Correa A, Jaakkola JJ (2001) Relation between ambient air pollution and low birth weight in the Northeastern United States. Environ Health Perspect 109(3):351-356

Maisonet M, Correa A, Misra D, Jaakkola JJ (2004) A review of the literature on the effects of ambient air pollution on fetal growth. Environ Res 95(1):106-115

Mamatsashvili MI (1970) Detrimental effect of carbon monoxide and sulfur dioxide on fertility of female rats. Hyg Sanit 35(4-6):277-279

Mannes T, Jalaludin B, Morgan G, Lincoln D, Sheppeard V, Corbett S (2005) Impact of ambient air pollution on birth weight in Sydney, Australia. Occup Environ Med 62(8):524-530

Marx L, Arck P, Kieslich C, Mitterlechner S, Kapp M, Dietl J (1999) Decidual mast cells might be involved in the onset of human first-trimester abortion. Am J Reprod Immunol 41:34 40

Mattison DR, Thomford PJ (1989) The mechanisms of action of reproductive toxicants. Toxicol Pathol 17(2):364-376

McLachlan JA, Arnold SF (1996) Environmental estrogens. Am Sci 84:452-461

Menzel DB (1994) The toxicity of air pollution in experimental animals and humans: the role of oxidative stress. Toxicol Lett 72(1-3):269-277

Mills NL, Amin N, Robinson SD, Anand A, Davies J, Patel D, de la Fuente JM, Cassee FR, Boon NA, Macnee W, Millar AM, Donaldson K, Newby DE (2006) Do inhaled carbon nanoparticles translocate directly into the circulation in humans? Am J Respir Crit Care Med 173(4):426-431

Miraglia SG, Veras MM, Amato-Lourenço LF, Rodrigues-Silva F, Saldiva PH et al (2013) Follow-up of the air pollution and the human male-to-female ratio analysis in Sao Paulo, Brazil: a times series study. BMJ Open 3(7). pii: e002552. doi:10.1136/bmjopen2013-002552

Mohallem SV, de Araújo Lobo DJ, Pesquero CR, Assunção JV, de Andre PA, Saldiva PH, Dolhnikoff M (2005) Decreased fertility in mice exposed to environmental air pollution in the city of Sao Paulo. Environ Res 98(2): 196-202

Möller W, Felten K, Sommerer K, Scheuch G, Meyer G, Meyer P, Häussinger K, Kreyling WG (2008) Deposition, retention, and translocation of ultrafine particles from the central airways and lung periphery. Am J Respir Crit Care Med 177(4):426-432

Morello-Frosch R, Jesdale BM, Sadd JL, Pastor M (2010) Ambient air pollution exposure and full-term birth weight in California. Environ Health 28(9):44

Need AG, Kemp A, Giles N, Morris HA, Horowitz M, Nordin BE (2002) Relationships between intestinal calcium absorption, serum vitamin metabolites and smoking in postmenopausal women. Osteoporos Int 13:83-88

O'Neill MS, Jerrett M, Kawachi I et al (2003) Health, wealth, and air pollution: advancing theory and methods. Environ Health Perspect 111:1861-1870

Oberdorster G, Utell MJ (2002) Ultrafine particles in the urban air: to the respiratory tract - and beyond? Environ Health Perspect 110:440-441

Olsson D, Mogren I, Forsberg B (2013) Air pollution exposure in early pregnancy and adverse pregnancy outcomes: a register-based cohort study. BMJ Open 3(2):1-8

Ono Y, Takagi K, Seki H, Takai Y, Samejima K, Matsunaga S, Matsumura H (2013) Neonatal outcome in infants of chronically hypertensive mothers. J Obstet Gynaecol Res 39(6): 1142-1146

Osmond C, Barker DJ (2000) Fetal, infant, and childhood growth are predictors of coronary heart disease, diabetes, and hypertension in adult men and women. Environ Health Perspect 108 Suppl 3:545-553

Parent MÉ, Goldberg MS, Crouse DL, Ross NA, Chen H, Valois MF, Liautaud A (2013) Trafficrelated air pollution and prostate cancer risk: a case-control study in Montreal, Canada. Occup Environ Med 70(7):511-518 
Parker JD, Woodruff TJ (2008) Influences of study design and location on the relationship between particulate matter air pollution and birthweight. Paediatr Perinat Epidemiol 22(3):214-227

Pekkanen J, Brunner EJ, Anderson HR, Tiittanen P, Atkinson RW (2000) Daily concentrations of air pollution and plasma fibrinogen in London. Occup Environ Med 57:818-822

Pereira LAA, Loomis D, Conceicao GMS et al (1998) Association between air pollution and intrauterine mortality in Sao Paulo, Brazil. Environ Health Perspect 106:325-329

Perin PM, Maluf M, Czeresnia CE, Januário DA, Saldiva PHN (2010a) Impact of short-term preconceptional exposure to particulate air pollution on treatment outcome in couples undergoing in vitro fertilization and embryo transfer (IVF/ET). J Assist Reprod Genet 27(7):371-382

Perin PM, Maluf M, Czeresnia CE, Nicolosi Foltran Januário DA, Saldiva PHN (2010b) Effects of exposure to high levels of particulate air pollution during the follicular phase of the conception cycle on pregnancy outcome in couples undergoing in vitro fertilization and embryo transfer. Fertil Steril 93(1):301-303

Peters A, Döring A, Wichmann HE, Koenig W (1997) Increased plasma viscosity during an air pollution episode: a link to mortality? Lancet 349(9065):1582-1587

Ponce NA, Hoggatt KJ, Wilhelm M, Ritz B (2005) Preterm birth: the interaction of traffic-related air pollution with economic hardship in Los Angeles neighborhoods. Am J Epidemiol 162(2): 140-148

Pope CA 3rd (2000) Epidemiology of fine particulate air pollution and human health: biologic mechanisms and who's at risk? Environ Health Perspect 108 Supp1 4:713-723

Pope CA 3rd, Ezzati M, Dockery DW (2009) Fine-particulate air pollution and life expectancy in the United States. N Engl J Med 360(4):376-386

Rahman I, MacNee W (2000) Oxidative stress and regulation of glutathione in lung inflammation. Eur Respir J 16(3):534-554

Ren C, Tong S (2008) Health effects of ambient air pollution-recent research development and contemporary methodological challenges. Environ Health 7:56

Reynolds P, Hurley S, Goldberg DE, Anton-Culver H, Bernstein L, Deapen D et al (2004) Regional variations in breast cancer among California teachers. Epidemiol 15(6):746-754

Ritz B, Wilhelm M (2008) Ambient air pollution and adverse birth outcomes: methodologic issues in an emerging field. Basic Clin Pharmacol Toxicol 102(2): 182-190

Ritz B, Yu F, Chapa G, Fruin S (2000) Effect of air pollution on preterm birth among children born in Southern California between 1989 and 1993. Epidemiol 11(5):502-511

Rocha E, Silva IR, Lichtenfels AJ, Amador Pereira LA, Saldiva PH (2008) Effects of ambient levels of air pollution generated by traffic on birth and placental weights in mice. Fertil Steril 90(5): 1921-1924

Rowe T (2006) Fertility and a woman's age. J Reprod Med 51:157-163

Rubes J, Selevan SG, Evenson DP, Zudova D, Vozdova M, Zudova Z, Robbins WA, Perreault SD (2005) Episodic air pollution is associated with increased DNA fragmentation in human sperm without other changes in semen quality. Hum Reprod 20(10):2776-2783

Rudel RA, Attfield KA, Schifano JN et al (2007) Chemicals causing mammary gland tumors in animals signal new directions for epidemiology, chemicals testing, and risk assessment for breast cancer prevention. Cancer 109:2635-2666

Rudra CB, Williams MA, Sheppard L, Koenig JQ, Schiff MA (2011) Ambient carbon monoxide and fine particulate matter in relation to preeclampsia and preterm delivery in western Washington State. Environ Health Perspect 119(6):886-892

Sadeu JC, Hughes CL, Agarwal S, Foster WG (2010) Alcohol, drugs, caffeine, tobacco, and environmental contaminant exposure: reproductive health consequences and clinical implications. Crit Rev Toxicol 40(7):633-652

Saldiva PHN, Clarke RW, Coull BA, Stearns RC, Lawrence J, Krishna Murthy GG, Diaz E, Koutrakis P, Suh H, Tsuda A, Godleski JJ (2002) Lung inflammation induced by concentrated ambient air particles is related to particle composition. Am J Respir Crit Care Med 165:1610-1617

Schnorr TM, Lawson CC, Whelan EA et al (2001) Spontaneous abortion, sex ratio, and paternal occupational exposure to 2,3,7,8-tetrachlorodibenzo-p-dioxin. Environ Health Perspect 109(11):1127-1132 
Schwartz J (2006) Long-term effects of exposure to particulate air pollution. Clin Occup Environ Med 5(4):837-848

Scoriza J, Saldiva PHN, Caldini EG, Veras MM (2009) Effects of pre-gestational and gestational exposure to air pollution (particulate matter) on mast cell density in implantation sites of mice. In: Abstracts of the II symposium on reproductive immunology, Rio de Janeiro, 2009

Seaton A, Macnee W, Donald K, Godden D (1995) Particulate air pollution and acute health effects. Lancet 345:176-178

Selevan SG, Borkovec L, Slott VL, Zudová Z, Rubes J, Evenson DP, Perreault SD (2000) Semen quality and reproductive health of young Czech men exposed to seasonal air pollution. Environ Health Perspect 108(9):887-894

Sioutas C, Delfino R, Singh M (2005) Exposure assessment for atmospheric ultrafine particles (UFPs) and implications for epidemiologic research. Environ Health Perspect 113:947-955

Slama R, Darrow L, Parker J, Woodruff TJ, Strickland M, Nieuwenhuijsen M, Glinianaia S, Hoggatt KJ, Kannan S, Hurley F, Kalinka J, Srám R, Brauer M, Wilhelm M, Heinrich J, Ritz B (2008) Meeting report: atmospheric pollution and human reproduction. Environ Health Perspect 116(6):791-798

Slama R, Bottagisi S, Solansky I, Lepeule J, Giorgis-Allemand L, Sram R (2013) Short-term impact of atmospheric pollution on fecundability. Epidemiology 24(6):871-879

Sokol RZ, Kraft P, Fowler IM, Mamet R, Kim E, Berhane KT (2006) Exposure to environmental ozone alters semen quality. Environ Health Perspect 114(3):360-365

Soll-Johanning H, Bach E (2004) Occupational exposure to air pollution and cancer risk among Danish urban mail carriers. Int Arch Occup Environ Health 77(5):351-356

Somers CM (2011) Ambient air pollution exposure and damage to male gametes: human studies and in situ 'sentinel' animal experiments. Syst Biol Reprod Med 57:63-71

Somers CM, Cooper DN (2009) Air pollution and mutations in the germline: are humans at risk? Hum Genet 125(2): 119-130

Somers CM, Yauk CL, White PA, Parfett CLJ, Quinn JS (2002) Air pollution induces heritable DNA mutations. Proc Natl Acad Sci 99:15904-15907

Somers CM, McCarry BE, Malek F, Quinn JS (2004) Reduction of particulate air pollution lowers the risk of heritable mutations in mice. Science 304:1008-1010

Sørensen M, Daneshvar B, Hansen M, Dragsted LO, Hertel O, Knudsen L, Loft S (2003) Personal PM2.5 exposure and markers of oxidative stress in blood. Environ Health Perspect 111:161-166

Squadrito GL, Cueto R, Dellinger B, Pryor WA (2001) Quinoid redox cycling as a mechanism for sustained free radical generation by inhaled airborne particulate matter. Free Radic Biol Med 31(9): 1132-1138

Srám RJ, Binková B, Dejmek J, Bobak M (2005) Ambient air pollution and pregnancy outcomes: a review of the literature. Environ Health Perspect 113(4):375-382

Sriramachari S (2005) Bhopal gas tragedy: scientific challenges and lessons for future. J Loss Prev Process Ind 18(4-6):264-267

Stillerman KP, Mattison DR, Giudice LC, Woodruff TJ (2008) Environmental exposures and adverse pregnancy outcomes: a review of the science. Reprod Sci 15(7):631-650

Takeda K, Tsukue N, Yoshida S (2004) Endocrine-disrupting activity of chemicals in diesel exhaust and diesel exhaust particles. Environ Sci 11(1):33-45

Takenaka S, Dornhofer-Takenaka H, Muhle H (1986) Alveolar distribution of fly ash and of titanium dioxide after long-term inhalation by Wistar rats. J Aerosol Sci 17:361-364

Telisman S, Colak B, Pizent A, Jurasović J, Cvitković P (2007) Reproductive toxicity of low-level lead exposure in men. Environ Res 105(2):256-266

Terrell ML, Hartnett KP, Marcus M (2011) Can environmental or occupational hazards alter the sex ratio at birth? A systematic review. Emerg Health Threats J 4:1-18

Thurston GD, Balmes JR (2012) Particulate matter and the environmental protection agency setting the right standard. Am J Respir Cell Mol Biol 47(6):727-728

Tragaki A, Lasaridi K (2009) Temporal and spatial trends in the sex ratio at birth in Greece, 1960-2006: exploring potential environmental factors. Popul Environ 30(3): 114-128 
Tsukue N, Toda N, Tsubone H, Sagai M, Jin WZ, Watanabe G, Taya K, Birumachi J, Suzuki AK (2001) Diesel exhaust (DE) affects the regulation of testicular function in male Fischer 344 rats. J Toxicol Environ Health A 63(2):115-126

Vahlsing C, Smith KR (2012) Global review of national ambient air quality standards for PM10 and SO2 (24 h). Air Qual Atmos Health 5:393-399

Valavanidis A, Fiotakis K, Vlachogianni T (2008) Airborne particulate matter and human health: toxicological assessment and importance of size and composition of particles for oxidative damage and carcinogenic mechanisms. J Environ Sci Health C Environ Carcinog Ecotoxicol Rev 26(4):339-362

van den Hooven EH, Pierik FH, de Kluizenaar Y, Willemsen SP, Hofman A, van Ratingen SW, Zandveld PY, Mackenbach JP, Steegers EA, Miedema HM, Jaddoe VW (2012a) Air pollution exposure during pregnancy, ultrasound measures of fetal growth, and adverse birth outcomes: a prospective cohort study. Environ Health Perspect 120(1):150-156

van den Hooven EH, Pierik FH, Kluizenaar Y, Hofman A, van Ratingen SW, Zandveld PY, Russcher H, Lindemans J, Miedema HM, Steegers EA, Jaddoe VW (2012b) Air pollution exposure and markers of placental growth and function: the generation R study. Environ Health Perspect 120(12):1753-1759

Van Erp AM, O'Keefe R, Cohen AJ, Warren J (2008) Evaluating the effectiveness of air quality interventions. J Toxicol Environ Health A 71:583-587

Veras MM, Damaceno-Rodrigues NR, Caldini EG, Maciel Ribeiro AA, Mayhew TM, Saldiva PH, Dolhnikoff M (2008) Particulate urban air pollution affects the functional morphology of mouse placenta. Biol Reprod 79:578-584

Veras MM, Damaceno-Rodrigues NR, Guimarães Silva RM, Scoriza JN, Saldiva PH, Caldini EG, Dolhnikoff M (2009) Chronic exposure to fine particulate matter emitted by traffic affects reproductive and fetal outcomes in mice. Environ Res 109(5):536-543

Veras MM, Guimarães-Silva RM, Caldini EG, Saldiva PH, Dolhnikoff M, Mayhew TM (2012) The effects of particulate ambient air pollution on the murine umbilical cord and its vessels: a quantitative morphological and immunohistochemical study. Reprod Toxicol 34(4):598-606

Vorherr H (1982) Factors influencing fetal growth. Am J Obstet Gynecol 142:577-588

Vrijheid M, Martinez D, Manzanares S, Dadvand P, Schembari A, Rankin J, Nieuwenhuijsen MJ (2011) Ambient air pollution and risk of congenital anomalies: a systematic review. Environ Health Perspect 119:598-606

Wang X, Ding H, Ryan L, Xu X (1997) Association between air pollution and low birth weight: a community-based study. Environ Health Perspect 105(5):514-520

Wenger D, Gerecke AC, Heeb NV, Schmid P, Hueglin C, Naegeli H, Zenobi R (2009) In vitro estrogenicity of ambient particulate matter: contribution of hydroxylated polycyclic aromatic hydrocarbons. J Appl Toxicol 29(3):223-232

WHO (2005) Air quality guidelines - global update 2005. http://www.euro.who.int/_data/assets/ pdf_file/0005/78638/E90038.pdf. Accessed 10 July 2013

Wiebert P, Sanchez-Crespo A, Falk R, Philipson K, Lundin A, Larsson S, Möller W, Kreyling WG, Svartengren M (2006a) No significant translocation of inhaled 35-nm carbon particles to the circulation in humans. Inhal Toxicol 18(10): 741-747

Wiebert P, Sanchez-Crespo A, Seitz J, Falk R, Philipson K, Kreyling WG, Möller W, Sommerer K, Larsson S, Svartengren M (2006b) Negligible clearance of ultrafine particles retained in healthy and affected human lungs. Eur Respir J 28(2):286-290

Wilhelm M, Ritz B (2003) Residential proximity to traffic and adverse birth outcomes in Los Angeles county, California, 1994-1996. Environ Health Perspect 111(2):207-216

Williams FL, Lawson AB, Lloyd OL (1992) Low sex ratios of births in areas at risk from air pollution from incinerators, as shown by geographical analysis and 3-dimensional mapping. Int $\mathrm{J}$ Epidemiol 21(2):311-319

Woodruff TK, Walker CL (2008) Fetal and early postnatal environmental exposures and reproductive health effects in the female. Fertil Steril 89:47-51 
Woodruff TJ, Parker JD, Kyle AD, Schoendorf KC (2003) Disparities in exposure to air pollution during pregnancy. Environ Health Perspect 111(7):942-946

Woodruff TJ, Carlson A, Schwartz JM, Giudice LC (2008) Proceedings of the summit on environmental challenges to reproductive health and fertility: executive summary. Fertil Steril $89(2$ Suppl):e1-e20

World Bank (2013a) Fertility rate (total births per women). http://data.worldbank.org/indicator/ SP.DYN.TFRT.IN. Accessed 15 July 2013.

World Bank (2013b) PM10, country level (micrograms per cubic meter). http://data.worldbank. org/indicator/EN.ATM.PM10.MC.M3. Accessed 15 July 2013.

Wu J, Ren C, Delfino RJ, Chung J, Wilhelm M, Ritz B (2009) Association between local trafficgenerated air pollution and preeclampsia and preterm delivery in the south coast air basin of California. Environ Health Perspect 117(11): 1773-1779

Yang CY, Chang CC, Chuang HY, Ho CK, Wu TN, Tsai SS (2003) Evidence for increased risks of preterm delivery in a population residing near a freeway in Taiwan. Arch Environ Health 58(10):649-654

Yauk CL, Polyzos A, Rowan-Carroll A, Somers CM, Godschalk RW, Van Schooten FJ et al (2008) Germ-line mutations, DNA damage, and global hypermethylation in mice exposed to particulate air pollution in an urban/industrial location. Proc Natl Acad Sci 105:605-610 
4.4.2. Capítulo de livro para a Coleção Sofia Belas Artes: Encontro de Saberes

Neste capítulo ${ }^{(25)}$ utilizei evidências científicas da literatura sobre as relações entre a cidade e qualidade de vida para construir uma narrativa para o público instruído em outras áreas do saber. Publicado em 2015, textos de cientistas e especialistas em artes, arquitetura, ciências sociais e ciências humanas também compõe o livro. A seguir apresento na íntegra o capítulo que escrevi juntamente com meu orientador. 



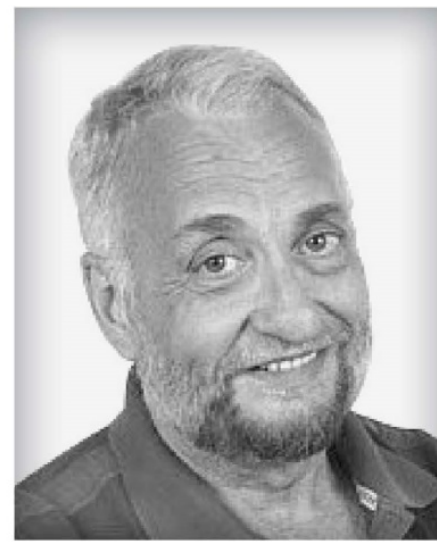

\section{Paulo Saldiva}

Paulo Hilário Nascimento Saldiva - Formado pela Faculdade de Medicina da Universidade de São Paulo em 1977, doutorado em 1983, Livre-Docente em 1986 e Professor Titular do Departamento de Patologia da Faculdade de Medicina da Universidade de São Paulo em 1996. Concentra atividades de Pesquisa nas áreas de Anatomia Patológica, Fisiopatologia Pulmonar, Doenças Respiratórias e Saúde Ambiental e Ecologia Aplicada. Ciclista e gaitista.

\section{Contato}

pepino@usp.br

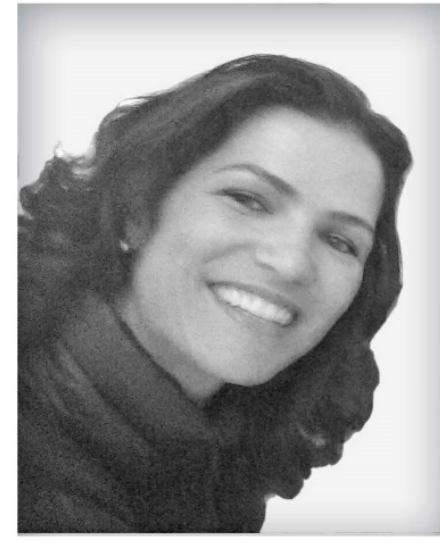

\section{Laís Fajersztajn}

É pesquisadora de doutorado na Faculdade de Medicina da Universidade de São Paulo. Graduada em fisioterapia, com especialização em Reabilitação Gerontológica, trabalhou com Organizações Não Governamentais na área de saúde e sustentabilidade. Sua área de pesquisa inclui poluição do ar, saúde global, cidades saudáveis e sustentabilidade.

\section{Contato}

laisfajer@gmail.com 

por impactos nocivos à saúde, tais como a exposição à poluição do ar, em certa medida estimados no cálculo, mas também pela contribuição desse fator para a obesidade, estresse emocional e outros agravos.

Ademais, o progresso que resultou na vantagem para a saúde de viver nas cidades não atingiu todos os moradores urbanos. Ainda hoje, populações de baixa renda, particularmente aquelas residentes em favelas, convivem com a falta de saneamento básico, tendo dificuldade de acesso aos serviços de saúde. Riscos característicos do passado, como diarreia e infecção por leptospirose, ainda são mais frequentes nessa parcela da população. Soma-se a isso, a influência negativa de determinantes sociais - escolaridade, renda e outros - nos desfechos de saúde desta parcela da população.

Por fim, a violência urbana diminui o desempenho de saúde da população como um todo, seja causando diretamente mortes e incapacidades, seja prejudicando a saúde mental ou restringindo a mobilidade e o lazer dentro da cidade.

Durante as décadas passadas, a Organização Mundial da Saúde tem tentado fortalecer as relaçôes entre saúde e planejamento urbanos através de dois movimentos, ainda pouco robustos na América Latina: Saúde em todas as políticas (Health in all policies) e Movimento das cidades saudáveis (Healthy citiesmovement). Em paralelo, a preocupação da comunidade de saúde com os impactos das mudanças climáticas tem crescido, sendo outra abordagem possivel para fortalecer a comunicação entre ambiente construído e indicadores de saúde. Em 2009, uma série de artigos publicados no The Lancet indicaram que algumas ações que reduzem a emissões de gases de efeito estufa trazem benefícios para a saúde da população local onde tais medidas foram adotadas. Em 2015, a mesma revista alertou: combater as mudanças climáticas pode ser a melhor oportunidade de saúde do século XXI. No artigo, a revista recomendou a transição para cidades que promovam estilos de vida saudáveis para as pessoas e para o planeta, dentre as resposta para mitigar as mudanças climáticas (Watts et al., 2015). Como as populações de baixa renda são mais vulneráveis aos impactos das mudanças climáticas em todas as escalas (entre naçôes e entre cidades), combater as mudanças climáticas pode também ser uma oportunidade para reduzir as desigualdades de saúde.

O desafio de moldar cidades que promovam a saúde de seus moradores é complexo e requer esforço multidisciplinar para além das competências tradicionais do setor de saúde no Brasil. Nos Estados Unidos, um experi- 
mento conduzido pela universidade de Harvard com 4.600 famílias, mostrou que prover auxílio moradia para que famílias de baixa renda se mudem para bairros melhores melhora significativamente a saúde física e mental de crianças e adultos. Além de indicar que os bairros modulam de forma diferente a saúde de seus moradores, o estudo aponta uma possível estratégia de promoção da saúde pública a cargo de outras esferas de governo, que não o setor saúde (Chetty et al., 2015). No mesmo direcionamento, os níveis de poluentes atmosféricos caíram acentuadamente em Dublin após o banimento do uso do carvão na cidade, resultando em redução significativa da mortalidade por causas cardiovasculares e respiratórias em apenas três anos (em 10\% e 16\% respectivamente)(Clancy et al., 2002).

Habitação e mobilidade são diretrizes fundamentais do planejamento urbano que modulam grande parte das associaçôes conhecidas entre ambiente construído e saúde. Neste artigo discutimos alguns dos impactos da mobilidade e da habitação na saúde da população urbana, além dos impactos de outras estruturas urbanas.

O custo anual da imobilidade na cidade de São Paulo equivale a 7,5\% do produto interno Bruto da cidade (Cintra, 2014), com impactos significativos sobre a saúde humana. Os mais estudados são os relacionados à poluição do ar (local e emissão de gases de efeito estufa), tempo de deslocamento, ocorrência de acidentes e realização de atividade física. A imobilidade ainda influencia a saúde mental, por motivos relacionados à segurança pública e à interação social, dentre outros.

Os veículos automotores são os principais responsáveis pelos altos índices de poluição do ar na cidade de São Paulo, que chega a reduzir em cerca de três anos a expectativa de vida média do paulistano. Atualmente, melhorias na qualidade do ar advindas dos avanços tecnológicos na engenharia dos veículos e combustíveis tem sido suplementadas pelo aumento da frota e diminuição na velocidade dos veículos.

A poluição do ar tem efeitos agudos e crônicos reconhecidos. Além do desconforto geral (ardor nos olhos, alergias e etc.), a exposição de curto período a altos níveis de poluentes atmosféricos aumenta a internação hospitalar por doenças cardiovasculares e respiratórias. Entre 1996 e 2000, o aumento foi estimado em cerca de $4 \%$ para crianças com asma e para adultos com doença pulmonar obstrutiva crônica (Gouveia et al,, 2006). A exposição prolongada à polu ição do ar aumenta o risco de câncer pulmão e de morrer por causas cardiovasculares e respiratórias. Baixo nível socioeconô- 
mico e faixa etária (idosos, crianças e mesmo fetos) representam maior vulnerabilidade, bem como o ser portador de doença crônica ou estar grávida. A exposição à poluição do ar está associada com hipertensão gestacional, baixo peso ao nascer, e prematuridade. Os sistemas endócrino e neurológico, dentre outros, também são negativamente afetados pela poluição do ar. Quando se considera a prevalência do fator de risco na população, a poluição do ar e o tráfego de veículos lideram os fatores de risco para infarto do miocárdio. Isso porque, independente da magnitude do risco individual, toda população urbana está de certa forma exposta à poluição do ar e congestionamentos de veículos (Nawrott et al., 2011).

O Brasil ainda adota padróes de qualidade do ar estabelecidos nos anos 90 , que refletem o conhecimento científico dos anos 80 . Na prática, níveis de poluição considerados prejudiciais para a saúde de europeus são considerados seguros pelas autoridades brasileiras. Embora sem data para implementação, o estado de São Paulo se comprometeu a adotar os padrões de qualidade do ar recomendados pela Organização Mundial de Saúde. Políticas de controle da emissão de poluentes veiculares, como as relacionadas no PROCONVE (Programa de Controle da Poluição por Veículos Automotores) tem papel decisivo na melhoria dos níveis de poluição do ar urbano. Por diminuírem o número de carros privados nas ruas, políticas de promoção do transporte público e ativo (andar a pé ou de bicicleta) também melhoram a qualidade do ar.

Os acidentes nas vias da cidade de São Paulo resultaram em 1.249 mortes em 2014, 32,5\% eram motociclistas. O impacto na morbidade é ainda maior, embora seja mais dificil de ser estimado, por causa da falta de dados. A qualidade das calçadas também está associada a acidentes e incapacidades, e influencia o nível geral de atividade física da população, em especial de idosos e portadores de mobilidade reduzida.

A mobilidade nas cidades influencia como as pessoas utilizam seu tempo.As horasperdidas nos congestionamentos reduzem o tempo para outras atividades como trabalho, lazer e descanso, implicando em consequências para a economia da cidade e para a saúde da população. Estudos tem mostrado que, quanto mais horas jovens de baixa renda perdem em trânsito, menor o potencial de aumento de sua renda familiar no futuro, reforçando as desigualdades sociais. $\mathrm{O}$ número reduzido de horas dedicadas ao estudo explica parte do efeito. Ainda, o aumento do tempo de deslocamento tende a aumentar o número de motoristas que infringem a lei e usam dispositivos móveis durante o percurso, aumentando o risco de acidentes. 
O tipo de mobilidade oferecida por uma cidade favorece ou não o sedentarismo, fator de risco para diversas doenças crônicas e, prevalente em mais de $50 \%$ da população maior de 15 anos do Brasil. Estudos mostraram que o uso mais frequente de transporte ativo estava relacionado com risco reduzido de sobrepeso e com pressão arterial mais baixa (Laverty et al,, 2015). Além disso, a mobilidade influencia a exposição ao ruído, afetando a qualidade da audição, do sono, da interação social, entre outros. A exposição crônica ao ruído do tráfego está relacionada ao ganho de peso (Christensen et al., 2015) e alteraçôes cardiovasculares (Halonen et al., 2015).

Por fim, a mobilidade influencia a interação social e a saúde mental de formas fáceis de serem percebidas, como a cordialidade no trânsito ou o receio de furtos durante longos períodos de imobilidade, mas ainda dificeis de serem mensuradas.

As opções de mobilidade que promovem a saúde humana e ambiental são o transporte público e ativo (andar a pé ou de bicicleta). As características ideais dessas formas de mobilidade incluem: segurança, conforto, acessibilidade (tanto em termos de custo financeiro, quanto no que diz respeito ao acesso das pessoas com mobilidade reduzida) e eficiência ( $\mathrm{em}$ termos de gasto de energia, emissão reduzida de poluentes, tempo e cobertura de todo o território da cidade). O metrô é um exemplo de transporte público que atende a esses requisitos. Além da eficiência no tempo de deslocamento, o metrô contribui para a redução da poluição do ar e consequentes custos com internaçôes hospitalares. Análise custo-benefício do metrô de São Paulo mostrou que os ganhos ambientais e sociais superam os gastos elevados de construção e operação (da Silva et al., 2012).

Uma revisão sistemática recente mostrou que os benefícios para a saúde do transporte ativo superam eventuais riscos por conta da exposição aumentada a acidentes de trânsito e à poluição do ar (Muller et al., 2015). A melhoria da qualidade das calçadas e faixas exclusivas para bicicletas são exemplos de como estimular o transporte ativo.

Em relação à habitação, grande parte das melhorias nas condições gerais de saúde da população urbana teve início dentro das residências, a partir de medidas de saneamento e higiene.

Embora considerados direitos humanos básicos pela Organização das Nações Unidas, o acesso à água potável e ao saneamento não atingiu todos os residentes de cidades, principalmente os residentes de favelas, hoje mais de 11 milhões no Brasil. Como resultado, essas pessoas ainda 
convivem com surtos frequentes de doenças infecciosas e mortalidade infantil aumentada, apesar de já existirem meios técnico-cientificos disseminados para a redução desse risco. Outras doenças correlatas incluem doenças por vetores (dengue, por exemplo), doenças tropicais negligenciadas (como a esquistossomose) e doenças relacionas a contaminantes químicos presentes na água.

No Brasil, $94 \%$ da população tem acesso à água potável. No entanto, a taxa de tratamento do esgoto do estado de São Paulo ainda é de 53,34\%, possivelmente porque investimentos em oferta de água potável são percebidos como prioritários comparados à coleta e tratamento de esgoto, tanto pela população quanto pelos governantes.

Apesar dos avanços, a questão do fornecimento de água para as cidades está longe de ser resolvida. Estima-se que os períodos de falta de água nas cidades se tornem mais frequentes com as mudanças climáticas. Em 2015, o nível dos reservatórios de água de São Paulo caiu drasticamente. O período coincidiu com uma epidemia severa de dengue. As mudanças no fornecimento de água e o aumento do armazenamento inadequado de água da chuva podem ter contribuído para o aumento nos casos de dengue em 2015. O armazenamento inadequado de água também impóe riscos para a reincidência de surtos de doenças infecciosas por veiculação hídrica.

Habitações com condições precárias, combinadas à frequente ausência de sistemas de drenagem de água da chuva, aumentam o risco de doenças de veiculação hídrica advindo com as enchentes, como a leptospirose. Muitas regiôes urbanas, como o Jardim Pantanal, na zona leste de São Paulo, são sazonalmente acometidas por enchentes. Dependendo da localidade, há também o risco de deslizamentos que, em última instância, levam à morte. Muitas familias acabam permanecendo em residências inundadas com o intuito de proteger seus bens materiais, indicando também prejuízo da saúde emocional dos acometidos por enchentes.

A qualidade do ar dentro das casas é modulada pela ventilação, níveis de poluentes do ambiente externo e produção de poluentes dentro do ambiente. A fonte de poluição interna mais estudada é a queima de combustíveis sólidos para cozinhar e aquecer a residência. Os impactos para a saúde incluem aumento no risco de pneumonia em crianças menores de cinco anos e doença pulmonar obstrutiva crônica, doenças cardiovasculares, catarata e câncer de pulmão em adultos. Felizmente, a maioria das habitaçôes urbanas brasileira possui fogão. 
erna. Politicas de restrição do fumo em ambientes fechados, como jáéfeito para ambientes de uso coletivo em diversas cidades do Brasil, foram efetivas na redução da exposição. O controle dentro das residências é mais difícil.

Carcinogênico, o amianto foi banido na maioria dos países desenvolvidos. Outros países na América Latina, como Argentina, Chile, Uruguai e Honduras, também baniram a substância. Evitar o uso de materiais com amianto e outros componentes tóxicos, como o formaldeído, é uma recomendação prioritária para melhorar a qualidade do ar dentro das residências.

Melhorias na ventilação e iluminação solar das residências e medidas específicas para garantir o conforto térmico, frente a extremos de temperatura, também melhoram a qualidade do ar interior. Materiais específicos de construção e vegetação tem papel fundamental na manutenção do conforto térmico do ambiente. A saúde respiratória é a grande beneficiada. No entanto, como temperaturas interiores baixas tem sido associadas com maior risco para hipertensão arterial, melhorias do conforto térmico tendem a melhorar também a saúde cardiovascular. Um estudo recente mostrou que a mortalidade por temperaturas extremas varia significativamente de país para país. Além de possível variabilidade da capacidade fisiológica de adaptação a extremos de temperatura das diferentes populações estudadas, o estudo indica que a infraestrutura de alguns países (conforto térmico da habitação, inclusive) é mais preparada para proteger a população frente a extremos de temperatura do que outros. $O$ frio foi responsável pela maioria das mortes prematuras das populações estudadas, $7,29 \%$ (2,38\% no Brasil), contra $0,42 \%$ por calor extremo ( $0,70 \%$ no Brasil) (Gasparini et al., 2015).

Embora o presente artigo tenha abordado a influência da mobilidade e habitação na saúde da população urbana, as áreas se inter-relacionam. O local onde as pessoas moram, por exemplo, influi no modo e tempo de deslocamento. Além disso, outras características urbanas moldam significativamente a saúde nas cidades. A presença de parques é um exemplo. Parques estão associados a um aumento no nível de atividade física, o que impacta positivamente a obesidade e outras doenças crônicas. Um estudo conduzido nos estados Unidos entre 1993 e 1996 mostrou que crianças com acesso facilitado a parques e programas de recreação apresentavam menores índices de obesidade (Wolch, et al., 2014). Também nos Estados Unidos, um estudo mostrou que comunidades de baixa renda tem acesso restrito a parques, e que os parques costumam ser mais 
poluídos em áreas de baixa renda. Não é difícil de imaginar que a situação no Brasil seja semelhante. Ademais, parques são um meio de aumentar a cobertura verde da cidade, o que ajuda a drenar as águas da chuva, prevenindo enchentes, bem como ajudam a mitigar o efeito das ilhas urbanas de calor. "Ilhas urbanas de calor" é a terminologia que caracteriza o aumento de temperatura de áreas urbanas comparado à temperatura prévia na mesma região em anos anteriores ou em regiốes do entorno durante o mesmo período. Em São Paulo, a diferença de temperatura entre a zona central e periférica da cidade pode atingir $10^{\circ} \mathrm{C}$.

As ilhas urbanas de calor favorecem a formação de um poluente em particular, o ozônio troposférico. Formado na presença de luz, a partir de nitrogênio e compostos orgânicos voláteis liberados pela queima de combustiveis fósseis, o ozônio é fortemente relacionado a crises agudas de asma e alteraçôes cardiovasculares. Entre 1990 e 2013, a mortalidade ajustada por ozônio no mundo aumentou em quase 20\% (Forouzanfar et al., 2013).

No verão, a diferença de temperatura entre o centro (quente) e a periferia (menos quente) da cidade aumenta eventos de chuva forte nas partes centrais da cidade, favorecendo enchentes e seus malefícios à saúde. As enchentes, em conjunto com o prejuízo no funcionamento dos semáforos, agravam a imobilidade na cidade.

As ilhas urbanas de calor aumentam os períodos prolongados de temperatura muito elevada, eventos conhecidos como ondas de calor. Fortemente associadas com aumento da mortalidade, as ondas de calor favorecem a concentração de poluentes atmosféricos, aumentando a incidência de doenças relacionadas à poluição já descritas neste artigo. Estima-se que a temperatura média no Brasil possa subir entre $2^{\circ} \mathrm{C}$ e $4^{\circ} \mathrm{C}$ até 2100 (Marengo et al., 2009), mas, ao contrário de países desenvolvidos como a Austrália, o Brasil não dispõe de políticas consistentes para proteger sua população dos extremos de temperatura.

$\mathrm{O}$ aumento da temperatura do ar ainda influencia a distribuição de doenças causadas por vetores como a dengue. A taxa de incidência da dengue na cidade de São Paulo (casos por 100.000 habitantes) em 2010-2011 foi maior em áreas que combinavam cobertura vegetal restrita e altas temperaturas médias de superfície do que em áreas com ampla cobertura vegetal: 72,3 casos contra 3,2 casos. A alta temperatura $(>320 \mathrm{C})$ foi o principal determinante para a concentração dos casos, superando características socioeconômicas como regiôes de baixo nível socioeconômico, moradia precária e alta densidade populacional (Araujo et al., 2015). 
dos grandes centros urbanos tende a aumentar a frequência e intensidade de ondas de calor, períodos de seca e de chuva intensa. $\mathrm{O}$ aumento de áreas verdes nos centros urbanos pode resfriar a temperatura do local e do entorno, contribuindo para a mitigação das ilhas urbanas de calor. $\mathrm{O}$ uso de matérias com maior potencial reflexivo na superfície de construções também pode auxiliar.

A distribuição dos serviços na cidade também influencia a saúde dos moradores. Um estudo mostrou que crianças que moram em bairros com menos lojas de conveniência e supermercados apresentam menor indice de obesidade. (Shier et al., 2012)

Ademais, as desordens psiquiátricas são mais prevalentes em áreas urbanas que rurais e contribuem para cerca de um quarto da sobrecarga total da doença na América Latina e Caribe. Condições prevalentes em muitas cidades com grande desvantagem socioeconômica, baixo nível de atividade física, baixo nível de interação social e altos índices de violência, podem resultar em doença mental.

Promover mudanças urbanísticas efetivas para uma cidade mais saudável requer a interação multidisciplinar entre diversas pastas do governo, sociedade civil e outros atores da sociedade. Apesar da magnitude do desafio, os beneficios parecem fortes o suficiente para consensos efetivos, afinal, uma cidade que promova a saúde de sua população é interesse de todos. Ademais, uma cidade saudável deveria ser interesse particular dos profissionais de saúde, pois representa um grande auxílio terapêutico no enfrentamento de doenças e promoção da qualidade de vida.

\section{Referências}

ARAUJO, R.V., ALBERTINI, M.R., COSTA-DA-SILVA, A.L., et al. Säo Poulo urban heat islonds have a higher incidence of dengue than other urban areas. (2015) Braz J Infect Dis. 19(2):146-55. CHETTY, R., HENDREN, N., Katz, L. The Effects of Exposure To Better Neighborhoods on Children: New Evidence from The Moving to Opportunity Experiment (2015). Working Paper 21156. Harvard University.

CHRISTENSEN, J.S., RAASCHOU-NIELSEN, O., TJØNNELAND, A., NORDSBORG, R.B., JENSEN, S.S., SØRENSEN, T.I., SØRENSEN, M. Long-term exposure to residential traffic noise and changes in body weight and woist circumference: A cohort study.(2015). Environ Res.19;143 (Pt A): 154-161.

CINTRA, M. Os custos dos congestionomentos na cidode de Sö́ Paulo. (2014). Textos para Discussão da Escola de Economia de São Paulo da Fundação Getulio Vargas FGV-EESP.

CLANCY, L., GOODMAN, P., SINCLAIR H., DOCKERY, D.W. Effect of air-pollution control 
on deoth rotes in Dublin, frelond: on intervention study. (2002). Lancet.19;360(9341):1210-4 SILVA, C.B.P. da, SALDIVA, P.H.N., AMATO-LOURENÇO, L.F., RODRIGUES-SILVA, F., Miraglia, S.G.E. Evaluation of the air quality benefits of the subway system in Säo Paulo, Brozil. (2012). Journal of Environmental Management. 101: 191-196.

FOROUZANFAR, M.H., ALEXANDER, L., ANDERSON, H.R, et al. Global, regional, and national comparative risk assessmentof 79 behovioural, environmental and occupational, and metabolic risks or clusters of risks in 188 countries, 1990-2013: a systematic analysis for the Global Burden of Disease Study 2013. (2015). Lancet. Published online: http://dx.doi. org/10.1016/S0140-6736(15)00128-2.

GASPARRINI A, GUO Y, HASHIZUME M, et al.. Mortolity risk attributable to high and low ambient temperature: a multicountry observational study. Lancet. 2015 pii: S01406736(14)62114-0. doi: 10.1016/\$0140-6736(14)62114-0.

GOUVEIA, N., FREITAS, C.U.M., CONCEIÇÃO, L. Marcilio, I.O. Hospitalizaçōes por cousas respiratórios e cardiovasculares associados à contaminaçäo atmosférica no Municipio de Säo Poulo, Brosil pollution in the city of São Paulo, Brazil. (2006). Cadernos de Saúde Pública. 22 (12), 2669-77.

HALONEN, J.I., HANSELL, A.L., GULLIVER, J., MORLEY, D., BLANGIARDO, M., FECHT, D., TOLEDANO, M.B., BEEVERS, S.D., ANDERSON, H.R., KELLY, F.J., TONNE, C. Rood troffic noise is associated with increased cardiovascular morbidity and mortolity and all-cause mortality in London. (2015) Eur Heart J. 14;36(39):2653-61.

LAVERTY AA, PALLADINO R, LEE JTS, MILLETT C. Associotions between octive trovel and weight, blood pressure and diabetes in six middle income countries: a cross-sectional study in older odults. Int J Behav Nutr Phys Act. 2015 May 20;12:65.

MARENGO, J. A., JONES, R., Alves, L. M., VALVERDE, M. (2009). Future change of temperature and precipitation extremes in South Americo as derived from the PRECIS regional climate modeling system. International journal of Climatology. 29 (15): 2241-2255. MUELLER, N., ROJAS-RUEDA, D., COLE-HUNTER, T., et al. Health impact assessment of active transportation: A systematic review. (2015). Prev Med. 18 (6), 103-114.

NAWROT, T.S., PEREZ, L., KÜNZLI, N., MUNTERS, E., NEMERY, B. Public health importance of triggers of myocardial infarction: a comparative risk assessment. (2011). Lancet. 26;377(9767):732-40. doi: 10.1016/S0140-6736(10)62296-9.

SHIER, V., An, R., STURM, R. is there a robust relotionship between neighbourhood food environment and childhood obesity in the USA? (2012). Public Health. 126(9):723-30.

WATTS, N., ADGER, W. N., AGNOLUCCI, P., BLACKSTOCK, J., BYASS. P., et al. (2015). Health and climate change: policy responses to protect public heolth. (2015). Lancet, Published Online, 22 June 2015.

WOLCH, J.R., BYRNE, J., NEWELL, J.P. (2014). Urban green space, public health, and environmentol justice: The challenge of making cities 'just green enough': Landscope and Urban Planning. 125, 234-244. 
4. 4.3. Artigo na revista do Instituto de Estudos Avançados

$\grave{A}$ exemplo do manuscrito descrito no item anterior, neste $\operatorname{artigo~}^{(10)}$, o tema abordado também foi cidades e qualidade de vida. No entanto utilizei evidências científicas da literatura para construir uma narrativa introdutória do assunto para um dossiê sobre metrópoles e saúde publicado em 2016. O dossiê conta com textos de outros autores específicos para habitação, poluição do ar, assistência à saúde e áreas verdes, além de abordagens do ponto de vista das ciências humanas. A revista é uma das mais acessadas da plataforma de busca Scielo e é lida por gestores e demais interessados em políticas públicas. A seguir apresento o artigo na íntegra. 


\title{
Como as cidades podem favorecer ou dificultar a promoção da saúde de seus moradores?
}

\author{
LAÍS FAJERSZTAJN I', MARIANA VERAS ${ }^{I I}$ \\ - PAULO HILÁRIO NASCIMENTO SALDIVA ${ }^{I I}$
}

\section{Introdução}

$\mathrm{M}$ AIS DA METADE da população mundial vive em cidades. Na América Latina - o continente mais urbanizado do mundo -, a população urbana chega a $82 \%$; no Brasil, a $84 \%$. Com tantas pessoas morando em cidades, entender a influência do ambiente construído na saúde das pessoas torna-se assunto prioritário.

Por muitos séculos, o estilo de vida das cidades causou piores condições de saúde, como maior risco para cólera, diarreia, tuberculose e outras doenças infecciosas. A densidade populacional favorecia a emergência de epidemias, e viver em cidades representava uma desvantagem para a saúde em comparação à vida no campo. Com o desenvolvimento científico sobre as formas de transmissão de doenças, iniciado no século XIX, as cidades começaram a se estruturar visando à promoção da saúde pública, principalmente a partir da adoção de medidas sanitárias. Os serviços de assistência à saúde acompanharam o desenvolvimento científico-tecnológico de forma muito mais eficiente nos centros urbanos e o viver nas cidades passou a ser uma vantagem para a saúde, quando comparado com a vida rural.

Hoje doenças diretamente relacionadas à forma como a sociedade está organizada c ao estilo de vida urbano, como hipertensão arterial, diabetes tipo $2 \mathrm{c}$ obesidade, predominam nas cidades. Conhecidas como Doenças e Agravos Não Transmissíveis (Dant), essas doenças foram responsáveis por $76 \%$ da mortalidade geral, $63 \%$ das internações pagas e $73 \%$ dos gastos do Sistema Único de Saúde (SUS) com internações no município de São Paulo, segundo dados do site oficial da prefeitura. A estratégia de enfrentamento tem se baseado principalmente na modificação de fatores de risco individuais, com resultados positivos, porém limitados, visto que o ambiente urbano pode facilitar ou dificultar hábitos individuais saudáveis, como a prática de atividade física ou a ingestão de frutas $\mathrm{e}$ vegetais. Sendo assim, a integração de políticas de promoção da saúde coletiva
\end{abstract}


e de urbanismo resultaria em ganhos de saúde significativos para os moradores de cidades.

Alguns exemplos bem-sucedidos de controle e prevenção de doenças a partir da modificação de fatores de risco individuais incluem o controle medicamentoso da pressão arterial e colesterol, parar de fumar, alimentar-se de forma mais saudável e praticar atividade física. A lei antifumo, que proibiu fumar em ambientes fechados de uso coletivo no estado de São Paulo em 2009, diminuiu a exposição dos não fumantes à fumaça do tabaco. Tal lei ainda resultou na diminuição da quantidade de cigarros/dia entre os fumantes, sendo um exemplo concreto de como o funcionamento de uma cidade pode melhorar a saúde de sua população. Com custo anual estimado em mais de R $\$ 40$ bilhões, valor equivalente a $1 \%$ do PIB brasileiro (Cintra, 2014), a imobilidade no município de São Paulo é um exemplo oposto. A crise de mobilidade afeta a saúde não só por conta do tempo perdido no congestionamento $\mathrm{c}$ impactos nocivos da exposição à poluição do ar à saúde, em certa medida estimados no cálculo, mas também pela sua contribuição para a obesidade, estresse emocional, entre outros. Numa cidade congestionada, crianças não brincam na rua e adultos não retornam para almoçar em casa, costume prevalente em São Paulo quando a obesidade ainda não era uma epidemia.

Ademais, o progresso que resultou na vantagem para a saúde de viver nas cidades não atingiu todos os moradores de países em desenvolvimento. Ainda hoje, populações urbanas de baixa renda, particularmente residentes de favelas, ainda convivem com a falta de saneamento básico e condições seguras de moradia. Frequentemente essas populações sofrem com enchentes, falta de água, surtos de doenças infecciosas, entre outros riscos para a saúde, cujas formas preventivas são amplamente evitáveis e conhecidas. Além disso, determinantes sociais como escolaridade, moradia, alimentação e renda exercem influência negativa em moradores de favela, prejudicando ainda mais o desempenho em saúde dessa parcela da população. Por fim, a violência urbana diminui o desempenho da saúde de toda a população, seja causando mortes e incapacidades diretamente, seja prejudicando a saúde mental, ou ainda, restringindo a mobilidade e lazer dentro das cidades. A Região Metropolitana de São Paulo (RMSP) lidera a prevalência de desordens mentais no mundo, quase $30 \%$ da população apresentam algum distúrbio como ansiedade e abuso de substâncias, segundo estudo realizado por Andrade et al. (2012). Os pesquisadores mostraram que a exposição à violência (como ter presenciado um assassinato ou ter sido roubado) estava significativamente associada com as desordens mentais e, quanto maior a exposição à violência, a gravidade da doença também tendia a ser maior (Andrade et al., 2012).

Durante as últimas décadas, a Organização Mundial da Saúde (OMS) tem tentado fortalecer as relações entre saúde e planejamento urbano por meio de dois movimentos: Saúde em todas as políticas (Health in all polices) (Ollila, 
2011) e Movimento das cidades saudáveis (Healthy cities movement) (Rydin et al., 2012); no entanto, esses movimentos ainda não são fortes nas cidades latino-americanas.

Recentemente, a preocupação da comunidade de saúde com os impactos das mudanças climáticas tem crescido, sendo outra abordagem possível para fortalecer a comunicação entre ambiente construído e melhor desempenho de indicadores de saúde. Em 2009, uma série de artigos publicados no The Lancet indicou que algumas ações que reduzem as emissões de gases de efeito estufa trazem também benefícios para a saúde da população onde as medidas foram adotadas (Haines et al., 2009). Em 2015, a mesma revista alertou para o fato de que combater as mudanças climáticas pode ser a melhor oportunidade de saúde do século XXI (Dora et al., 2015; Watts et al., 2015). Como as populações de baixa renda são mais vulneráveis aos impactos das mudanças climáticas em todas as escalas (entre nações e entre cidades), combater as mudanças climáticas pode ser uma oportunidade para reduzir as desigualdades de saúde.

O desafio de moldar cidades que promovam a saúde de seus moradores é complexo e requer esforço multidisciplinar para muito além das competências atuais atribuídas ao setor de saúde no Brasil. O experimento "Moving to Oportunity" conduzido pela universidade de Harvard com 4.600 famílias mostrou que prover assistência para que famílias de baixa renda se mudem para bairros mais saudáveis melhorou significativamente a saúde física e mental de crianças e adultos (Chetty et al., 2015).

Neste artigo propomos uma discussão das relações entre o ambiente construído e a saúde coletiva a partir dos cinco tópicos propostos por Rydin et al. (2012): a) transporte, mobilidade e atividade física; b) produção urbana de alimento; c) ilhas urbanas de calor; d) conforto térmico e qualidade do ar de ambientes fechados (indoor); e e) saneamento.

\section{a) Transporte, mobilidade e atividade física}

O custo anual da imobilidade na cidade de São Paulo equivale a 7,5\% do PIB da cidade (Cintra, 2014), com impactos significativos para a saúde dos moradores. Os veículos automotores são os principais responsáveis pelos altos índices de poluição do ar aos quais os paulistanos estão expostos. Estima-se que a poluição do ar em São Paulo reduza em cerca de 3,5 anos a expectativa de vida média desta população.

O meio de transporte utilizado por um indivíduo em seu dia a dia pode ser determinante para sua saúde. De fato, transporte é um dos determinantes sociais da saúde, segundo a Organização Mundial da Saúde (OMS). Além disso, as emissões veiculares que contribuem tanto para a poluição do ar urbano quanto para as alterações no clima global também impactam diretamente de forma negativa a saúde das pessoas (WHO, 2011).

Por isso, tanto o planejamento quanto as políticas públicas de transporte devem considerar a saúde como um dos critérios de avaliação durante a formu- 
lação e mesmo após sua implementação. Na América Latina a inclusão da saúde como um determinante durante esse processo não parece ser uma rotina.

A urbanização latino-americana é caracterizada pela industrialização, pela deterioração ambiental, cidades superpopulosas cercadas por uma periferia pobre, congestionamentos e poucas op̧̧ões eficientes de transporte público. E o transporte individual em veículos automotores é o modo de transporte prevalente. Contribui para essa escolha o fato de "ter um carro" ser sinônimo de mobilidade, conforto e status social (Newman; Kenworthy, 1999).

Olhando sob a perspectiva da saúde, os carros são prejudiciais, pois diminuem a atividade física, contribuem para o isolamento social, causam estresse e a perda de horas de descanso, lazer e trabalho, devido aos congestionamentos. Além disso, colaboram significativamente para a poluição do ar e sonora, e acidentes por automóveis provocam a morte de milhares de pessoas todos os anos (apud McMichael, 1996; Rissel, 2009). A poluição do ar tem efeitos agudos e crônicos reconhecidos. Além do desconforto geral (ardor nos olhos, alergias etc.), a exposição de curto período a altos níveis de poluentes atmosféricos aumenta a internação hospitalar por doenças cardiovasculares e respiratórias (Braga et al., 2002, Saldiva et al., 1992). Entre 1996 e 2000 , o aumento de $10 \mu \mathrm{g} / \mathrm{m}^{3}$ do poluente MP 10 (material particulado menor que 10 micrometros) associou-se com um aumento nas admissões hospitalares de $4,6 \%$ por asma em crianças e $4,3 \%$ por doença pulmonar obstrutiva crônica (Gouveia et al., 2006). A exposição prolongada à poluição do ar aumenta o risco de câncer pulmão (Loomis et al., 2013) e de morte por causas cardiovasculares e respiratórias. Baixo nível socioeconômico e faixa etária (fetos, crianças e idosos) apresentam maior vulnerabilidade, assim como ser portador de doenças crônicas ou estar grávida. A exposição à poluição do ar está associada com hipertensão gestacional, baixo peso ao nascer e prematuridade (Stieb et al., 2012). O sistema endócrino (diabetes e obesidade) e o neurocognitivo, entre outros, também são negativamente afetados pela poluição do ar.

A saúde pode ser impactada diretamente de forma positiva pela escolha do meio de transporte que utilizarmos, prevenindo doenças ligadas ao sedentarismo e, indiretamente, pela diminuição dos efeitos causados ao meio ambiente devido às emissões dos escapamentos. As alternativas de transporte benéficas à saúde incluem caminhar, andar de bicicleta e utilizar o transporte público. Entretanto, para que as pessoas utilizem meios mais ativos de transporte, seria necessário que esses oferecessem conforto, segurança, acessibilidade, baixo custo e, principalmente, que fossem integrados de forma a estimular seu uso.

Um dos maiores desafios dos planejadores urbanos é melhorar o transporte urbano em termos de eficiência no deslocamento e diminuição das emissões veiculares. Uma forma de estimular o uso do transporte ativo é integrar ciclovias ao sistema de transporte público. Isso já é empregado na Europa e em alguns 
países na América Latina, com excelentes resultados na saúde da população e para o meio ambiente (Pucher; Buehler, 2008; 2007; Gomez et al., 2015).

Um revisão sistemática recente sobre benefício do transporte ativo para a saúde mostra claramente que essa opção gera grandes ganhos apesar dos riscos de acidentes e da exposição à poluição do ar. Os benefícios estão ligados ao fato de o transporte ativo proporcionar um aumento na atividade física $e$ interação social, reduzindo os riscos para doenças como diabetes, hipertensão e obesidade (Muller et al., 2015). E essa é uma questão muito importante de saúde pública, pois $30 \%$ dos adultos fazem menos exercício que o recomendado, o que juntamente com uma dieta rica em calorias e gorduras é a principal causa da obesidade.

Na América Latina, ao contrário do que ocorre na Europa e na América do Norte, o apelo para mudanças nas políticas de transporte está relacionado à resolução de problemas de mobilidade (congestionamentos) e os argumentos são praticamente baseados somente em questões econômicas e materiais (Becerra et al., 2013). Os setores da saúde e do do meio ambiente deveriam participar do processo de tomada de decisão sobre mobilidade e os planejadores urbanos deveriam estar conscientes dos impactos que o ambiente construído e dos meios de transporte trazem à saúde física e mental. As iniciativas de estímulo $\mathrm{e}$ implementação de alternativas de transporte ativo ou sua integração ao sistema tradicional na América Latina são poucas. Mas em algumas grandes cidades, como Rio de Janeiro, São Paulo, Curitiba, Bogotá, Buenos Aires e Santiago, já se observam mudanças e a implementação de ciclovias integradas como opção alternativas ao transporte individual. Também há em grandes capitais a implantação dos BRT, que são ônibus de trânsito rápido em vias exclusivas (México, São Paulo, Belo Horizonte, Equador). Essas medidas reduzem o número de veículos na rua e, portanto, os níveis de poluentes tendem a cair, e dessa forma também contribuem para uma melhora na saúde geral da população.

O estudo de Laverty et al. (2015) examinou a correlação entre dados sociais e demográficos e o uso de meios de transporte ativo e desfechos específicos de saúde (diabetes, pressão arterial, sobrepeso) de adultos em seis países (México, Índia, China, Rússia, Gana e África do Sul). Os seus resultados mostraram que os indivíduos que realizam seus deslocamentos de forma mais ativa apresentam riscos reduzidos para ganho de sobrepeso e alterações prejudiciais na pressão arterial.

A poluição do ar é o principal fator de risco ambiental para a saúde e o único meio de evitá-lo é reduzindo seus níveis, ou seja, reduzir as emissões. A OMS estima que 1,3 milhão de mortes por ano estejam associadas a exposição à poluição do ar no mundo. Os impactos sobre a saúde incluem uma grande variedade de efeitos que são influenciados por idade, sexo e presença de doenças preexistentes no indivíduo exposto: doenças cardiorrespiratórias, doenças neurodegenerativas, diminuição da fertilidade e câncer (HEI, 2010; Calderón- 
-Garcidueñas et al., 2008). A frota de veículos também contribui para a emissão de gases do efeito estufa colaborando de forma efetiva para acelerar as mudanças climáticas e seus impactos sobre a saúde. Temperaturas extremas estão associadas a um aumento de risco para mortalidade por diferentes causas (Anderson; Bell, 2009; Analitis et al., 2008). Um estudo recente de nosso grupo de pesquisa mostrou que variações moderadas na temperatura também estão associadas a riscos aumentados para mortalidade reforçando a importância das alterações climáticas (variações térmicas) na saúde (Gasparrini et al., 2015).

$\mathrm{O}$ transporte ativo integrado a um sistema de transporte público eficiente é uma das alternativas para melhorar a saúde humana, reduzir a poluição ambiental e mitigar as mudanças climáticas. O desafio que os planejadores urbanos e formuladores de políticas enfrentam hoje no desenvolvimento de municípios é como implementar isso em um ambiente urbano concebido para favorecer o modo de transporte privado. Em suma, o transporte ativo não é apenas um meio de reduzir a poluição do ar e as mudanças climáticas em médio e longo prazos, mas também uma forma de melhorar a saúde de milhões de pessoas em curto prazo.

\section{b) Produção urbana de alimento}

A produção de alimentos $\mathrm{em}$ ambientes urbanos não é uma novidade (FAO, 2014). Insegurança alimentar devido à pobreza (Zezza; Tasciotti, 2010; Wolch et al., 2014), guerra (Milbourn; Vail, 2010, Rydin et al., 2012) e desastres naturais (Hara et al., 2013) garantiu a produção urbana de alimentos nas últimas décadas, mesmo que em pequena escala. Com apelos fundados na sustentabilidade ambiental, atualmente a UPA (sigla em inglês para agricultura urbana e periurbana) tem ressurgido nas cidades mais sustentáveis dos países desenvolvidos (Midle et al., 2014; Hara et al., 2013; Rydin et al., 2012). Ao invés de substituir as atuais e eficientes formas de produção de alimentos para suprimento das cidades, a proposta da UPA é conviver com as op̧̧ões tradicionais. Segundo relatório da Organização das Nações Unidas para a Alimentação e Agricultura (FAO) de 2014, a UPA está presente em muitas cidades da América Latina, principalmente em quintais residenciais e escolas, mas também de forma comercial. Rosario, uma cidade de 1,35 milhão de habitantes na Argentina, tem 800 hortas comunitárias que produzem verduras para 40 mil pessoas. Cerca de 23 mil hectares de terra são dedicados à plantação na cidade do México, e em Cuba, 40 mil pessoas trabalham em hortas urbanas. Os benefícios da agricultura urbana incluem melhorias ambientais, econômicas, sociais e de saúde.

Comparado com outros residentes urbanos, famílias de agricultores consomem mais frutas e vegetais. A baixa ingestão de frutas e vegetais é um dos dez fatores de risco que mais contribuem para a sobrecarga da doença (Lim et al., 2012). Alimentação de qualidade melhora a saúde cardiovascular (Hu et al., 2011) e ajuda a combater outras doenças crônicas não transmissíveis como obesidade (Gatto et al., 2015) e diabetes (Tohill et al., 2004). A UPA cria oportu- 
nidades para a prática de atividade física e interação social reforçando os ganhos em saúde já descritos (Rydin et al., 2012).

Os serviços ecológicos da agricultura urbana podem incluir a regulação do microclima local, manutenção da fertilidade do solo e regulação da polinização dependendo da forma como é conduzida, entre outros (Swinton et al., 2007). Quando o alimento é produzido localmente, a demanda por transporte é reduzida, resultando em economia de energia e diminuição na emissão de poluentes atmosféricos. Outros ganhos em potencial incluem a redução de exportação de resíduos sólidos, desde que projetos de compostagem para uso na UPA sejam implementados, e melhor manejo da água de chuva. Isso porque a maior prevalência da UPA aumenta a superficie de cobertura verde permeável na cidade, permitindo a recuperação das reservas de água (Angnotti, 2015) e auxiliando a prevenção de inundações durante períodos chuvosos. Vale ressaltar ainda que o aumento da cobertura verde urbana tem sido relacionado a diversos benefícios à saúde mental.

A UPA também tem potenciais ganhos econômicos diretos. Famílias envolvidas com a UPA diminuem seus gastos com comida e geram renda extra com vendas, caso esta não seja a atividade principal da família (FAO, 2014). Revitalização de comunidades de baixa renda (Angnotti, 2015) e aumento no valor dos imóveis da região da UPA pela melhoria estética da região (Rydin et al., 2012) podem emergir como ganhos sociais e econômicos indiretos.

Os desafios técnicos com a qualidade das sementes, solo, entre outros, são frequentes, mas podem ser superados. O Programa Escola Estufa Lucy Montoro de 2009 , que, entre outros, visa estimular a produção de hortaliças e mudas de árvores é um exemplo de apoio da prefeitura de São Paulo para a atividade. Abordagens mais ecológicas de produção podem contribuir para a preservação do meio ambiente como a poluição das águas e para a redução de doenças ocupacionais por exposição a agrotóxicos.

O maior desafio da UPA é o espaço. Entretanto, estratégias urbanísticas, como telhados verdes (Torrenggiani et al., 2012), podem viabilizar a UPA mesmo em cidades altamente populosas.

Por fim, é importante atentar para a alta prevalência de solos contaminados em áreas urbanas. O estudo dos impactos para a saúde de alimentos produzidos em solos contaminados é escasso. Antes de escolher uma área para UPA, é recomendada uma avaliação das condições locais (solo, incidência de luz, oferta de água etc.). A história de ocupação do solo local pode indicar de forma indireta o potencial de contaminação do solo, na ausência de testes de contaminação (padrão de referência). No caso de atividades industriais, postos de gasolina e lavanderias é prudente considerar o solo contaminado. A remediação é frequentemente possível, mas a falta e alto custo de serviços especializados podem ser um impeditivo. Uma alternativa possível é importar solo saudável e plantar em vasos (Rydin et al., 2012; Angnotti, 2015; Kessler, 2013). Para prevenir exposi- 
ções nocivas é prudente seguir recomendações de cultivo como as propostas por Kessler (2013) para agricultores urbanos. As recomendações incluem práticas de agricultura (exemplo: cobrir o solo e as passagens existentes com adubo), bons hábitos (exemplo: usar luvas) e critérios de escolha do local da atividade (exemplo: estabelecer a atividade longe de ruas $\mathrm{e}$ avenidas).

Ante os potenciais benefícios para a saúde ambiental e humana discutidos, a OMS recomendou que políticas alimentares sejam incorporadas no planejamento urbano (Rydin et al., 2012).

\section{c) Ilhas urbanas de calor}

Ilha urbana de calor é a terminologia que caracteriza o aumento de temperatura de áreas urbanas, comparado à temperatura prévia na mesma região em anos anteriores, ou em regiões do entorno durante o mesmo período. Consequência do processo de urbanização, a substituição da cobertura vegetal do solo por prédios, ruas, avenidas e outras construções de infraestrutura absorve a luz solar, irradia calor e retém menos água, comparado a solos com cobertura natural, reduzindo a umidade para evaporação e resfriamento (Berdahl; Bretz, 1997; Sobral, 2005). A redução da cobertura verde, o uso intensivo de combustíveis fósseis e a construção de prédios altos, que atuam como barreiras para a ventilação, podem explicar as ilhas urbanas de calor (Sobral, 2005). No Brasil, um estudo mostrou que a diferença média de temperatura entre o centro e a periferia de uma cidade média (cerca de 1,5 milhão de habitantes) foi de $6{ }^{\circ} \mathrm{C}$ (Santos et al., 2013). Já um estudo conduzido na Região Metropolitana do Rio de Janeiro encontrou variabilidades térmicas de até $25^{\circ} \mathrm{C}$ entre áreas com diferentes níveis de urbanização (Sena et al., 2014). As ilhas urbanas de calor podem agravar os períodos prolongados de temperatura muito elevada, eventos conhecidos como ondas de calor.

$\mathrm{O}$ aumento da temperatura do ar impacta a flora e a fauna, influenciando a disseminação de doenças causadas por vetores como dengue, zika e febre chicungunya (Coelho-Zanotti; Massad, 2012, Laschewski; Jendritzky, 2002). A taxa de incidência de dengue na cidade de São Paulo (casos por 100 mil habitantes) em 2010-2011 foi maior em áreas que combinavam cobertura vegetal restrita e altas temperaturas médias de superfície $\left(29 \pm 2^{\circ} \mathrm{C}\right)$ do que em áreas com ampla cobertura vegetal: 72,3 casos contra 3,2 casos. A alta temperatura $\left(>32^{\circ} \mathrm{C}\right.$ ) foi o principal determinante para a concentração dos casos, superando características sociocconômicas como regiões de baixo nível socioeconômico, moradia precária e alta densidade populacional (Araujo et al., 2015).

Eventos de ondas de calor têm sido associados a aumento da mortalidade. $\mathrm{Na}$ Inglaterra e no País de Gales o calor associou-se a aumento da mortalidade de idosos por quase todas as causas no verão no período de 1993 a 2006 (Gasparrini et al., 2012). Um estudo recente, considerando 384 localidades em 13 países, mostrou que temperaturas ambientes desconfortáveis (frio ou calor extremos) foram responsáveis por um aumento de $7,71 \%(95 \%$ CI $7,43-7,91)$ na 
mortalidade. $\mathrm{O}$ frio foi o responsável pela maioria das mortes prematuras $7,29 \%$ $(7,02-7,49)$, contra $0,42 \%(0,39-0,44)$ por calor extremo. A grande variabilidade entre os países encontrada no estudo indica uma possível variabilidade da capacidade fisiológica de adaptação a extremos de temperatura das diferentes populações estudadas, mas também, variabilidade na capacidade de adaptação da infraestrutura do país para proteger sua população frente a extremos de temperatura. No Brasil, o frio foi responsável por um aumento de $2,83 \%(2,34-$ $3,30)$ das mortes e o calo,r por 0,70\% $(0,45-0,93)$ (Gasparrini et al., 2015).

Estima-se que a temperatura média no Brasil possa subir entre $2{ }^{\circ} \mathrm{C} \mathrm{e} 4{ }^{\circ} \mathrm{C}$ até 2100, comparado com as médias de temperatura entre 1961 e 1990 (Marengo et al., 2009). No entanto, ao contrário de muitos países desenvolvidos como a Austrália, o Brasil não dispõe atualmente de políticas consistentes para proteger suas populações dos extremos de temperatura.

Modificações no perfil de calor urbano impactam a dispersão de poluentes, a formação de relâmpagos, além de outros processos físicos e químicos do ambiente urbano (Khan; Simpson, 2001). As ondas de calor aumentam a concentração de poluentes atmosféricos nas ilhas de calor urbanas, aumentando a incidência de doenças relacionadas à poluição $\mathrm{e}$ já descritas no item "a" deste artigo.

As ilhas urbanas de calor favorecem a formação de um poluente particular, o ozônio troposférico. Formado a partir de nitrogênio e compostos orgânicos voláteis liberados pela queima de combustíveis fósseis, na presença de luz, o ozônio é mais frequente no final da primavera e começo do outono (Hsieh et al., 1999; Andrade et al., 2004). O ozônio troposférico é fortemente relacionado a crises agudas de asma (Andrade et al., 2004), alterações cardiovasculares e inflamação sistêmica, além de aumento da mortalidade (Bell et al., 2014). Entre 1990 e 2013, a mortalidade ajustada por ozônio no mundo aumentou em $19,8 \%$ e a morbidade medida em DALY, em 32,5\% (Forouzanfar et al., 2015). Idosos são o grupo populacional mais vulnerável (Bell et al., 2014).

Em São Paulo, o gradiente térmico entre a zona central e a periférica da cidade pode atingir $10^{\circ} \mathrm{C}$. Embora São Paulo tenha duas estações bem definidas: primavera-verão (quente e úmido) e outono-inverno (frio e seco), eventos extremos de temperatura têm se tornado mais frequentes na cidade, particularmente pela influência das mudanças climáticas (Bornstein; Lin, 2000). No inverno, a qualidade do ar fica frequentemente prejudicada em São Paulo c a população tem que enfrentar os efeitos deletérios da poluição para a saúde humana descritas no item "a" deste artigo. Como a disponibilidade de energia solar é baixa, a dispersão de poluentes depende em grande parte da força da circulação da ilha de calor (Bornstein; Lin, 2000).

No verão, a diferença de temperatura entre o centro (quente) e a periferia (menos quente) da cidade aumenta eventos de chuva forte nas partes centrais da cidade (Freitas et al., 2007), favorecendo enchentes e seus malefícios à saúde como o aumento da incidência de leptospirose. As enchentes também se rela- 
cionam ao estresse emocional devido aos problemas de imobilidade gerados na cidade e à insegurança da integridade dos bens matérias de pessoas que residem em moradias precárias.

A associação das ilhas de calor e das mudanças climáticas na temperatura dos grandes centros urbanos tende a aumentar a frequência e a intensidade de ondas de calor, períodos de seca e de chuva intensa, com impactos negativos para a saúde e bem-estar de quem vive em cidades. Em Shangai, China, um estudo mostrou que as ilhas urbanas de calor foram diretamente responsáveis por excesso de mortalidade devido a condições extremas de temperatura (Tan et al., 2010). Populações de baixo nível socioeconômico são as mais impactadas (Urban et al., 2014; Burkart et al., 2011).

$\mathrm{O}$ aumento de áreas verdes nos centros urbanos pode resfriar a temperatura do local e do entorno, mitigando as ilhas urbanas de calor e seus malefícios para a saúde. Além disso, muitos estudos têm associado o aumento da cobertura urbana verde a ganhos para a saúde mental (Roe et al., 2010) e cardiovascular (Villeneuve et al., 2012). Outros benefícios relatados incluem resultados positivos sobre mortalidade (Villeneuve et al., 2012), desfechos de nascimento (Ebisu et al., 2016), recuperação de cirurgia (Ulrich, 1984), dor de cabeça (Hartig et al., 2003) e sono (Astell-Burt et al., 2013). A literatura também descreve benefícios para a saúde social como redução da criminalidade (Wolfe; Mennis 2012) e melhoria nas interações sociais (Mass et al., 2009).

Qual seria o mecanismo por trás dos benefícios para a saúde da exposição a áreas verdes? A explicação mais consistente até o momento é que a proximidade a áreas verdes incentivaria a prática de atividade física. Assim, os benefícios para a saúde viriam da adoção de um estilo de vida menos sedentário, reduzindo o risco de doenças cardiovasculares, obesidade, entre outros benefícios. Num estudo realizado em cidades de oito países europeus, a frequência da prática de atividade física entre os residentes de áreas mais verdes foi três vezes maior do que a frequência de moradores de áreas menos verdes (Ellaway et al., 2005). Nos Estados Unidos, um estudo mostrou que morar a menos de 500 metros de um parque na infância reduz o risco de sobrepeso na adolescência (Wolch et al., 2011). No Brasil, estudos transversais mostraram que regiões com alta densidade de parques e locais públicos para a prática esportiva estão associados a menor prevalência de sobrepeso em São Paulo (Jaime et al., 2011) e obesidade em Belo Horizonte (Matozinhos et al., 2015).

Outros possíveis mecanismos relacionados aos benefícios das áreas verdes para a saúde são a redução da poluição do ar (Janhall, 2015) e da água (Dora et al., 2015), além de redução da poluição sonora (Fan et al., 2010) e vulnerabilidade de habitações ante enchentes (Dora et al., 2015).

Além do aumento das áreas verdes dentro das cidades, o uso de matérias com maior potencial reflexivo na superfície de construções melhora a eficiência energética do prédio e pode auxiliar na mitigação das ilhas urbanos de calor (So- 
lecki et al., 2005). A promoção da agricultura urbana, já discutida no item "b" deste artigo, é uma outra estratégia possível.

\section{d) Conforto térmico e qualidade do ar} de ambientes fechados (indoor)

A poluição do ar em ambientes internos figura entre os principais fatores de risco para doenças crônicas na América Latina (Lim et al., 2012), e foi responsável por $7 \%$ das mortes prematuras na região em 2010 (WHO, 2014). A qualidade do ar em ambientes fechados é modulada por ventilação, níveis de poluentes do ambiente externo e produção de poluentes dentro do ambiente (Rydin et al., 2012). Arquitetos e designers estão na posição de melhorar a ventilação e consequentemente a qualidade do ar interno. A fonte de poluição interna mais estudada é a queima de combustíveis sólidos para cozinhar e aquecer o ambiente interno.

Os impactos para a saúde da poluição em ambientes internos incluem aumento no risco de pneumonia em crianças menores de cinco anos e doença pulmonar obstrutiva crônica, doenças cardiovasculares, catarata e câncer de pulmão em adultos (Smith et al., 2013). Como passam a maior parte do tempo na cozinha ou perto dela, mulheres e crianças pequenas são os mais vulneráveis. A falta de acesso a fontes de energia mais limpas também pode resultar em outros riscos para a saúde como queimaduras, acidentes e intoxicação (Dora et al., 2015).

No Brasil, Fortaleza é a região metropolitana com maior porcentagem de residências sem fogão: 1,76\% (IBGE 2010). No entanto, a porcentagem pode ser significativamente maior nos países menos desenvolvidos da América Latina (Smith et al., 2013; Laborde et al., 2015). Fogões movidos a biomassa mais eficientes $\mathrm{e}$ com chaminés (idealmente aqueles que resultam em combustão completa) têm sido uma solução bem-sucedida, como mostrado na queda pela metade da incidência de pneumonia em crianças da Guatemala após a instalação desses fogões (Smith et al. 2011). Esses fogões também reduzem as emissões de gases de efeito estufa, beneficiando a saúde pública e mitigando as mudanças climáticas simultaneamente (Wilkinson et al., 2009). O uso de gás ou eletricidade para cozinhar gera pouca ou nenhuma poluição na cozinha. Assim, eletricidade a preço acessível também resultaria em melhor qualidade do ar interior (Smith et al., 2013).

Outras estratégias para adequar a qualidade do ar interno são aperfeiçoamento na ventilação e iluminação solar das residências, aquecimento interno eficiente e uso de materiais de construção que reduzem a perda de calor pelas paredes, janclas e telhados, entre outras estratégias de redução do uso de energia (Rydin ct al., 2012).

Intervenções residenciais que promovam o aquecimento e a eficiência energética do lar podem melhorar a saúde geral dos moradores, particularmente pessoas com doenças respiratórias prévias (Thomson et al., 2013). Ademais, temperaturas interiores baixas representam maior risco para hipertensão arterial. 
Assim, estratégias de conforto térmico tendem a melhorar a saúde cardiovascular (Shiue; Shiue, 2014).

A fumaça do tabaco em ambientes fechados também é uma fonte reconhecida de poluição do ar interna (Laumbach; Kipen, 2014). Essa exposição pode ser eficientemente reduzida mediante políticas de restrição do fumo em ambientes fechados (Sebrié et al., 2008), como já é feito em diversas cidades no mundo e no Brasil.

O amianto é uma substância carcinogênica (IARC, 2009) relacionada a diversas doenças do pulmão (O'Reilly et al., 2007), incluindo, além de câncer, abestose (Bledsoe et al., 2014). Resistente ao fogo e com propriedades isolantes e de absorção do som, o amianto era misturado ao cimento na construção de materiais, especialmente telhados (Haynes, 2010). O amianto foi banido na maioria dos países desenvolvidos (Laborde et al., 2015). Na América Latina, Argentina, Chile, Uruguai e Honduras também baniram a substância (ibidem). Para melhorar a qualidade do ar interior, seria interessante que arquitetos, engenheiros e demais responsáveis por construções onde o amianto ainda não foi banido optassem por materiais sem amianto na sua composição. $\mathrm{O}$ mesmo vale para outros componente tóxicos como o formaldeído (Wang; Zang, 2009).

\section{e) Saneamento}

A Organização das Nações Unidas (ONU) considera o acesso à água segura e ao saneamento direitos humanos básicos (United Nations, 2010). A falta de acesso à água segura para beber, saneamento $\mathrm{e} /$ ou higiene afeta gravemente a saúde humana (WHO; Unicef 2014). O principal impacto são surtos de diarreia e consequente aumento da mortalidade infantil. No entanto há uma série de outras doenças reconhecidamente relacionadas como desnutrição, doenças causadas por vetores (exemplo dengue), doenças tropicais negligenciadas (exemplo esquistossomose) $\mathrm{e}$ doenças relacionadas a contaminantes químicos presentes na água (Freeman et al., 2013; Bartram et al., 2005). Devido à maior prevalência de falta de acesso a fontes de água potável e ao saneamento em populações de baixa renda, estas são as mais vulneráveis (Dora et al., 2015).

Na América Latina, o acesso a água potável para beber atingiu $94 \%$ da população em 2012 (WHO; Unicef, 2014). No entanto, mudanças no regime de chuvas, rápido crescimento populacional, alto consumo, falta de planejamento e investimentos, entre outros fatores, desafiam o fornecimento de água potável nos grandes centros urbanos.

A fundação de uma companhia para o fornecimento de água para as residências de São Paulo no final do século XIX foi um marco do início das medidas sanitárias no Brasil. No entanto, o esgoto não recebeu a mesma atenção. A primeira lei para regular a poluição das águas em São Paulo data de 1940. E ainda hoje, a taxa de tratamento do esgoto do estado de São Paulo é de 53,34\% (Sistema Nacional de Informações sobre Saneamento, 2013). Uma possível explicação reside no fato de os investimentos em oferta de água potável serem 
percebidos como prioritários comparados à coleta $\mathrm{e}$ tratamento de esgoto, tanto pela população quanto pelos governantes (Rydin et al., 2012).

Esgoto não tratado contribui para acúmulo excessivo de nutrientes nos corpos de água doce (eutrofização), e consequente proliferação de cianobactérias nos reservatórios de água (Cheung et al., 2013). As cianobactérias produzem metabólitos tóxicos para a saúde (ibidem), alguns reconhecidamente carcinogênicos, como a microcistina (IARC 2010). O meio ambiente também é prejudicado (morte de peixes, por exemplo), o que impacta também as atividades turísticas.

Segundo a Organização Mundial da Saúde, uma fonte de água potável segura é aquela protegida de contaminação externa, especialmente contaminação por fezes. Já uma infraestrutura de saneamento adequada é aquela que separa de forma higiênica os excrementos humanos do contato humano como vasos sanitários, sistemas de esgoto canalizado, fossas sépticas, vários tipos de latrinas e banheiros de compostagem (WHO; Unicef; 2014). No entanto a classificação errônea (classificar suprimento de água e esgoto como adequado, quando na verdade não atinge critérios básicos para tal) é frequente (Rydin et al., 2012); e fontes de fornecimento de água consideradas potáveis ainda podem conter contaminação por bactérias ou químicos (Dora et al., 2015).

Além disso, estima-se que os períodos de falta de água nas cidades se tornaram mais frequentes por causa das mudanças climáticas (Dora et al., 2015), ameaçando as conquistas no suprimento de água potável e saneamento alcaņ̧adas até o momento. Em 2015, o nível dos reservatórios de água da cidade de São Paulo caiu drasticamente. No começo do ano, a cidade enfrentou uma severa epidemia de dengue. As mudanças no fornecimento de água e o armazenamento inadequado de água da chuva em conjunto podem ter contribuído para o aumento nos casos de dengue em 2015.

Idealmente, todas as residências deveriam ter suprimento de água tratada para banheiros e cozinha, vasos sanitários e sistemas de drenagem de água da chuva para prevenir enchentes. No entanto essa realidade não atinge todos os residentes urbanos, particularmente os moradores de favelas (Rydin et al., 2012).

No Rio de Janeiro, 1,39 milhão de pessoas vivem em favelas. O acesso a água tratada e saneamento para essas populações é menor, comparado com os demais residentes da cidade (Snyder et al., 2013). O desafio de reduzir essa desigualdade é definir quem vai de fato pagar pela infraestrutura completa. A instalação de vasos sanitários dentro das residências costuma ser responsabilidade individual do morador e não das autoridades governamentais. Famílias de baixa renda, em especial aquelas que moram de aluguel em assentamentos informais, podem ter dificuldades em pagar por essa infraestrutura (Rydin et al., 2012).

\section{Considerações funais}

Os tópicos descritos separadamente neste artigo se sobrepõem sistematicamente aumentando a magnitude dos efeitos para a saúde das exposições 
urbanas. Por exemplo, uma possibilidade de aumentar as áreas verdes discutidas no item "c" deste artigo é a promoção da agricultura urbana com implicações discutidas no item "b". Outra estratégia possível é o aumento do número de parques nas cidades.

Parques estão associados a um aumento no nível de atividade física, o que impacta positivamente a obesidade e outras doenças crônicas. Um estudo conduzido nos Estados Unidos entre 1993 e 1996 mostrou que crianças com acesso facilitado a parques e programas de recreação apresentavam menores índices de obesidade (Wolch et al., 2011). Também nos Estados Unidos, um estudo mostrou que comunidades de baixa renda têm acesso restrito a parques (ibidem). Além disso, os parques costumam ser mais poluídos em áreas de baixa renda (Su et al., 2011). Não é difícil imaginar que a situação no Brasil seja semelhante.

Neste artigo, propusemos uma discussão a partir dos cinco tópicos propostos por Rydin et al. (2012). No entanto, outras intervenções urbanas igualmente moldam a saúde nas cidades e não devem ser ignoradas. Por exemplo, um estudo conduzido por Epstein et al. (2012) mostrou que crianças que moram em bairros com menos lojas de conveniência e supermercados apresentam menor índice de obesidade.

A forma como as cidades funcionam influencia significativamente a saúde de seus moradores. Entender como se dá essa influência é um grande desafio metodológico, em razão das inúmeras variáveis envolvidas num sistema complexo como uma cidade. O uso de ferramentas metodológicas usadas para estudar sistemas é de grande valia no entendimento dos impactos do ambiente construído para a saúde. As evidências discutidas já oferecem direcionamentos sobre quais exposições presentes nos ambientes urbanos deveriam ser evitadas ou promovidas. Promover efetivamente as mudanças urbanísticas necessárias a uma cidade mais saudável requer a interação multidisciplinar entre diversas pastas do governo, a sociedade civil e outros atores da sociedade. Apesar da magnitude do desafio, o objetivo parece ser forte o suficiente para consensos efetivos, afinal uma cidade que promova a saúde de sua população é interesse de todos.

Ademais, uma cidade saudável deveria ser interesse particular dos profissionais de saúde, pois cla representa um grande auxílio terapêutico no enfrentamento de doenças e promoção da qualidade de vida.

\section{Referências}

AKBARI, H. Energy Saving Potentials and Air Quality Benefits of Urban Heat Island Mitigation. Lawrence Berkeley National Laboratory. 2005. Disponível em: <http:// www.osti.gov/scitech/servlets/purl/860475>. Acesso em: 8 jun. 2015.

ANALITIS, A. et al. Effects of cold weather on mortality: results from 15 European cities within the PHEWE Project. Am J Epidemiol., v.168, p.1397, 2008. 
ANDERSON, B.G.; BELL, L. Weather-related mortality: how heat, cold, and heat waves affect mortality in the Unitated States. Epidemiology, v.20, n.2, p.205-213, 2009.

ANDRADE, L. H. et al. Mental disorders in megacities: findings from the São Paulo megacity mental health survey, Brazil. PLoS One, v.7, n.2, p.e31879, 2012.

ANDRADE, M. F. et al. Air-quality model simulating photochemical formation of pollutants: the São Paulo Metropolitan Area, Brazil. International Journal Environment and Pollution, v.22, n.4, p.460-75, 2004.

ANGNOTTI, T. Urban agriculture: long-term strategy or impossible dream? Lessons from Prospect Farm in Brooklyn, New York. Public Health, p.1-6, 2015.

ARAUJO R. V et al. São Paulo urban heat islands have a higher incidence of dengue than other urban areas. Braz J Infect Dis, v.19, n.2, p.146-55, 2015.

ASTELL-BURT, T.; FENG, X.; KOLT, G. S. Does access to neighbourhood green space promote a healthy duration of sleep? Novel findings from a cross-sectional study of 259319 Australians. BMJ Open 3, 2013.

BARTRAM, J. et al. Focusing on improved water ans sanitation for health. Lancet, v.365, n.9461, p.819-12, 2005.

BECERRA, J. M. et al. Transport and health: a look at three Latin American cities. Cad. Saúde Pública, v.29, n.4, p.654-66, 2013.

BELL, M. L.; ZANOBETTI, A.; DOMINICI, F. Who is more affected by ozone pollution? A systematic review and meta-analysis. Am J Epidemiol., v.180, n.1, p.15-28, 2014.

BERDAHL, P.; BRETZ, S. Preliminary survey of the solar reflectance of cool roofing materials. Energy and Buildings, v.25, p.149-58, 1997.

BLEDSOE, J. R.; CHRISTIANI, D. C.; KRADIN, R. L. Smoking-associated fibrosis and pulmonary asbestosis. Int J Chron Obstruct Pulmon Dis, v.10, p.31-7, 2014.

BRAGA, A. L. F.; ZANOBETTI, A.; SCHWARTZ, J. The effect of weather on respiratory and cardiovascular deaths in 12 U.S. cities. Environmental Health Perspectives, v.110, n.9, p.859-63, 2002.

BORNSTEIN, R.; LIN, Q. Urban heat islands and summertime convective thunderstorms in Atlanta: three case studies. Atmos Environ., v.34, p.507-16, 2000.

BURKART, K. et al. The effect of atmospheric thermal conditions and urban thermal pollution on all-cause and cardiovascularmortality in Bangladesh. Environ Pollut., v.159, n.8-9, p.2035-43, 2011.

CALDERÓN-GARCIDUENAS, L. et al. Long-term air pollution exposure is associated with neuroinflammation, an altered innate immune response, disruption of the blood-brain barrier, ultrafine particulate deposition, and accumulation of amyloid beta- 42 and alpha-synuclein in children and young adults. Toxicol Pathol., v.36, n.2, p.289-310, 2008.

CENTRAL OF DISEASE CONTROL - CDC. Extreme Heat: A Prepention Guide to Promote Your Personal Health and Safety. 2004. Disponivel em: <http://www.bt.cdc. gov/disasters/extremeheat/heat_guide.asp>. Acesso em: 8 jun. 2015.

CHETTY, R; HENDREN, N.; KATZ, L. The Effects of Exposure To Better Neighborhoods on Children: New Evidence from The Moving to Opportunity Experiment. Working Paper 21156. Harvard University, 2015. 
CHEUNG, M. Y.; LIANG, S.; LEE, J. Toxin-producing Cyanobacteria in Freshwater: A Review of the Problems, Impact on Drinking Water Safety, and Efforts for Protecting Public Health. Journal of Microbiology, v.51, n.1, p.1-10, 2013.

CINTRA, M. Os custos dos congestionamentos na cidade de São Paulo. Textos para Discussão da Escola de Economia de São Paulo da Fundação Getulio Vargas FGV-EESP, 2014.

COELHO-ZANOTTI, M. S. S.; MASSAD, E. The impact of climate on Leptospirosis in São Paulo, Brazil. International Journal of Biometeorology, v.56, n.2, p.233-41, 2012.

DORA, C. et al. Indicators linking health and sustainability in the post-2015 development agenda. Lancet, v.385, p.380-91, 2015.

EBISU, K.; HOLFORD, T. R.; BELL, M. L. Association between greenness, urbanicity, and birth weight. Sci Total Environ, v.542, p.750-6, 2016.

ELLAWAY, E.; MACINTYRE, S.; BONNEFOY, X. Graffiti, greenery, and obesity in adults: secondary analysis of European cross sectional survey. $B M$ J , v.331, p.611-12, 2005 .

EPSTEIN, L. H. et al. The built environment moderates effects of family-based childhood obesity treatment over 2 years. Ann Behav Med, v.44, n.2, p.248-58, 2012.

FAN, Y. et al. The investigation of noise attenuation by plants and the corresponding noise-reducing spectrum. J Environ Health, v.72, p.8-15, 2010.

FAO. Growing greener cities in Latin America and the Caribbean: a FAO report on urban and peri-urban agriculture in the region. Rome, 2014.

FOROUZANFAR, M. H.; ALEXANDER, L.; ANDERSON, H. R. Global, regional, and national comparative risk assessmentof 79 behavioural,environmental and occupational, and metabolic risks or clusters of risks in 188 countries,1990-2013: a systematic analysis for the Global Burden of Disease Study 2013. Lancet, 2015. Disponível em: <http://dx.doi.org/10.1016/S0140-6736(15)00128-2>.

FREEMAN, M. C. et al., Integration of water, sanitation, and hygiene for the prevention and control of neglected tropical diseases: a rationale for inter-sectoral collaboration. PLosS Neglected Tropical Disease, v.7, n.9, p.1-9, 2013.

FREITAS, E. D. et al. Interactions of an urban heat island and sea-breeze circulations during winter over the metropolitan area of São Paulo, Brazil. Boundary-Layer Meteorology, v.122, n.1, p.43-65, 2007.

GASPARRINI, A. et al. The effect of high temperatures on cause specific mortality in England and Wales. Occup Environ Med., v.69, n.1, p.56-61, 2012.

GASPARRINI, A. et al. Mortality risk attributable to high and low ambient temperature: a multicountry observational study, Lancet, 2015.

GATTO, N. M. et al. LA sprouts randomized controlled nutrition and gardening program reduces obesity and metabolic risk in latino youth. Obesity, v.23, n.6, p.1244-51, 2015.

GOMEZ, L. F. et al. Urban environment interventions linked to the promotion of physical activity: a mixed methods study applied to the urban context of Latin America. Soc Sci Med, v.131, p.18-30, 2015.

GOUVEIA, N. et al. Hospitalizações por causas respiratórias e cardiovasculares associa- 
das à contaminação atmosférica no Município de São Paulo, Brasil pollution in the city of São Paulo, Brazil. Cadernos de Saúde Pública, v.22, n.12, p.2669-77, 2006.

HAINES, A. et al. Public health benefits of strategies to reduce greenhouse-gas emissions: overview and implications for policymakers. Lancet, v.374, n.9707, p.2104-14, 2009.

HARA, Y. et al. Quantitative assessment of the Japanese "local production for local consumption" movement: a case study of growth of vegetables in the Osaka city region. Sustain Sci., v.8, p.515-27, 2013.

HARTIG, T. et al. Tracking restoration in natural and urban field settings. J. Environ. Psychol., v.23, p.109-23, 2003.

HAYNES, R. C. Aworn-out welcome: renewed call for a global ban on absbestos. Environmental Health Perspectives, v.118, n.7, p.298-303, 2010.

HEI. Panel on the Health Effects of Traffic-Related Air Pollution. Traffic-Related Air Pollution: A Critical Review of the Literature on Emissions, Exposure, and Health Effects. HEI Special Report 17. Health Effects Institute, Boston, MA 2010. Diponível em: <http://pubs.healtheffects.org/getfile.php? u=553>.

HSIEH, C.; CHANG, K.; KAO, Y. Estimating the ozone formation potential of volatile aromatic compounds in vehicle tunnels. Chemosphere, v.39, p.1433-44, 1999.

HU, F. B.; MANSON, J. E.; WILLETT, W. C. Types of dietary fat and risk of coronary heart disease: a critical review. J Am Coll Nutr., v.20, n.1, p.5-19, 2011.

IARC - International Agency for Research on Cancer. A review of human carcinogens. Part C: Arsenic, metals, fibres, and dusts - IARC Working Group on the Evaluation of Carcinogenic Risks to Humans. Lyon, France: International Agency for Research on Cancer, 2009. Disponível em: <http://monographs.iarc.fr/ENG/Monographs/ voll00C/monol00C.pdf>. Acesso em: 30 maio 2015.

World Health Organization International Agency For Research On Cancer. Monographs on the Evaluation of Carcinogenic Risks to Humans: Ingested Nitrate and Nitrite, and Cyanobacterial Peptide Toxins. v.94, 2010. Disponível em: <http:// monographs.iarc.fr/ENG/Monographs/vol94/mono94.pdfs.

JAIME, P. C. et al. Investigating environmental determinants of diet, physical activity, and overweight among adults in Sao Paulo, Brazil. J Urban Health, v.88, n.3, p.567$81,2011$.

JANHALL, S. Review on urban vegetation and particle air pollution e Deposition and dispersion. Atmos Environ, v.105, p.130-7, 2015.

KESSLER R. Urban gardening: managing the risks of contaminated soil. Environ $\mathrm{He}^{-}$ alth Perspect, v.121, n.11 e 12, p.326-33, 2013.

KHAN, S. M.; SIMPSON, R. W. Effect of a heat island on the meteorology of complex urban airshed. Boundary-Layer Meteorol., v.100, p.487-506, 2001.

LABORDE, A. et al. Children's Health in Latin America: The Influence of Environmental Exposures. Environmental Health Perspectives, v.123, n.3, p.201-10, 2015.

LASCHEWSKI, G.; JENDRITZKY. G. Effects of the thermal environment on human health: an investigation of 30 years of daily mortality data from SW Germany. Climate Research, v.21, p.91-103, 2002. 
LAUMBACH, R.; KIPEN, H. Mechanistic data support protecting non-smokers from the lethal effects of second-hand smoke. International Journal of Public Health, v.59, n.4, p.575-6, 2014.

LAVERTY, A. A. et al. Associations between active travel and weight, blood pressure and diabetes in six middle income countries: a cross-sectional study in older adults. Int J Behav Nutr Phys Act, v.20, p.12-65, May 2015.

LIM, S. S. et al. A comparative risk assessment of burden of disease and injury attributable to 67 risk factors and risk factor clusters in 21 regions, 1990-2010: a systematic analysis for the Global Burden of Disease Study 2010. Lancet, v.380, p.2224-60, 2012.

LOOMIS, D. et al. International Agency for Research on Cancer Monograph Working Group LARC. The carcinogenicity of outdoor air pollution. Lancet Oncol, v.14, n.13, p.1262-3, 2013.

MAAS, J. et al. Morbidity is related to a green living environment. JEpidemiol Community Health, v.63, p.967-73, 2009.

MARENGO, J. A. et al. Future change of temperature and precipitation extremes in South America as derived from the PRECIS regional climate modeling system. International Journal of Climatology, v.29, n.15, p.2241-55, 2009.

MATOZINHOS, F. P. et al. Neighbourhood environments and obesity among adults: A multilevel analysis of an urban Brazilian context. Pren Med Rep, v.29, n.2, p.337-41, 2015 .

MCMICHAEL, A. J. Transport and health: assessing the risks. In: FLETCHER, T.; MCMICHAEL, A. J. (Ed.) Health at the crossroads. transport policy and urban health Chichester: John Wiley \& Sons, 1996. p.9-26.

MIDDLE, I. et al. Integrating community gardens into public parks: an innovative approach for providing ecosystem services in urban areas. Urban Forestry \& Urban Greening, v.13, p.638-45, 2014.

MILBOURN, L. S.; VAIL, B.A. Sowing the seeds of success: cultivating a future for community gardens. Landscape Journal, v.29, p.1-10, 2010.

MUELLER, N. et al. Health impact assessment of active transportation: A systematic review. Prev Med, v.18, n.6, p.103-14, 2015.

NAWROT, T. S. et al. Public health importance of triggers of myocardial infarction: a comparative risk assessment. Lancet, v.26, n.377(9767), p.732-40, 2011.

NEWMAN, P.; KENWORTHY, G. Cities and sustainability: reducing auto dependency. Washington, DC: Island Press, 1999.

O'REILLY, K. M. A. et al. Asbestos-related lung disease. American Family Physician, v.75, n.5, p.683-8, 2007.

OLLILA, E. Health in All Policies: From rhetoric to action. Scandinavian Journal of Public Health, v.39, n.6, p.11-18, 2011.

PUCHER, J.; BUEHLER, R. At the frontiers of cycling: policy innovations in the $\mathrm{Ne}$ therlands, Denmark, and Germany. World Transport Policy er Practice, v.13, p. 9-56, 2007. RISSEL, C. E. Active travel: a climate change mitigation strategy with co-benefits for health. NSW Public Heal. Bull., p.20-13, 2009. 
ROE, J. J. et al. Green space and stress: Evidence from cortisol measures in deprived urban communities. Int J Environ Res Public Health, v.10, p.4086-4103, 2010.

RYDIN, Y. et al. Shaping cities for health: complexity and the planning of urban environments in the 21st century. Lancet, v.379, n.9831, p.2079-2108, 2012.

SALDIVA, P. H. N.; KING, H.; DELMONTEETAL, V. L. C. Respiratory alterations due to urban air pollution: an experimental study in rats. Environmental Research, v.57, n.1, p.19-33, 1992.

SANTOS, T. O. et al. Influence of urbanization on land surface temperature in Recife city. Eng Agric, v.33, n.6, p.1234-44, 2013.

SEBRIÉ, E. M.; SCHOJ, V.; GLANTZ, S. A. Smoke free environments in Latin America: on the road to real change? Prevention and Control, v.3, p.21-35, 2008.

SENA, C. A. P.; FRANCA, J. R. de A.; PERES, L. F. Estudo da Ilha de Calor na Região Metropolitana do Rio de Janeiro Usando Dados do MODIS. Anu. Inst. Geocienc. [online], v.37, n.2, p.111-22, 2014.

SHIUE, I.; SHIUE, M. Indoor temperature below $18^{\circ} \mathrm{C}$ accounts for $9 \%$ population attributable risk for high blood pressure in Scotland. International Journal of Cardiology, v.171, p.el-e2, 2014 .

SILVA DIAS, M. M. F. et al. Changes in extreme daily rainfall for São Paulo, Brazil. Climatic Change, v.116, n.3-4, p.705-22, 2013.

SISTEMA NACIONAL DE INFORMAÇÃOSOBRESANEAMENTO-SIS. 2013. Disponível em: $<$ http: //www.snis.gov.br/PaginaCarrega.php?EWRErterterTERTer=105>. Acesso em: 15 ago. 2015.

SMITH, K. R. et al. Effect of reduction in household air pollution on childhood pneumonia in Guatemala (RESPIRE): a randomised controlled trial. Lancet, v. 378, p.1717$26,2011$.

SMITH, K. R. et al. Energy and Human Health. Annu. Rev. Public Health, v.34, p.159$88,2013$.

SNYDER, R. E. et al. A comparison of social and spatial determinants of health between formal and informal settlements in a large metropolitan setting in Brazil. Journal of Urban Health: Bulletin of the New York Academy of Medicine, v. 91, n.3, p.432-55, 2013.

SOBRAL, R. H. Heat Island in Săo Paulo, Brazil. Critical Public Health, v.15, n.2, p.147-56, 2005 .

SOLECKI, W. D. et al. Mitigation of the heat island effect in urban New Jersey. Global Environmental Change Part B: Environmental Hazards, v.6, n.1, p.39-49, 2005.

SOUZA, E. L. L.; MACEDO, I. Etanol e bioeletricidade: A cana-de-açucar no futuro da matriz energética. UNICA - União da Indústria de Cana-de-açúcar, 2010.

STIEB, D. M. Ambient air pollution, birth weight and preterm birth: A systematic review and meta-analysis. Environmental Research, v.117, p.100-11, 2012.

$\mathrm{SU}, \mathrm{J}$. G. et al. Does exposure to air pollution in urban parks have socioeconomic, racial or ethnic gradients? Environmental Research, v.111, p.319-28, 2011.

SWINTON, S. M. et al. Ecosystem services and agriculture: Cultivating agricultural ecosystems for diverse benefits. Ecological Economics, v.64, 2007. 
TAN, J. et al. The urban heat island and its impact on heat waves and human health in Shanghai. Int J Biometeorol, v.54, p.75-84, 2010.

THOMSON, H. et al. Housing improvements for health and associated socioeconomic outcomes (Review). Cochrane Database Syst Rev. 2 (CD008657), v.1, p.333, 2013.

TOHILL, B. C. et al. What epidemiologica studies tell us about the relationship between fruit and vegetable consumption and body weight. Nutrition Reviews, v.62, n.10, p.365-74, 2004 .

TORREGGIANI, D.; DALL'ARA, E.; TASSINARI, P. The urban nature of agriculture: Bidirectional trends between city and countryside. Cities, v.29, p.412-16, 2012.

ULRICH, R. S. Views through a Windows may influence recovery from surgery. Scien$c e$, v.224, p.420-1, 1984.

UNITED NATIONS. General Assembly, Resolution 62/292, from july, 21st, 2010. Disponível em http://www.un.org/es/comun/docs/?symbol=A/RES/64/ 292\&lang=E $>$. Acesso em: 15 mar. 2016.

URBAN, A.; DAVÍDKOVOVÁ, H.; KYSELÝ, J. Heat- and cold-stress effects on cardiovascular mortality and morbidity among urban and rural populations in the Czech Republic. Int J Biometeorol, v.58, n.6, p.1057-68, 2014.

VILLENEUVE, P. J. et al. A cohort study relating urban green space with mortality in Ontario, Canada. Environ Res, v.115, p.51-8, 2012.

WANG, X.; ZHANG, Y. A new method for determining the initial mobile formaldehyde concentrations, partition coefficients, ans diffusion coefficients of dry building material. Journal of the Air \& Waste Management Association,v.69, n.7, p.819-25, 2009.

WATTS, N. et al Health and climate change: policy responses to protect public health. Lancet. Published Online: 22 June 2015.

WHAT Epidemiologic Studies Tell Us about the Relationship between Fruit and Vegetable Consumption and Body Weight. Nutrition Reviews, v.62, n.10, p.365-74, 2004.

WILKINSON, P. et al. Public health benefits of strategies to reduce greenhouse-gas emissions: household energy. Lancet, v.374, p.1917-29, 2009.

WOLCH, J. R.; BYRNE, J.; NEWELL, J. P. Urban green space, public health, and environmental justice: The challenge of making cities 'just green enough'. Landscape and Urban Planning, v.125, p.234-44, 2014.

WOLCH, J. R. et al. Childhood obesity and proximity to urban parks and recreational resources: a longitudinal cohort study. Health Place, v.17, p.207-14, 2011.

WOLEE, M. K.; MENNIS, J. J. Does vegetation encourage or suppress urban crime? Evidence from Philadelphia, PA. Landscape Urban Plann, v.108, p.112-22, 2012.

WORLD HEALTH ORGANIZATION. Health in the green economy: health co-benefits of climate change mitigation - the transport sector. 2011. Disponível em: <http://www.who.int/hia/examples/trspt_comms/hge_transport_lowresdurban_30_11_2011.pdf>. Acesso em: 15 de jan. 2014.

WORLD HEALTH ORGANIZATION and UNICEF - WHO/UNICEF. Progress on Drinking Water and Sanitation - update 2014. Switzerland, 2014. Disponível em: <http://www.who.int/water_sanitation_health/publications/2014/jmp-report/ en/>. Acesso em: 2 maio 2015. 
ZEZZA, A.; TASCIOTTI, L. Urban agriculture, poverty, and food security: Empirical evidence from a sample of developing countries. Food Policy, v.35, p.265-73, 2010.

RESUMO - Morar próximo a um parque pode reduzir o risco de infarto do miocárdio, enquanto a exposição à poluição do ar ambiente aumenta o risco. Evidências associam a exposição crônica ao ruído do tráfego ao ganho de peso. Em 2014, mais de mil pessoas morreram no trânsito de São Paulo. No entanto, recomendar que as pessoas fiquem em casa com as janelas fechadas é inviável. A adoção de hábitos saudáveis é favorecida ou dificultada pelo ambiente construído e pelo modo como a cidade está organizada. Além disso, alguns fatores de risco para doenças, como a exposição à poluição do ar, vão além de escolhas individuais e dependem, em grande parte, de ações governamentais. Neste artigo discutimos os aspectos que podem favorecer ou dificultar a promoção da saúde nas cidades, a partir dos tópicos propostos por Rydin et al. (2012).

PALAVRAS-CHAVE: Saúde, Cidade, Ambiente construído, Políticas públicas.

ABSTRACT - Living near a park can reduce the risk for myocardial infarction, while exposure to outdoor air pollution increases it. There is evidence associating chronic exposure to traffic noise and weight gain. In 2014, more than one thousand people died in the São Paulo's traffic. However, recommending that people stay home with the windows closed is unfeasible. The adoption of healthy habits is aided or hindered by the man-made environment and by how the city is organized. Moreover, some risk factors for disease, such as exposure to air pollution, are beyond individual choices and call for governmental actions. In this paper, we discuss features that may aid or hinder the promotion of health in the city, based on a framework proposed by Rydin et al. (2012).

KEXWORDS: Health, City, Man-made environment, Public policies.

Laís Fajersztajn é pesquisadora e doutorada no Laboratório de Poluição Atmosférica Experimental da Faculdade de Medicina da Universidade de São Paulo (LIM 05); graduada em Fisioterapia e especialista em reabilitação gerontológica.

(a) - laisfajer@gmail.com

Mariana Verasé bióloga, doutora em Fisiopatologia e especialista em Políticas Públicas e Planejamento Estratégico pela UnB. Atua como pesquisadora científica do Estado de São Paulo, junto ao Hospital das Clínicas - LIM 05, no Departamento de Patologia da Universidade de São Paulo. @ - verasine@usp.br

Paulo Hilário Nascimento Saldipa é médico patologista, professor titular do Departamento de Patologia da Faculdade de Medicina da Universidade de São Paulo e diretor do Instituto de Estudos Avançados da Universidade de São Paulo (2016-2020). (a) - pepino@usp.br

Recebido em 2.3.2016 e aceito em 15.3.2016.

I, III Faculdade de Medicina,Universidade de São Paulo. São Paulo/São Paulo, Brasil.

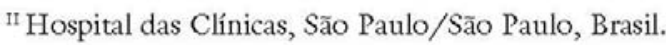


4.4. 4. Artigo na revista Urbe

Urbe é uma revista brasileira de Gestão Urbana. Neste artigo ${ }^{(11)}$, utilizei as evidências científicas da literatura para construir uma narrativa sobre cidades e qualidade de vida para urbanistas. Parte de uma edição especial sobre Urbanismo Ecológico publicada em 2015, a narrativa procurou estabelecer relações entre esta visão da arquitetura (urbanismo ecológico) e qualidade de vida, enfatizando que saúde ecológica e humana não são conceitos contraditórios, mas alinhados e poderiam ser usados em conjunto. A seguir apresento o artigo na íntegra. 


\section{How can ecological urbanism promote human health?}

Como o urbanismo ecológico pode promover a saúde humana?

Lais Fajersztajn ${ }^{[0]}$, Nilmara de Oliveiro Alves[e], Micheline de Souza Zanotti Staglionario Coelho ${ }^{[a]}$, Mariana Matera Veros ${ }^{[a, 4}$,

Poulo Hilário Nascimento Soldivo $0^{[e, d}$

[a] Universidade de São Paulo (USP), Faculdade de Medicina, Departamento de Patologia, Laboratório de Poluição Atmosférica Ambiental (LIM05), São Paulo, SP, Brasil

(b) Center for Air Quality and Health Research and Evaluation, Sydney, Australia

${ }^{[4]}$ Instituto Nacional de Análise Integrada do Risco Ambiental (INAIRA), São Paulo, SP, Brasil

\section{Abstract}

This special issue of URBE dedicated to Ecological Urbanism focuses on the role architects, landscape designers and urban planners can play in promoting healthier cities in Latin America. In this paper, we survey some of the empirical evidence that links the built environment with particular health outcomes. For many centuries, urban settlements were associated with adverse health outcomes, especially related to untreatable epidemics. As the science of disease transmission developed throughout the nineteenth century, the infrastructure of cities was transformed to promote improved public health. Significant gains were made, but in much of the world - Latin America included - urban health still remains a major challenge, all the more so as drug resistant strains of disease have become more prevalent. We believe Ecological Urbanism offers a promising framework for addressing these challenges. Distinguished by its integrated, multi-disciplinary foundation, Ecological Urbanism directly links both population and habitat health. This creates a natural opportunity for the design professions to play a more consequential role in shaping the health of urban settlements and, by extension, the regions they center.

Keywords: Urban health. Healthy cities. Ecological urbanism. Air pollution. Urban food production.

\section{Resumo}

Esta edição especial sobre urbanismo ecológico da revista Urbe destaca o esforço de arquitetos, urbanistas e designers em contribuir para cidades mais sustentáveis na América Latina. $O$ objetivo deste estudo é oferecer aos arquitetos e urbanistas evidências científicas sobre como o meio ambiente urbano impacta a saúde. Historicamente, o viver nas cidades primeiro se associou com piores condições de saúde, representando um risco maior para cólera e doenças infecciosas. Depois das medidas sanitárias, viver nas cidades passou a

LF is physiotherapist, specialist, e-mail: laisfajer@gmail.com

NOA is biologist, PhD,e-mail: nilmaraoalves@gmail.com

MSZSC is meteorologist, PhD, e-mail: coelhomicheline@gmail.com

MMV is biologist, PhD, e-mail: verasine@usp.br

PHNS is doctor, academic teacher, e-mail: pepino@usp.b

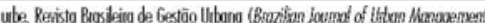


ser uma vantagem para a saúde, quando comparado com a vida rural. Atualmente, a América Latina ainda convive com doenças infecciosas características do passado, ao mesmo tempo em que enfrenta um aumento crescente na incidência de doenças crônicas, classe de doenças que prevalecem na cidade e são modificadas pelo ambiente urbano. Com foco multidisciplinar e abordagem fluída entre diferentes escalas de análise, o Urbanismo Ecológico surge como uma solução promissora para proteger simultaneamente a saúde das pessoas e do planeta. Nós esperamos que, depois desta discussão, arquitetos e urbanistas usem a abordagem do Urbanismo Ecológico para abraçar a ideia de proteger a saúde através do exercício de suas profissões.

Palavras-chave: Cidades saudáveis. Urbanismo ecológico. Mobilidade urbana. Poluição do ar. Agricultura urbana.

\section{Introduction}

Changes in cities with the goal of increasing the energy efficiency of buildings, access to low-cost active transportation, and access to green spaces are key steps simultaneously to address climate change and to promote human health (Watts et al., 2015). Eighty percent of the population of Latin America (LA) live in urban areas, and inadequate or unplanned basic infrastructure remains a prevailing condition in many cities of this part of the world. Urban planners, architects and designers are in the position to reverse, or at least to mitigate, most of the unhealthy exposures characteristic of city environments, and the Ecological Urbanism (EU) approach offers a promising framework for addressing these challenges. Distinguished by its integrated, multi-disciplinary foundation, EU directly links population and habitat health, creating a natural opportunity for the design professions to play a more consequential role in shaping the health of urban settlements and, by extension, the regions in which they are centered.

In this paper, we aimed to provide architects and urban planners with empirical evidence about how city environments impact human health. Although there is a growing body of evidence relating city environments to human health, many questions remain unanswered due to the methodological challenges of addressing all of the variables of a complex system such as a city, as well as variability among local city realities.Furthermore, very robust scientific evidence is necessary to change practices linked to economic activities in complex scenarios. In a previous study, we showed that high local knowledge production in the field of air pollution was correlated with better local air quality at the national level (Fajersztajn, et al., 2013). Nawrot and colleagues (2011) showed that air pollution is an important trigger of myocardial infarction, similar in magnitude to other well-accepted risk factors (e.g., physical exertion and alcohol consumption), but the stringency of national air quality standards remains greatly different among countries (Vahlsing \& Smith 2012). Scientists began to associate tobacco with severe health impacts in the early 50s (Doll \& Hill, 1954), but important health-related polices were not implemented in some cities for a long time or were not implemented at all in other cities. Sao Paulo banned smoking in public spaces in 2009, other Brazilian cities banned it in 2014, but Havana has not banned it at all. Thousands of scientists at the IPCC (Intergovernmental Panel on Climate Change) endorsed the scientific evidence for climate change. However, we still do not have a global climate agreement. Without such robust scientific evidence, the international community would likely not be discussing a climate agreement at all (IPCC, 2013).

In this paper, we propose a discussion of the links between the built environment and public health from five thematic standpoints: a) transportation, mobility, and physical activity; b) urban food production; c) urban heat islands; d) thermal comfort and indoor air quality; and e) sanitation and wastewater management. Although we discuss these topics separately, there are overlaps between them. We classified the thematic areas according to Rydin et al. (2012) study because they discussed the role of urban planning in implementing health improvements from the perspective of health, which is our research field.

Despite the progress in the domains listed made over many decades, long before the term EU was coined, the resulting benefits were not experienced by all of the residents of LA cities. Furthermore, city environments are constantly changing (e.g., aging populations, new technologies, and climate change), requiring new and/or flexible approaches to urbanism 
projects. Fluid in scale and with a disciplinary focus, EU has emerged as a promising framework to protect both the population and habitat health.

Nancy Krieger (2014) introduced the social determinants of health in the bookEcological Urbanism, and she showed that the neighborhoods of Boston affect health differently.

The Moving to Opportunity experiment conducted at Harvard University with 4,600 families showed that providing low-income families with assistance to move to better neighborhoods greatly improved the mental and physical health of children and adults (Ludwig et al., 2013; Chetty et al., 2015). If EU could reduce the socioeconomic disparities in a city, it would greatly benefit the health of urban populations in LA. Moreover, there are other forms in which EU can benefit human health. Some of the city-level polices to reduce greenhouse gas (GHG) emissions entail net benefits to human health (Watts et al., 2015).

Usually, different ecological approaches have argued against anthropocentrism because it has resulted in the unsustainable exploitation of nature resources and the related severe impacts on natural ecosystems. However, humans are not only aggressors but also victims, particularly regarding their own health. In Brazil, despite its effectiveness, the body of laws and regulations protecting ecosystems and biodiversity are robust, but the implications for the health of human beings due to changes in city environments are frequently neglected. While a new urban enterprise undergoes a strict environmental impact evaluation before being approved, possible health impacts, such as the adverse effects of noise and local air pollution exposure owing to changes in road use, are barely evaluated (Saldiva, 2010). It is important to emphasize that an ecological approach does not contrast with a human health approach

The five domains we discuss in this paper are somewhat related to mental health, but considering the increased concern about mental illness in city environments, we will underscore some of these relationships. Although the potential influence of individual characteristics on mental health status is well recognized (WHO, 2014a), less is known about the association between features of the context in which an individual lives and their mental health (Weich et al., 2001). Studies have shown that greater socio-economic disadvantage, a poorer physical and social environment, and higher levels of crime are stressors that can lead to mental illness (Galea et al., 2011). A meta-analysiscombined data from 16 countries and concluded that psychiatric disorders are more prevalent in urban areas - a 1.39 times higher risk than in rural settlements (Peen et al., 2010). Mental and neurological disorders account for almost one quarter of the total burden of disease in LA and the Caribbean (PAHO, 2013). Rising levels of violence and mental illness in LA require integrated actions at the government level, as well as in health institutions, society, and other sectors (Harpham, 2009). Urban settlements could shape mental health for the better by reducing social deprivation and violence through the devices discussed in this paper (e.g., community gardens).

In this paper, we first briefly describe the historical links between health and urban planning. Next, we propose a discussion based on the five thematic areas proposed by Rydin et al. (2012): a) transportation, mobility, and physical activity; b) urban food production; c) urban heat islands; d) thermal comfort and indoor air quality; and e) sanitation and wastewater management. At the end of the paper, we present our final considerations, including further directions for research.

\section{Urban planning and health: a historical overview}

Public health and urban planning emerged with the common goal of reducing the harmful health effects of rapid industrialization and urbanization. Both fields were particularly concerned with preventing urban outbreaks of infectious disease (Corburn, 2004).

The first infrastructure improvements to promote better health in the early 19 th century relied on miasma theory, which was the belief that diseases are caused by noxious substances present in bad-smelling air: This theory enhanced public concern with sanitation and hygiene. Engineering-based measures, such as sewers and garbage collection, contributed to containing disease in urban settlements. However; the great sanitary awakening came in the late $19^{\text {th }}$ century, when the association between microorganisms and particular diseases were widely accepted, i.e., germ theory. Public health began to devise specific strategies for controlling and preventing specific diseases, based on laboratory identification of the 


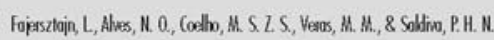

cause of the disease. At the same time, the public responsibility for health began to include not only environmental sanitation, but also individual health. Developing nations followed this trend, but they started the sanitary shift a few decades later, by the middle of the 20th century (Rydin et al., 2012) However, even now, sanitary facilities have not reached the entire urban population of LA, particularly the residents of slums, who are estimated to number 110 million people (FAO, 2014). In Sao Paulo, Brazil, the sanitary awakening started in the late 19th century, marked by the foundation of a company to supply residential water However, sewage did not receive the same attention. The first law to regulate water pollution in the region was passed in 1940, and until today the sewage treatment rate for the state of Sao Paulo (of which the city of Sao Paulo is the capital) is $53,34 \%$ (Brasil, 2014). Access to health care facilities has played an important role in improving health outcomes in cities (Merzel, 2000), but they are not discussed in this paper:

During the sanitary reform, zoning in countries such as the United States embodied the concept of isolating urban populations from the undesirable externalities of the economy, and it separated the population from areas strictly designated for functions considered unhealthy, e.g., industry (Corburn, 2004) This model probably inspired some LA cities, but their major challenge has been unplanned growth and the continued expansion of slums and substandard housing. Basic urban infrastructure was not implemented at the same pace of the rapid growth of the urban population seen in LA.

Subsequently, urban planning and health aims moved in different directions. The main focus of city planning became enhancing economic outcomes Public health focused on modifying individual risk factors (e.g., diet, exercise, and smoking), with successful outcomes. However, the health sector largely neglected the social dimensions of disease (Corburn, 2004), restricting the reach of health gains to selected populations.

Over the past few decades, the World Health Organization (WHO) has attempted to increase the overlaps between health and urban planning by two strategies - health in all polices (Ollila, 2011) and the healthy cities movement (Rydin et al., 2012) - but they are not yet robust in LA cities.
Recently, the health community has been concerned about the health impacts of climate change also increasing. In 2009, a series of papers published by The Lancet suggested that actions to reduce GHG emissions often, although not always, entail net benefits for health locally (Haines et al., 2009). This year, the same journal reported that tackling climate change could be the greatest global health opportunity of the 21st century (Dora et al., 2015; Watts et al., 2015) Because lower income populations are more vulnerable to climate change impacts on all scales, not only in comparing nations, but also within the same city, tackling climate change is an opportunity to reduce health inequalities. The EU approach discussed by Mostafavi \& Doherty (2014), in their book that inspired this publication, is a golden opportunity to reinforce the links between public health and urban planning in LA cities, as well as links with the environment.

Building and maintaining cities that shape their residents' health for better are not simple tasks. According to the United Nations, $75.8 \%$ of the LA population live in 198 large cities, and $23 \%$ of urban residents live in slums without access to basic services, such as housing, clean water, and sanitation. Cities are complex systems, and WHO has recommended the use of trial and error in local projects to increase understanding of how best to improve urban health outcomes in specific contexts (Rydin et al., 2012). Hence, communication between city planners and the health sector should be improved and maintained, and this paper makes a contribution to the health discipline. To address this trial and error recommendation, we provide a broad variety of local examples.

In general, chronic non-transmissible diseases prevail in cities and are modified by them. The LA challenge is to face this modern pattern of diseases in highly urbanized regions, along with infectious diseases and widespread health inequality issues The collaborative work between the health sector and urban planners might result in a considerable health gain for the region, particularly if planners focus on strategies to reduce the health inequalities within cities.

Historically, controlling the environment through technology (engineering-based measures) was the main concept driving the cooperation between the public health and urban planning fields, first through sanitary-based measures and then using a more sustainable design. Currently, architects and urban

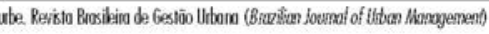


planners seek alternative design approaches to address the whole infrastructure of cities in the EU. Some high income cities follow each step of this process. LA cities follow more flexible pathways because some of these cities are already implementing an EU approach, but they continue to struggle with poor sewage drainage and low-efficiency buildings.

\section{Transportation, mobility, and physical activity}

According to the WHO, transportation is one of the social determinants of health. However, its health aspects are not routinely addressed during the formulation and planning of urban transport polices in many LA cities (WHO, 2011).

The flow of goods and people within and through cities can negatively affect the health of people, the environment, and the economy. Therefore, there is an urgent need to improve transport in cities to address time and air pollutant emissions

Currently, the urban environment in LA is frequently characterized by industrialization and environmental deterioration, as well as crowded cities surrounded by peri-urban poverty, traffic congestion, and few or low quality (comfort and time spending) public transportation options. The prevalent mode of transportation in cities is private cars. Moreover having a car is synonymous with mobility, comfort, and status (Newman \& Kenworthy, 1999). However; this mode of transportation results in serious health and environmental problems. Cars restrict physical exertion, contribute to isolation from social interaction and stress, and result in loss of hours from work and leisure due to time spent in traffic. Furthermore, cars contribute to air and noise pollution, negatively influencing health (Rissel, 2009). Additionally, car accidents kill thousands of people every year (Fletcher \& McMichael, 1996 apud McMichael, 1996)

Hundreds of scientific studies have shown how transportation options can improve health status, prevent sedentarism-related diseases and mitigate harmful environmental impacts (e.g., greenhouse gases emission and urban air pollution). Environment-friendly and healthy alternatives include walking, cycling, and the use of public transportation. However, these alternatives must be safe, comfortable, accessible, inexpensive, convenient, efficient, and integrated to cover the whole city to stimulate their use, thus constituting a challenge for urban planners
In Europe, strategies to create cycle networks and integration between cycling and public transportation have been successful, stimulating the use of active transport with significant environmental and health gains (Pucher \& Buehler; 2008, 2007)

A recent systematic review of the health impacts of active transportation, conducted by Mueller et al. (2015), emphasized that active transport provides health benefits despite the risks of traffic accidents and exposure to air pollution, which are outweighed by the positive outcomes. Active forms of transportation are linked to increased physical activity and social interaction. Physical activity can improve the health status of an individual and can reduce the risk of developing several diseases, e.g., type 2 diabetes, hypertension, and obesity. Nevertheless, more than $30 \%$ of adults worldwide perform insufficient physical activity. Moreover, insufficient physical activity, together with a high-energy diet, is one of the causes of obesity. Active modes of travel can reduce the number of cars on the streets, thus benefiting the health by reducing air pollution.

Unlike in Europe and North America, fewer cities in LA have introduced active transportation initiatives. The recent review conducted by Moeller and colleagues did not find studies conducted in LA, but the authors excluded studies in Spanish and Portuguese Language. A search in the PubMed database (using the keywords "active transportation" and "physical activity") yielded 736 results but only four when the keyword "Latin America" was added. Moreover, only one (Becerra et al., 2013) study was in fact on the topic. According to Becerra and colleagues, the appeal for active transportation in LA is based on reducing traffic congestion and not on the environmental and health benefits of these strategies (Becerra et al., 2013). Ideally, both the health and environmental sectors should participate in the decision-making process, and urban planners should be aware of the impacts of a built environment and transportation modes on health.

In contrast, the Web sites of South American cities depict initiatives in Sao Paulo, Rio de Janeiro, Curitiba, Bogotá, Buenos Aires, and Santiago. The World Bank has also published reports on the successful implementation of BRT (bus-based rapid transit) systems in different countries (e.g., Ecuador Mexico). Initiatives that stimulate active transport also include the construction of exclusive bike lanes 
and the closure of streets to motorized traffic during the weekends and on holidays for cycling, running, and walking. Evaluation of the health benefits of these initiatives has been rare, and the methods to estimate or predict their health impacts are not precise. Laverty et al. (2015) examined the correlations among socio-demographic status, the use of active travel, and specific health outcomes (adiposity, diabetes, blood pressure) in adults (mean age: 58 years old) from six middle-income countries: Mexico, China, India, South Africa, Russia, and Ghana. They found that people who use more active modes of transport presented a reduced risk of being overweight and lower systolic blood pressure and BMI (body mass index). Saunders etal. (2013) noted that active travel could have positive effects on health outcomes but not specifically on obesity.

Thus, active transportation not only reduces urban traffic, air pollution, and climate-associated changes, but it also improves the health status of people. The benefits rely on healthy increases in physical activity and social interaction, and on reducing the levels of air-pollutant exposure in urban areas, which constitutes a major environmental risk factor for cardiovascular disease and lung cancer. The only way to reduce air pollution exposure is to reduce ambient levels, which requires reducing the emission of pollutants. According to the WHO (2014b), in 2012, there were 58,000 premature deaths in LA due to air pollution exposure.

Vehicle fleets contribute the most to GHG emissions and therefore to climate change, as well as increased mortality owing to extreme temperatures. The impact of temperature on health will be discussed in the "Urban heat islands" section of this paper:

Active transport integrated into an efficient public transportation system is an alternative to improve human health, reduce environmental pollution, and mitigate climate change. The challenge that urban planners and policy makers face today in developing counties is how to implement these changes in previously built urban environments designed to favor the private car mode of transport and to attract users.

\section{Urban food production}

Despite the widespread notion of food production as an exclusively rural activity, the growing of plants and raising of animals within and around cities (FAO,
2014) are not new occurrences. Food insecurity due to poverty (Zezza \& Tasciotti, 2010; Wolch et al., 2014), war (Milburn \& Vail, 2010; Rydin et al., 2012), and natural disasters (Hara et al., 2013) has assured the occurrence of the activity in past decades. At present, UPA (Urban and Peri-urban Agriculture) is also reemerging in the more sustainable cities of developed nations (Middle et al., 2014; Hara et al., 2013; Rydin et al., 2012)

It is not possible to project that UPA will replace traditional forms of feeding in highly populated cities, but the potentialbenefits for ecology and human health cannot be ignored. The WHO appealed to cities and their governments to incorporate food policies into urban plans (Rydin et al., 2012).

UPA is widespread in LA. In Rosario, Argentina, 1.35 million inhabitants have 800 community gardens producing vegetables for 40,000 people (FA0, 2014). In Mexico City, nearly 23 thousand ha of land are dedicated to crop production, and in Cuba agriculture is practiced by 40 thousand urban workers on an estimated area of 33,500 ha (FA0, 2014).

The benefits of urban food production range from improvements in health and social outcomes to environmental and economic benefits. UPA is good for health because it improves human nutrition. Compared with other urban dwellers, urban producer families have more diverse diets and consume more vegetables and fruits (FAO, 2014). Low ingestion of vegetables and fruits is a major risk factor for the global burden of disease (Lim et al., 2012). In LA and the Caribbean, low intake of whole grains and other nutrition-related risks are also among the top ten major risk factors for disease. Better nutrition benefits cardiovascular health (Hu et al., 2001) and helps to combat other non-communicable diseases, such as obesity (Gatto et al., 2015) and diabetes (Tohill et al., 2004). UPA also creates opportunities for physical activity, reinforcing the described health gains (Rydin et al., 2012). Furthermore, engaging in urban food production potentially enhances emotional health through stress reduction and socialization. Along with improving access to quality food, UPA has proved to be an important response to anticipated food shortages due to natural disasters, droughts, and increases in food prices, among other situations (Hara et al., 2013; Rydin et al., 2012; Angnotti, 2015).

The services to the ecosystem from agriculture include the regulation of water and climate systems,

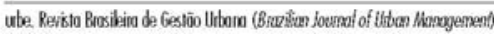


maintenance of soil fertility, and the regulation of pollination, among others (Swinton et al., 2007). When food is locally produced, there is a reduction in transportation demand, resulting in energy savings and a decrease in the emissions of air pollutants (Angnotti, 2015; Hara et al., 2013), all of which are ecological gains. Other potential gains include reduction in solid waste exporting due to composting projects (FAO, 2014) and better management of rainwater through wider urban green coverage, which also allows for groundwater restoration (Angnotti, 2015)

UPA contributes to economic growth through employment and other forms of income generation because families engaged in UPA reduce their spending on food and earn additional income from sales (FAO, 2014). Revitalization of low-income communities (Angnotti, 2015) and the raising of the value of local housing due to the amelioration of landscape aesthetics (Rydin et al., 2012) might emerge as indirect social and economic gains. Security is enhanced by greater civic involvement and the presence of more people outside in yards and gardens (Rydin et al., 2012), which also promote social cohesion (FAO, 2014).

The agro-ecological approach enhances environmental and nutritional gains (Baranski et al., 2014) and perfectly suits EU values because both concepts share integrative views of environmental sustainability. Furthermore, the agro-ecological approach might be cost-effective in specific settings. In Havana, producing 1 million tons of vegetables via organic agriculture is US\$39.5 million less expensive than conventional agriculture (FAO, 2014).

Despite its particular challenges, the city is an appropriate venue for integrating food production with other ecosystem services (FAO, 2014). Even in densely populated areas, food can be produced in containers on rooftops and balconies, in parks and elsewhere. It is important to note that food production in the city is possible, but replacing the current forms of food supply to feed cities is not yet possible, and it is not currently a goal at all. UPA should ideally occur alongside the current forms of food supply, and EU might be an appropriate approach for UPA and other forms of food supply to cities coexisting.

The dominant form of urban food production in LA is backyard family horticulture and school gardens, but the region also has other forms of community and commercial gardens. UPA production includes the farming of vegetables, fruits, and cereals, the raising of small animals for eggs and meat, and the growing of flowers. All age groups and walks of life are engaged in these activities, but most of them come from low-income households. Women are the more prevalent gender, particularly in the Caribbean, Bolivia, Colombia, Ecuador, Honduras, and Nicaragua (FAO, 2014). In El Alto, Bolivia, a gardening project taught more than one thousand families production techniques adapted to the city's agro-climatic conditions. The result is that, in one year, a typical family produces nearly 1 ton of tomatoes, saves US\$60 a month on food purchases, and earns US\$15 from the sale of surpluses (FA0, 2014).

UPA is under increasing pressure from urbanization itself. A major issue is the lack of space, resulting in the high cost of land and competitive use. In the peri-urban area of Rosario, Argentina, soybeans for export have displaced other traditional produce for the domestic market, such as wheat, sunflowers, milk, and fruit. In Mexico City and Lima, slums and industrial activity have been impairing water quality and availability for agriculture use (FAO, 2014). Technical issues can be overcome, but most cities must still face the lack of quality seed, the poor quality of soils, and the unreliability of water supplies (FAO, 2014). There is also the need to overcome UPA-related trade issues, including the high cost of inputs and the unavailability of credit to buy tools and processing equipment; very limited access to markets is also a major issue (FA0, 2014; Angnotti, 2015). Moreover; the overuse of agrochemicals exposes some small farmers to health risks and impairs environmental quality, polluting water supplies and other natural resources (FA0, 2014).

Finally, we draw attention to the role of contaminated soil in urban areas, which often contains dangerous levels of heavy metals (Cheng etal., 2011; Ferri et al., 2015). Heavy metals are present in the soil of many urban vegetable gardens in the United States and Europe (Clarket al., 2008; Cheng et al., 2011; Burt et al., 2014; Ferri, et al., 2015), prompting questions about the potential health consequences of UPA in contaminated areas.

Lead and other heavy metals have been strongly linked to severe cognitive, motor and behavioral disorders in children (Grandjean \& Landrigan, 2006). Researchers agree that the exposure routes for humans occur through accidental ingestion of the soil and inhaling of contaminated dust (Kessler, 2013), posing 
risks to farmers, particularly children. There is less consensus about the health effects of the consumption of crops grown in contaminated soil (Warming etal., 2015; Ferri et al., 2015; Augustsson et al., 2015), probably due to the general lack of studies, particularly in LA. The broad range of variables involved - soil constitution, type of pollutant, type of crop - has impaired comparisons between studies. Hence, the most prudent attitude is to follow the specific management practices for urban gardeners (Kessler, 2013), which can help to prevent these harmful exposures. Some of these recommendations are closely related to urban planners' activities, such as building gardens away from existing roads.

More successful UPA in LA cities has received technical support from international organizations and/or NGOs. Political will has also played a role. Cities where local UPA was successful also inspired national policies, spreading UPA across the country, as occurred in Nicaragua and Honduras (FA0, 2014).

Enhancing UPA requires support from all levels of government because it should be integrated with activities from different levels of governance, such as solid waste management, water supply, and education. In LA, 12 countries have implemented national policies promoting UPA (FAO, 2014).

Many LA cities use composting for urban organic waste fertilizer (FAO, 2014). The region also has experience in better managing of water, storing rainwater, reusing resources, and using technologies that conserve water. In El Alto, new technologies have reduced by $80 \%$ the need for water by crops (FAO, 2014). There has also been successful experience with converting pig manure into biogas and selling the energy to urban residents (FAO, 2014). In general, all schools, parks, and community facilities are candidates for composting projects and for growing food (Angnotti, 2015)

Zoning urban areas for agriculture can protect against competition with other land uses and can facilitate the recognition of UPA as an economic activity. However; zoning usually neglects UPA (Rydin et al., 2012); only three nations in LA have explicitly included it in their occupation planning (FAO, 2014). Furthermore, protecting sustainable agriculture by small-scale farmers in peri-urban agriculture by law could safeguard water reservoirs (FA0, 2014).

Before choosing an area for UPA, it is recommended that the local conditions (soil, light incidence, water supply, etc.) be evaluated. In the absence of contaminant tests (the gold standard), the local history of urbanization and industrialization has indirectly addressed the potential contamination of the soil. In cases of previous industrial activities, gas stations, and laundry services, it is prudent to consider the soil contaminated. Remediation is frequently possible, but the unavailability of specialized services at some sites and the high costs might be impediments. Building raised beds and importing healthy soil are alternatives (Rydin et al., 2012; Angnotti, 2015; Kessler, 2013). Kessler (2013) summarized the best management practices for urban gardeners, including agricultural practices (e.g., covering existing soil and walkways with mulch) and good habits (e.g., wearing gloves)

Financial-related mechanisms, such as heavily taxing vacant land and providing credits for urban farming, can play key roles in overcoming the high cost of land (Angnotti, 2015).

Architects and designers have already developed solutions to cope with the lack of space for activity; vertical farms, including rooftop crops, are an example (Torreggiani et al., 2012)

Specific polices can address technical issues with UPA, such as lack of quality seed, poor quality of soils, and the unreliability of water supplies. The same is true for trade-related issues, such as the high cost of inputs, the unavailability of credit for equipment, and lack of access to markets. Experiences in LA have shown that trading production with schools and hospitals and promoting technologies that add value to UPA production enhance the activity. In Antigua and Barbuda, fruit drinks and sun-dried hot peppers from backyard gardens are improving the financial gains of gardeners (FAO, 2014)

Occupational health risks owing to the overuse of agrochemicals can be prevented by the agro-ecological approach, which is also aligned with ecological values. In some countries, the use of synthetic pesticides and fertilizers is forbidden by law.

Finally, urban planners and designers can incorporate UPA concepts while planning new buildings and cities. In China, some buildings have been planned with level rooftop surfaces that can be used for farming. The arrangement improves the solar angle for natural lighting within apartment buildings, as well as natural cross-ventilation (Rydin et al., 2012). 
Urban heat island

The accelerated urbanization rate is changing the landscape and soil coverage. Buildings, roads, and other infrastructure have replaced land and vegetation, resulting in elevated temperatures in urban areas, compared to their outlying rural surroundings, which is a phenomenon known as urban heat islands (Berdahl \& Bretz, 1997; Sobral, 2005).

The magnitude of surface Urban Heat Islands (UHIs) varies by the season, due to changes in the sun's intensity, ground cover, and weather: Atmospheric UHIs are often weak during the late morning and throughout the day and become more pronounced after sunset due to the slow release of heat from the urban infrastructure. The timing of this peak depends on the properties of urban and rural surfaces, the season, and prevailing weather conditions (Akbari, 2005). Increased daytime surface temperatures, reduced nighttime cooling, and higher air pollution levels associated with UHIs can affect human health by contributing to general discomfort, respiratory difficulties, heat cramps and exhaustion, non-fatal heat stroke, and heat-related mortality. UHI can also exacerbate the impact of heat waves, which are periods of abnormal heat. Sensitive people, children, the elderly, and those with chronic diseases are at major risk. The Centers for Disease Control and Prevention estimated that, from 1979 to 1999 , excessive heat exposure contributed to more than 8,000 premature deaths in the United States (CDC, 2004).

Urban pollution contributes to complex atmospheric processes (Akbari, 2005; EPA, 2006); hence, the emission of pollutant gases must be considered when analyzing the meteorological variables of large cities (Coelho et al., 2010).

In Sao Paulo, the thermal gradient between the outskirts and the central zone can reach $10^{\circ} \mathrm{C}$. The reduction of green coverage, the increased use of fossil fuels, and the construction of high buildings that act as ventilation barriers can explain UHIs (Sobral, 2005). In addition, modifications of the urban thermal profile affect sensible heat, latent heat and momentum fluxes, surface convergence, optical properties of the atmosphere, boundary-layer height, and other boundary-layer features. Such changes impact pollution dispersion, thunderstorm initiation, and many other physical and chemical processes in the urban environment (Khan \& Simpson, 2001).
Despite the broad variety of meteorological systems that affect Sao Paulo, the city presents two well-defined seasons: Spring-Summer (hot and wet) and Fall-Winter (cold and dry) (CDC, 2004), but extreme weather events intensified by climate change are becoming more frequent (Bornstein \& Lin, 2000). In winter; pollutant concentrations can be critical because of the low availability of solar energy, limiting the development of the planetary boundary layer: Hence, pollution dispersion is heavily dependent on the strength of the heat island circulation (Bornstein \& Lin, 2000). The health consequences are increasing hospital admissions due to cardiorespiratory diseases (Coelho et al., 2010; Braga et al., 2002; Saldiva et al., 1992), and sometimes death (WHO, 2004). UHIs also increase ground-level formation of ozone, which is a pollutant related to acute asth ma crises (Andrade et al., 2004). Nitrogen and volatile organic compounds, which are released from fossil fuel combustion, react in the presence of sunlight, forming ozone, particularly during the high temperature periods of late spring and early autumn (Hsieh et al., 1999; Andrade et al., 2004). Further, the temperature gradient between central (hot) and peripheral areas (less hot) of the city from UHIs increase heavy rain events in the central part of the city (Freitas et al., 2007). Urban effects can be particularly important for explaining the daily rainfall extremes in the summer (Silva Dias et al., 2013), leading to floods and associated health problems (leptospirosis infections).

Thermal pollution can aggravate respiratory and cardiovascular diseases (WHO, 2004; Guo et al., 2014; Laschewski \& Jendritzky, 2002), and it is associated with discomfort and physiological stress. The thermal comfort neutrality range falls between $17^{\circ} \mathrm{C}$ and $31^{\circ} \mathrm{C}$. Above that temperature, hypotension, hyperthermia, tachycardia, heart failure, poor appetite, dehydration, fatigue, irritability, decreased learning ability, impaired memory, and depression may occur: An increase in air temperature also impacts flora and fauna, influencing the distribution of vector-borne diseases, such as dengue fever (Coelho \& Massad, 2012; Laschewski \& Jendritzky, 2002).

Moreover, changes in meteorological parameters in large cities due to urbanization and global warming have affected weather in these places. As a result, heat waves, dry weather, and rain are very likely to increase in both frequency and intensity. In urban regions, these future heat waves will be exacerbated by the UHI effect 
and will have the potential to influence negatively the health and welfare of residents. In Shanghai, China, a study showed that UHIs are directly responsible for adverse health effects due to exposure to extreme thermal conditions (Tan et al., 2010). Socioeconomic factors modulate the health burden of temperature extremes (Urban et al., 2014; Burkart et al., 2011). Temperature and mortality are usually associated. In England and Wales, a study analyzed 10 areas during the summer from 1993 to 2006 , and heat was associated with increased mortality in nearly all causes of death in the elderly (Gasparrini et al., 2012).

Weather event extremes present a significant health risk, and the hazard is likely to escalate with the increased future temperatures presently predicted by climate change models. The impact of heatwaves is often stronger in densely populated cities and where the climate is involuntarily modified to produce an UHI effect.

Humans have mechanisms for managing additional heat and cold, but overcoming this vital threshold can lead to serious health conditions. A recent study published in The Lancet with 384 locations in 13 counties revealed that uncomfortable ambient temperature is responsible for considerable increases in mortality, with significant differences between countries. According to the results, the temperature is responsible for increasing a considerable proportion of deaths to $7.71 \%(95 \% \mathrm{Cl} 7.43-7.91)$. Nevertheless, there are significant inter-country variations in attributable risk (for both hot and cold), with the uppermost attributable risk in Italy, China, and Japan and the lowermost estimates in Thailand, Brazil, and Sweden (Gasparrini et al., 2015)

Health impacts and vulnerability due to extreme weather events require systematic approaches and integrated policy and planning responses from a range of government agencies. Unfortunately, effective mitigation actions are almost non-existent in Brazil. According to Marengo etal. (2009), by 2100, the average temperature may have risen between $2{ }^{\circ} \mathrm{C}$ and $4{ }^{\circ} \mathrm{C}$ in Brazil, compared with the average temperatures recorded between 1961 and 1990. Thermal discomfort conditions will affect thousands of people. There will likely be an increase in the number and severity of cases of heart disease, asthma and infections. At a higher level of severity, individuals who use medication chronically to control respiratory and heart diseases will require higher doses to control their illnesses to cope with environmental changes. Increased susceptibility to pollutants and climatic factors is dependent on individual, environmental and socioeconomic factors and on housing conditions (Souza \& Macedo, 2010)

In contrast, developed countries have implemented significant mitigation policies in urban planning, with a focus on sustainability and energy but that indirectly have co-benefits to health. For example, Green Infrastructure (GI) has contributed to the mitigation of UHIs. In the context of climate change, with the expected increase in temperature, the dryness and intensity of heat waves, and storms and floods, green areas assume even greater importance because they can create a cooling effect that extends to surrounding areas.

The project of the Urbanism, Climate Adaptation and Health Cluster, funded by the CSIRO Climate Adaptation Flagship, focuses on improving understanding of the interactions between climate and health in urban areas in Australia, using green infrastructure (GI) to address high temperatures and dry humidity (CRC, 2012).

A European commission has produced guides to assist authorities and stakeholders in investing in Green Infrastructure (GI) through the Cohesion Fund for 2014-2020. The first is a guide to "multi-benefit cohesion policy investments in nature and green infrastructure" (European Commission, 2015).

Seven federal agencies have united to support the Green Infrastructure Collaborative in the United States of America. These agencies signed a Federal Letter of Support committing to specific actions to promote green infrastructure. The cooperating agencies are the EPA, the Department of Housing and Urban Development, the Department of Transportation, the Department of Agriculture, the Department of the Interior, the Department of Defense, and the Department of Energy (EPA, 2014)

Implementation of UHI mitigation strategies, such as increased vegetative cover and higher-albedo surface materials, was suggested by studies performed in New Jersey addressing issues such as economic efficiency and the reduction of energy consumption and costs at the sites (Solecki et al., 2005). Urban food production, previously discussed in this paper, might be an option for vegetative cover: 
Finally, interventions can be implemented at various levels: urban planning, with the implementation of climate controlling factors, such as afforestation, squares, streets, policies to decrease emissions from pollutants, etc.; and housing, with improvements in the constructive conditions that favor thermal insulation to protect residents (more information in the "Thermal comfort and indoor air quality" section).

A third level of intervention is education: educational campaigns and awareness of the adverse effects of weather and orientation of attitudes could facilitate protection against cold/heat or pollution (Sobral, 2005; CDC, 2004)

\section{Thermal comfort and indoor air quality}

Urban planners, architects, and designers can help to assure better indoor quality and thermal comfort for urban inhabitants at home, work, school or other facilities. The major challenge will be how to improve indoor environments for the 110 million slum dwellers in LA (2010) (FAO, 2014)

Indoor air pollution is among the top risk factors for chronic diseases in LA (Lim et al., 2012), and it was responsible for $7 \%$ of the premature deaths in the region (WHO, 2014b) in 2010. Indoor air quality is modulated by air exchange, outdoor pollutant levels, and the production of indoor pollutants (Rydin et al., 2012). Architects are in the position to improve air exchange and consequently indoor air quality.

The burning of solid fuels for cooking and heating is the most studied source of indoor air pollution. The impacts on health include increased risks of pneumonia in children ( $<5$ years old) and of chronic obstructive pulmonary disease, cardiovasculardisease, cataracts, and lung cancer in adults (Smith et al., 2013). Women and small children are the most vulnerable because they spend the most time in or near the kitchen. The lack of access to clean energy sources can also result in other health risks, such as burns, injuries, intoxication, and violence against women while they collect fuel (Dora et al., 2015).

In Brazil, the highest percentage of a population in a metropolitan region without a stove at home was $1.76 \%$ in Fortaleza (IBGE, 2011). However, this percentage could be significantly higher in the less-developed countries of LA (Laborde et al., 2015) More efficient biomass stoves (ideally attaining nearly complete combustion) have been a successful solution. In Guatemala, child pneumonia decreased by half in houses that successfully $(90 \%$ reduction in the levels of indoor air pollutants) installed wood stoves with chimneys (Smith et al., 2011). Additionally, improved cooking stoves reduce GHG emissions, both benefiting public health and mitigating climate change (Wilkinson et al., 2009). Affordable household electricity would also result in better indoor air quality because the use of gas or electricity to cook creates little or no pollution in the kitchen (Smith et al., 2013). However, improving household ventilation is an important mitigation strategy, and architects and designers must be aware of it.

Similarly, improved insulation, efficiency of heating and the use of other building materials that reduce heat losses through the walls, windows, and roof are among the successful strategies to reduce energy use (Rydin et al., 2012)

Warmth and energy efficiency interventions can improve general health, particularly in people with previous chronic respiratory diseases (Thomson et al., 2013). Furthermore, thermal comfort strategies are likely to improve cardiovascular health because low indoor temperature is associated with a higher risk of high blood pressure (Shiue \& Shiue, 2014)

Indoor tobacco smoke is also a recognized source of indoor air pollutants (Laumbach \& Kipen, 2014). Restricting smoking indoors is an effective police for reducing exposure (Sebrié et al., 2008), but it is probably beyond the abilities of urban planners. However, improving ventilation can also help mitigate exposure to indoor tobacco smoke.

Asbestos is a carcinogenic substance (IARC, 2009) related to a wide variety of lung diseases ( $O$ 'Reilly et al., 2007), including asbestosis, a disease caused by the inhalation of asbestos (Bledsoe et al., 2014). Due to its insulating, fire-resisting and sound-absorbing properties, asbestos was usually mixed with cement for building construction materials, particularly roofing products (Haynes, 2010). Asbestos is virtually banned in most developed countries (Laborde et al., 2015). In LA, Argentina, Chile, Uruguay and Honduras have also banned asbestos (Laborde et al., 2015). In the other countries, if possible, architects and designers should avoid using building materials with asbestos and other noxious compounds (e.g., formaldehyde) in their composition to improve indoor air quality (Wang \& Zhang, 2009). 


\section{Sanitation and wastewater management}

Safe drinking water access and sanitation are basic human rights (UN, 2010). There is widespread understanding that the lack of access to safe drinking water, sanitation, and hygiene affects human health (WHO/UNICEF, 2014), particularly causing diarrheal outbreaks. Malnutrition, vector-born disease (e.g., dengue fever), neglected tropical diseases (e.g., schistosomiasis), and non-communicable disease risks related to chemical contaminants are recognized health outcomes (Freeman et al., 2013; Bartram etal., 2005). Poor people are at greater risk because their access to improved water sources and sanitation is restricted (Dora et al., 2015)

In LA and the Caribbean, the access to safe drinking water reached $94 \%$ of the population in 2012. The lowest levels of coverage were found in the Dominican Republic, Ecuador, Haiti, Nicaragua and Peru, ranging from 76\% to $90 \%$ (WHO/UNICEF, 2014).

The scenario is worse for improved sanitation facilities. In 2012,110 million people in the region still lacked access to sanitation, despite improvements in previous years (WHO/UNICEF, 2014). One explanation is that investment in infrastructure to supply water tends to be seen as a priority by politicians and citizens, whereas the disposal of human excreta is comparatively neglected (Rydin et al., 2012).

According to the WHO/UNIFEC Joint Monitoring Program for Water Supply and Sanitation, an improved drinking-water source is protected from outside contamination, in particular from contamination with fecal matter, and should include: piped water into dwellings; piped water to yards/plots; public taps or standpipes; tubewells or boreholes; protected dug wells; protected springs; and rainwater (WHO/UNICEF /JMP). An improved sanitation facility is one that hygienically separates human excreta from human contact: flush toilets, piped sewer systems, septic tanks, flushing/pouring to pit latrines, ventilated improved pit latrines, pit latrines with slabs and composting toilets. Flushing/pouring to outside, pit latrines without slabs, buckets, hanging toilets or hanging latrine, and a lack of facilities or bushes or fields are classified as unimproved sanitation facilities (WHO/UNICEF, 2015). However, many unimproved systems might be misclassified, (Rydin et al., 2012) and improved drinking water sources might still contain substantial bacterial and chemical contamination (Dora et al., 2015).

In addition, climate change is expected to increase the risk of water shortages in urban areas (Dora et al., 2015), threatening the achievements of water and sanitation facilities. In 2015, the water sources of the city of Sao Paulo decreased drastically, impairing the water supply. At the beginning of the year; the city also faced a severe dengue fever epidemic. Inadequate rainwater collection and water storage are possible causes of the increase in dengue fever cases in 2015.

Ideally, all households should have a potable water supply for internal bathrooms and kitchens, a flushing toilet, and storm drainage to prevent flooding, but in many cities, this set of standards can only be achieved in the wealthiest neighborhoods. Informal settlements are of particular concern (Rydin et al., 2012). In Rio de Janeiro, Brazil, people living in informal settlements (1.39 million people) have less access to adequate water and sanitation, compared with the other residents of the city (Snyder et al., 2014). Urban planning regarding sanitation must focus on reducing unequal access. A major challenge is defining who will pay for it. Usually, city authorities see on-site toilet facilities as the responsibility of individuals. Poor houses in informal settlements are unlikely to have financial capital invested in such facilities, particularly those living in rental properties (Rydin et al., 2012).

A recent report described a step-by-step approach to the complex circumstances surrounding the need to provide sanitation to urban areas, particularly to densely populated areas and to the less affluent sectors of society. It considered financial issues, as well as other dimensions, institutional, environmental, technical and social (Galli et al., 2014).

Considering all of the dimensions, increasing the effectiveness of sanitation measures results in health protection for those that received these facilities. However, if city planners also consider the concepts of ecological urbanism, the environment would also be protected. In addition, the ecological urbanism approach is a tool for integrating the planning of green areas and sanitation, both of which are essential for the environment and human health. The "Urban heat islands" and "Urban food and agriculture" sections discussed some of the wide variety of benefits to green spaces. 


\section{Final considerations}

Ecological and human health gains in city environments are not at odds. Distinguished by its integrated and multi-disciplinary foundation, EU is an opportunity to promote population and habitat health and to reduce health inequalities in LA, a part of the world where $80 \%$ of population lives in cities, $23 \%$ of it in slums.

The empirical evidence discussed in this paper shows that urbanism-related measures can shape human health for better or worse. Experiences from developed (more abundant) and LA cities can inspire the use of trial and error in local projects in LA to increase understanding of how best to improve urban population and habitat health, applying an EU approach in specific urban contexts.

Similar to initiatives that have proposed indicators linking health and sustainability for the post-2015 development agenda, a next step to enhance the links between $\mathrm{EU}$ and population health could be the proposal of health indicators that shape human health for better city environments.

\section{References}

Akbari, H. (2005). Energy saving potentials and air quality benefits of urban heat island mitigation. Berkeley: Lawrence Berkeley National Laboratory. Retrieved in 08 June 2015. from http://www.osti.gov/scitech/servlets/purl/860475

Andrade, M. F., Ynoue, R. Y., Harley, R., \& Miguel, A. H. (2004). Air-quality model simulating photochemical formation of pollutants: the São Paulo Metropolitan Area, Brazil. International Journal of Environment and Pollution, 22(4), 460-475. http://dx.doi.org/10.1504/IJEP.2004.005681

Angnotti, T. (2015). Urban agriculture: long-term strategy or impossible dream? Lessons from Prospect Farm in Brooklyn, New York. Public Health, 129(4), 336-341.

Augustsson, A. L. M., Uddh-Söderberg, T. E., Hogmalm, K. J., \& Filipsson, M. E. M. (2015). Metal uptake by home grown vegetables: the relativeimportancein human health risk assessments at contaminated sites. Environmental Research, 138, 181-190. http://dx.doi.org/10.1016/j. envres.2015.01.020. PMid:25723126.

Baranski, M., Srednicka-Tober, D., Volakakis, N., Seal, C., Sanderson, R.,Stewart, G. B., Benbrook, C., Biavati, B., Markellou,
E., Giotis, C., Gromadzka-Ostrowska, J., Rembiałkowska, E., Skwarło-Sońta, K., Tahvonen, R., Janovská, D., Niggli, U., Nicot, P., \& Leifert, C. (2014). Higher antioxidant and lower cadmium concentrations and lower incidence of pesticide residues in organically grown crops: a systematic literature review and meta-analyses. British Journal of Nutrition, 112(5), 794-811. http://dx.doi.org/10.1017/ S0007114514001366. PMid:24968103.

Bartram, J., Lewis, K., Lenton, R., \& Wright, A. (2005). Focusing on improved water and sanitation for health. Lancet, 365(9461), 810-812. http://dx.doi.org/10.1016/ S0140-6736(05)71007-2. PMid:15733725.

Becerra, J. M., Reis, R. S., Frank, L. D., Ramirez-Marrero, F. A., Welle, B., Cordero, E. A., Paz, F. M., Crespo, C., Dujon, V., Jacoby, E., Dill, J., Weigand, L., \& Padin, C. M. (2013). Transport and health: a look at three Latin American cities. Cadernos de Saude Publica, 29(4), 654-666. http://dx.doi. org/10.1590/S0102-311X2013000800004. PMid:23568296.

Berdahl, P., \& Bretz, S. (1997). Preliminary survey of the solar reflectance of cool roofing materials. Energy and Building, 25(2), 149-158. http://dx.doi.org/10.1016/ S0378-7788(96)01004-3.

Bledsoe, J. R., Christiani, D. C., \& Kradin, R. L. (2014). Smoking-associated fibrosis and pulmonary asbestosis. International Journal of Chronic Obstructive Pulmonary Disease, 10(1), 31-37. http://dx.doi.org/10.2147/COPD. S74643. PMid:25565798.

Bornstein, R., \& Lin, Q. (2000). Urban heat islands and summertime convective thunderstorms in Atlanta: three case studies. Atmospheric Environment, 34(3), 507-516. http://dx.doi.org/10.1016/S1352-2310(99)00374-X.

Braga, A. L. F., Zanobetti, A., \& Schwartz, J. (2002). The effect of weather on respiratory and cardiovascular deaths in 12 U.S. cities. Environmental Health Perspectives, $110(9)$, 859-863, http://dx.doi.org/10.1289/ehp.02110859. PMid:12204818.

Brasil. Ministério das Cidades. Secretaria Nacional de Saneamento Ambiental - SNSA. (2014). Sistema Nacional de Informaçōes sobre Saneamento: diagnóstico dos serviços de água e esgotos: 2013. Brasília: SNSA/MCIDADES. 181 p.

Burkart, K., Schneider, A., Breitner, S., Khan, M. H., Krämer, A., \& Endlicher, W. (2011). The effect of atmospheric thermal conditions and urban thermal pollution on all-cause and cardiovascularmortality in Bangladesh. Environmental Pollution, 159(8-9), 2035-2043. http://dx.doi.org/10.1016/j. envpol.2011.02.005. PMid:21377776. 
Burt, R., Hernandez, L., Shaw, R., Tunstead, R., Ferguson, R., \& Peaslee, S. (2014). Trace element concentration and speciation in selected urban soils in New York City. Environmental Monitoring and Assessment, 186(1), 195215. http://dx.doi.org/10.1007/s10661-013-3366-1. PMid:23943242.

Central of Disease Control - CDC. (2004). Extreme heat: a prevention guide to promote your personal health and safety. Atlanta: CDC. Retrieved in 08 June 2015, from http:// www.bt.cdc.gov/disasters/extremeheat/heat guide.asp

Cheng, Z., Lee, L., Dayan, S., Grinshtein, M., \& Shaw, R. (2011). Speciation of heavy metals in garden soils: evidences from selective and sequential chemical leaching. Soils Sediments, 11(4), 628-638. http://dx.doi.org/10.1007/ s11368-011-0351-6.

Chetty, R., Hendren, N., \& Katz, L. F. (2015). The effects of exposure to better neighborhoods on children: new evidence from the moving to opportunity experiment. American Economic Review. Retrieved in 08 June 2015, from http://scholar.harvard.edu/hendren/publications/ effects-Exposure-Better-Neighborhoods-Children-NewEvidence-Moving-Opportunity.

Clark, H. F., Hausladen, D. M., \& Brabander, D. J. (2008). Urban gardens: Lead exposure, recontamination mechanisms, and implications for remediation design. Environmental Research, 107(3), 312-319. http://dx.doi.org/10.1016/j. envres.2008.03.003. PMid:18456252.

Coelho, M. S. Z. S., \& Massad, E. (2012). The impact of climate on Leptospirosis in São Paulo, Brazil. International Journal of Biometeorology, 56(2), 233-241. http://dx.doi. org/10.1007/s00484-011-0419-4. PMid:21369729.

Coelho, M. S. Z. S., Gonçalves, F. L. T., \& Latorre, M. R. D. O. (2010). Statistical analysis aiming at predicting respiratory tract disease hospital admissions from environmental variables in the city of São Paulo. Journal of Environmental and Public Health, 2010, 1-11. http:// dx.doi.org/10.1155/2010/209270. PMid:20706674.

Corburn, J. (2004). Confronting the challenges in reconnect ing urban planning and public health. American Journal of Public Health, 94(4), 541-546. http://dx.doi.org/10.2105/ AJPH.94.4.541. PMid:15053998.

CRC for water sensitive cities. (2012). Project B3: water sensitive urban design and urban micro-climate. Clayton: CRC. Retrieved in 16 august 2015, from watersensitivecities. org.au
Doll, R., \& Hill, B. (1954). The mortality of doctors in relation to their smooking habits. British Medical Journal, 1(4877), 1451-1455.

Dora, C., Haines, A., Balbus, J., Fletcher, E., Adair-Rohani, H., Alabaster, G., Hossain, R., de Onis, M., Branca, F., \& Neira, M. (2015). Indicators linking health and sustainability in the post-2015 development agenda. Lancet, 385(9965), 380391. http://dx.doi.org/10.1016/S0140-6736(14)60605-X. PMid:24923529.

European Commission. (2015). Building a green for Europe environment infrastructure for Europe. Retrieved in 06 August 2015, from http://ec.europa.eu/environment/ nature/ecosystems/docs/green_infrastructure_broc.pdf

Fajersztajn, L., Veras, M., Barrozo, L. V., \& Saldiva, P. (2013). Air pollution: a potentially modifiable risk factor for lung cancer. Nature Reviews Cancer, 13(9), 674-678. http:// dx.doi.org/10.1038/nrc3572. PMid:23924644.

Ferri, R., Hashim, D., Smith, D. R., Guazzetti, S., Donna, F., Ferretti, E., Curatolo, M., Moneta, C., Beone, G. M., \& Lucchini, R. G. (2015). Metal contamination of home garden soils and cultivated vegetables in the province of Brescia, Italy: Implications for human exposure. The Science of the Total Environment, 518-519, 507-517. http://dx.doi. org/10.1016/j.scitotenv.2015.02.072. PMid:25777956.

Food and Agriculture Organization - FAO. (2014). Growing greener cities in Latin America and the Caribbean: a FAO report on urban and peri-urban agriculture in the region. Rome: FAO.

Freeman, M. C., Ogden, S., Jacobson, J., Abbott, D., Addiss, D. G., Amnie, G. A., Beckwith, C., Cairncross, S., Callejas, R. Colford Jr, J. M., Emerson, P. M., Fenwick, A., Fishman, R., Gallo, K., Grimes, J., Karapetyan, G., Keene, B., Lammie, P J., MacArthur, C., Lochery, P., Petach, H., Platt, J., Prabasi, S., Rosenboom, J. W., Roy, S., Saywell, D., Lisa Schechtman, L., Tantri, A., Velleman, Y., \& Utzinger, J. (2013). Integration of water, sanitation, and hygiene for the prevention and control of neglected tropical diseases: a rationale for intersectoral collaboration. PLoS Neglected Tropical Diseases, 7(9), 1-9. http://dx.doi.org/10.1371/journal.pntd.0002439. PMid:24086781.

Freitas, E. D., Rozoff, C. M., Cotton, W. R., \& Dias, P. L. S. (2007). Interactions of an urban heat island and sea-breeze circulations during winter over the metropolitan area of São Paulo, Brazil. Boundary-Layer Meteorology, 122(1), 43-65. http://dx.doi.org/10.1007/s10546-006-9091-3

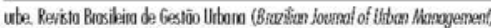


Galea, S., Uddin, M., \& Koenen, K. (2011). The urban environment and mental disorders: epigenetic links. Epigenetics, 6(4), 400-404. http://dx.doi.org/10.4161/ epi.6.4.14944. PMid:21343702.

Galli, G., Nothomb, C., \& Baetings, E. (2014). Towards systemic change in urban sanitation (IRC Working Paper). The Hague: IRC. Retrieved in 15 May 2015, from http:// www.ircwash.org/sites/default/files/201411_wp_ towardssyschangeinurbansan_web.pdf

Gasparrini, A., Armstrong, B., Kovats, S., \& Wilkinson, P. (2012). The effect of high temperatures on cause specific mortality in England and Wales. Occupational and Environmental Medicine, 69(1), 56-61. http://dx.doi. org/10.1136/oem.2010.059782. PMid:21389012.

Gasparrini, A., Guo, Y., Hashizume, M., Lavigne, E., Zanobetti, A., Schwartz, J., Tobias, A., Tong, S., Rocklōv, J., Forsberg, B., Leone, M., De Sario, M., Bell, M. L., Guo, Y. L., Wu, C., Kan, H., Yi, S. M., Coelho, M. S. Z. S., Saldiva, P. H. N., Honda, Y., Kim, H., \& Armstrong, B. (2015). Mortality risk attributable to high and low ambient temperature: a multicountry observational study. Lancet, 386(9991), 369375. http://dx.doi.org/10.1016/S0140-6736(14)62114-0. PMid:26003380.

Gatto, N. M., Martinez, L. C., Spruijt-Metz, D., \& Davis, J. N. (2015). LA sprouts randomized controlled nutrition and gardening program reduces obesity and metabolic risk in latino youth. Obesity (Silver Spring, Md.), 23(6), 1244-1251. http://dx.doi.org/10.1002/oby.21077. PMid:25960146.

Grandjean, P., \& Landrigan, P. J. (2006). Developmental neurotoxicity of industrial chemicals. Lancet, 368(9553), 2167-2178. http://dxdoi.org/10.1016/S0140-6736(06)696657. PMid:17174709.

Guo, Y., Gasparrini, A., Armstrong, B., Li, S., Tawatsupa, B., Tobias, A., Lavigne, E., de Sousa Zanotti Stagliorio Coelho, M., Leone, M., Pan, X., Tong, S., Tian, L., Kim, H., Hashizume, M., Honda, Y., Guo, Y. L., Wu, C. F., Punnasiri, K., Yi, S. M., Michelozzi, P., Saldiva, P. H., \& Williams, G. (2014). Global variation in the effects of ambient temperature on mortality a systematic evaluation. Epidemiology (Cambridge, Mass.), 25(6), 781-789. http://dx.doi.org/10.1097/ EDE.0000000000000165. PMid:25166878.

Haines, A., McM ichael, A. J.,Smith, K. R., Roberts, l., Woodcock, J., Markandya, A., Armstrong, B. G., Campbell-Lendrum, D., Dangour, A. D., Davies, M., Bruce, N., Tonne, C., Barrett, M., $\&$ Wilkinson, P. (2009). Public health benefits of strategies to reduce greenhouse-gas emissions: overview and implications for policymakers. Lancet, 374(9707), 2104 2114.http://dx.doi.org/10.1016/S0140-6736(09)61759-1 PMid:19942281.

Hara, Y., Tsuchiya, K., Matsuda, H., Yamamoto, Y., \& Sampei, Y. (2013). Quantitative assessment of the Japanese "local production for local consumption" movement: a case study of growth of vegetables in the Osaka city region. Sustainability Science, 8(4), 515-527. http://dx.doi. $\operatorname{org} / 10.1007 / \mathrm{s} 11625-012-0198-9$

Harpham, T. (2009). Urban health in developing countries: what do we know and where do we go? Health \& Place, 15(1), 107-116.

Haynes, R. C. (2010). A worn-out welcome: renewed call for a global ban on asbestos. Environmental Health Perspectives, 118(7), 298-303. http://dx.doi.org/10.1289/ ehp.118-a298 PMid:20601321.

Hsieh, C. C., Chang, K., \& Kao, Y. (1999). Estimating the ozone formation potential of volatile aromatic compounds in vehicle tunnels. Chemosphere, 39(9), 1433-1444. http://dx.doi.org/10.1016/S0045-6535(99)00045-4. PMid:10481245.

Hu, F. B., Manson, J. E., \& Willett, W. C. (2001). Types of dietary fat and risk of coronary heart disease: a critical review. Journal of the American College of Nutrition, 20(1), 5-19. http://dx.doi.org/10.1080/07315724.2001.107190 08. PMid:11293467.

Instituto Brasileiro de Geografia e Estatistica - IBGE. (2011). Pesquisa Nacional por Amostra de Domicilio 2001-2011. Rio de Janeiro; IBGE. Retrieved in 15 May 2015, from http:// seriesestatisticas.ibge.gov.br/series.aspx?vcodigo=PD27 6

Intergovernmental Panel on Climate Change - IPCC. (2013). Climate change 2013: the physical science basis. Contribution of working group I to the fifth assessment report of the intergovernmental panel on climate change. Cambridge: Cambridge University Press. Retrieved in 20 August 2015, from http://www.ipcc.ch/pdf/assessmentreport/ar5/wg1/WG1AR5_ALL_FINAL.pdf

International Agency for Research on Cancer - IARC. (2009). A review of human carcinogens Part $C$ : arsenic, metals, fibres, and dusts (IARC Working Group on the Evaluation of Carcinogenic Risks to Humans). Lyon: LARC. Retrieved in 30 May 2015, from http://monographs.iarc.fr/ENG/ Monographs/vol100C/mono100C.pdf 
Kessler R. (2013). Urban gardening: managing the risks of contaminated soil. Environ Health Perspect, 121(1112), 326-333.

Khan, S. M., \& Simpson, R. W. (2001). Effect of a heat island on the meteorology of complex urban airshed. Boundary-Layer Meteorology, 100(3), 487-506. http:// dx.doi.org/10.1023/A:1019284332306.

Krieger, N. (2014). Urbanismo ecológico e equidade no domínio da saúde: uma perspectiva ecossocial. In Mostafavi, M. \& Doherty, G. Urbanismo ecológico (p. 518-519). São Paulo: Editora G. Gilli.

Laborde, A., Tomasina, F., Bianchi, F., Bruné, M. N., Buka, L., Comba, P., Corra, L., Cori, L., Duffert, C. M., Harari, R., lavarone, L., McDiarmid, M. A., Gray, K. A., Sly, P. D., Soares, A., Suk, W. A., \& Landrigan, P. J. (2015). Children's health in Latin America: the influence of environmental exposures. Environmental Health Perspectives, 123(3), 201-210. PMid:25499717.

Laschewski, G., \& Jendritzky, G. (2002). Effects of the thermal environment on human health: an investigation of 30 years of daily mortality data from SW Germany. Climate Research, 21,91-103.http://dx.doi.org/10.3354/cr021091.

Laumbach, R., \& Kipen, H. (2014). Mechanistic data support protecting non-smokers from the lethal effects of secondhand smoke. International journal of Public Health, 59(4), 575-576. http://dx.doi.org/10.1007/s00038-014-0550-1. PMid:24781823,

Laverty, A. A., Palladino, R., Lee, J. T., \& Millett, C. (2015). Associations between active travel and weight, blood pressure and diabetes in six middle income countries: a cross-sectional study in older adults. The International Journal of Behavioral Nutrition and Physical Activity, 12(1), 65.http://dx.doi.org/10.1186/s12966-015-0223-3. PMid:25986001.

Lim, S. S., Vos, T., Lim, S. S., Vos, T., Flaxman, A. D., Danaei, G., Shibuya, K., Adair-Rohani, H., Amann, M., Anderson, H. R., Andrews, K. G., Aryee, M., Atkinson, C., Bacchus, L. J., Bahalim, A. N., Balakrishnan, K., Balmes, J., Barker-Collo, S., Baxter, A., Bell, M. L., Blore, J. D., Blyth, F., Bonner, C. Borges, G., Bourne, R., Boussinesq, M., Brauer, M., Brooks, P., Bruce, N. G., Brunekreef, B., Bryan-Hancock, C., Bucello, C., Buchbinder, R., Bull, F., Burnett, R. T., Byers, T. E., Calabria, B., Carapetis, J., Carnahan, E., Chafe, Z., Charlson, F., Chen, H., Chen, J. S., Cheng, A. T., Child, J. C., Cohen, A., Colson, K. E., Cowie, B. C., Darby, S., Darling, S., Davis, A., Degenhardt, L., Dentener, F., Des Jarlais, D. C., Devries, K., Dherani, M.,
Ding, E. L., Dorsey, E. R., Driscoll, T., Edmond, K., Ali, S. E., Engell, R. E., Erwin, P. J., Fahimi, S., Falder, G., Farzadfar, F., Ferrari, A., Finucane, M. M., Flaxman, S., \& Fowkes, F. G., Freedman, G., Freeman, M. K., Gakidou, E., Ghosh, S. Giovannucci, E., Gmel, G., Graham, K., Grainger, R., Grant, B., Gunnell, D., Gutierrez, H. R., Hall, W., Hoek, H. W., Hogan, A., Hosgood, H. D., Hoy, D., Hu, H., Hubbell, B. J., Hutchings, S. J., Ibeanusi, S. E., Jacklyn, G. L., Jasrasaria, R., Jonas, J. B., Kan, H., Kanis, J. A., Kassebaum, N., Kawakami, N., Khang, Y. H., Khatibzadeh, S., Khoo, J. P., Kok, C., Laden, F., Lalloo, R., Lan, Q., Lathlean, T., Leasher, J. L., Leigh, J., Li, Y., Lin, J. K., Lipshultz, S. E., London, S., Lozano, R., Lu, Y., Mak, J., Malekzadeh, R., Mallinger, L., Marcenes, W., March, L., Marks, R., Martin, R., McGale, P., McGrath, J., Mehta, S., Mensah, G. A., Merriman, T. R., Micha, R., Michaud, C., Mishra, V., Hanafiah, K. M., Mokdad, A. A., Morawska, L., Mozaffarian, D., Murphy, T., Naghavi, M., Neal, B., Nelson, P. K., Nolla, J. M., Norman, R., Olives, C.., Omer, S. B., Orchard, J., Osborne, R., Ostro, B., Page, A., Pandey, K. D., Parry, C. D., Passmore, E., Patra, J., Pearce, N., Pelizzari, P. M., Petzold, M., Phillips, M. R., Pope, D., Pope, C. A., Powles, J., Rao, M., Razavi, H., Rehfuess, E. A., Rehm, J. T., Ritz, B., Rivara, F. P., Roberts, T., Robinson, C., Rodriguez-Portales, J.A., Romieu, l., Room, R., Rosenfeld, L. C., Roy, A., Rushton, L., Salomon, J.A., Sampson, U., Sanchez-Riera, L., Sanman, E., Sapkota, A., Seedat, S., Shi, P., Shield, K., Shivakoti, R., Singh, G. M., Sleet, D. A., Smith, E., Smith, K. R., Stapelberg, N. J., Steenland, K., Stöckl, H. Stovner, L. J., Straif, K., Straney, L., Thurston, G. D., Tran, J. H., van Dingenen, R., van Donkelaar, A., Veerman, J. L., Vijayakumar, L., Weintraub, R., Weissman, M. M., White, R. A., Whiteford, H., Wiersma, S. T., Wilkinson, J. D., Williams, H. C., Williams, W., Wilson, N., Woolf, A. D., Yip, P., Zielinski, J. M., Lopez, A. D., Murray, C. J., Ezzati, M., AlMazroa, M. A., \& Memish, Z. A. (2012). A comparative risk assessment of burden of disease and injury attributable to 67 risk factors and risk factor clusters in 21 regions, 1990-2010: a systematic analysis for the Global Burden of Disease Study 2010. Lancet, 380(9859), 2224-2260.

Ludwig, J., Duncan, G. J., Gennetian, L. A., Katz, L. F., Kessler, R. C., Kling, J. R., \& Sanbonmatsu, L. (2013). Long-term neighborhood effects on low-income families: evidence from Moving to Opportunity. American Economic Review, American Economic Association, 103(3), 226-231.

Marengo, J. A., Jones, R., Alves, L. M., \& Valverde, M. (2009). Future change of temperature and precipitation extremes in South America as derived from the PRECIS regional climate modeling system. International Journal of Climatology, 29(15), 2241-2255. http://dx.doi.org/10.1002/joc.1863.

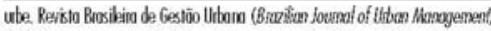


McMichael, A. J. (1996). Transport and health: assessing the risks. In T. Fletcher, \& A. J. McMichael (Eds.), Health at the crossroads: transport policy and urban health (p. 9-26). Chichester: John Wiley \& Sons.

Merzel, C. (2000). Gender differences in health care access indicators in an urban, low-income community. American Journal of Public Health, 90(6), 909-916. http://dx.doi. org/10.2105/AJPH.90.6.909. PMid:10846508.

Middle, L., Dzidic, P., Buckley, A., Bennett, D., Tye, M., \& Jones, R. (2014). Integrating community gardens into public parks: an innovative approach for providing ecosystem services in urban areas. Urban Forestry \& Urban Greening, 13(4), 638-645. http://dx.doi.org/10.1016/j.ufug.2014.09.001.

Milburn, L. S., \& Vail, B. A. (2010). Sowing the seeds of success: cultivating a future for community gardens. Landscape Journal, 29(1), 1-10. http://dx.doi.org/10.3368/ lj.29.1.71.

Mostafavi, M., \& Doherty, G. (2014). Urbanismo ecológico. São Paulo: Gustavo Gili.

Mueller, N., Rojas-Rueda, D., Cole-Hunter, T., Nazelle, A., Dons, E., Gerike, R., Götschi, T., Panis, L. L., Kahlmeier, S., \& Nieuwenhuijsen, M. (2015). Health impact assessment of active transportation: A systematic review. Preventive Medicine, 76, 103-114, http://dx.doi.org/10.1016/j. ypmed.2015.04.010. PMid:25900805.

Nawrot, T.S., Perez, L., Künzli, N., Munters, E., \& Nemery, B. (2011). Public health importance of triggers of myocardial infarction: a comparative risk assessment. Lancet, 377(9767). 732-740.

Newman, P., \& Kenworthy, G. (1999). Cities and sustainability: reducing auto dependency. Washington, D.C.: Island Press.

O'Reilly, K. M. A., McLaughlin, A. M., Beckett, W. S., \& Sime P. . (2007). Asbestos-related lung disease. American Family Physician, 75(5), 683-688. PMid:17375514.

Ollila, E. (2011). Health in all policies: from rhetoric to action. Scandinavian Journal of Public Health, 39(6, Suppl.), 11-18. http://dx.doi.org/10.1177/1403494810379895. PMid:20813799.

Pan American Health Organization - PAHO. (2013). WHOAlMS: report on mental health systems in Latin America and the Caribbean. Washington, D.C: PAHO.

Peen, J., Schoevers, R. A., Beekman, A. T., \& Dekker, J. (2010). The current status of urban-rural differences in psychiatric disorders. Acta Psychiatrica, 121(2), 84-93.
Pucher, J., \& Buehler, R. (2007). At the frontiers of cycling: policy innovations in the Netherlands, Denmark, and Germany. World Transport Policy and Practice, 13, 9-56.

Pucher, J., \& Buehler, R. (2008). Making cycling irresistible: lessons from the Netherlands, Denmark and Germany. Transport Reviews, 28(4), 495-528. http://dx.doi. org/10.1080/01441640701806612.

Rissel,C. E. (2009). Active travel: a climate change mitigation strategy with co-benefits for health. New South Wales Public Health Bulletin, 20(1-2), 10-13. http://dx.doi.org/10.1071/ NB08043. PMid:19261210.

Rydin, Y., Bleahu, A., Davies, M., Dávila, J. D., Friel, S., De Grandis, G., Groce, N., Hallal, P. C., Hamilton, L., HowdenChapman, P., Lai, K., Lim, C. J., Martins, J., Osrin, D., Ridley, I., Scott, L., Taylor, M., Wilkinson, P., \& Wilson, J. (2012). Shaping cities for health: complexity and the planning of urban environments in the 21st century. Lancet, 379(9831), 2079-2108.http://dx.doi.org/10.1016/S01406736(12)60435-8. PMid:22651973.

Saldiva, P. (2010). 0 homem e o meio ambiente urbano. In Saldiva, P. \& Vormittag, E. M. P. A. A. Meio ambiente $e$ saúde: o desafio das metrópoles (p. 18-20). São Paulo: ExLibris Comunicação Integrada.

Saldiva, P. H. N., King, M., Delmonte, V. L. C., Macchione, M., Parada, M. A. C., Daliberto, M. L., Sakae, R. S., Criado, P. M. P., Parada, P. L. P., Zin, W. A., \& Böhm, G. M. (1992). Respiratory alterations due to urban air pollution: an experimental study in rats. Environmental Research, 57(1), 19-33. http://dx.doi.org/10.1016/S0013-9351(05)800167. PMid: 1371246 .

Saunders, L. E., Green, J. M., Petticrew, M. P., Steinbach, R., \& Roberts, H. (2013). What are the health benefits of active travel? A systematic review of trials and cohort studies. PLoS One, 8(8), 1-13.

Sebrié, E. M., Schoj, V., \& Glantz, S. A. (2008). Smoke free environments in Latin America: on the road to real change? Prevention and Control, 3(1), 21-35. http://dx.doi. org/10.1016/j.precon.2007.09.001. PMid:19578527.

Shive, L., \& Shive, M. (2014). Indoor temperature below $18{ }^{\circ} \mathrm{C}$ accounts for $9 \%$ population attributable risk for high blood pressure in Scotland. International Journal of Cardiology, 171(1), e1-e2. http://dx.doi.org/10.1016/j. ijcard.2013.11.040. PMid:24315341.

Silva Dias, M. M. F., Dias, J., Carvalho, L. M. V., Freitas, E. D., \& Silva Dias, P. L. (2013). Changes in extreme daily rainfall

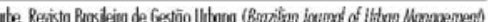


for São Paulo, Brazil. Climatic Change, 116(3-4), 705-722. http://dx.doi.org/10.1007/s10584-012-0504-7.

Smith, K. R., Frumkin, H., Balakrishnan, K., Butler, C. D., Chafe, Z. A., Fairlie, L., Kinney, P., Kjellstrom, T., Mauzerall, D. L., McKone, T. E., McMichael, A. J., \& Schneider, M. (2013). Energy and human health. Annual Review of Public Health, 34(1), 159-188, http://dx.doi.org/10.1146/annurevpublhealth-031912-114404. PMid:23330697.

Smith, K. R., McCracken, J. P., Weber, M. W., Hubbard, A., Jenny, A., Thompson, L. M., Balmes, J., Diaz, A., Arana, B., \& Bruce, N. (2011). Effect of reduction in household air pollution on childhood pneumonia in Guatemala (RESPIRE): a randomised controlled trial. Lancet, 378(9804), $1717-$ 1726. http://dx.doi.org/10.1016/S0140-6736(11)60921-5. PMid:22078686.

Snyder, R. E., Jaimes, G., Riley, L. W., Faerstein, E., \& Corburn, J. (2014). A comparison of social and spatial determinants of health between formal and informal settlements in a large metropolitan setting in Brazil.Journal of Urban Health, 91(3), 432-445. http://dx.doi.org/10.1007/s11524-0139848-1. PMid:24297475.

Sobral, R. H. (2005). Heat Island in São Paulo, Brazil. Critical Public Health, 15(2), 147-156. http://dx.doi. org/10.1080/09581590500151756.

Solecki, W. D., Rosenzweig, C., Parshall, L., Popec, G., Clarkc, M., Coxa, J., \& Wiencked, M. (2005). Mitigation of the heat island effect in urban New Jersey. Global Environmental Change Part B: Environmental Hazards, 6(1), 39-49.

Souza, E. L. L., \& Macedo, L. (2010). Etanole bioeletricidade: a cana-de-açucar no futuro da matriz energética. São Paulo: União da Indústria de Cana-de-Açúcar.

Swinton, S. M., Lupi, F., Robertson, G. P., \& Hamilton, S. K. (2007). Ecosystem services and agriculture: cultivating agricultural ecosystems for diverse benefits. Ecological Economics, 64(2), 245-252. http://dx.doi.org/10.1016/j. ecolecon.2007.09.020

Tan, J., Zheng, Y., Tang, X., Guo, C., Li, L., Song, G., Zhen, X., Yuan, D., Kalkstein, A. J., Li, F., \& Chen, H. (2010). The urban heat island and its impact on heat waves and human health in Shanghai. International Journal of Biometeorology, 54(1), 75-84. http://dx.doi.org/10.1007/s00484-009-0256-x. PMid:19727842.

Thomson, H., Thomas, S., Sellstrom, E., \& Petticrew, M. (2013). Housing improvements for health and associated socioeconomic outcomes. Cochrane Database of Systematic Reviews, 2, CD008657.

Tohill, B. C., Seymour, J., Serdula, M., Kettel-Khan, L., \& Rolls, B. J. (2004). What epidemiologic studies tell us about the relationship between fruit and vegetable consumption and body weight. Nutrition Reviews, 62(10), 365-374. http://dx.doi.org/10.1111/j.1753-4887.2004.tb00007.x. PMid:15508906.

Torreggiani, D., Dall'Ara, E., \& Tassinari, P. (2012). The urban nature of agriculture: bidirectional trends between city and countryside. Cities (London, England), 29(6), 412-416. http://dx.doi.org/10.1016/j.cities.2011.12.006.

United Nations - UN. (2010). The human right to water and sanitation. Resolution adopted by the General Assembly. Zaragoza: United Nations. Retrieved in 2 May 2015, from http://www.un.org/es/comun/docs/? symbol=A/ RES/64/292\&lang $=E$

United States Environment Protection Agency - EPA (2006). Excessive heat events guidebook. Washington, D.C: EPA. Retrieved in 15 April 2015, from www.epa.gov/hiri/ about/pdf/EHEguide_final.pdf

United States Environmental Protection Agency - EPA (2014). Green infrastructure. Washington, D.C: EPA. Retrieved in 15 August 2015, from waterepa.gov/infrastructure/ greeninfrastructure

Urban, A., Davídkovová, H., \& Kyselý, J. (2014). Heatand cold-stress effects on cardiovascular mortality and morbidity among urban and rural populations in the Czech Republic. International Journal of Biometeorology. 58(6), 1057-1068. http://dx.doi.org/10.1007/s00484013-0693-4. PMid:23793998.

Vahlsing, C., \& Smith, K. R. (2012). Global review of national ambient air quality standards for PM10 and SO2 (24 h). Air Quality, Atmosphere \& Health, 5(4), 393-399. http:// dx.doi.org/10.1007/s11869-010-0131-2. PMid:23205158.

Wang, X., \& Zhang, Y. (2009). A new method for determining the initial mobile formaldehyde concentrations, partition coefficients, and diffusion coefficients of dry building materials. Journal of the Air \& Waste Management Association, 59(7), 819-825. http://dx.doi.org/10.3155/1047-3289.59.7.819 PMid:19645266.

Warming, M., Hansen, M. G., Holm, P. E., Magid, J., Hansen, T. H., \& Trapp, S. (2015). Does intake of trace elements through urban gardening in Copenhagen pose a risk to 
human health? Environmental Pollution, 202, 17-23. http:// dx.doi.org/10.1016/j.envpol.2015.03.011 PMid:25796073.

Watts, N., Adger, W. N., Agnolucci, P., Blackstock, J., Byass, P., Cai, W., Chaytor, S., Colbourn, T., Collins, M., Cooper, A., Cox, P. M., Depledge, J., Drummond, P., Ekins, P., Galaz, V., Grace, D., Graham, H., Grubb, M., Haines, A., Hamilton, L., Hunter, A., Jiang, X., Li, M., Kelman, L., Liang, L., Lott, M., Lowe, R., Luo, Y., Mace, G., Maslin, M., Nilsson, M., Oreszczyn, T., Pye, S., Quinn, T., Svensdotter, M., Venevsky, S., Warner, K., Xu, B., Yang, J., Yin, Y., Yu, C., Zhang, Q., Gong, P., Montgomery, H., Costello, A. (2015). Health and climate change: policy responses to protect public health. Lancet, 386(10006), 1861-1914

Weich, S., Lewis, G., \& Jenkins, S. (2001). Income inequality and the prevalence of common mental disorders in Britain. The British Journal of Psychiatry, 178(3), 222-227. http:// dx.doi.org/10.1192/bjp.178.3.222 PMid:11230032.

Wilkinson, P., Smith, K. R., Davies, M., Adair, H., Armstrong, B. G., Barrett, M., Bruce, N., Haines, A., Hamilton, L., Oreszczyn, T., Ridley, l., Tonne, C., \& Chalabi, Z. (2009). Public health benefits of strategies to reduce greenhouse-gas emissions: household energy. Lancet, 374(9705), 1917-1929. http:// dx.doi.org/10.1016/S0140-6736(09)61713-XPMid:19942273.

Wolch, ]. R., Byrne, ]. \& Newell, J. P. (2014), Urban green space, public health, and environmental justice: the challeng of making cities 'just green enough'. Landscape and Urban Planning, 125, 234-244, http://dx.doi.org/10.1016/ landurbplan.2014.01.017

World Health Organization - WHO, (2004), Urban bioclimatology in health and global environmental change.
Retrieved in 30 November 2009, from http://www.euro. who.int/globalchange

World Health Organization - WHO. (2011). Health in the green economy: health co-benefits of climate change mitigation: transport sector. Geneva: WHO. Retrieved in 7 November 2012, from http://www.who.int/hia/examples/ trspt_comms/hge_transport_lowresdurban_30_11_2011.pdf World Health Organization - WHO. (2014a). Social determinants of mental health. Geneva: WHO.

World Health Organization - WHO. (2014b). 7 million premature deaths annually linked to air pollution. Geneva: WHO. Retrieved in 5 November 2014, from http://www.who. int/mediacentre/news/releases/2014/air-pollution/en/

World Health Organization/United Nations Children's Fund - WHO/UNICEF. (2014). Progress on drinking water and sanitation: 2014 update. Geneva: WHO/UNICEF. Retrieved in 2 May 2015, from http://www.who.int/ water_sanitation_health/publications/2014/jmp-report/en/

World Health Organization/United Nations Children's Fund - WHO/UNICEF. (2015). Improved and unimproved water sources and sanitation facilities. Geneva: WHO. Retrieved in 2 May 2015, from http://www.wssinfo.org/ definitions-methods/watsan-categories/

Zezza, A., \& Tasciotti, L. (2010). Urban agriculture, poverty, and food security: empirical evidence from a sample of developing countries. Food Policy, 35(4), 265-273. http:// dx.doi.org/10.1016/j.foodpol.2010.04.007

Received: June 15, 2015

Approved: 0ct. 05, 2015 


\section{DISCUSSÃO}

Trabalhando no terceiro setor eu almejava contribuir para a promoção de uma cidade mais saudável. Ao longo do tempo percebi que as relações entre urbanidade e qualidade de vida eram demasiadamente complexas e vi na ciência um instrumento que poderia me auxiliar a compreender melhor essas relações. Ingressei na pós-graduação com a expectativa de dominar algumas técnicas científicas, de ser capaz de produzir pesquisa independente, de integrar conhecimentos científicos e resultados complexos e criar artigos de qualidade para reportar o conhecimento produzido. Mais que isso, eu queria entender como a ciência pensa e ao mesmo tempo desenvolver habilidades de tradução dos achados científicos em narrativas compreensíveis para um público mais geral. Embora esse processo de aprendizado terá que ser desenvolvido continuamente ao longo da vida, sinto que o ingresso na pós-graduação foi positivo para que eu começasse a desenvolver essas habilidades.

Nos resultados desta tese apresentei minha experiência com oito manuscritos, em formatos diversos e para públicos variados, sete deles de alguma forma já publicados $^{(10,11,25,53,56-58)}$ e o oitavo já submetido. A preparação dos manuscritos seguiu um processo dinâmico, onde o aprendizado com cada artigo resultou em novas habilidades e perguntas de pesquisa. Por exemplo, o primeiro estudo (tipologia 1, poluição do ar e câncer) ${ }^{(53)}$, influenciou os demais, tanto no que diz respeito a gerar novas perguntas de pesquisa, quanto no que diz respeito a forma de construção da narrativa. A pergunta do manuscrito da tipologia $2^{(57)}$, "qual a cobertura de monitoramento de poluição do ar em países em desenvolvimento?” surgiu a partir de constatações feitas durante o primeiro estudo. São elas: a) estudos sobre poluição do ar e saúde são relativamente escassos em países em desenvolvimento comparado com 
países desenvolvidos; b) a contribuição de evidências produzidas em países em desenvolvimento é escassa em análises globais sobre poluição do ar e saúde como as conduzidas pelo IARC* . Cenário semelhante (ausência de estudos associando material particulado fino e eventos diários de saúde) contribuiu para a formulação da pergunta de pesquisa da revisão sistemática (tipologia 3). Mapear dados secundários como estratégia de construção de narrativas também foi usado no capítulo de livro sobre poluição do ar e reprodução humana ${ }^{(58)}$ (tipologia 4) e na construção do índice de defasagem tecnológica $^{(56)}$ (manuscrito sobre co-benefícios para a saúde de políticas de baixo carbono, tipologia 1). Transcender o tema poluição do ar e trabalhar com outros temas relacionados a urbanidade e qualidade de vida, indica que avancei na análise de temas complexos, como me propus inicialmente. Os manuscritos incluídos na tipologia 4, demonstram que foi possível produzir artigos que integrem diferentes áreas de conhecimento sob a forma de narrativas compreensíveis para um público mais amplo. Cada um dos quatro manuscritos desta tipologia foi publicado num veículo voltado para públicos diversos, como urbanistas no caso da Revista Urbe ${ }^{(11)}$ e gestores públicos no caso da revista Estudos Avançados ${ }^{(10)}$. Acredito que este resultado permite afirmar que é possível produzir artigos científicos de bom nível que, ao mesmo tempo integrem diferentes áreas de conhecimento e orientem formadores de opinião, gestores públicos e órgãos legislativos desejosos de estimular políticas voltadas para a promoção da saúde e qualidade de vida, como perguntado no objetivo desta tese.

Ao longo da pós-graduação participei ainda de outros estudos não mencionados na sessão de Resultados, um deles finalizado, mas ainda não publicado. Trata-se de uma contribuição sobre as relações entre saúde humana e crise hídrica para um dossiê sobre a

\footnotetext{
* IARC corresponde à sigla em inglês que designa a Agência Internacional de Pesquisa sobre Câncer, vinculada à Organização Mundial da Saúde.
} 
crise hídrica de São Paulo. Intitulado o livro Branco da Água, o dossiê reuniu cientistas de diversas áreas sob a coordenação da Academia de Ciências do Estado de São Paulo e do Instituto de Estudos Avançados (IEA) da Universidade de São Paulo e visa atingir especialistas e tomadores de decisão. O dossiê será publicado em breve e pode ser acessado na seção de Anexos desta tese (Anexo C). Ter sido solicitada para escrever sobre água e saúde, indica que as habilidades que desenvolvi ao longo da pós-graduação podem ser utilizadas para abordar outros temas do guarda-chuva saúde e urbanidade.

Quando transferi minha pós-graduação do mestrado para o doutorado direto, acordei com meu orientador que eu aprenderia técnicas de revisão sistemática e metanálise, o que fiz através de uma especialização. A especialização resultou num manuscrito já submetido (vide seção de Resultados) e num segundo baseado na mesma pergunta de pesquisa, mas para o poluente $\mathrm{MP}_{10}{ }^{*}$, ao invés do $\mathrm{MP}_{2.5}{ }^{\dagger}$ e está em processo de preparação. Uma nova pergunta de pesquisa surgiu a partir desta revisão sistemática e será investigada através de um overview $w^{\ddagger}$ (vide registro do protocolo da pesquisa na seção de Anexos, Anexo D). O aprendizado sobre revisão sistemática aprimorou minhas habilidades em procurar, selecionar, avaliar a qualidade e sintetizar evidências científicas e as tenho também utilizado na condução de revisões não sistemáticas. De fato, tenho uma certa fluência no tema, a ponto de ministrar aulas sobre o assunto em outras Faculdades e ter sido convidada para participar de uma revisão sobre exposição gestacional à poluição do ar e desenvolvimento pulmonar, em curso neste momento.

Assim como aconteceu nos objetivos, métodos e resultados, as discussões correspondentes a cada um dos manuscritos que compõe esta tese está contida no corpo

\footnotetext{
${ }^{*}$ Tipo de poluente atmosférico definido por seu tamanho, no caso do $\mathrm{MP}_{10}$, material particulado com diâmetro aerodinâmico menor que 10 micrômetros.

$\dagger$ Tipo de poluente atmosférico definido por seu tamanho, no caso do $\mathrm{MP}_{2.5}$, material particulado com diâmetro aerodinâmico menor que 2.5 micrômetros.

¥O termo em inglês "overview” é usado pelos teóricos em revisão sistemáticas e ainda não possui tradução para o português. Refere-se a revisões de revisões sistemáticas.
} 
dos mesmos (vide seção de Resultados). Deste modo vou me dedicar a discutir aspectos mais gerais e conceituais que não puderam ser transformados em artigos, mas que de alguma forma indicam a minha transformação ao longo da pós-graduação.

Em primeiro lugar, convenci-me ainda mais que o tema urbanidade e qualidade de vida é complexo. As cidades não são fáceis de gerir, cada intervenção acarreta uma série de efeitos na cidade, nem sempre previsíveis ou desejáveis ${ }^{(31)}$.

Políticas baseadas em evidência são um instrumento valioso para gerir as cidades $^{(47,48,59)}$. Prevenir exposições ambientais que a ciência mostrou serem tóxicas $^{(55,60-63)}$, reduzir inequidades em saúde ${ }^{(61-65)}$ e melhorar a eficiência dos gastos públicos são apenas alguns dos benefícios potenciais de política públicas baseadas em evidência. Ademais, politicas baseadas em evidência aprimoram a qualidade e a legitimidade das democracias ${ }^{(47)}$.

Informar políticas públicas tem sido tema cada vez mais central da agenda científica $^{(64)}$. Ao longo das últimas décadas, a comunidade científica tem desenvolvido uma série de estratégias metodológicas para diminuir a distância entre política e evidência, notadamente técnicas de revisão sistemática $^{(60,66,67)}$ e metodologias de avaliação da qualidade da evidência, desenvolvidas e aplicadas não só por algumas revisões sistemáticas ${ }^{(60,68)}$, mas também por grupos maiores de pesquisadores e especialistas, como Sociedades Médicas e organizações internacionais e multiprofissionais como o IARC* e o IPCC ${ }^{\dagger}$. No campo da saúde, os pesquisadores tem sido cada vez mais desafiados a mostrar que estão impactando políticas públicas e ajudando a reduzir a distância entre evidência e política, tanto por alguns pré-requisitos

\footnotetext{
* IARC corresponde à sigla em inglês que designa a Agência Internacional de Pesquisa sobre Câncer, vinculada à Organização Mundial da Saúde.

† IPCC corresponde à sigla em inglês que designa o Painel Intergovernamental sobre Mudanças Climáticas composto por centenas de cientistas qualificados e vinculado a Organização Mundial de Meteorologia e ao Programa das Nações Unidas para o Meio Ambiente.
} 
de financiamento, quanto por alguns pré-requisitos de publicação. No entanto, a transformação do conhecimento científico em melhores decisões políticas não ocorre de forma natural ${ }^{(48)}$. Não basta produzir ciência de qualidade, é também preciso apresentála de uma forma compreensível para um público mais abrangente, particularmente gestores públicos, órgãos legislativos e formadores de opinião, o que dentro da teoria de produção de políticas públicas é chamado de transferência do conhecimento $^{(48)}$. Estratégias de melhor tradução do conhecimento são de fato fundamentais ${ }^{(69)}$. A função do pesquisador é produzir ciência no mais alto nível de qualidade possível, mas não necessariamente traduzi-la. São exceções os cientistas que também produzem boas narrativas sobre suas pesquisas. Para traduzir ciência é preciso entender sobre ciência e sobre o público receptor, o que não é uma tarefa fácil. Para traduzir a ciência é preciso se equilibrar entre uma narrativa responsável, que defina acertos e limitações das conclusões, sem se prender na incerteza, característica inerente do linguajar científico. Embora não tenha sido o objetivo deste estudo, percebi que o que a sociedade quer saber é se a poluição dá ou não câncer, se determinada fonte de água é segura ou não para beber e outras definições que os métodos científicos que utilizamos nem sempre nos permitem afirmar. Como já mencionado, a qualificação das evidências científicas é e deve continuar a ser feita por organizações que desenvolveram metodologias e critérios específicos para isso e ainda contam com a colaboração de diversos cientistas e especialistas com diferentes formações para avaliar o conjunto de evidências, como ocorre no IARC* e IPCC ${ }^{\dagger}$. No entanto, a construção cuidadosa de uma boa narrativa também pode ajudar a interlocução entre ciência e os interessados nos seus achados,

\footnotetext{
* IARC corresponde à sigla em inglês que designa a Agência Internacional de Pesquisa sobre Câncer, vinculada à Organização Mundial da Saúde.

+ IPCC corresponde à sigla em inglês que designa o Painel Intergovernamental sobre Mudanças Climáticas composto por centenas de cientistas qualificados e vinculado a Organização Mundial de Meteorologia e ao Programa das Nações Unidas para o Meio Ambiente.
} 
incluindo pesquisadores de outras áreas. Uma das contribuições notáveis da Faculdade de Saúde Pública de Harvard é o boletim informativo ${ }^{*}$, onde eles transformam uma série de estudos moleculares e com metodologias complexas numa narrativa compreensível para a população em geral. Os pesquisadores da Harvard em si permanecem comprometidos com a produção do melhor conhecimento possível e a Universidade, como política interna, coloca este conhecimento disponível para a população.

Segundo Choi ${ }^{(48)}$, a produção de políticas baseadas em evidência envolve gerar, transferir e incorporar conhecimento e o sucesso de uma determinada política depende da contemplação de todas essas etapas. Neste estudo, pude experimentar principalmente estratégias que $\mathrm{Choi}^{(48)}$ classifica como pertencentes à etapa de transferência do conhecimento. As estratégias sugeridas pelo autor para aprimorar a transferência do conhecimento são: a) produção de conteúdo relevante, b) tradução apropriada, c) timing $^{\dagger}$ e d) novos métodos de organizar e publicar a informação prioritária. Os manuscritos que compõe essa tese de certa forma abrangeram todas as estratégias sugeridas, exceto a última.

Convenci-me ainda mais que não basta produzir ciência de qualidade e apresentá-la de uma forma compreensível para um público mais abrangente, é preciso integrar os conhecimentos científicos de diversas áreas numa mesma narrativa. Ou seja, frente a complexidade das relações entre urbanidade e qualidade de vida, não basta a narrativa de um setor, é preciso integrar o conhecimento em narrativas, mas também integrar as diversas narrativas. É este o ponto ao qual me referi na introdução desta tese, quando disse que a saúde saiu da caixa da saúde. É justamente a integração de diversas

\footnotetext{
* O boletim é geralmente enviado por e-mail, mas também pode ser acessado pelo website: http://www.health.harvard.edu/.

${ }^{\dagger}$ Timing em português pode ser entendido como um momento extremamente oportuno e favorável para a divulgação de uma determinada informação, considerando contextos sociais mais amplos, como por exemplo a publicação do artigo sobre poluição e câncer ${ }^{(53)}$ no momento em que se discutia se o câncer era carcinogênico para humanos.
} 
narrativas que tem o potencial de fazer frente ao desafio de gerir cidades que promovam a qualidade de vida de seus habitantes. Ainda há muitas perguntas sobre como essa integração poderia ocorrer mais efetivamente. Há pesquisadores que desencorajam a integração de conhecimentos científicos produzidos a partir de teorias conceituais diferentes $^{(70)}$. Outros, apontam caminhos como o uso de abordagens sistêmicas ${ }^{(71)}$, mas as sugestões ainda se restringem quase que exclusivamente ao campo teórico.

Recentemente a Universidade de São Paulo (USP) lançou um Programa que pretende mostrar possíveis caminhos para integrar narrativas de diversos setores e, em última análise, devolver a sociedade o conhecimento produzido dentro da Universidade. Hospedado no Instituto de Estudos Avançados da Universidade de São Paulo*, o Programa USP Cidades Globais esta desenvolvendo uma metodologia para utilizar os recursos intelectuais da USP para integrar o conhecimento de forma a prover meios para que São Paulo atinja o mais alto nível como cidade global ${ }^{\dagger}$. Coordenado pelo prof. Marcos Buckeridge, a metodologia inicial foi inspirada na teoria de redes complexas e visa identificar propriedades emergentes, entendidas pelo Programa como as relações entre as diversas áreas do conhecimento produzido na USP sobre cidades. Algumas das relações entre disciplinas diversas do conhecimento já são conhecidas e podem ser potencializadas. Além disso, relações antes ocultas podem emergir a partir da integração de diferentes áreas do conhecimento. A partir destas relações, o Programa pretende construir uma narrativa conjunta, guiada pelo objetivo comum de melhorar a qualidade de vida e o bem-estar dos habitantes de São Paulo. A visão do Programa é aumentar a qualidade de vida e bem-estar dos paulistanos e quem sabe implementar um instituto de cidades globais na USP no futuro. Lançado para o público geral em julho de 2016, faço

\footnotetext{
* O Instituto de Estudos Avençados da Universidade de São Paulo é atualmente presidido pelo meu orientador, Prof. Paulo Saldiva, um dos idealizadores do Programa USP Cidades Globais.

${ }^{\dagger}$ Cidade Globais são aquelas que mais influenciam o mundo conforme cinco domínios: negócios, capital humano, troca de informações, experiência cultural e engajamento político ${ }^{(78)}$.
} 
parte da coordenadoria executiva do Programa, onde pretendo desenvolver melhor habilidades de integração de narrativas envolvendo o complexo sistema urbanidade e qualidade de vida. A visão do Programa está de acordo com um entendimento da importância de valores na gestão das cidades, também advogado por um grupo de cientistas através de um movimento chamado "Planetary Health"*(34).

Na prática, o sucesso de uma política baseada em evidências pode envolver outros aspectos não abordados por Choi $^{(48)}$. Ademais, as políticas públicas nem sempre são guiadas por valores como uma melhor qualidade de vida para o maior número de pessoas possível. Por exemplo, no caso do controle da poluição do ar, políticas baseadas em evidência têm sido muitas vezes adiadas nos países em desenvolvimento ${ }^{(72)}$, em virtude de um aparente dilema entre crescimento econômico e proteção da saúde humana e ambiental, acarretando na perda de benefícios potenciais para a saúde da população e para o meio ambiente, já extensivamente demonstrados ${ }^{(73)}$. A concepção de que é preciso crescer primeiro para só depois controlar a poluição ambiental, surgiu na década de 90, com base em observações temporais do desempenho econômico e ambiental de países que, de forma geral, obedeciam a uma curva de $U$ invertido, conhecida como curva de Kuznets ${ }^{(49,50,74,75)}$. A corrente que defende que economia e desempenho ambiental não são variáveis necessariamente acopladas, que o desempenho ambiental depende de outros fatores ${ }^{(50,75)}$ e que a poluição não melhora com a melhora da economia, mas sim a partir da adoção rigorosa de políticas públicas de controle ${ }^{(49)}$ são menos ouvidas no Brasil e em outros países em desenvolvimento. Possivelmente isso ocorre mais em virtude da disputa de interesses econômicos na sociedade, do que pela qualidade da evidência científica apresentada pelo segundo grupo, indicando uma

\footnotetext{
* Além da série de artigos publicados no The Lancet, o grupo de cientistas publicou um manifesto no mesmo jornal que atingiu mais de sete mil assinaturas: http://www.thelancet.com/manifesto/planetaryhealth.
} 
predominância de valores econômicos, em detrimento de valores diretamente relacionados com a qualidade de vida da maioria da população.

Falhar, adiar ou demorar para tomar ações baseadas em evidência não é uma escolha política neutra ou livre de consequências ${ }^{(60)}$ e pode privar a população de usufruir benefícios para saúde já apontados pela ciência ${ }^{(60,73)}$. No mundo todo é preciso diminuir o tempo discorrido entre a descoberta científica e seus benefícios para a saúde ${ }^{(60,76,77)}$, em especial em nações em desenvolvimento, onde a distância costuma ser maior. No entanto há diversos grupos de interesse na sociedade, todos merecedores de voz, o que potencializa a dificuldade de gerir as cidades. Neste contexto, no meu entendimento, e também de meu orientador, a decisão política deveria ser baseada por valores que passam pela compreensão de qual é o bem maior. Entendemos que a qualidade de vida e a dignidade humana da grande maioria da população poderia ser o valor norteador de todas as políticas urbanas. Este valor está alinhado com o que outros cientistas que estudam meio ambiente e qualidade de vida tem proposto em âmbito internacional ${ }^{(35)}$. O Programa USP Cidades Globais pode ser um instrumento importante para verificar possibilidades da aplicação desses valores na prática. Ademais, se considerarmos a teoria de sistemas complexos e propriedades emergentes proposta pelo Programa para melhorar a qualidade de vida dos paulistanos, citada anteriormente nesta discussão, a inclusão de direitos humanos como um valor orientador de políticas públicas foi uma propriedade emergente que surgiu do conjunto de artigos que compões esta tese. 


\section{CONCLUSÃO}

A partir dos oito manuscritos apresentados nesta tese, concluímos que é possível produzir artigos científicos de bom nível ${ }^{*}$ que, ao mesmo tempo, integrem diferentes áreas de conhecimento e orientem formadores de opinião, gestores públicos e órgãos legislativos desejosos de estimular políticas voltadas para a promoção da saúde e qualidade de vida.

\footnotetext{
* Definidos para fins deste estudo como aqueles publicados em periódicos que utilizam análise por pares.
} 


\section{ANEXOS}

Anexo A.

Aprovação do Comitê de Ética em Pesquisa da Faculdade de Medicina da

Universidade de São Paulo.

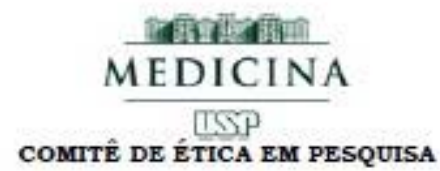

APROVAÇÃO

- comitê de Ética em Pesquisa da Faculdade de Medicina da Universidade de São Paulo, em sessão de 06/06/2012, APROVOU o Protocolo de Pesquisa n0 162/12 intitulado: "ESTUDO DA POLUIÇÃo ATMOSFÉRICA NO MUNDO A PARTIR DA RELAÇÃo ENTRE CONCENTRAÇÃo GLOBAL DE MATERLAI PARTICULADO, PRODUTO INTERNO ERUTO PER CAPITA, PRODUÇÃo CIENTÍfICA SOBRE POLUIÇÃo ATMOSFÉRICA E DIVULGAÇÃO DO CONHECIMENTO CIENTÍFICO SOBRE POLUIÇÃo ATMOSFÉRICA." apresentado pelo Departamento de PATOLOGLA

Cabe ao pesquisador elaborar e apresentar ao CEP-FMUSP, os relatórios parciais e final sobre a pesquisa (Resolução do Consellho Nacional de Saúde n0 196, de 10/10/1996, inciso IX.2, letra "c).

Pesquisador (a) Responsável: Paulo Hilário Nascimento Saldiva Pesquisador (a) Executante: Lais Fajersztajn

CEP-FMUSP, 12 de Junho de 2012.

$$
\begin{aligned}
& \text { PChamann. } \\
& \text { Prof. Dr. Roger Chammas } \\
& \text { Coordenador } \\
& \text { Comitê de Ética em Pesquisa }
\end{aligned}
$$

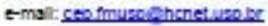


Anexo B.

Material suplementar referente ao artigo de revisão sistemática em processo de submissão apresentado na seção de resultados (Seção de Resultados, item 4.3)

\section{Supplemental Material}

Short-term effects of $\mathbf{P M}_{2.5}$ on daily health events in Latin America: a systematic review and meta-analysis.

Laís Fajersztajn, Paulo Saldiva, Luiz Alberto Amador Pereira, Victor Figueiredo Leite, Anna Maria Buehler

Table of Contents

S1. Search strategy

S2. Studies excluded by reason

S3. Association measurements conversion procedures

S4. References.

S1. Search strategy

Search strategy used at Pubmed, Scopus, Web of Science, Cochrane and Embase databases:

(((("Air Pollution"[Mesh] OR Air Pollution OR Air Pollutions OR Pollution, Air

OR Pollutions, Air OR "Particulate Matter"[Mesh] OR Airborne Particulate Matter OR Particulate Matter, Airborne OR Air Pollutants, Particulate OR Particulate Air Pollutants OR Pollutants, Particulate Air OR Ambient Particulate 
Matter OR Particulate Matter, Ambient OR PM 10)) AND ("Latin America"[Mesh] OR Latin America OR Argentina OR Barbados OR Belize OR Bolivia OR Brazil OR Chile OR Colombia OR Costa Rica OR Cuba OR Dominican Republic OR Ecuador OR El Salvador OR Guatemala OR Guyana OR Haiti OR Honduras OR Jamaica OR Mexico Or Nicaragua OR Panama OR Paraguay OR Peru OR Suriname OR Trinidad and Tobago OR Uruguay OR Venezuela))) AND (“Hospitalization”[Mesh] OR Hospitalization* OR hospital admission* OR emergency room visit* OR "Mortality"[Mesh] OR Mortality)

Search strategy used at Lilacs database:

Search included Decs (Health Sciences Descriptors) terms and was performed in English, Portuguese and Spanish languages, as described below:

(tw:(poluição do ar OR contaminación del aire OR air pollution)) OR (tw: material particulado OR MP10 OR particulate matter)) AND (tw: (mortalidade OR mortalidad OR mortality OR hospitalization OR admissão hospitalar OR admisión hospitalar OR emergency room visits $\mathrm{OR}$ emergência $\mathrm{OR}$ emergencia)) AND (instance:"regional")

S2. Studies excluded of the review by reason.

\begin{tabular}{lll}
\hline \multicolumn{2}{c}{ Did not meet eligibility criteria $(\mathrm{n}=153)$} & \\
\hline \multicolumn{2}{c}{ Study design and period evaluated $(\mathrm{n}=36)$} & Paraiso and Gouveia 2015 \\
\hline Amancio et al. 2012 & Duchiade 1992 & Silva et al. 2012 \\
Anenberg et al. 2011 & Filleul et al. 2001 & Prieto et al. 2007 \\
Avendaño C et al. 1999 & Garcia-Reynoso et al. 2007 & Ribeiro and Cardoso 2003 \\
Avendaño C et al. 2003 & Goncalves et al. 2005 & Riguera et al. 2011 \\
Bell et al. 2011 & Hernández-Cadena et al. & Rosa et al. 2008 \\
Botter et al. 2002 & 2007 & Silva et al. 2010 \\
Bueno et al. 2010 & Mascarenhas et al. 2008 & Silva and Ribeiro 2012 \\
Carneseca et al. 2012 & Castro and Neria 2003 & Silva et al. 2014 \\
Castro et al. 2007 & Muñoz et al. 2009 & Steven et al. 2008 \\
Castro et al. 2010 & Nascimento and Medeiros & \\
\hline
\end{tabular}




\begin{tabular}{|c|c|c|}
\hline $\begin{array}{l}\text { Chang et al. } 2004 \\
\text { Cifuentes et al. } 2001 \\
\text { Duchiade and Beltrao } 1992\end{array}$ & $\begin{array}{l}2012 \\
\text { Nicolella and Belluzzo } 2015 \\
\text { Oliveira et al. } 2012\end{array}$ & $\begin{array}{l}\text { Telez-Rojo et al. } 2001 \\
\text { Coutinho et al. } 2015\end{array}$ \\
\hline \begin{tabular}{l}
\multicolumn{2}{c}{ Exposure characteristics (n } \\
Adamkiewicz et al. 2001 \\
Alencar and Santos 2014 \\
Amancio and Nascimento \\
2012 \\
Amancio and Nascimento \\
2014 \\
Amarillo and Carreras 2012 \\
Andrade Filho et al. 2013 \\
Arbex et al. 2000 \\
Arbex et al. 2007 \\
Arbex et al. 2009 \\
Arbex et al. 2010 \\
Arbex et al. 2014 \\
Bakonyi et al. 2004 \\
Bell et al. 2006 \\
Blanco-Becerra et al. $2014 b$ \\
BorjaAburto et al. 1997 \\
Braga et al. 2001 \\
Braga et al. 2007 \\
Bravo and Bell 2011 \\
Cançado et al. 2006 \\
Carbajal-Arroyo et al. 2011 \\
Conceicao et al. 2001 \\
Farhat et al. 2005
\end{tabular} & $\begin{array}{l}\text { Freitas et al. 2004 } \\
\text { Daumas et al. } 2004 \\
\text { Diaz-Robles et al. } 2015 \\
\text { Gavinier and Nascimento } \\
2014 \\
\text { Gouveia and Fletcher 2000a } \\
\text { Gouveia and Fletcher 2000b } \\
\text { Gouveia et al. } 2006 \\
\text { Gurjar et al. } 2010 \\
\text { Habermann and Gouveia } \\
\text { 2012 } \\
\text { Hernández-Cadena et al. } \\
\text { 2000 } \\
\text { Hernández-Cadena et al. } \\
\text { 2007 } \\
\text { Ignotti et al. 2010 } \\
\text { Lin et al. 1999 } \\
\text { Lin et al. 2003 } \\
\text { Mardones et al. 2015 } \\
\text { Martins et al. 2002a } \\
\text { Martins et al. 2002b } \\
\text { Melgar-Paniagua et al. } 2013 \\
\text { Moura et al. 2009 } \\
\text { Naumova et al. 2007 }\end{array}$ & $\begin{array}{l}\text { Nardocci et al. } 2013 \\
\text { Nascimento et al. } 2006 \\
\text { Nascimento et al. } 2012 \\
\text { Nascimento and Francisco } \\
2013 \\
\text { Negrisoli and Nascimento } \\
2013 \\
\text { O'Neill et al. } 2006 \\
\text { O'Neill et al. } 2004 \\
\text { O'Neill et al. } 2008 \\
\text { Ostro et al. } 1996 \\
\text { Pinheiro et al. } 2014 \\
\text { Romero-Placeres et al. } 2004 \\
\text { Romieu et al. } 2004 \\
\text { Romieu et al. } 2012 \\
\text { Saldiva et al. } 1994 \\
\text { Saldiva et al. } 1995 \\
\text { Sanhueza et al. } 2006 \\
\text { Sanhueza et al. } 2009 \\
\text { Santos et al. } 2008 \\
\text { Souza et al. } 2014 \\
\text { Tellez-Rojo et al. } 1997\end{array}$ \\
\hline $\begin{array}{l}\text { Outcome characteristics (n } \\
\text { Barbosa et al. } 2015 \\
\text { Cakmak et al. } 2010 \\
\text { Carmo et al. } 2010 \\
\text { Dales et al. } 2009 \\
\text { Dales et al. } 2012\end{array}$ & $\begin{array}{l}\text { Diaz-Robles et al. } 2014 \\
\text { Lin et al. } 2004 \\
\text { Ostro et al. } 1999 \\
\text { Pereira et al. } 1998 \\
\text { Pereira Filho et al. } 2008\end{array}$ & $\begin{array}{l}\text { Sousa et al. 2012a } \\
\text { Vera et al. } 2007 \\
\text { Vera et al. } 2008 \\
\text { Zamorano et al. } 2003\end{array}$ \\
\hline $\begin{array}{l}\text { Population characteristics }( \\
\text { Darrow et al. } 2011 \\
\text { Galan et al. } 2003\end{array}$ & Gittins et al. 2013 & Murray and Lipfert 2012 \\
\hline \begin{tabular}{l}
\multicolumn{1}{c}{ Association measure chara } \\
Blanco-Becerra et al. 2014a \\
Braga et al. 1999 \\
Cakmak et al. 2007 \\
Cakmak et al. 2009b \\
Cakmak et al. 2009a \\
Cakmak et al. 2011 \\
Carmo et al. 2013 \\
Cendon et al. 2006 \\
Cifuentes et al. 2000 \\
Cook et al. 1998 \\
Franck et al. 2015
\end{tabular} & $\begin{array}{l}\text { istics }(\mathrm{n}=33) \\
\text { Franck et al. } 2014 \\
\text { Ghement et al. } 2007 \\
\text { Gonçalves et al. } 2007 \\
\text { Gouveia et al. } 2003 \\
\text { Grass and Cane } 2008 \\
\text { Gutierrez 2015 } \\
\text { Jasinski et al. } 2011 \\
\text { Ilabaca et al. } 1999 \\
\text { Leiva et. Al 2013 } \\
\text { Martins et al. } 2004 \\
\text { Martins et al. } 2006\end{array}$ & $\begin{array}{l}\text { Moura et al. } 2008 \\
\text { Nascimento } 2011 \\
\text { Nunes et al. } 2013 \\
\text { Oliveira et al. } 2011 \\
\text { Reyna et al. } 2013 \\
\text { Romero-Lankao et al. } 2013 \\
\text { Salinas and Vega } 1995 \\
\text { Sousa et al. 2012b } \\
\text { Tellez-Rojo et al. } 2000 \\
\text { Vera and Cifuentes } 2009 \\
\text { Yanagi et al. } 2012\end{array}$ \\
\hline \multicolumn{3}{|c|}{ Studies which aim was to evaluate the effect of temperature $(n=3)$} \\
\hline
\end{tabular}




\begin{tabular}{|c|c|c|}
\hline \multicolumn{3}{|c|}{ Full text could not be retrieved $(n=5)$} \\
\hline Giraldo 2008 & Penna and Duchiade 1991b & Target and Cabanes 2005 \\
\hline Penna and Duchiade 1991a & Sanhueza et al. 2008 & \\
\hline \multicolumn{3}{|c|}{ Duplicates (conference papers published as a full paper retrieved by the search) $(n=3)$} \\
\hline Freitas et al. 2001 & Martins et al. 2001 & Tellez-Rojo et al. 1999 \\
\hline \multicolumn{3}{|l|}{ Overlap of populations $(\mathrm{n}=1)$} \\
\hline Castillegos et al. 2000 & & \\
\hline
\end{tabular}

S3. Association measurements conversion procedures

$$
\begin{aligned}
& \mathrm{RR}=(\mathrm{RPC} / 100)+1 \\
& \mathrm{RR}=((\exp (ß \times \mathrm{vp}) \\
& \beta=\operatorname{LnRR} / \mathrm{vp} \\
& \mathrm{e}=(\ln (\text { upper } \mathrm{CI})-((\mathrm{x} \mathrm{vp})) / 1,96 \times \mathrm{vp}
\end{aligned}
$$

where RR is the relative risk, $B$ is the coefficient regression, $v p$ is the variation in pollutant concentration, e is the error and CI is the Confidence Interval

\section{S4. References}

Adamkiewicz G, Adamkiewicz G, Braga ALF, Schwartz J, Zanobetti A, Dockery DW. 2001. Effect of ambient air pollution on adult asthma hospital admissions in Sao Paulo, Brazil. Epidemiology 12: S75-S75.

Alencar AP, Santos BR. 2014. Association of pollution with quantiles and expectations of the hospitalization rate of elderly people by respiratory diseases in the city of Sao Paulo, Brazil. Environmetrics 25:165-171; doi:10.1002/env.2274.

Amancio CT, Nascimento LF. 2014. Environmental pollution and deaths due to stroke in a city with low levels of air pollution: ecological time series study. Sao Paulo Med. J. 132:353-358; doi:10.1590/1516-3180.2014.1326733.

Amancio CT, Nascimento LFC. 2012. Association of sulfur dioxide exposure with circulatory system deaths in a medium-sized city in Brazil. Brazilian J. Med. Biol. Res. 45:1080-1085; doi:10.1590/S0100-879X2012007500131.

Amancio CT, Nascimento LFC, Amancio TT. 2012. Environmental pollutants and odds of hospitalization for asthma in children - São José Dos Campos, Brazil, in the years 2004-2005. J. Hum. Growth Dev. 22: 202-208.

Amarillo AC, Carreras HA. 2012. The effect of airborne particles and weather conditions on pediatric respiratory infections in Cordoba, Argentine. Environ. Pollut. 170:217-221; doi:10.1016/j.envpol.2012.07.005.

Andrade Filho VS de, Artaxo P, Hacon S, Carmo CN do, Cirino G. 2013. Aerossois de queimadas e doencas respiratorias em criancas, Manaus, Brasil Manaus, Northern Brazil. Rev. Saude Publica 47:239-247; doi:10.1590/S0034-8910.2013047004011.

Anenberg SC, Talgo K, Arunachalam S, Dolwick P, Jang C, West JJ. 2011. Impacts of global, regional, and sectoral black carbon emission reductions on surface air quality and human mortality. Atmos. 
Chem. Phys. 11:7253-7267; doi:10.5194/acp-11-7253-2011.

Arbex MA, Amador Pereira LA, Carvalho-Oliveira R, do Nascimento Saldiva PH, Ferreira Braga AL. 2014. The effect of air pollution on pneumonia-related emergency department visits in a region of extensive sugar cane plantations: a 30-month time-series study. J. Epidemiol. Community Health 68:669-674; doi:10.1136/jech-2013-203709.

Arbex MA, Bohm GM, Saldiva PHN, Conceicao GMS, Pope AC, Braga ALF. 2000. Assessment of the effects of sugar cane plantation burning on daily counts of inhalation therapy. J. Air Waste Manage. Assoc. 50: 1745-1749.

Arbex MA, De Souza Conceição GM, Cendon SP, Arbex FF, Lopes AC, Moysés EP, et al. 2009. Urban air pollution and chronic obstructive pulmonary disease-related emergency department visits. J. Epidemiol. Community Health 63:777-783; doi:10.1136/jech.2008.078360.

Arbex MA, Martins LC, de Oliveira RC, Pereira LAA, Arbex FF, Cancado JED, et al. 2007. Air pollution from biomass burning and asthma hospital admissions in a sugar cane plantation area in Brazil. J. Epidemiol. Community Health 61:395-400; doi:10.1136/jech.2005.044743.

Arbex MA, Saldiva PHN, Pereira LAA, Braga ALF. 2010. Impact of outdoor biomass air pollution on hypertension hospital admissions. J. Epidemiol. Community Health 64:573-579; doi:10.1136/jech.2009.094342.

Avendaño C LF, Céspedes L A, Stecher G X, Palomino M MA. 1999. Influence of respiratory viruses, cold weather and air pollution in the incidence of lower respiratory tract infections in infants children . Rev. Med. Chil. 127: 1073-1078.

Avendaño C LF, Parra V J, Padilla V C, Palomino M MA, Avendano CLF, Parra VJ, et al. 2003. The influence of respiratory virus infections and environmental conditions on pediatric health care demand during winter-2002 in Santiago, Chile . Rev. Med. Chil. 131: 902-908.

Bakonyi SMC, Danni-Oliveira IM, Martins LC, Braga ALF. 2004. Air pollution and respiratory diseases among children in the city of Curitiba, Brazil. Rev. Saude Publica 38:695-700; doi:10.1590/S003489102004000500012.

Barbosa SMM, Farhat SCL, Martins LC, Pereira LAA, Saldiva PHN, Zanobetti A, et al. 2015. Air pollution and children's health: sickle cell disease. Cad. Saude Publica 31:265-275; doi:10.1590/0102-311X00013214.

Bell ML, Cifuentes LA, Davis DL, Cushing E, Telles AG, Gouveia N. 2011. Environmental health indicators and a case study of air pollution in Latin American cities. Environ. Res. 111:57-66; doi:10.1016/j.envres.2010.10.005.

Bell ML, Davis DL, Gouveia N, Borja-Aburto VH, Cifuentes LA. 2006. The avoidable health effects of air pollution in three Latin American cities: Santiago, Sao Paulo, and Mexico City. Environ. Res. 100:431-440; doi:10.1016/j.envres.2005.08.002.

Blanco-Becerra LC, Miranda-Soberanis V, Barraza-Villarreal A, Junger W, Hurtado-Díaz M, Romieu I, et al. 2014a. Effect of socioeconomic status on the association between air pollution and mortality in Bogota, Colombia. Salud Publica Mex. 56: 371-378.

Blanco-Becerra LC, Miranda-Soberanis V, Hernández-Cadena L, Barraza-Villarreal A, Junger W, Hurtado-Díaz M, et al. 2014b. Effect of particulate matter less than $10 \mu \mathrm{m}$ (PM10) on mortality in Bogota, Colombia: a time-series analysis, 1998-2006 en Bogotá, Colombia: un análisis de series de tiempo 1998-2006. Salud Publica Mex. 56: 363-370.

BorjaAburto VH, Loomis DP, Bangdiwala SI, Shy CM, RasconPacheco RA, Borja-Aburto VH, et al. 1997. Ozone, suspended particulates, and daily mortality in Mexico City. Am. J. Epidemiol. 145: $258-268$.

Botter DA, Jorgensen B, Perese AAQ. 2002. A longitudinal study of mortality and air pollution for Sao Paulo, Brazil. J. Expo. Anal. Environ. Epidemiol. 12:335-343; doi:10.1038/sj.jea.7500234.

Braga AL., Conceição, G.M.S., Conceição GMS, L.A.A. P, Kishi HS, Pereira JCR, Andrade MF, et al. 1999. Air Pollution and Pediatric Respiratory Hospital Admissions in São Paulo, Brazil. J. Environ. Med 1: 95-102.

Braga ALF, Pereira LAA, Procópio M, André PA de, Saldiva PH do N. 2007. Associação entre poluição atmosférica e doenças respiratórias e cardiovasculares na cidade de Itabira, Minas Gerais, Brasil. Cad Saude Publica 23: S570-S578.

Braga ALF, Saldiva PHN, Pereira LAA, Menezes JJC, Conceição GMS, Lin CA, et al. 2001. Health effects of air pollution exposure on children and adolescents in São Paulo, Brazil. Pediatr. Pulmonol. 31: 106-113.

Bravo MA, Bell ML. 2011. Spatial Heterogeneity of PM10 and O-3 in Sao Paulo, Brazil, and Implications for Human Health Studies. J. Air Waste Manage. Assoc. 61:69-77; doi:10.3155/10473289.61.1.69. 
Bueno FF, Fonseca AR, Braga FA, Miranda PSC. 2010. Air quality and number of hospital admissions for respiratory disease among children in the city of Divinópolis, Brazil . Acta Sci. - Heal. Sci. 32:185-189; doi:10.4025/actascihealthsci.v32i2.7344.

Cakmak S, Dales RE, Vidal CB. 2007. Air pollution and mortality in Chile: Susceptibility among the elderly. Environ. Health Perspect. 115:524-527; doi:10.1289/ehp.9567.

Cakmak S, Dales RE, Gultekin T, Vidal CB, Farnendaz M, Rubio MA, et al. 2009a. Components of Particulate Air Pollution and Emergency Department Visits in Chile. Arch. Environ. Occup. Health 64: 148-155.

Cakmak S, Dales RE, Vida CB. 2009b. Components of particulate air pollution and mortality in Chile. Int. J. Occup. Environ. Health 15: 152-158.

Cakmak S, Dales RE, Vidal CB. 2010. Air pollution and hospitalization for epilepsy in Chile. Environ. Int. 36:501-505; doi:10.1016/j.envint.2010.03.008.

Cakmak S, Dales RE, Angelica Rubio M, Blanco Vidal C. 2011. The risk of dying on days of higher air pollution among the socially disadvantaged elderly. Environ. Res. 111:388-393; doi:10.1016/j.envres.2011.01.003.

Cançado JED, Saldiva PHN, Pereira LAA, Lara LBLSLBLS, Artaxo P, Martinelli LA, et al. 2006. The impact of sugar cane-burning emissions on the respiratory system of children and the elderly. Environ. Health Perspect. 114:725-729; doi:10.1289/ehp.8485.

Carbajal-Arroyo L, Miranda-Soberanis V, Medina-Ramon M, Rojas-Bracho L, Tzintzun G, SolisGutierrez P, et al. 2011. Effect of PM10 and O-3 on infant mortality among residents in the Mexico City Metropolitan Area: a case-crossover analysis, 1997-2005. J. Epidemiol. Community Health 65:715-721; doi:10.1136/jech.2009.101212.

Carmo CN, Alves MB, Hacon SS. 2013. Impact of biomass burning and weather conditions on children's health in a city of Western Amazon region. Air Qual. Atmos. Heal. 6:517-525; doi:10.1007/s11869-012-0191-6.

Carmo CN, Hacon S, Longo KM, Freitas S, Ignotti E, de Leon AP, et al. 2010. Association between particulate matter from biomass burning and respiratory diseases in the southern region of the Brazilian Amazon. Rev. Panam. Salud Publica-Pan Am. J. Public Heal. 27: 10-16.

Carneseca EC, Achcar JA, Martinez EZ. 2012. Association between particulate matter air pollution and monthly inhalation and nebulization procedures in Ribeirao Preto, Sao Paulo State, Brazil. Cad. Saude Publica 28: 1591-1598.

Carreras H, Zanobetti A, Koutrakis P. 2015. Effect of daily temperature range on respiratory health in Argentina and its modification by impaired socio-economic conditions and $\mathrm{PM}<\mathrm{inf}>10<$ inf $>$ exposures. Environ. Pollut. 206:175-182; doi:10.1016/j.envpol.2015.06.037.

Castillejos M, Borja-Aburto VH, Dockery DW, Gold DR, Loomis D. 2000. Airborne coarse particles and mortality. Inhal. Toxicol. 12: 61-72.

Castro HA de, Hacon S, Argento R, Junger WL, Mello CF de, Castiglioni Junior N, et al. 2007. Air pollution and respiratory diseases in the Municipality of Vitoria, Espirito Santo State, Brazil. Cad. Saude Publica 23 Suppl 4: S630-42.

Castro HM, Neria JP. 2003. Atmospheric pollution in the Southern Mexico City Metropolitan Area. Rev. del Inst. Nac. Enfermedades Respir. 16: 48-53.

Castro P, Vera J, Cifuentes L, Wellenius G, Verdejo H, Sepúlveda L, et al. 2010. Polución por material particulado fino (PM 2,5) incrementa las hospitalizaciones por insuficiencia cardiaca hospitalization rate for congestive heart failure. Rev. Chil. Cardiol. 29:306-314; doi:10.4067/S071885602010000300004 .

Cendon S, Pereira LAA, Braga ALF, Conceicao GMS, Cury Junior A, Romaldini H, et al. 2006. Air pollution effects on myocardial infarction. Rev. Saude Publica 40:414-419; doi:/S003489102006000300008 .

Chang CL, Shipley M, Marmot M, Poulter N. 2004. Lower ambient temperature was associated with an increased risk of hospitalization for stroke and acute myocardial infarction in young women. J. Clin. Epidemiol. 57:749-757; doi:10.1016/j.jclinepi.2003.10.016.

Cifuentes L, Borja-Aburto VH, Gouveia N, Thurston G, Davis DL. 2001. Assessing the health benefits of urban air pollution reductions associated with climate change mitigation (2000-2020): Santiago, Sao Paulo, Mexico City, and New York City. Environ. Health Perspect. 109:419-425; doi: $10.2307 / 3434790$.

Cifuentes LA, Vega J, Kopfer K, Lave LB. 2000. Effect of the fine fraction of particulate matter versus the coarse mass and other pollutants on daily mortality in Santiago, Chile. J. Air Waste Manag. Assoc. 50: 1287-1298.

Conceicao GM, Miraglia SG, Kishi HS, Saldiva PH, Singer JM. 2001. Air pollution and child mortality: a 
time-series study in Sao Paulo, Brazil. Environ. Health Perspect. 109 Suppl : 347-350.

Cook A, Cullinan P, Ancic P, Newman Taylor AJ. 1998. Mortality and particulate air pollution in Santiago, Chile. Thorax 53.

Coutinho KMV, Rizol PMSR, Nascimento LFC, Medeiros APP de. 2015. Fuzzy model approach for estimating time of hospitalization due to cardiovascular diseases. Cien. Saude Colet. 20:2585-2590; doi:10.1590/1413-81232015208.19472014.

Dales RE, Cakmak S, Vidal CB. 2009. Air pollution and hospitalization for headache in Chile. Am. J. Epidemiol. 170:1057-1066; doi:10.1093/aje/kwp217.

Dales RE, Cakmak S, Vidal CB, Rubio MA. 2012. Air pollution and hospitalization for acute complications of diabetes in Chile. Environ. Int. 46:1-5; doi:10.1016/j.envint.2012.05.002.

Darrow L, Klein M, JA S, JA M, MJ S, SE S, et al. 2011. The use of alternative pollutant metrics in timeseries studies of ambient air pollution and respiratory emergency department visits. J Expo Sci Env. Epidemiol 21: 10-19.

Daumas RP, Mendonça GA, Ponce de León A. 2004. Air pollution and mortality in the elderly in Rio de Janeiro: a time-series analysis . Cad. saúde pública / Ministério da Saúde, Fundação Oswaldo Cruz, Esc. Nac. Saúde Pública 20: 311-319.

Diaz-Robles L, Cortes S, Vergara-Fernandez A, Carlos Ortega J. 2015. Short Term Health Effects of Particulate Matter: A Comparison between Wood Smoke and Multi-Source Polluted Urban Areas in Chile. Aerosol Air Qual. Res. 15:306-318; doi:10.4209/aaqr.2013.01.0316.

Diaz-Robles LA, Fu JS, Vergara-Fernandez A, Etcharren P, Schiappacasse LN, Reed GD, et al. 2014. Health risks caused by short term exposure to ultrafine particles generated by residential wood combustion: A case study of Temuco,Chile. Environ. Int. 66:174-181; doi:10.1016/j.envint.2014.01.017.

Duchiade MP. 1992. Infant and child mortality caused by pneumonia in the Rio de Janeiro metropolitan region, 1976-1986 . Rev. Bras. Estud. Popul. 9: 95-96.

Duchiade MP, Beltrao KI. 1992. Infant mortality by cause of death in the Rio de Janeiro metropolitan area, 1976-1986: association with socioeconomic, climatic and air pollution variables . Rev. Bras. Estud. Popul. 9: 115-137.

Farhat SCL, Paulo RLP, Shimoda TM, Conceicao GMS, Lin CA, Braga ALF, et al. 2005. Effect of air pollution on pediatric respiratory emergency room visits and hospital admissions. Braz. J. Med. Biol. Res. 38:227-235; doi:/S0100-879X2005000200011.

Filleul L, Vandentorren S, Baldi I, Tessier JF. 2001. Daily respiratory mortality and PM10 pollution in Mexico city [4]. Eur. Respir. J. 17:1055-1056; doi:10.1183/09031936.01.17510540.

Franck U, Leitte AM, Suppan P. 2015. Multifactorial airborne exposures and respiratory hospital admissions - The example of Santiago de Chile. Sci. Total Environ. 502:114-121; doi:10.1016/j.scitotenv.2014.08.093.

Franck U, Leitte AM, Suppan P. 2014. Multiple exposures to airborne pollutants and hospital admissions due to diseases of the circulatory system in Santiago de Chile. Sci. Total Environ. 468-469:746756; doi:10.1016/j.scitotenv.2013.08.088.

Freitas C, Bremner S, Gouveia NC, Preira LA, Saldiva PHN. 2001. Hospital admissions due to respiratory diseases in children and mortality in elderly people are positively associated with air pollution in Sao Paulo, Brazil. A time-series study from 1993 to 1997. Epidemiology 12: S87-S87.

Freitas C, Bremner SA, Gouveia N, Pereira LAA, Saldiva PHN. 2004. [Hospital admissions and mortality: association with air pollution in Sao Paulo, Brazil, 1993 to 1997]. Rev. Saude Publica 38:751-757; doi:/S0034-89102004000600001.

Galan I, Tobias A, Banegas JR, Aranguez E. 2003. Short-term effects of air pollution on daily asthma emergency room admissions. Eur. Respir. J. 22:802-808; doi:10.1183/09031936.03.00013003.

Garcia-Reynoso, A. G, Cintora-Juarez M. 2007. Risk assessment for criteria pollutants and formaldehyde in Mexico City. Rev. Int. Contam. Ambient. 23: 169-175.

Gavinier S, Nascimento LFC. 2014. Air pollutants and hospital admissions due to stroke. Rev. Ambient. Agua 9:390-401; doi:10.4136/ambi-agua.1318.

Ghement IR, Heckman NE, Petkau AJ. 2007. Seasonal confounding and residual correlation in analyses of health effects of air pollution. Environmetrics 18:375-394; doi:10.1002/env.814.

Giraldo SE. 2008. Air pollution and lower respiratory illness in children. Int. Pediatr. 23: 43-44.

Gittins M, McNamee R, Carder M, Beverland I, Agius RM. 2013. Has the short-term effect of black smoke exposure on pneumonia mortality been underestimated because hospitalisation is ignored: findings from a case-crossover study. Environ. Heal. 12; doi:10.1186/1476-069X-12-97.

Gonçalves FLT, Braun S, Silva Dias PL, Sharovsky R, Goncalves FLT, Braun S, et al. 2007. Influences of the weather and air pollutants on cardiovascular disease in the metropolitan area of São Paulo. 
Environ. Res. 104:275-281; doi:10.1016/j.envres.2007.01.004.

Goncalves FLT, Carvalho LM V, Conde FC, Latorre M, Saldiva PHN, Braga ALF. 2005. The effects of air pollution and meteorological parameters on respiratory morbidity during the summer in Sao Paulo City. Environ. Int. 31:343-349; doi:10.1016/j.envint.2004.08.004.

Gouveia N, Fletcher T. 2000a. Respiratory diseases in children and outdoor air pollution in Sao Paulo, Brazil: a time series analysis. Occup. Environ. Med. 57: 477-483.

Gouveia N, Fletcher T. 2000b. Time series analysis of air pollution and mortality: effects by cause, age and socioeconomic status. J. Epidemiol. Community Health 54:750-755; doi:10.1136/jech.54.10.750.

Gouveia N, Freitas CU de, Martins LC, Marcilio IO. 2006. Hospitalizações por causas respiratórias e cardiovasculares associadas à contaminação atmosférica no Município de São Paulo, Brasil pollution in the city of São Paulo, Brazil. Cad. Saude Publica 22: 2669-2677.

Gouveia N, Hajat S, Armstrong B. 2003. Socioeconomic differentials in the temperature-mortality relationship in São Paulo, Brazil. Int. J. Epidemiol. 32: 390-397.

Grass D, Cane M. 2008. The effects of weather and air pollution on cardiovascular and respiratory mortality in Santiago, Chile, during the winters of 1988-1996. Int. J. Climatol. 28:1113-1126; doi:10.1002/joc. 1592 .

Gurjar BR, Jain A, Sharma A, Agarwal A, Gupta P, Nagpure AS, et al. 2010. Human health risks in megacities due to air pollution. Atmos. Environ. 44:4606-4613; doi:10.1016/j.atmosenv.2010.08.011.

Gutierrez E. 2015. Air quality and infant mortality in Mexico: evidence from variation in pollution concentrations caused by the usage of small-scale power plants. J. Popul. Econ. 28:1181-1207; doi:10.1007/s00148-015-0539-y.

Habermann M, Gouveia N. 2012. Motor vehicle traffic and cardiovascular mortality in male adults. Rev. Saude Publica 46:26-33; doi:10.1590/S0034-89102011005000079.

Hernández-Cadena L, Barraza-Villarreal A, Ramírez-Aguilar M, Moreno-Macías H, Miller P, CarbajalArroyo LA, et al. 2007. Infant morbidity caused by respiratory diseases and its relation with the air pollution in Juarez City, Chihuahua, Mexico . Salud Publica Mex. 49: 27-36.

Hernández-Cadena L, Téllez-Rojo MM, Sanín-Aguirre LH, Lacasaña-Navarro M, Campos A, Romieu I, et al. 2000. Relationship between emergency room visits for respiratory disease and atmospheric pollution in Ciudad Juarez, Chihuahua. Salud Publica Mex. 42:288-297; doi:10.1590/S003636342000000400003.

Ignotti E, Valente JG, Longo KM, Freitas SR, Hacon S de S, Netto PA. 2010. Impact on human health of particulate matter emitted from burnings in the Brazilian Amazon region. Rev. Saude Publica 44: $121-130$.

Ilabaca M, Olaeta I, Campos E, Villaire J, Tellez-Rojo MM, Romieu I. 1999. Association between levels of fine particulate and emergency visits for pneumonia and other respiratory illnesses among children in Santiago, Chile. J. Air Waste Manage. Assoc. 49: 154-163.

Jasinski R, Pereira LAA, Braga ALF. 2011. [Air pollution and pediatric hospital admissions due to respiratory diseases in Cubatao, Sao Paulo State, Brazil, from 1997 to 2004]. Cad. Saude Publica 27: 2242-2252.

Leiva G MA, Santibanez DA, Ibarra E S, Matus C P, Seguel R, Leiva MA, et al. 2013. A five-year study of particulate matter (PM2.5) and cerebrovascular diseases. Environ. Pollut. 181:1-6; doi:10.1016/j.envpol.2013.05.057.

Lin CA, Amador Pereira LA, de Souza Conceicao GM, Kishi HS, Milani RJ, Ferreira Braga AL, et al. 2003. Association between air pollution and ischemic cardiovascular emergency room visits. Environ. Res. 92: 57-63.

Lin CA, Martins MA, Farhat SCL, Pope CA, Conceicao GMS, Anastacio VM, et al. 1999. Air pollution and respiratory illness of children in Sao Paulo, Brazil. Paediatr. Perinat. Epidemiol. 13: 475-488.

Lin S, Hwang SA, Pantea C, Kielb C, Fitzgerald E. 2004. Childhood asthma hospitalizations and ambient air sulfur dioxide concentrations in Bronx County, New York. Arch. Environ. Health 59:266-275; doi:10.3200/AEOH.59.5.266-275.

Mardones C, Saavedra A, Jimenez J. 2015. [Health and economic benefits of reducing 10 microm particulate matter (PM10) in Metropolitan Area of Concepcion, Chile]. Rev. Med. Chil. 143:475483; doi:10.4067/S0034-98872015000400009.

Martins LC, Latorre M, Braga ALF, Cardoso MRA, Goncalves FLT, Saldiva PHN, et al. 2001. Air pollution and emergency room visits for pneumonia and influenza in elderly people in Sao Paulo City - Brazil. Epidemiology 12: S50-S50.

Martins LC, Latorre M do RD de O, Cardoso MRA, Goncalves FLT, Saldiva PHN, Braga ALF. $2002 \mathrm{a}$. 
[Air pollution and emergency room visits due to pneumonia and influenza in Sao Paulo, Brazil]. Rev. Saude Publica 36: 88-94.

Martins LC, Latorre M do RD de O, Saldiva PH do N, Braga ALF, Conceịão Martins L, De Oliveira Latorre MDRD, et al. 2002b. Air pollution and emergency room visits due to chronic lower respiratory diseases in the elderly: An ecological time-series study in São Paulo, Brazil. J. Occup. Environ. Med. 44: 622-627.

Martins LC, Pereira LAA, Lin CA, Santos UP, Prioli G, Luiz O do C, et al. 2006. The effects of air pollution on cardiovascular diseases: lag structures. Rev. Saude Publica 40: 677-683.

Martins MCH, Fatigati FL, Vespoli TC, Martins LC, Pereira LAA, Martins MA, et al. 2004. Influence of socioeconomic conditions on air pollution adverse health effects in elderly people: an analysis of six regions in Sao Paulo, Brazil. J. Epidemiol. Community Health 58:41-46; doi:10.1136/jech.58.1.41.

Mascarenhas MDM, Vieira LC, Lanzieri TM, Leal APPR, Duarte AF, Hatch DL. 2008. Poluição atmosférica devida à queima de biomassa florestal e atendimentos de emergência por doença respiratória em Rio Branco, Brasil - Setembro, 2005 room visits in Rio Branco, Brazil - September, 2005. J. Bras. Pneumol. 34:42-46; doi:10.1590/S1806-37132008000100008.

Melgar-Paniagua EM, Vega-Rangel E, Del Razo LM, Lucho-Constantino CA, Rothenberg SJ, De Vizcaya-Ruiz A. 2013. Distributed lag associations between respiratory illnesses and mortality with suspended particle concentration in Tula, a highly polluted industrial region in Central Mexico. Int. Arch. Occup. Environ. Health 86:321-332; doi:10.1007/s00420-012-0768-2.

Moura M, Junger WL, Mendonca GA e S, De Leon AP. 2008. Air quality and acute respiratory disorders in children. Rev. Saude Publica 42:503-511; doi:10.1590/S0034-89102008005000016.

Moura M, Junger WL, Mendonça GAES, De Leon AP. 2009. Air quality and emergency pediatric care for symptoms of bronchial obstruction categorized by age bracket in Rio de Janeiro, Brazil. Cad. Saude Publica 25: 635-644.

Muñoz F, Carvalho MS, Munoz F, Carvalho MS. 2009. Effect of exposure time to PM10 on emergency admissions for acute bronchitis. Cad. Saude Publica 25: 529-539.

Murray CJ, Lipfert FW. 2012. A new time-series methodology for estimating relationships between elderly frailty, remaining life expectancy, and ambient air quality. Inhal. Toxicol. 24:89-98; doi:10.3109/08958378.2011.638947.

Nardocci AC, Freitas CU de, Ponce de Leon ACM, Junger WL, Gouveia N da C. 2013. Poluição do ar e doenças respiratórias e cardiovasculares: estudo de séries temporais em Cubatão, São Paulo, Brasil study in Cubatão, São Paulo State, Brazil cardiovasculares: estudio de series temporales en Cubatão, São Paulo, Brasil. Cad. Saude Publica 29:1867-1876; doi:10.1590/0102-311X00150012.

Nascimento L, Francisco, JB, Patto M, Antunes A. 2012. Environmental pollutants and stroke-related hospital admissions. Cad. Saude Publica 28: 1319-1324.

Nascimento L, Francisco J. 2013. Particulate matter and hospital admission due to arterial hypertension in a medium-sized Brazilian city. Cad. Saude Publica 29:1565-1571; doi:10.1590/0102$311 X 00127612$.

Nascimento LFC. 2011. Air pollution and cardiovascular hospital admissions in a medium-sized city in Sao Paulo State, Brazil. Braz. J. Med. Biol. Res. 44: 720-724.

Nascimento LFC, Medeiros APP de. 2012. Admissions due to pneumonia and biomass burning: a spatial approach. J. Pediatr. (Rio. J). 88:177-183; doi:10.2223/JPED.2161.

Nascimento LFC, Pereira LAA, Braga ALF, Modolo MCC, Carvalho JAJ. 2006. [Effects of air pollution on children's health in a city in Southeastern Brazil]. Rev. Saude Publica 40:77-82; doi:/S003489102006000100013.

Naumova EN, Yepes H, Griffiths JK, Sempertegui F, Khurana G, Jagai JS, et al. 2007. Emergency room visits for respiratory conditions in children increased after Guagua Pichincha volcanic eruptions in April 2000 in Quito, Ecuador observational study: time series analysis. Environ. Health 6:21; doi:10.1186/1476-069X-6-21.

Negrisoli J, Nascimento LFC. 2013. Atmospheric pollutants and hospital admissions due to pneumonia in children . Rev. Paul. Pediatr. 31:501-506; doi:10.1590/S0103-05822013000400013.

Nicolella AC, Belluzzo W. 2015. The effect of reducing the pre-harvest burning of sugar cane on respiratory health in Brazil. Environ. Dev. Econ. 20:127-140; doi:10.1017/S1355770X14000096.

Nunes KVR, Ignotti E, Hacon SS. 2013. Circulatory disease mortality rates in the elderly and exposure to PM2.5 generated by biomass burning in the Brazilian Amazon in 2005 . Cad. Saude Publica 29: 589-598.

O’Neill M, Bell M, Ranjit N, Borja V, Cifuentes L, Gouveia N, et al. 2006. Air pollution, mortality and education in Mexico. Epidemiology 17:S339-S339; doi:10.1097/00001648-200611001-00898. 
O’Neill MS, Bell ML, Ranjit N, Cifuentes LA, Loomis D, Gouveia N, et al. 2008. Air pollution and mortality in latin America: The role of education. Epidemiology 19:810-819; doi:10.1097/EDE.0b013e3181816528.

O'Neill MS, Hajat S, Zanobetti A, Ramirez-Aguilar M, Schwartz J. 2005. Impact of control for air pollution and respiratory epidemics on the estimated associations of temperature and daily mortality. Int. J. Biometeorol. 50:121-129; doi:10.1007/s00484-005-0269-z.

O’Neill MS, Loomis D, Borja Aburto VH, Gold D, Hertz-Picciotto I, Castillejos M. 2004. Do associations between airborne particles and daily mortality in Mexico City differ by measurement method, region, or modeling strategy? J. Expo. Anal. Environ. Epidemiol. 14:429-439; doi:10.1038/sj.jea.7500341.

Oliveira B, Ignotti E, Artaxo P, Saldiva Ph, Junger W, Hacon S. 2012. Risk assessment of PM2.5 to child residents in Brazilian Amazon region with biofuel production. Environ. Heal. 11:64; doi:10.1186/1476-069X-11-64.

Oliveira M, Mattos I, Koifman S. 2011. Air Pollution and Respiratory Diseases Hospital Admissions: Sex-related Patterns in a Population Living Nearby a Steel Producing Plant in Brazil. Epidemiology 22:S226-S226; doi:10.1097/01.ede.0000392381.46591.31.

Ostro B, Sanchez JM, Aranda C, Eskeland GS. 1996. Air pollution and mortality: Results from a study of Santiago, Chile. J. Expo. Anal. Environ. Epidemiol. 6: 97-114.

Ostro BD, Eskeland GS, Sanchez JM, Feyzioglu T. 1999. Air pollution and health effects: A study of medical visits among children in Santiago, Chile. Environ. Health Perspect. 107: 69-73.

Paraiso MLS, Gouveia N. 2015. Health risks due to pre-harvesting sugarcane burning in são paulo state, Brazil . Rev. Bras. Epidemiol. 18:691; doi:10.1590/1980-5497201500030014.

Penna ML, Duchiade MP. 1991a. Air pollution and infant mortality from pneumonia in the Rio de Janeiro metropolitan area. Bull. Pan Am. Health Organ. 25: 47-54.

Penna MLF, Duchiade MP. 1991b. Air pollution and infant mortality due to pneumonia . Bol. - Of. Sanit. Panam. 110: 199-207.

Pereira Filho MA, Pereira LAA, Arbex FF, Arbex M, Conceicao GM, Santos UP, et al. 2008. Effect of air pollution on diabetes and cardiovascular diseases in São Paulo, Brazil. Braz J Med Biol Res 41: 526-532.

Pereira LAA, Loomis D, Conceição GMS, Braga ALF, Arcas RM, Kishi HS, et al. 1998. Association between air pollution and intrauterine mortality in Sao Paulo, Brazil. Environ. Health Perspect. 106: 325-329.

Pinheiro S de LL de A, Saldiva PHN, Schwartz J, Zanobetti A, de Araujo Pinheiro SLL, Saldiva PHN, et al. 2014. Isolated and synergistic effects of PM10 and average temperature on cardiovascular and respiratory mortality. Rev. Saude Publica 48:881-888; doi:10.1590/S0034-8910.2014048005218.

Prieto CMJ, Mancilla FP, Astudillo OP, Reyes PA, Román AO. 2007. Excess respiratory diseases in children and elderly people in a community of Santiago with high particulate air pollution. Rev. Med. Chil. 135: 221-228.

Reyna MA, Nava ML, Reyna ME. 2013. Public health benefits by reduction of PM10 in Mexicali, Baja California, Mexico . 8th Pan Am. Heal. Care Exch. Conf. PAHCE 2013; doi:10.1109/PAHCE.2013.6568215.

Ribeiro H, Cardoso MRA. 2003. Air pollution and children's health in Sao Paulo (1986-1998). Soc. Sci. Med. 57:2013-2022; doi:10.1016/S0277-9536(03)00068-6.

Riguera D, Andre PA, Trevisan Zanetta DM. 2011. Sugar cane burning pollution and respiratory symptoms in schoolchildren in Monte Aprazivel, Southeastern Brazil. Rev. Saude Publica 45: 878886.

Romero-Lankao P, Borbor-Cordova M, Abrutsky R, Guenther G, Behrentz E, Dawidowsky L. 2013. ADAPTE: A tale of diverse teams coming together to do issue-driven interdisciplinary research. Environ. Sci. Policy 26:29-39; doi:10.1016/j.envsci.2011.12.003.

Romero-Placeres M, Más-Bermejo P, Lacasaña-Navarro M, Téllez Rojo-Solís MM, Aguilar-Valdés J, Romieu I. 2004. Air pollution, bronchial asthma, and acute respirator and infections in children less years of age, Habana City . Salud Publica Mex. 46: 222-233.

Romieu I, Gouveia N, Cifuentes LA, de Leon AP, Junger W, Vera J, et al. 2012. Multicity study of air pollution and mortality in Latin America (the ESCALA study). Res. Rep. Health. Eff. Inst. 5-86.

Romieu I, Ramírez-Aguilar M, Moreno-Macias H, Barraza-Villarreal A, Miller P, Hernández-Cadena L, et al. 2004. Infant mortality and air pollution: Modifying effect by social class. J. Occup. Environ. Med. 46:1210-1216; doi:10.1097/01.jom.0000147224.35351.08.

Rosa AM, Ignotti E, Hacon S de S, Castro HA de. 2008. Analysis of hospitalizations for respiratory diseases in Tangara da Serra, Brazil. J. Bras. Pneumol. publicacao Of. da Soc. Bras. Pneumol. e 
Tisilogia 34: 575-582.

Saldiva PHN, Lichtenfels AJFC, Paiva PSO, Barone IA, Martins MA, Massad E, et al. 1994. Association between air pollution and mortality due to respiratory diseases in children in Sao Paulo, Brazil: A preliminary report. Environ. Res. 65:218-225; doi:10.1006/enrs.1994.1033.

Saldiva PHN, Pope III CA, Schwartz J, Dockery DW, Lichtenfels AJ, Salge JM, et al. 1995. Air pollution and mortality in elderly people: A time-series study in Sao Paulo, Brazil. Arch. Environ. Health 50: $159-163$

Salinas M, Vega J. 1995. The effect of outdoor air pollution on mortality risk: An ecological study from Santiago, Chile. World Heal. Stat. Q. 48: 118-125.

Sanhueza P, Torreblanca M, Diaz-Robles L, Schiappacasse L, Silva M, Astete T. 2009. Particulate air pollution and health effects for cardiovascular and respiratory causes in Temuco, Chile: a woodsmoke-polluted urban area. J. Air Waste Manag. Assoc. 59: 1481-1488.

Sanhueza P, Vargas C, Mellado P, Sanhueza H P, Vargas R C, Mellado G P. 2006. Impact of air pollution by fine particulate matter (PM10) on daily mortality in Temuco, Chile. Rev. Med. Chil. 134:754761; doi:/S0034-98872006000600012.

Sanhueza PA, Diaz-Robles LA, Torreblanca MA, Shiappacasse LN, Silva MP, Astete TD. 2008. Particulate air pollution and health effects for cardiovascular and respiratory causes in Temuco City, Chile. Proc. Air Waste Manag. Assoc. Annu. Conf. Exhib. AWMA 1: 184-188.

Santos UP, Terra-Filho M, Lin CA, Pereira LAA, Vieira TCB, Saldiva PHN, et al. 2008. Cardiac arrhythmia emergency room visits and environmental air pollution in Sao Paulo, Brazil. J. Epidemiol. Community Health 62:267-272; doi:10.1136/jech.2006.058123.

Sharovsky R, César LAM, Ramires JAF. 2004. Temperature, air pollution, and mortality from myocardial infarction in São Paulo, Brazil. Brazilian J. Med. Biol. Res. 37: 1651-1657.

Silva AMC da, Mattos IE, Freitas SR, Longo KM, Hacon SS. 2010. Material particulado (PM2.5) de queima de biomassa e doenças respiratórias no sul da Amazônia brasileira diseases in the south of the Brazilian Amazon. Rev. Bras. Epidemiol. 13: 337-351.

Silva CBP da, Nascimento Saldiva PH, Amato-Lourenco LF, Rodrigues-Silva F, El Khouri Miraglia SG, Silva CBPD, et al. 2012. Evaluation of the air quality benefits of the subway system in São Paulo, Brazil. J. Environ. Manage. 101:191-196; doi:10.1016/j.jenvman.2012.02.009.

Silva DR, Viana VP, Müller AM, Livi FP, Dalcin PDTR. 2014. Respiratory viral infections and effects of meteorological parameters and air pollution in adults with respiratory symptoms admitted to the emergency room. Influenza Other Respi. Viruses 8:42-52; doi:10.1111/irv.12158.

Silva EN, Ribeiro H. 2012. Impact of urban atmosphericenvironment on hospital admissions in the elderly. Rev. Saude Publica 46:694-701; doi:10.1590/S0034-89102012005000052.

Sousa SI V, Pires JCM, Martins EM, Fortes JDN, Alvim-Ferraz MCM, Martins FG. 2012a. Short-term effects of air pollution on respiratory morbidity at Rio de Janeiro--PART I: Air pollution assessment. Environ. Int. 44:18-25; doi:10.1016/j.envint.2012.01.005.

Sousa S, Pires J, Martins E, Fortes J, Alvim-Ferraz M, Martins F. 2012b. Short-term effects of air pollution on respiratory morbidity at Rio de Janeiro-Part II: health assessment. Env. Int. 43:1-5; doi:10.1016/B978-84-458-2066-7.00003-3.

Souza J, Reisen V, Santos J, Franco G. 2014. Principal components and generalized linear modeling in the correlation between hospital admissions and air pollution. Rev. Saude Publica 48:451-458; doi:10.1590/S0034-8910.2014048005078.

Steven GA, Dias RH, Ezzati M, Stevens GA, Dias RH, Ezzati M. 2008. The effects of 3 environmental risks on mortality disparities across Mexican communities. Proc. Natl. Acad. Sci. U. S. A. 105:16860-16865; doi:10.1073/pnas.0808927105.

Target A, Cabanes P-A. 2005. Air pollution and emergency room visits due to chronic lower respiratory diseases in the elderly: An ecological time-series study in São Paulo, Brazil . Pollut. Atmos. 9-10.

Telez-Rojo MM, Romieu I, Ruiz-Velasco S, Lezana M-AA, Hernandez-Avila MM, Téllez-Rojo MM, et al. 2001. Daily respiratory mortality and PM10 pollution in Mexico City [1]. Eur. Respir. J. 18:1076; doi:10.1183/09031936.01.00252101.

Tellez-Rojo MM, Romieu I, Polo-Pena M, Ruiz-Velasco S, Meneses-Gonzalez F, Hernandez-Avila M. 1997. Effect of environmental pollution on medical visits for respiratory infection in children from Mexico City. Salud Publica Mex. 39:513-522; doi:10.1590/S0036-36341997000600004.

Tellez-Rojo MM, Romieu I, Ruiz-Velasco S, Lezana M-A, Hernandez-Avila M-M. 2000. Daily respiratory mortality and PM10 pollution in Mexico City: Importance of considering place of death. Eur. Respir. J. 16:391-396; doi:10.1034/j.1399-3003.2000.016003391.x.

Tellez-Rojo MM, Romieu I, Ruiz-Velasco S, Meneses F, Lezana MA, Hernandez-Avila M. 1999. Daily respiratory mortality and air pollution in Mexico City: Importance of considering place of death. 
Epidemiology 10: S45-S45.

Vera J, Cifuentes L. 2009. Socioeconomic Status Modifies the Association Betwen Hospitalizations and Air Pollution (PM10, PM2.5 and O-3) in Santiago, Chile. Epidemiology 20: S90-S90.

Vera J, Cifuentes LA, Strappa V. 2007. Association of particulate matter and hospital admissions in Santiago, Chile. Epidemiology 18: S210-S211.

Yanagi Y, de Assunção J V, Barrozo L V. 2012. The impact of atmospheric particulate matter on cancer incidence and mortality in the city of São Paulo, Brazil . Cad. Saude Publica 28:1737-1748; doi:10.1590/S0102-311X2012000900012.

Zamorano A, Marquez S, Aranguiz JL, Bedregal P, Sanchez I, Zamorano W A, et al. 2003. Association of acute bronchiolitis with environmental variables. Rev. Med. Chil. 131: 1117-1122. 
Anexo C.

Manuscrito preparado para o Livro Branco da Água. Ainda não publicado.

\section{Crise hídrica em São Paulo e saúde}

Laís Fajersztajn e Paulo Saldiva

A rápida expansão da mancha urbana na região metropolitana de São Paulo resultou em alterações do microclima da região, agravadas pelas mudanças climáticas. Antes conhecida como terra da garoa, a região convive atualmente com períodos alternados de seca e chuvas intensas que impactam significativamente a saúde de seus moradores e impõe novos desafios para a proteção da saúde pública. Embora por motivos divergentes, doenças de veiculação hídrica reemergem em taxas elevadas durante a cheia e a seca, ameaçando conquistas importantes da saúde pública, como a queda da mortalidade infantil por diarreia. Ainda, determinados contaminantes presentes na água para consumo humano ameaçam a saúde para além das conhecidas diarreias e outras doenças infecciosas, e estão cada vez mais relacionados ao câncer e outras doenças crônicas. Proteger a população das doenças de veiculação hídrica impostas pelo ambiente urbano atual é um desafio interdisciplinar que requer esforços que vão além das competências tradicionalmente atribuídas ao setor de saúde. Por exemplo, no Brasil, o Ministério do Meio Ambiente regulamenta a qualidade do ar, águas e solo e o Ministério da Saúde regulamenta a qualidade da água para consumo humano (Umbuzeiro, 2015). Como discutiremos adiante, a qualidade da água dos reservatórios influencia significativamente a qualidade da água que chega às torneiras, de modo que o diálogo entre as pastas é fundamental para um melhor desempenho da saúde coletiva. O mesmo vale para outras disciplinas do conhecimento e escalas de governo. O desafio atual de promoção da saúde pública passa necessariamente pelo desafio da gestão integrada e efetiva de conhecimentos.

No caso dos recursos hídricos, o arcabouço legal já aponta na direção da gestão integrada, mas a prática ainda apresenta muitos desafios. Em conformidade com discussões internacionais, a gestão integrada e descentralizada dos recursos hídricos já é reconhecida por lei no Brasil. Apesar do pioneirismo do estado de São Paulo em promulgar uma política integrada e descentralizada dos Recursos Hídricos em 
$1991^{*}$ (a política nacional em moldes similares é de 1997) ${ }^{\dagger}$, a efetividade prática deste prática deste modelo tem sido criticada, particularmente durante a crise hídrica do estado iniciada em 2012 e intensificada no verão de 2013/2014. Em artigo recente publicado na revista "Estudos Avançados", Jacobi e colaboradores (2015) apontaram falhas do governo do Estado de São Paulo em integrar a sociedade na discussão das soluções para o enfrentamento da crise hídrica na região, reforçadas por falhas na cobertura da mídia. $\mathrm{O}$ artigo pode servir como referência para entender parte do arcabouço legal (incluindo descrição das Bacias Hidrográficas da região) e práticas administrativas da gestão dos recursos hídricos no Estado de São Paulo.

Valentim (2015) deixa clara a preocupação do setor de saúde com a evolução contínua do conceito de potabilidade frente aos novos conhecimentos científicos e às modificações dinâmicas do cenário onde se dá a produção da água (bacia hidrográfica). Ele destaca os Planos de Segurança da Água-artigo 13 da Portaria Federal vigente (MS 2914/2011)- como o grande avanço legal, pois vão além da potabilidade e das características físicas e operacionais do sistema ou solução alternativa, e incluem controle e vigilância da qualidade da água desde o manancial até o consumidor. No entanto, ao fazer recomendações para o estabelecimento efetivo dos Planos de Segurança da Água, Valentim (2015) acaba por revelar que, apesar dos esforços, na prática a gestão dos recursos hídricos ainda não está de fato integrada. Embora ressalte a importância da discussão para avanços futuros, Valentim (2015) relata o insucesso de uma discussão ocorrida em 2008 entre diversas secretarias estaduais (Saúde, Meio Ambiente, Recursos Hídricos e Saneamento e Agricultura e Abastecimento) em estabelecer dispositivos legais regulamentadores para uma gestão pública integrada de segurança da água de consumo humano em São Paulo.

A crise hídrica vivenciada em São Paulo a partir, principalmente, do verão 2013/2014, parece evidenciar uma crise de integração de conhecimentos traduzida numa dificuldade real de gestão integrada dos recursos hídricos, exemplificada tanto por Valentim (2015), quanto por Jacobi e colaboradores (2015). A proteção da saúde pública frente às exposições impostas pela crise hídrica de São Paulo vai depender da difícil tarefa de integrar conhecimentos diversos, produzidos a partir de gramáticas diversas. Nossa proposta é uma leitura do cenário hídrico de São Paulo numa

\footnotetext{
* Política Estadual de Recursos Hídricos, Lei n.7.663, promulgada em 1991

† Política Nacional de Recursos Hídricos, Lei n.9.433, promulgada em 1997
} 
perspectiva de saúde. É possível, e na verdade desejável, que outros textos sejam mais eficientes em explicar pormenores das interações ambientais, legislação a cerca da gestão dos recursos hídricos e respostas técnicas. O nosso objetivo é dar uma perspectiva ampliada dos aspectos da gestão hídrica relacionados à saúde, para além dos já reconhecidos padrões de potabilidade. Primeiro, discutiremos os desafios da qualidade da água para consumo humano impostos pelo período de seca. Abordaremos os possíveis impactos para a saúde originados pela deficiência nos sistemas de distribuição de água e pelo aumento da poluição dos reservatórios. A estiagem diminui a capacidade de diluição dos poluentes dos reservatórios, aumentando a poluição dos mesmos. As possíveis consequências exploradas neste artigo são o aumento dos contaminantes químicos na água pelo maior uso de produtos para tratamento da água e a proliferação de cianobactérias com resíduos tóxicos nos reservatórios de água. Também discutiremos consequências para a saúde do possível aumento de uso de fontes de água mais poluídas e de fontes não controladas. A figura 1 exemplifica as possíveis relações entre estiagem e saúde. Em seguida, discutiremos aspectos das mudanças no microclima regional, com ênfase nas ilhas urbanas de calor. A primeira vista pouco relacionada com a estiagem, à alteração no microclima regional auxilia no entendimento mais amplo da crise hídrica, para além da situação atual, porque traz a perspectiva de como o estilo de vida urbano impacta na saúde do meio ambiente, que nos fornece a água, e na saúde humana. Por fim, para enfrentar o cenário atual, sugerimos que esforços integrados de saberes, como os propostos nesta publicação, sejam orientados sob o objetivo comum de proteger a saúde coletiva.

\section{Qualidade da água para consumo humano}

O principal impacto para a saúde humana da estiagem na cidade de São Paulo é seu potencial comprometimento da qualidade da água. Superadas através de medidas sanitárias bem sucedidas, as doenças infecciosas de veiculação hídrica tendem a reemergir com algumas especificidades características do contexto atual, incluindo a possível emergência de doenças crônicas. Dentre as doenças infecciosas de veiculação hídrica, vale destacar a diarreia. Responsável por desconforto e limitação momentânea, a consequente desidratação causada pela diarreia pode ter impactos devastadores em grupos vulneráveis como crianças e idosos. Em 2013, 57,8 mil crianças menores de cinco anos morreram no mundo como consequência da diarreia, em geral originadas por 
problemas de qualidade da água (Liu et al., 2015). Em países em desenvolvimento, a ocorrência de episódios frequentes de diarreia na infância tem sido cada vez mais relacionada com prejuízos no crescimento e desenvolvimento cognitivo das crianças. $\mathrm{O}$ prejuízo em longo prazo iria além da saúde pública nacional, prejudicando o desempenho da economia, por perda de capital humano. O mecanismo por trás dessa associação seria a relação entre a infecção gastrointestinal e a desnutrição, condição reconhecidamente associada ao prejuízo do desenvolvimento infantil. A inflamação decorrente da diarreia prejudicaria a absorção de nutrientes. Haveria também perda de proteínas. Ambos resultando em má nutrição. A desnutrição por sua vez, prejudicaria a resposta inerente do sistema digestivo, exacerbando a gravidade da infecção e impulsionando um ciclo vicioso (Maclntyre et al., 2014).

\subsection{Deficiências no sistema de distribuição}

O período de estiagem em São Paulo veio acompanhado de relatos de intermitência e baixa pressão nos sistemas de distribuição de água. Ambas as condições estão entre as deficiências de distribuição de água reconhecidamente associadas a surtos de doenças de veiculação hídrica (Lee \& Schwab 2005), em particular diarreia. A interrupção da distribuição de água em redes de distribuição contínua favorece a contaminação externa da água do sistema, desde que haja deficiências na integridade do encanamento, o que pode resultar em aumento da incidência de infecção do trato intestinal. Embora haja heterogeneidade significativa entre os estudos, uma metánalise recente (Ercumen et al., 2014), mostrou que o risco de aumento combinado (quatro estudos) na incidência de infecção do trato intestinal durante períodos de interrupção na distribuição de água pode ser 3,26 vezes maior comparado com períodos de operação normal do mesmo sistema.

Relatos de jornal, baseados em dados do Centro de Vigilância Epidemiológica do Estado de São Paulo, mostram que em 2014, ano de estiagem, o estado registrou 315 mil casos de diarreia. O pico ocorreu em fevereiro, quando foram observados $70 \%$ mais casos de diarreia que a média esperada (35 mil contra 20 mil casos). Além das interrupções no abastecimento e da baixa pressão no sistema, os jornais também apontam a origem da água (uso do volume morto das represas e de água de poços e caminhões pipa) como possíveis causas da epidemia de diarreia no estado (Felix 2015; Martín 2015). De fato, a contaminação na fonte também configura uma deficiência no sistema de abastecimento de água relacionada a surtos de diarreia (Ercumen et al., 2014). 


\subsection{Aumento da poluição dos reservatórios}

Durante períodos de estiagem, a qualidade da água dos reservatórios fica prejudicada, pois há menos água para diluir os poluentes presentes nas fontes remanescentes. Além disso, passa-se a considerar o uso de fontes com qualidade inferior, que não estavam sendo utilizadas anteriormente. Ambas as situações exigem o uso de processos químicos mais agressivos para garantir a potabilidade da água, aumentando a formação de um grupo de contaminantes orgânicos conhecidos pela terminologia em inglês "desinfection by-products", os DBPs. Mais de 700 componentes químicos já foram identificados como DBPs (Villanueva et al., 2014). Os DBPs são gerados a partir da reação química entre matéria orgânica e desinfetante usada para reduzir os microrganismos patogênicos da água, como cloro e ozônio. Presentes na água para consumo humano e também em piscinas de uso recreativo, os DBPs têm sido consistentemente associados com alterações no desenvolvimento e na reprodução humana, além de estarem relacionados com o surgimento de câncer, particularmente câncer de bexiga (Richardson \& Ternes, 2014).

Se por um lado o tratamento adequado da água para consumo humano diminuiu significativamente as doenças infecciosas por contaminação microbiológica, o aumento da poluição dos reservatórios de água impõe um novo risco de saúde para a população por aumentarem a poluição da água de consumo humano por DBPs. Em recente revisão, Villanueva \& colaboradores (2014) listaram recomendações para estudos epidemiológicos futuros sobre químicos presentes na água, tópico ainda pouco estudado, em parte por dificuldades metodológicas. Os autores destacam a necessidade de estudar os químicos emergentes, substâncias para as quais não há regulamentação sobre concentrações de segurança, mesmo em países desenvolvidos.

Por fim, a estiagem aumenta o uso de fontes alternativas de água, como poços e carro pipa, para as quais o controle de qualidade da água é menos frequente ou inexistente. O uso de fontes de água não tratada aumenta o risco de doenças de veiculação hídrica - em especial infecções entéricas, para as quais já há métodos conhecidos e efetivos de prevenção.

A atividade humana (esgoto, detergente e outros) tem resultado no acúmulo excessivo de nutrientes nos corpos de água doce (eutrofização), aumentando a ocorrência e a intensidade de cianobactérias nos reservatórios de água (Pantelic et al., 2013), alterando gosto e coloração da água. O excesso de nutrientes (principalmente 
nitrogênio e fósforo), calor (acima de $20^{\circ} \mathrm{C}$ ), luz solar e água parada criam condições favoráveis para a proliferação de cianobactérias (Cheung, et al, 2013). O fenômeno altera o ecossistema aquático com prejuízos significativos para a saúde humana e para a economia. A diminuição do oxigênio na água, em última análise, resulta na morte de peixes e a redução da atividade turística nas regiões afetadas impacta a economia. $\mathrm{O}$ custo anual da eutrofização dos corpos de água doce nos Estados Unidos pode superar \$2.2 bilhões de dólares (Cheung et al., 2013). Não encontramos evidências para o custo no Brasil.

Dentre os variados metabólitos produzidos pelas cianobactérias, muitos são hepatotóxicos, neurotóxicos ou dermatotóxicos (Cheung et al., 2013) e alguns, como a microcistina, são carcinogênicos (IARC 2010) e possuem padrões de qualidade estabelecidos pela Organização Mundial da Saúde. Outras toxinas produzidas por cianobactérias têm graves efeitos de longo prazo, das quais estão a anatoxina (arritmia cardíaca), lyngybia (câncer de pele), cilindrospermopsina (falencia hepática), entre outras (Cheung et al., 2013). A alta concentração de nutrientes na água e o aquecimento global podem favorecer a predominância de toxinas tóxicas sobre não tóxicas (Merel, et al., 2013). A exposição ocorre durante o uso recreativo da água contaminada e pela ingestão direta da mesma.

Em 1988, após um episódio de enchente na Bahia, um surto de infecção gastrointestinal matou 88 pessoas e deixou 2.000 doentes, devido à contaminação por cianobactéria da água para consumo humano da região (Teixeira et al., 1993). Em 1996, 52 dentre 116 pacientes de uma clínica de hemodiálise em Caruaru, Pernambuco, morreram devido a presença de microistina na água utilizada na diálise e $89 \%$ dos pacientes apresentaram algum sintoma adverso como vômito, náusea, tontura e fraqueza muscular (Azevedo et al., 2002). Além de contaminar diretamente a água através da liberação de toxinas, o aumento das cianobactérias também pode resultar em exposição aumentada aos DBPs (Cheung et al., 2013).

Atualmente, os processos convencionais de tratamento da água, se conduzidos de forma adequada, são efetivos na remoção de toxinas (Cheung et al., 2013). Vale ressaltar que, além de reduzir a incidência de diarreia e outras infecções entéricas, a melhoria na qualidade da água dos reservatórios através do tratamento do esgoto diminuiria os problemas decorrentes do excesso de produtos para tratamento. Uma revisão sistemática concluiu que sistemas de tratamento de esgoto podem reduzir o risco 
de diarreia em 30\% (Norman et al., 2010), chamando a atenção para a questão da ocupação em áreas de mananciais, origem de parte do esgoto não tratado depositado nas represas. Por diminuir a diluição dos poluentes, a estiagem agrava ainda mais a poluição decorrente do não tratamento do esgoto. A implementação efetiva dos Planos de Segurança da água previstos na portaria federal (MS 2914/2011), (Valentim 2015) seria de grande auxílio no controle sistemático da poluição dos reservatórios.

Figura 1. Possíveis relações entre estiagem, poluição de reservatórios e saúde.

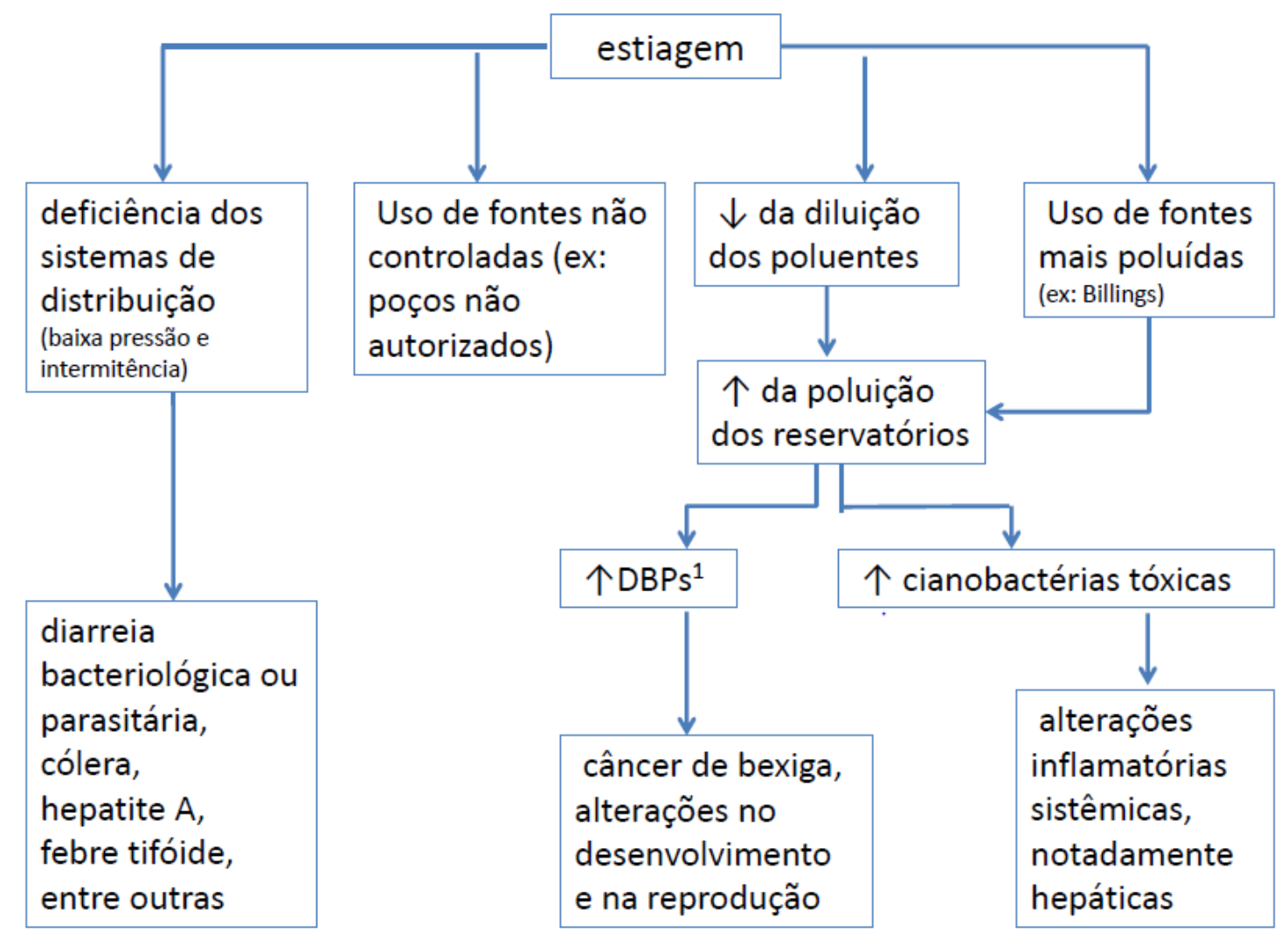

${ }^{1}$ poluição por uso de produtos químicos

\section{Alterações do microclima regional}

As mudanças do microclima da cidade resultam em inundação de um lado e falta de água do outro, ambos com impactos significativos para a saúde.

Em São Paulo, a diferença de temperatura entre o centro da cidade e a periferia pode atingir até $10^{\circ} \mathrm{C}$. Consequência do processo de urbanização, o fenômeno conhecido como ilha urbana de calor tem origem na substituição da cobertura vegetal do solo por prédios, ruas, avenidas e outras construções de infraestrutura urbana. Tal cobertura do solo absorve mais luz solar, irradia calor e retém menos água, reduzindo a umidade para 
evaporação e resfriamento, comparado com a cobertura natural (Sobral, 2005). O desmatamento e a ocupação em áreas de mananciais contribuem para as alterações do microclima paulista. A queima intensiva de combustíveis fósseis por veículos automotores e os altos prédios da cidade que atuam como barreiras para a ventilação, também explicam parte do fenômeno (Sobral, 2005). Como resultado, durante o verão, a diferença de temperatura entre a zona central (quente) e a periférica (menos quente) da cidade aumenta eventos de chuva forte nas partes centrais da cidade (Silva Dias et al., 2013), muitas vezes, sem ocorrência de chuvas nas áreas periféricas, justamente onde se localizam os reservatórios para abastecimento de água das cidades.

Embora desconheçamos estimativas quantitativas da contribuição das ilhas de calor para a estiagem do verão 2013/2014, as alterações climáticas promovidas pelas ilhas de calor têm contribuído para a diminuição da água nos reservatórios ao longo dos últimos anos.

As chuvas fortes favorecem enchentes com efeitos adversos para a saúde humana. Dentre os mais conhecidos e imediatos estão os traumas ortopédicos, afogamentos e doenças de veiculação hídrica como diarreias agudas, febre tifoide, cólera e hepatite A (Du et al., 2010). A água parada da enchente também favorece a reprodução do mosquito aedes aegypti, transmissor da dengue febre e chikunguya e zika vírus. Este último, além de febre, náusea, mialgia e manchas pelo corpo, pode prejudicar o desenvolvimento neurológico dos fetos e recentemente tem sido associado com o aumento significativo da incidência de microcefalia em neonatos no Brasil, mortalidade fetal e síndrome de Guillain-Barré. Segundo dados do site do Centro de Vigilância Epidemiológica do Estado de São Paulo, o número total de casos de dengue no estado de São Paulo saltou de 7.554 em 2013 para 204.236 em 2014, ano de estiagem. Considerando que o verão mais seco reduz o risco de ocorrências de enchentes, o armazenamento residencial de água da chuva para enfrentar o desabastecimento emerge como possível fator colaborador para o surto de dengue. Dependendo da intensidade da chuva e características do local do evento, as inundações podem espalhar diversos químicos industriais e da agricultura, contribuindo para a contaminação da água e floração de bactérias, cujos prejuízos para a saúde já foram discutidos neste artigo.

As ilhas urbanas de calor dificultam a dispersão de poluentes, com prejuízos significativos para a saúde da população no curto e no médio prazo. Além do desconforto geral (ardor nos olhos, alergias, etc.), a exposição de curto período a altos 
níveis de poluentes atmosféricos aumenta a incidência de internação hospitalar por doenças cardiovasculares e respiratórias (Braga et al., 2002; Gouveia et al., 2006). A exposição prolongada à poluição do ar aumenta o risco de câncer de pulmão e de morte por causas cardiovasculares e respiratórias (Pope et al., 2002; Fajersztajn et al., 2013). A exposição à poluição do ar ainda está associada com hipertensão gestacional, baixo peso ao nascer e prematuridade (Stieb et al., 2012). O sistema endócrino (Andersen et al., 2012), neurológico (Calderón-Garcidueñas, et al., 2008), entre outros, também são negativamente afetados pela poluição do ar. As ilhas urbanas de calor favorecem a formação de um poluente secundário, o ozônio troposférico, fortemente relacionado a crises agudas de asma (Andrade et al., 2004), alterações cardiovasculares e inflamação sistêmica, além de aumento da mortalidade (Bell et al., 2014).

Ademais, as ilhas urbanas de calor aumentam os períodos prolongados de temperatura muito elevada, conhecidos como ondas de calor e associados com aumento da mortalidade, especialmente por causas respiratórias (Son et al., 2015). No Brasil, o calor extremo foi responsável por um aumento de 7,29\% (variação de 7,02 a 7,49\%) nas mortes entre 1997 e 2011. A média dos 13 países incluídos no estudo foi de $0,42 \%(0,39$ a 0,44\%) (Gasparrini et al., 2015). O aumento da temperatura também impacta a distribuição de vetores causadores de doenças como a dengue (Coelho-Zanotti \& Massad, 2012).

\section{Considerações finais}

A efetividade da gestão da crise hídrica poderá ser alcançada através de um esforço interdisciplinar entre conhecimentos e esferas de governo. A saúde pública pode ser um guia norteador dessas políticas.

Do ponto de vista científico, estudos sobre os impactos da crise da água para a saúde, ajustados para a realidade paulista, ainda são escassos. O momento é uma oportunidade para planejar estudos de longa duração que embasem políticas públicas de gestão da água. Tais estudos podem prever os impactos adversos para a saúde das medidas de gestão da água antes da ocorrência dos mesmos, gerando oportunidades de prevenção. Tais estudos precisam garantir as conquistas da diminuição dos surtos de doenças infecciosas como a diarreia. Ainda, evidências científicas locais robustas sobre os impactos para a saúde individual e coletiva dos químicos emergentes presentes na água podem facilitar a regulamentação desses químicos, medida fundamental para a 
proteção da saúde coletiva.

A mídia poderia informar a sociedade de maneira mais efetiva a cerca da dimensão da crise hídrica, combatendo o senso comum de que São Paulo está inserido em uma área de disponibilidade hídrica em quantidade e qualidade suficiente. A segurança hídrica na Região Metropolitana de São Paulo está na pauta dos principais meios de comunicação desde o início de 2014, mas é preciso ir além. É preciso enfatizar outros fatores importantes no entendimento integrado da crise hídrica, que não somente a falta de chuvas. O desmatamento e ocupação em áreas de mananciais, falta de investimentos para a redução de perdas e a má qualidade das águas dos rios por falta de tratamento de esgoto doméstico são exemplos.

\section{Referências}

Andersen, Z.J., Raaschou-Nielsen, O., Ketzel, M., at al. (2012). Diabetes incidence and long-term exposure to air pollution: a cohort study. Diabetes Care. 35(1):92-98.

Andrade, M. F., Ynoue, R. Y., Harley, R., Miguel, A. H. (2004). Air-quality model simulating photochemical formation of pollutants: the São Paulo Metropolitan Area, Brazil. International Journal Environment and Pollution. 22 (4), 460-475.

Azevedo, S.M.F.O., Carmichael, W.W., Jochimsen, E.M., et al. (2002).Human intoxication by microcystins during renal dialysis treatment in Caruaru*/Brazil. Toxicology. 181:441-446.

Bell, M.L., Zanobetti, A., Dominici, F. Who is more affected by ozone pollution? A systematic review and meta-analysis. (2014). Am J Epidemiol. 180(1),15-28.

Braga, A.L.F., Zanobetti, A., Schwartz, J. (2002). The effect of weather on respiratory and cardiovascular deaths in 12 U.S. cities. Environmental Health Perspectives. 110(9),859-863.

Calderón-Garcidueñas, L., Solt, A. C., Henríquez-Roldán, C., Torres-Jardón, R., Nuse, B., Herritt, L., Villarreal-Calderón, R., Osnaya, N., Stone, I., García, R., Brooks, D. M., González-Maciel, A., ReynosoRobles, R., Delgado-Chávez, R., \& Reed, W. (2008). Long-term air pollution exposure is associated with neuroinflammation, an altered innate immune response, disruption of the blood-brain barrier, ultrafine particulate deposition, and accumulation of amyloid beta-42 and alpha-synuclein in children and young adults. Toxicologic Pathology, 36(2), 289-310. http://dx.doi.org/10.1177/0192623307313011

Cheung, M.Y. Liang, S., Lee, J. (2013). Toxin-producing Cyanobacteria in Freshwater: A Review of the Problems, Impact on Drinking Water Safety, and Efforts for Protecting Public Health. Journal of Microbiology. 51(1): 1-10.

Coelho-Zanotti, M. S. S., \& Massad, E. (2012). The impact of climate on Leptospirosis in São Paulo, Brazil. International Journal of Biometeorology. 56 (2),233-241.

Ercumen A, Gruber JS, Colford JM Jr. 2014. Water distribution system deficiencies and gastrointestinal illness: a systematic review and meta-analysis. Environ Health Perspect. 122:651-660.

Fajersztajn, L., Veras, M., Barrozo, L. V., \& Saldiva, P. (2013). Air pollution: a potentially modifiable risk factor for lung cancer. Nat Rev Cancer. 13(9):674-678.

Felix, P. SP teve hiperepidemia de diarreia no primeiro ano da crise hídrica. Estado de São Paulo. 28.07.2015. Disponível em: http://saude.estadao.com.br/noticias/geral,sao-paulo-teve-hiperepidemia-dediarreia-no-ano-em-que-crise-hidrica-comecou, 1733925

Gasparrini, A., Guo, Y., Hashizume, M., Lavigne, E., et al. (2015). Mortality risk attributable to high and low ambient temperature: a multicountry observational study. Lancet. [Epub ahead of print]

IARC. World Health Organization International Agency For Research On Cancer. (2010). Monographs on the Evaluation of Carcinogenic Risks to Humans: Ingested Nitrate and Nitrite, and Cyanobacterial 
$\begin{array}{lllll}\text { Peptide } & \text { Toxins. } & \text { VOLUME } & \text { Disponível } & \text { em: }\end{array}$

http://monographs.iarc.fr/ENG/Monographs/vol94/mono94.pdf

Jacobi, P.R., Cibim, J. Leão, R.S. (2015). Crise hídrica na Macrometrópole Paulista e respostas da sociedade civil. Estudos Avançados. 29 (84):27-42.

Lee, E.J.; Schwab, K.J. (2005). Deficiencies in drinking water distribution systems in developing countries. J Water Health. 3:109-127.

Liu, L., Oza, S., Hogan, D., Perin, J., Rudan, I., Lawn, J.E., Cousens, S., Mathers, C., Black, R.E. (2015). Global, regional, and national causes of child mortality in 2000-13, with projections to inform post-2015 priorities: an updated systematic analysis. Lancet. 385: 430-40.

MacIntyre, J., McTaggart, J., Guerrant, R.L., Goldfarb, D.M. (2014). Early childhood diarrhoeal diseases and cognition: are we missing the rest of the iceberg? Paediatrics and International Child Health. 34(4):295-307.

Martin, M. Durante a crise hídrica, casos de diarreia se multiplicam em São Paulo. El Pais.16.07.2015. Disponível em: http://brasil.elpais.com/brasil/2015/07/10/politica/1436557827 946009.html

Merel, S., Walker, D., Chicana, R., Snyder, S., Baurès, E., Thomas, O. (2013). State of knowledge and concerns on cyanobacterial blooms and cyanotoxins. Environment International. 59:303-327.

Norman, G., Pedley, S., Takkouche, B. (2010). Effects of sewerage on diarrhoea and enteric infections: a systematic review and meta-analysis. Lancet Infect Dis. 10: 536-544.

Pantelic, D., Svirc, Z., Simeunovic, J., Vidovic, M., Trajkovic, I. (2013). Cyanotoxins: Characteristics, production and degradation routes in drinking water treatment with reference to the situation in Serbia. Chemosphere. 91(4):421-441.

Pope, C. A. , Burnett, R.T., Thun, M.J., Calle, E.E., Krewski D, Ito, K., Thurston, G.D. (2002). Lung cancer, cardiopulmonary mortality and long-term exposure to fine particulate air pollution. JAMA. 287:1132-41.

Richardson,S.D., Ternes, T.A. (2014). Water Analysis: Emerging Contaminants and Current Issues. Anal. Chem. 86:2813-2848.

Silva Dias, M.M.F., Dias, J., Carvalho, L.M.V., Freitas, E.D. (2013). Changes in extreme daily rainfall for São Paulo, Brazil. Climatic Change. 116 (3-4):705-722.

Stieb, D.M., Chen, L., Eshoul, M., Judek, S. (2012). Ambient air pollution, birth weight and preterm birth: a systematic review and meta-analysis. Environ Res. 117:100-11.

Sobral, R. H. (2005). Heat Island in São Paulo, Brazil. Critical Public Health. 15(2): 147- 156.

Son, J., Gouveia, N., Bravo, M.A., Freitas, C.U., Bell, M.L. (2015). The impact of temperature on mortality in a subtropical city: effects of cold, heat, and heat waves in São Paulo, Brazil. Int $\mathrm{J}$ Biometeorol . May [Epub ahead of print].

Teixera, M.G.L.C., Costa, M.C.N., Carvalho, V.L.P., Pereira, M.S., Hage, E. (1993). Gastroenteritis epidemic in the area of the Itaparica Dam, Bahia, Brazil. Bull. Pan. Am. Health Organ. 27:244-253.

Umbuzeiro, G.A. (2015). The need of scientific based regulations of chemicals in water: A proposal for Brazil. Applied Research in Toxicology. 1(1):48-49.

Villanueva, C.M., Kogevinas, M., Cordier, S., et al. (2014). Assessing exposure and health consequences of chemicals in drinking water: current state of knowledge and research needs, Environ Health Perspectives. 122:213-221.

Valentim, L.S.O. (2015). O plano de segurança da água no contexto sanitário paulista The water safety plan in São Paulo healthcare setting. BEPA. 12(141):35-40. 
Anexo D.

Registro do protocolo da overview ${ }^{*}$.Prospero, número de registro CRD 42016043498.

UNIVERSITY of $/$ ork

Centre for Reviews and Dissemination

National Institute for

Health Research

PROSPERO International prospective register of systematic reviews

Review title and timescale

1 Review title

Give the working title of the review. This must be in English. Ideally it should state succinctly the interventions or exposures being reviewed and the associated health or social problem being addressed in the review.

Epidemiological time series studies of short-term effects of air pollution: a protocol of an overview of systematic reviews.

2 Original language title

For reviews in languages other than English, this field should be used to enter the title in the language of the review. This will be displayed together with the English language title.

3 Anticipated or actual start date

Give the date when the systematic review commenced, or is expected to commence. 26/07/2016

4 Anticipated completion date

Give the date by which the review is expected to be completed. 30/12/2016

5 Stage of review at time of this submission

Indicate the stage of progress of the review by ticking the relevant boxes. Reviews that have progressed beyond the point of completing data extraction at the time of initial registration are not eligible for inclusion in PROSPERO. This field should be updated when any amendments are made to a published record.

The review has not yet started $\quad \sqrt{ }$

Review stage

Preliminary searches

Piloting of the study selection process

Formal screening of search results against eligibility criteria

Data extraction

Risk of bias (quality) assessment

Data analysis

$\begin{array}{cc}\text { Started } & \text { Completed } \\ \text { No } & \text { No } \\ \text { No } & \text { No } \\ \text { No } & \text { No } \\ \text { No } & \text { No } \\ \text { No } & \text { No } \\ \text { No } & \text { No }\end{array}$

Provide any other relevant information about the stage of the review here

Review team details

$6 \quad$ Named contact

The named contact acts as the guarantor for the accuracy of the information presented in the register record. Lais Fajersztajn

$7 \quad$ Named contact email

Enter the electronic mail address of the named contact

laisfajer@gmail.com

$8 \quad$ Named contact address

Enter the full postal address for the named contact.

Av. Doutor Arnaldo, 455

$9 \quad$ Named contact phone number

Enter the telephone number for the named contact, including international dialing code. 5511988233489

10 Organisational affiliation of the review

Full title of the organisational affiliations for this review, and website address if available. This field may be completed as 'None' if the review is not affiliated to any organisation.

"O termo em inglês "overview" é usado pelos teóricos em revisão sistemáticas e ainda não possui tradução para o português. Refere-se a revisões de revisões sistemáticas. 
UNIVERSITY of York

\section{Centre for Reviews and Dissemination}

Faculdade de Medicina, Universidade de São Paulo

Website address:

11 Review team members and their organisational affiliations

Give the title, first name and last name of all members of the team working directly on the review. Give the organisational affiliations of each member of the review team.

$\begin{array}{llll}\begin{array}{l}\text { Title } \\ \text { Miss }\end{array} & \begin{array}{l}\text { First name } \\ \text { Laís }\end{array} & \begin{array}{l}\text { Last name } \\ \text { Fajersztajn }\end{array} & \begin{array}{l}\text { Affiliation } \\ \text { Faculdade de Medicina, Universidade de São } \\ \text { Paulo }\end{array} \\ \text { Mr } & \text { Samuel } & \text { Osório } & \begin{array}{l}\text { Faculdade de Saúde Pública, Universidade } \\ \text { de São Paulo }\end{array} \\ \text { Dr } & \text { Luiz } & \text { Pereira } & \begin{array}{l}\text { Programa de Pós-graduação em Saúde } \\ \text { Coletiva, Universidade Católica de Santos }\end{array}\end{array}$

12 Funding sources/sponsors

Give details of the individuals, organizations, groups or other legal entities who take responsibility for initiating managing, sponsoring and/or financing the review. Any unique identification numbers assigned to the review by the individuals or bodies listed should be included. none

13 Conflicts of interest

List any conditions that could lead to actual or perceived undue influence on judgements concerning the main topic investigated in the review.

Are there any actual or potential conflicts of interest? None known

14 Collaborators

Give the name, affiliation and role of any individuals or organisations who are working on the review but who are not listed as review team members.
Title
First name
Last name
Organisation details

\section{Review methods}

15 Review question(s)

State the question(s) to be addressed / review objectives. Please complete a separate box for each question. Are systematic reviews based on epidemiological evidence from time series studies following major quality

recommendation for SRs? - What is the quality of them according to AMSTAR? - Which are the characteristics of the comprehensive search (language restrictions, databases and terms used)? - Which methodologies are being used to evaluate the quality of included studies? - Are they following specific guidelines for SR including SR in environmental epidemiology - Are they registering an a priori protocol? - Are they police recommending polices?

16 Searches

Give details of the sources to be searched, and any restrictions (e.g. language or publication period). The full search strategy is not required, but may be supplied as a link or attachment.

We will perform a comprehensive literature search of systematic reviews with and without meta-analysis at Pubmed, Embase, Scopus, Web of Science, Cochrane and Lilacs. No language or date restrictions will be imposed to the search.

17 URL to search strategy

If you have one, give the link to your search strategy here. Alternatively you can e-mail this to PROSPERO and we will store and link to it

I give permission for this file to be made publicly available Yes

18 Condition or domain being studied 
UNIVERSITY of Work

\section{Centre for Reviews and Dissemination}

National Institute for Health Research

Give a short description of the disease, condition or healthcare domain being studied. This could include health and wellbeing outcomes.

Daily health events (mortality and/or hospital admissions and/or emergency room visits and/or consultants) due to

short-term exposure (up to seven days) to air pollutants.

19 Participants/population

Give summary criteria for the participants or populations being studied by the review. The preferred format includes details of both inclusion and exclusion criteria.

All populations are eligible for this review

20 Intervention(s), exposure(s)

Give full and clear descriptions of the nature of the interventions or the exposures to be reviewed

Daily air pollution concentrations

21 Comparator(s)/control

Where relevant, give details of the alternatives against which the main subject/topic of the review will be compared

(e.g. another intervention or a non-exposed control group).

Not applicable

22 Types of study to be included

Give details of the study designs to be included in the review. If there are no restrictions on the types of study design eligible for inclusion, this should be stated.

Systematic reviews with or without meta-analyses of time-series studies evaluating the short-term health effects of air pollution.

23 Context

Give summary details of the setting and other relevant characteristics which help define the inclusion or exclusion criteria.

Recently, a growing body of systematic reviews (SR) on the short-term health effects of air pollution are been published, most of them based on evidenced from time-series studies. However, SRs focused on this research question seem not to follow important recommendations for high quality SRs. The previous registration of an a priori research protocol increases transparency and confidence, but apparently few SRs on the short-term health effects of air pollution are registered at specific databases of prospectively registered SRs. Similarly, few SRs on the topic have evaluated the internal validity of the included studies. Difficulties in extrapolating validated quality assessment tools to particularities of time-series studies (e.g. aggregated level data) might explain the scenario. Overviews (reviews of systematic reviews) are useful to evaluate methodological quality and other aspects of these reviews.

24 Primary outcome(s)

Give the most important outcomes.

Daily health events (mortality and/or hospital admissions and/or emergency room visits and/or consultants).

Give information on timing and effect measures, as appropriate

25 Secondary outcomes

List any additional outcomes that will be addressed. If there are no secondary outcomes enter None.

No restrictions for disease which caused the outcome.

Give information on timing and effect measures, as appropriate.

26 Data extraction (selection and coding)

Give the procedure for selecting studies for the review and extracting data, including the number of researchers involved and how discrepancies will be resolved. List the data to be extracted.

Two researchers will independently screen the studies by title and abstract for studies that meet the inclusion criteria. Disagreements will be solved through discussion, after we will retrieve all full reports screened. Two researchers will select studies independently for final inclusion and record the reasons for excluding studies. Disagreements will be solved through discussion. Researchers will not be blind for authors names, institutions or journal titles. For data collection, one reviewer will extract the data and a second reviewer will confirm the information. Disagreements will be solved by discussion. Data extraction will include: - bibliographic details (number and country of authors, journal, impact factor of the journal, search/publication date, language, funding source, number of citations of the review) search details (databases, period, number of included time-series studies) - major characteristics of the time-series 
UNIVERSITY of Work

\section{Centre for Reviews and Dissemination}

studies: pollutants, daily outcomes evaluated, population evaluated, subgroups evaluated (age, specific diseases, age group, social economic characteristics, etc.), settlement - Major time-series studies characteristics used to combine studies such as lag between exposure and health event. - methodologies used to appraise the quality of included studies - presence of meta-analysis and its summary effect - other characteristics necessary to evaluate if the SR followed specific guidelines (Mose, Prisma and Blair et al., 1995, Navigation Guide and/or National Institutes of Environmental Health Sciences National Toxicology Program). - other characteristics necessary to evaluate if the SR made police recomendations

27 Risk of bias (quality) assessment

State whether and how risk of bias will be assessed, how the quality of individual studies will be assessed, and whether and how this will influence the planned synthesis.

Two researchers will independently appraise the methodological quality of the systematic reviews using the

Measurement Tool to Assess Systematic Reviews (AMSTAR) tool. Disagreements will be solved through discussion

To the extent that Amstar work with scores, we will also evaluate the information extracted qualitatively.

28 Strategy for data synthesis

Give the planned general approach to be used, for example whether the data to be used will be aggregate or at the level of individual participants, and whether a quantitative or narrative (descriptive) synthesis is planned. Where

appropriate a brief outline of analytic approach should be given.

We will perform a descriptive synthesis of the data

29 Analysis of subgroups or subsets

Give any planned exploration of subgroups or subsets within the review. 'None planned' is a valid response if no

subgroup analyses are planned.

None planned.

Review general information

30 Type and method of review

Select the type of review and the review method from the drop down list.

Epidemiologic, Systematic review

Public health (including social determinants of health)

31 Language

Select the language(s) in which the review is being written and will be made available, from the drop down list. Use the control key to select more than one language.

English

Will a summary/abstract be made available in English?

Yes

32 Country

Select the country in which the review is being carried out from the drop down list. For multi-national collaborations select all the countries involved. Use the control key to select more than one country. Brazil

33 Other registration details

Give the name of any organisation where the systematic review title or protocol is registered together with any unique identification number assigned. If extracted data will be stored and made available through a repository such as the Systematic Review Data Repository (SRDR), details and a link should be included here.

34 Reference and/or URL for published protocol Give the citation for the published protocol, if there is one

Give the link to the published protocol, if there is one. This may be to an external site or to a protocol deposited with CRD in pdf format.

I give permission for this file to be made publicly available

Yes 
UNIVERSITY ofyork

\section{Centre for Reviews and Dissemination}

National Institute for Health Research

35 Dissemination plans

Give brief details of plans for communicating essential messages from the review to the appropriate audiences. Do you intend to publish the review on completion?

Yes

36 Keywords

Give words or phrases that best describe the review. (One word per box, create a new box for each term) Epidemiologycal time series studies

systematic review and meta-analysis

quality assessment

police recommendation

air pollution

health

environmental epidemiology

37 Details of any existing review of the same topic by the same authors

Give details of earlier versions of the systematic review if an update of an existing review is being registered including full bibliographic reference if possible.

Not aplicable

38 Current review status

Review status should be updated when the review is completed and when it is published. Ongoing

39 Any additional information

Provide any further information the review team consider relevant to the registration of the review.

40 Details of final report/publication(s)

This field should be left empty until details of the completed review are available.

Give the full citation for the final report or publication of the systematic review.

Give the URL where available. 


\section{REFERÊNCIAS}

1. Miller BG. Roots of the urban mind. The stress of living with strangers may have spawned cherished aspects of city life. Science. 2016;352(6288): 909-11.

2. Wigginton NS, Fahrenkamp-uppenbrink J, Wible B, Malakoff D. Cities are the future: rapid urbanization is overtaxing the planet, but it may not have to. Science. 2016;352(6288):904-6.

3. United Nations. World Urbanization Prospects: The 2014 Revision, Highlights (ST/ESA/SER.A/352) [on-line]. New York, United. 2014. 32 p. Available from: http://esa.un.org/unpd/wup/Highlights/WUP2014-Highlights.pdf

4. IBGE. Censo 2010 [on-linet]. Available from: http://www.censo2010.ibge.gov.br/sinopse/index.php?dados $=8$

5. Grimm NB, Faeth SH, Golubiewski NE, Redman CL, Wu J, Bai X, et al. Global Change and the Ecology of Cities Global Change and the Ecology of Cities. Science. 2015;319(5864):756-60.

6. Hartig T, Kahan Jr PH. Living in cities, naturally. Science. 2016;352(6288):93640.

7. Mcdonnell MJ, Macgregor-fors I. The ecological future of cities. Science. 2016;352(6288):936-8.

8. C40 Cities. Why Cities ?[on-line]. Available from: http://c40-productionimages.s3.amazonaws.com/fact_sheets/images/5_Why_Cities_Dec_2015.original .pdf?1448476459

9. IPCC5 WGII. Climate Change 2013. 2014.

10. Fajersztajn L, Veras M, Saldiva PHN. Como as cidades podem favorecer ou dificultar a promoção da saúde de seus moradores? Estud Avançados. 2016;30(86):7-27.

11. Fajersztajin L, Alves NDO, Souza M De, Staglionario Z, Veras MM. How can ecological urbanism promote human health? Brazilian J Urban Manag. 2016;8(1):77-95.

12. Nawrot TS, Perez L, Künzli N, Munters E, Nemery B. Public health importance of triggers of myocardial infarction: a comparative risk assessment. Lancet. 2011;377(9767):732-40.

13. Mustafic H, Jabre P, Caussin C, Murad MH, Escolano S, Tafflet M, et al. Main air pollutants and myocardial infarction: a systematic review and meta-analysis. JAMA.. 2012;307(7):713-21.

14. Sobral HR. Heat island in São Paulo, Brazil: Effects on health. Crit Public Health. 2005;15(2):147-56.

15. Berdahl P, Bretz SE. Preliminary survey of the solar reflectance of cool roofing materials. Energy Build. 1997;25(2):149-58.

16. Veras MM, Caldini EG, Dolhnikoff M, Saldiva PHN. Air pollution and effects on reproductive-system functions globally with particular emphasis on the Brazilian population. J Toxicol Environ Heal Part B. 2010;13(1):1-15.

17. Stieb DM, Chen L, Eshoul M, Judek S. Ambient air pollution, birth weight and preterm birth: a systematic review and meta-analysis. Environ Res. 2012;117:100-11.

18. Hamra GB, Guha N, Cohen A, Laden F, Raaschou-Nielsen O, Samet JM, et al. Outdoor particulate matter exposure and lung cancer: a systematic review and meta-analysis. Environ Health Perspect. 2014;122(9):906-11.

19. Guarnieri M, Balmes JR, Francisco S. Outdoor ais polution and asthma. Lancet. 
2014;383(9928):1581-92.

20. Correia AW, Pope III C. The effect of air pollution control on life expectancy in the United States: an analysis of 545 US counties for the period 2000 to 2007. Epidemiol. 2013;24(1):23-31.

21. Wang Y, Eliot MN, Wellenius GA. Short-term changes in ambient particulate matter and risk of stroke: A systematic review and meta-analysis. J Am Heart Assoc. 2014;3(4):1-22.

22. Shah AS V, Lee KK, McAllister DA, Hunter A, Nair H, Whiteley W, et al. Short term exposure to air pollution and stroke: systematic review and meta-analysis. BMJ. 2015;350(h1295):1-10.

23. Atkinson RW, Kang S, Anderson HR, Mills IC, Walton HA. Epidemiological time series studies of PM2.5 and daily mortality and hospital admissions: a systematic review and meta-analysis. Thorax. 2014;69(7):660-5.

24. Cintra M. Os custos dos congestionamentos na cidade de São Paulo. Textos para discussão da Escola de Economia de São Paulo da Fundação Getúlio Vargas. 2014. [on-line]. Available from: http://bibliotecadigital.fgv.br/dspace/handle/10438/11576

25. Saldiva P, Fajersztajn L. Como as cidades moldam a saúde de seus moradores? In. Coleção Sofia Belas Artes. Encontro de Saberes: Artes, Arquitetura, Ciências Sociais e Humanas. São Paulo: Editora Ser Mais; 2015. pg87-98.

26. Kelly FJ, Zhu T. Transport solutions for cleaner air. Science.2016. 352(6288):934-6.

27. Stansfeld SA, Matheson MP. Noise pollution: non-auditory effects on health. British Medical Bulletin. 2003;68:243-57.

28. Stansfeld M, Andersen ZJ, Nordsborg RB, Becker T, TjØnneland A, Overvad K, et al. Long-term exposure to road traffic noise and incident diabetes: a cohort study. Environ Health Perspect. 2013;121(2):217-22.

29. Babisch W. T Traffic noise and cardiovascular disease: epidemiological review and synthesis. Noise Health. 2000;2(8):9-32.

30. CET-Companhia de Engenharia de Tráfego. Acidentes de trânsito fatais em São Paulo - $2014 . \quad$ [on-line]. Available from: http://www.cetsp.com.br/media/395294/relatorioanualacidentesfatais2014.pd

31. Rydin Y, Bleahu A, Davies M, Davila JD, Friel S, di Grandis G, et al. Shaping cities for health: the complexities of planning urban environments in the $21 \mathrm{st}$ century. Lancet. 2012;379(9831):2079-108.

32. Chetty R, Hendren N, Katz LF. The effects of exposure to better neighborhoods on children: new evidence from the Moving to Opportunity Experiment. Am Econ Rev. 2015;106(4):855-902.

33. Chetty R, Hendren N. The effects of exposure to better neighborhoods on children: new evidence from the Moving to Opportunity Experiment. Am Econ Rev. 2015;106(4):855-902.

34. Whitmee S, Haines A, Beyrer C, Boltz F, Capon AG, De Souza Dias BF, et al. Safeguarding human health in the Anthropocene epoch: Report of the Rockefeller Foundation-Lancet Commission on planetary health. Lancet. 2015;386(10007):1973-2028.

35. Woodcock $\mathrm{J}$, The effects of exposure to better neighborhoods on children: new evidence from the Moving to Opportunity Experiment. Am Econ Rev. 2015;106(4):855-902.

36. Woodcock J, Banister D, Edwards P, Prentice AM, Roberts I. Energy and 
transport. Lancet. 2007;370(9592):1078-88.

37. Wilkinson P, Smith KR, Davies M, Adair H, Armstrong BG, Barrett M, et al. Health and Climate Change 1 Public health benefi ts of strategies to reduce greenhouse-gas emissions : household energy. Lancet. 2010;374(9705):1917-29.

38. Wilkinson P, Smith KR, Joffe M, Haines A. A global perspective on energy: health effects and injustices. Lancet. 2007;370(9591):965-78.

39. Dora C, Haines A, Balbus J, Fletcher E, Adair-rohani H, Alabaster G, et al. Indicators linking health and sustainability in the post-2015. Lancet. 2015;385(9965):380-91.

40. Watts Adger WN, Agnolucci P, Blackstock J, Byass P, Cai W, et al. Health and climate change: policy responses to protect public health. Lancet. 2015; 386(106):1861-914.

41. Rao S, Pachauri S, Dentener F, Kinney P, Klimont Z, Riahi K, et al. Better air for better health: forging synergies in policies for energy access, climate change and air pollution. Glob Environ Chang. 2013;23(5):1122-30.

42. Muller NZ. T The design of optimal climate policy with air pollution co-benefits. Resour Energy Econ. 2012;34(4):696-722.

43. Haines A. Health benefits of a low carbon economy. Public Health. 2012;126(SUPPL.1):S33-9.

44. Haines A, Smith KR, Anderson D, Epstein PR, McMichael AJ, Roberts I, et al. Policies for accelerating access to clean energy, improving health, advancing development, and mitigating climate change. Lancet. 2007;370(9594):1264-81.

45. Barton H, Grant M. Urban planning for healthy cities: a review of the progress of the European Healthy Cities Programme. J Urb Heal Bul NY Acad Med. 2011;90:129-41.

46. Brauer M, Freedman G, Frostad J, Donkelaar A Van, Martin R V, Dentener F, et al. Ambient Air Pollution Exposure Estimation for the Global Burden of Disease 2013. Environ. Sci. Technol. 2016,50(1):79-88.

47. Pedersen DB. The Political Epistemology of Science-Based Policy-Making. Society. 2014;51(5):547-51.

48. Choi BCK. Twelve Essentials of Science-based Policy. Prev Chronic Dis. 2005;2(4):1-11. .

49. Lorente DB, Álvarez-herranz A. Economic growth and energy regulation in the environmental Kuznets curve. Environ Sci Pollut Res. 2016. Available from: http://dx.doi.org/10.1007/s11356-016-6773-3.

50. Fiorino DJ. Explaining national environmental performance: approaches , evidence, and implications. Policy Sci. 2011;44:367-89.

51. Kammen DM, Sunter DA. City-integrated renewable energy for urban sustainability. Science. 2016;352(6288):922-8.

52. Globerman S. Global foreign direct investment flows: the role of governance infrastructure. World Development. 2002;30(11):1899-919.

53. Fajersztajn L, Veras M, Barrozo LV, Saldiva P. Air pollution: a potentially modifiable risk factor for lung cancer. Nat Rev Cancer. 2013;13(9):674-8.

54. International Agency for Research on Cancer. Air pollution and cancer. IARC scientific publications n161. 2013. p. 1-171. Available from: https://www.iarc.fr/en/publications/books/sp161/AirPollutionandCancer161.pdf

55. Loomis D, Grosse Y, Lauby-Secretan B, Ghissassi F El, Bouvard V, BenbrahimTallaa L, et al. The carcinogenicity of outdoor air pollution. Lancet Oncol. 2013;14(13):1262-3. 
56. Fajersztajn L, Barrozo L V, Veras M, Guo Y, Coelho MSZS, Saldiva PHN. Improving energetic efficiency in developing economies: oportunities to reduce health inequalities. Conference Proceddeings. $27^{\text {th }}$ Conference of the International Society for Environmental Epidemiology. São Paulo, 30 de agosto a 3 de setembro de 2015. [on-line] Available from: http://www.isee2015.org/programacao/exibe_trabalho.php?id_trabalho=2757\&id atividade $=1077 \&$ tipo $=$

57. Fajersztajn L, Veras M, Barrozo L V, Saldiva P. Air monitoring coverage in lowincome countries: an observational study. Lancet. 2014;384:S14.

58. Veras MM , Costa NSX, Fajersztajn L, Saldiva PHN. Impacts of Air Pollution on Reproductive Health. In: Nadadur SS, Hollingsworth JW. Air Pollution and Health Effects. London: Springer-Verlag London. 2015. p.25-50.

59. Sanderson I. Evaluation, Policy Learning and Evidence-based Policy Making. Public Adm. 2002;80(1):1-22.

60. Woodruff TJ, Sutton P. The navigation guide systematic review methodology: A rigorous and transparent method for translating environmental health science into better health outcomes. Environ Health Perspect. 2014;122(10):1007-14.

61. Woodruff TJ, Sutton P. An evidence-based medicine methodology to bridge the gap between clinical and environmental health sciences. Health Aff. 2011;30(5):931-7.

62. Hartung T. Evidence-based toxicology - the toolbox of validation for the $21 \mathrm{st}$ century? Altex. 2010;27(4):253-63.

63. Kunzli N, Perez L. Evidence based public health - The example of air pollution. Swiss Med Wkly. 2009;139(17-18):242-50.

64. Ranson MK, Bennett SC. Priority setting and health policy and systems research. Health Res Policy Syst. 2009;7:27.

65. Embrett MG, Randall GE. Social determinants of health and health equity policy research: Exploring the use, misuse, and nonuse of policy analysis theory. Soc Sci Med. 2014;108:147-55.

66. Stroup DF. Meta-analysis of observational studies in epidemiology: a proposal for reporting. JAMA. 2000;283(15):2008.

67. Moher D, L Liberati A, Tetzlaff J, Altman DG, Grp P. Preferred reporting items for systematic reviews and meta-analyses: the PRISMA statement. Phys Ther. 2009;89(9):873-80.

68. What is Grade? BMJ Clinical Evidence [on-line]. Available from: http://clinicalevidence.bmj.com/x/set/static/ebm/learn/665072.html

69. Ward V, House A, Hamer S. Developing a framework for transferring knowledge into action: a thematic analysis of the literature. J Heal Serv Res policy Heal Serv Res policy. 2009;14(3):156-64.

70. Cairney P. Standing on the Shoulders of Giants: How Do We Combine the Insights of Multiple Theories in Public Policy Studies? Policy Stud J. 2013;41(1):1-21.

71. Diez Roux A V. Health in cities: is a systems approach needed? Cad saúde pública. 2015;31(1):9-13.

72. Vahlsing C, Smith KR. Global review of national ambient air quality standards for PM(10) and SO(2) (24 h). Air Qual Atmos Health . 2012;5(4):393-9.

73. U.S. Environmental Protection Agency. Office of Air and Radiation. The Benefits and Costs of the Clean Air Act from 1990 to 2020 Final Report. 2011;(April). Available from: http://www2.epa.gov/sites/production/files/2015- 
07/documents/fullreport_rev_a.pdf

74. Luo Y, Chen H, Zhu Q, Peng C, Yang G, Yang Y, et al. Relationship between air pollutants and economic development of the provincial capital cities in China during the past decade. PLoS One. 2014;9(8).

75. Stern DI. The Rise and Fall of the Environmental Kuznets Curve. World Dev. 2004;32(8):1419-39.

76. Sheehan MC, Lam J. Use of systematic review and meta-analysis in environmental health epidemiology: a systematic review and comparison with guidelines. Curr Environ Heal Reports. 2015;2(3):272-83.

77. Stephens ML, Betts K, Beck NB, Cogliano V, Dickersin K, Fitzpatrick S, et al. The Emergence of Systematic Review in Toxicology. Toxicol Sci. 2016;52(1):10-6.

78. Goodwin D. Global Cities. [Group exhibition]. Tate Modern, London, UK.. 2007-06 - 2007-08. [on-line]. Available from: http://discovery.ucl.ac.uk/1317047/ 